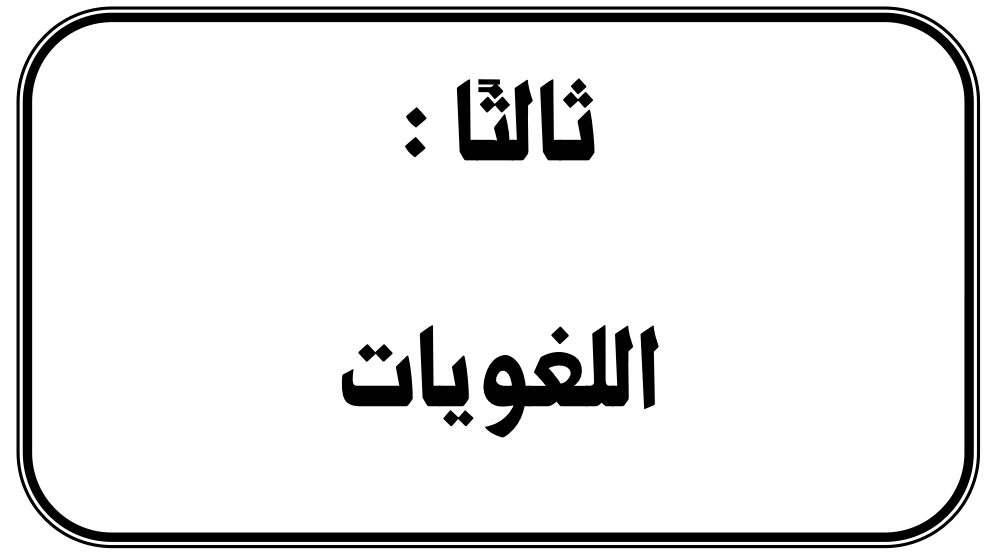





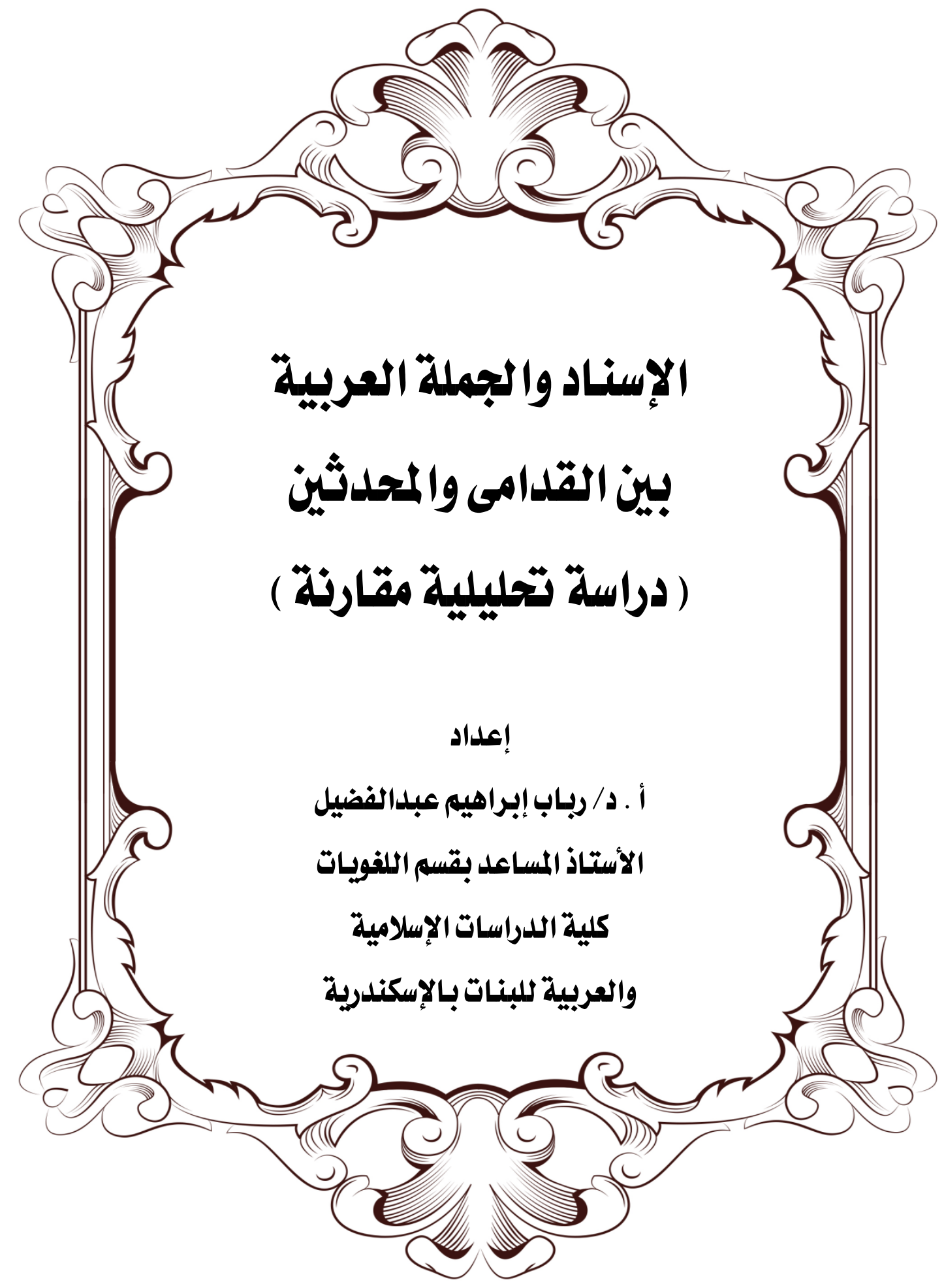





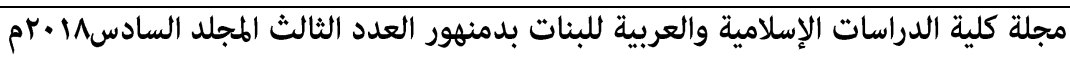

\section{ملخص البحثث}

وضح البحث مفهوم الإسناد في الموروث النحوي حيث يمثل العلاقة القائمسة بين ركني الجملة العربية لتربطهما معا في لحكمه في الجملة الاسمية، فتسند الثاني إلى الأول، فيكون الأول مسندًا إليه والثاني مسندًا في الجملة الاسمية، وذلك من خلال المبتدأ والخبر، أما في الجملة الفعلية فتسند الفعل إلى الفاعل فيكون الأول مسندًا، والثاني مسندًا إليه. أمسا في منظور النحو الحديث فقد تعددت اتجاهـاتهم في تحديد مفهوم الإسـناد فالبعض ثذ يتفق مع القديم الموروث مرة ثم يتراجع الأخرى ليرى أن الضمة علم الإسناد في الجديد تغني عن الإسناد القديم إذ أنه يمثله بفعل الكينونة الذي بات قديمًا مستغنيا عنه، وعليه فيجوز للجملة أن تستغني عن عناصر الإسناد القديمة ويكتفى بعنصر واحد مسندًا كان أو مسند إليه. لـذا فيعترف هـذا ومـن اتبـع مذهبـه بالجملـة ذات الطـرف الواحـده، ومسن ثـم يعترضون على التقدير في الجملة الندائية ونحوها بل أن البعض من هؤلاء يشهد بما يسمى عندهم ابالمركب الفظيه والذي يكتفى فيه بعنصر واحد ولا يرقى لأن يندرج تحت مسمى الجملة فيطلق عليه مسمى 》المركب اللفظي" نحو: (يازيد). بـل يمكن أن يستغنى عن جميع عناصـر الإسـناد لتصـنف التراكيب إلى نوعين تراكيب إسنادية وتراكيب غير إسنادية في منظور هؤلاء. ثم أن الجمل الإسنادية تتحصر في الجمل الاسـية والفعليـة أمـا غير الإسـادية فهي الجملة القسمية وجملة النداء وجملة الإغراء وجملة التحذير وجملة التعجب وجملة المدح والذم ونحوها، وهم بهذا التصنيف الجديد يغضون النظر عن كل ما قدمـه القدامى من اعتبارات بالتأويل والتقدير لا يمـ عندهم إلى الطبيعـة بصلة.

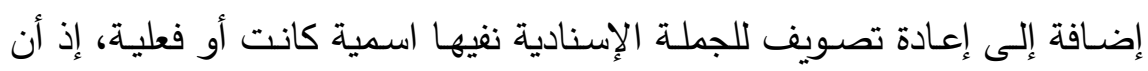
المركب الاسـي يطلق عليه لفظ الجملـة الاسمية- عندهم- متى كان الالمسند اسما《 يدل على 》الدوام والثبوته ومن ثم تتحدد الجملة الفعلية عندهم بأن يكون

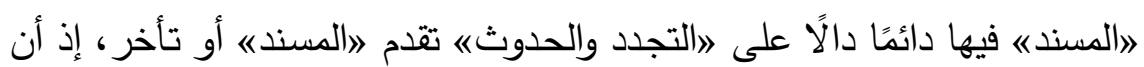




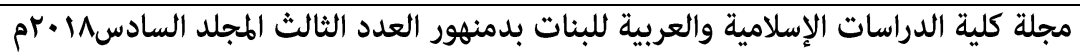
الدلالة على التجدد إنما تستمد من الأفعال وحدها وبهذا التصنيف الجديد يجنبهم التأويل والتقدير وكثير من المشكلات التي أوقع نحاة التراث أنفيهم فيها على حد زعمهم. (1) كمـا أن التركيب الفعلي خضـع لتوجيهاتهم الحديثة حيث رأى البعض إدراج بـاب نائب الفاعل ضــن بـاب الفاعل باعتبار أن المسـد إليه في كل منهمـا (فاعل) فقولك: (كسر الزجاج) مثل قولك انكسر الزجاج، فلم تكد تحس بالفرق بينهما، فكللاهمـا مما لا إرادة لـه، ولا اختيار ، وكلاهمـا ممـا قام بالفعل قيامـا اضـراريا، وكلاهما من وجهة نظر المنطق قد وقع عليه الفعل. إضـافة إلى انسـلاخ التركيب الوصفي من مسمى الجملة الاسمية لإعادة تصنيفه تحت مسمى الجملة الوصفية في منظور النحو الحديث لتميزه وانفراده بخصائص لا يشاركه فيها التركيب الاسمي. كما أن الجملة الثرطية التي بصدق على عنصـريها مسمى جملة الثرط وجملة الجواب تعد تركيبـا مستقلا لا يقبـل الانشطار عند هؤلاء فيسـى العنصـر الأول بلقب العبارة أي عبارة الشرط وفي الثاني بلقب العبارة أيضًا أي: عبارة الجواب، أما مسمى الجملة عندهم فلا يصدق إلا على التركيب كله بمضـام الثاني للأول، أما الجملة الظرفية فتتحرر عند هؤلاء من اعتبارات القدامى من احتمالية كونها من قبيـل الاسـية مـرة ومـن قبيـل الفعليـة مـرة أخرى، ومـن قبيـل الظرفيـة الثالثة ليتخلص التركيب للظرفية بعيدًا عن هذه الاعتبارات. وقد ابدا البحث بالميزان مع الموروث النحوي وجهة نظره والرد على هؤلاء. 


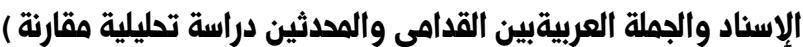

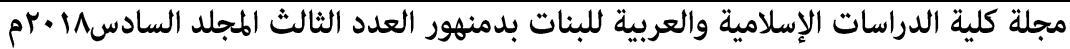

Research Summary

The concept of attribution in modern grammar

And its impact on Arab structures

(In balance)

Preparation

Dr. Rabab Ibrahim Abdel-Fadel

Assistant Professor, Department of Linguistics

Faculty of Islamic Studies

And Arabic for girls in Alexandria

The research shows the concept of attribution in the grammatical heritage, where the relationship between the two corners of the Arabic sentence is represented in the "sentence" in the nominal sentence. The second one is based on the first, The act is based on the actor, so the first one is supported, and the second is dependent on him.

In the perspective of the modern grammar, their directions have varied in defining the concept of attribution. Some tend to agree with the old inherited one time, and then the other retreat to see that the affinity in the new attribution of the old attribution is represented by the being that has become obsolete, and therefore the sentence must give up The elements of the old attribution are limited to one element that was assigned or assigned to it.

Therefore, he admits this and the one who follows his doctrine in the wholesale with the «one party», and then object to the estimate in the sentence and so on, but that some of them testify to what they called «the complex rude», which is enough for one element does not amount to fall under the name of the sentence called the name «Composite verbal» towards: (Yazid).

But can be dispensed with all the elements of attribution to classify the structures into two types of associative structures and non-associative structures in their perspective.

Then, the sentences are limited to the nominal and actual sentences, but the non-synod is the sentence sentence and the total appeal and the whole temptation and the total warning and the total exclamation and the whole praise and slander 


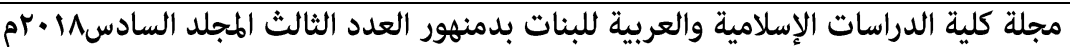
and so on, they are this new classification, regardless of all the old considerations of interpretation and appreciation does not belong to nature. In addition to the re-spacing of the reference sentence, its nominal or actual negation, since the nominal compound is called the term "nominal sentence" - when "the noun" signifies "permanence and certainty" and then the actual sentence is determined to have "predicate" On the «renewal and occurrence» progress «Almmsn» or delayed, as the sign of renewal is derived from the acts

Alone, and this new classification avoids interpretation and appreciation and many of the problems that caused the heritage of the Prophet Nfihm where they claim.

And the actual structure has been subject to their modern directions, where some saw the inclusion of the door of the deputy actor within the door of the actor as the assignee in each of them (actor), saying: (breaking glass) such as saying broken glass, did not feel the difference between them, Neither choice, both of which have already been made necessary, both from the point of view of logic that the act has already occurred.

In addition to the descriptive structure of the descriptive name of the nominal sentence to be reclassified under the descriptive sentence in the perspective of the modern grammar to distinguish it and singled out characteristics that are not shared by the nominal structure.

The sentence sentence, which is true to its two elements, is called the sentence clause, and the sentence of the answer is an independent form that does not accept fission. The first element is called the term " Second, the circumstantial sentence is liberated in these considerations from the old possibility of being a nominal once and again like the actual, and the third circumstance to remove the structure of circumstantial away from these considerations.

He has never looked at the balance with his grammatical point of view and responded to these. 
الإسناد والجملة العربيةبين القدامى والهددثين دراسة تحليلية مقارنة )

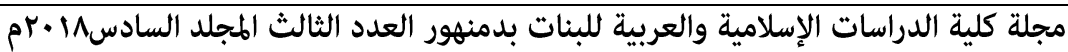

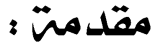

الحمـد لله أن أكرمنـا لأفصـح بيـان، وخلد العربيـة بـالقرآن. والصـلاة والسـلام علـى خيـر الأنـام، سـيدنا وحبينــا محمد الأمسين، خـاتم الأنبيـاء والمرسلين.

وبعد 666

فقد دعاخي إلى هذه الد راسنّ:

قيمـة الجملـة وعلاقتها بالنحو، إذ أن الالجملـة هـي الغايـة الأولى لكل

نظام نحوي، حيث أن النظام النحوي يعمل على كشف تركيبها، ويحاول أن يربط بين الصورة الصوتية المنطوقة لها؛ والمعنى المراد منها من خلال النظام

$$
\text { العقلي الذي يحكمهای ('). }
$$

وأن ثــة التفاعل بـين الوظيفـة النحويـة والدلالـة المعجميـة للمفرد الذي

يثخل هذه الوظيفة، ويشكل هذا التفاعل بينهما مـع الموقف المعين - المعنى الدلالي للجملة كلها.

فالجملـة جديرة بالدراسـة، وهي مسن الموضـوعات التي تثقل الباحـ، وتمكنه من تخصصسه، إذ أنها محط أنظار علمـاء النحو القدامى، والمحدثين العرب، والغرب على السواء.

أما عن معنى الإسناد في اللغنت: فيقال: سند الثيء سندًا؛ جعل لله

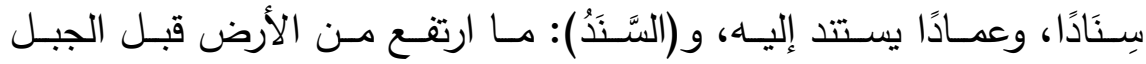
أو الـوادي. وأسـندت الثـيء: سـنده، وسـاندت الرجل مسـاندة: إذا عاضـدته ولهـ

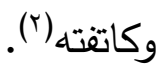

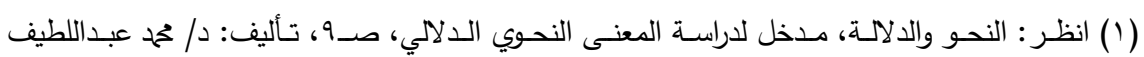

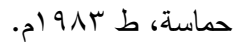

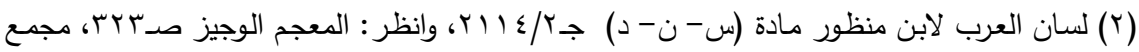

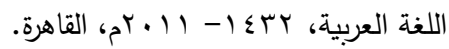


الإسناد والجملة العربيةبين القدامى والمحدثين دراسة تحليلية هقارنة )

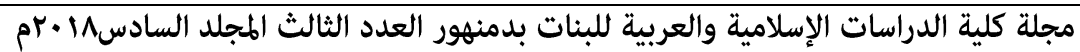

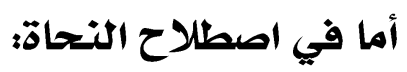

فيقول الخليل:

الكـلام سَـندُ ومُسنـندّ، فالسَّنَدُ كقولك: (عبدالله رجل صـالح)، ف (عبدالله)

$$
\text { سَنَدُ و (رجل صالح) مسند إليهه ('). }
$$

وعلى ذلك يتبين لنا أن المراد بالإسـاد هو: وجود طرفين في الكـلام

حتى يحسن السكوت عليه، بل أن الكلام المفيد ما تضمن تركيبا إسناديًا مكون من عنصـرين أو عضدين أحدهما يسمى السند (أي المسند إليه) وهو الاسم عبدالله المبتدأ به، والآخر يسمى بالمسند وهو: رجل صالح المخبر به.

\section{أما في النحو الدحليث:}

فقد ظهر مخـالفتهم للمـوروث النحـوي في مفهوم الإسـناد وذلك لعـدة

اعتبارات من بينها:

إعادتهم تقسيم الكلمة العربية من جهة، ومن جهة أخرى خروجهم على بلى المألوف في مفهوم الإسناد وكان لهذا وذاك أثره على التراكيب العربية الأمر الذي دعاني إلى لاوضع الميزانه في هذه الدراسـة، لفرز مـا شاع عنهم إيجابا وسلبا وبيان غثه من سمينه حتى لا يتاح لهم تبوُّؤ مكانة غير مستحقة، اللهم عن استحقاق فليكن وليشهد البحث بهذا أو تلك منصفًا محايدًا ملتزمًا بالأمانة مانة العلمية. لذلك كان عقد الميزان أمامهم ابالموروث النحويه في مقابل آرائهم

$$
\text { سواء في: }
$$

1- تحديد مفهوم الإسناد الذي طالما لاصق تحديد مفهوم الجملة العربية.

$$
\text { r- أو في الأثر الذي اجتاح التراكيب العربية. }
$$

وقد أتيت قبل هذا وذاك بتمهيد يوضـح علاقة الجملة أو الكلام باللغـة

من خـلال تعريـف اللغـة، والفرق بينها وبين الجملة أو الكلام نظرًا للارتباط

القريب بينهم.

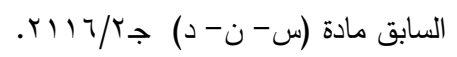


الإسناد والجملة العربيةبين القدامى والهحدثين دراسة تحليلية مقارنة )

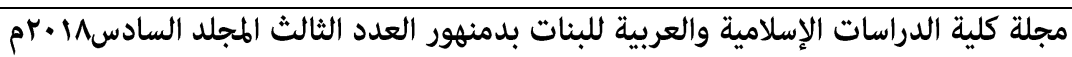
وللوصول إلى الغاية التي يهدف إليها البحث- اقتضت الخطة أن تكون على النحو التالي: - ملى الاقدمهة: وفيها: أسباب ودوافع اختيار البحث والهدف منه. التمههيد: ويوضح أمرين: ا - تعريف اللغة. r- الفرق بين اللغة والجملة (الكلام). ثم قسمت البحث إلى أربعة فصول. الفصل الأول: تعريف الجملة في الموروث النحوي والعلاقة بينها وبين الكلام. الفصل الثاني: مفهوم الإسناد في الموروث النحوي، وعلاقته بالجملة. الفصل الثالث: مفهوم الإسناد في النحو الحديث وعلاقته بالجملة. الفصـل الرابـه: أثر الإسناد في النحو الحديث على التراكيب العربية في الميزان.

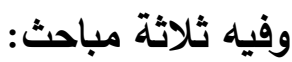
المبـحث الأول: أثره على التقسيم الثنائي القديم. المبحث الثاذي: أثره على الجملة الثرطية والجملة الظرفية. المبحث الثالث: أثره على التركيب الوصفي. ثم الخاتمة: وفيها أهم النتائج. ثم ثبـت المسادر والمراجع. ثم الفهارس الفنيسة. 
الإسناد والجملة العربيةبين القدامى والمددثين دراسة تحليلية مقارنة )

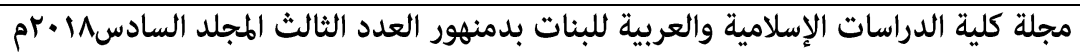

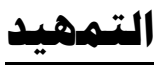

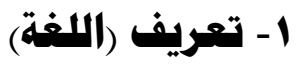

فقد عرفها ابن جني في القرن الرابع الهجري حيث قال: 》أما

حدها فإنها أصوات يعبر بها كل قوم عن أغراضهمهي" (1).

أما ابن سنان الخماجي فقال في القرن الخامس الهجري في تعريفها:

》عبارة عما يتواضع القوم عليه من الكلامي"(r).

وفي هذا التعريف إضـافة، حيث أثار جدلًا حول نشأة اللغة، وهل هي

إلهام، أو اصطلاح؟ حيث انقسم العلمـاء إلى فريقين أحسلهما يقول: بأنها

إلهام من الله فهي توقيفية.

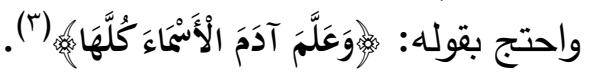

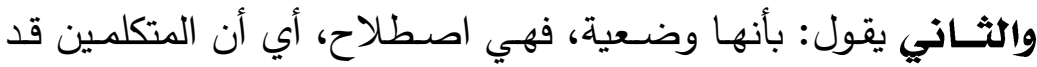

اتفقوا واصطلحوا على تسمية كل شيء باسم ما.

ورجح ابن سنان أنها وضعية، اصطلاحية، كلامية. أي تتحقق بالفعل

اللساني، كما أنها تأتي بفعل الأقوام لها فهي اجتماعية(ع).

أما ابن خلد ون (ت 1+1هـ) فعرفها بقوله:

》اللغـة في المتعـارف عبارة المـكلم عن المقصـود، وتلك العبارة فعل

لسانيّ ناشئة عن القصد لإفادة الكلام، فلابدّ أن تصير ملكة متقرّة في العضو

الفاعل لها وهو اللّسان، وهو في كلّ أمّة بحسب اصطلاحاتهمه (0).

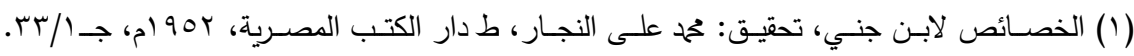

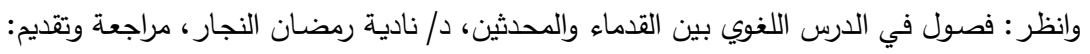

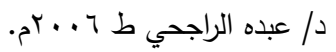

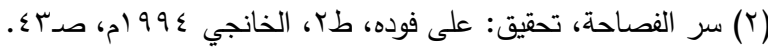

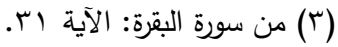

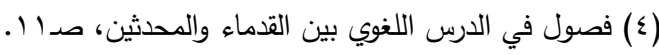

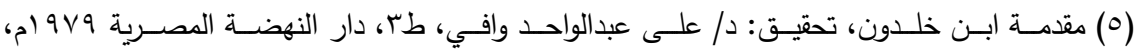

$$
\text { . } 11 \text { T }
$$




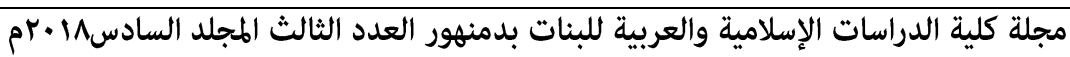
فقد وضـح مـن هذا التعريـف أن ابن خلدون قد أدرك أن اللغـة وسـيلة تعبير للمتكلم عما يريد أن يعبر عنه، وأنها ملكة مكتسبة يتلقها المتكلم من فن بيئته المحيطة به فيتعلمها. فهي إذن عنده مكتسبة بطريق الدربـة والممارسـة كمـا أنها فعل لسـاني قائم على المشافهة.

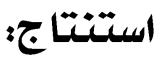
يلاحظ مـن خـلال العرض لتعريف اللغـة عند علمـاء العـرب وعلمـاء الغرب أن المختار تعريف ابن جني على أنها: 》أصوات يعبر بها كل قوم عن أغراضههي فهي إذن (أصوات منطوقة) وهذا يفسر لنا أن الأوائل عرفوا اللغة سماعا قبل رؤيتها رموزًا مصورة، ومن ثم يتبين لنا اهتمامهم بالرواية والسماع والمشافهة في جمع اللغتة وكذلك اهتمامهم بعلم القراءات وعلم التجويد. فقد اتفق هذا التعريف مـع ما أتى بـه علمـاء الغرب من تحديدهم للغـة على أنها رموز صوتية أو علامات رمزية ذات دلالة معينة. ومن عناصر اللغة أيضًا عند ابن جني أنها: (يعبر بها)، وهي بذلك أوماه وسيلة حياة يعبر بها كل جماعـة من الناس عن أغراضـهم واحتياجاتهم وهذه وظيفة اللغـة كما وضـحها فريق من المحدثين الغربيين حيث ذكر أحدهم أن اللغة وسيلة إنسانية غير غريزيـة لتوصيل العواطف والأفكار والرغبات بنظام

$$
\text { من الرموز الاصطلاحية('). }
$$

مدـا يبـرهن علـى وعـي علمــاء العربيــة بوظيفــة اللغــة، وارتباطهـا

$$
\text { بالمجتمعات على الرغم من اختلاف أصواتها من مجتمع إلى آخر • }
$$
أما العنصر الأخير في تعريف ابن جني أنها (أغراض) فهذا يعد تعريف جامع لكل وظائف اللغة كما ذكر المحدثون. 


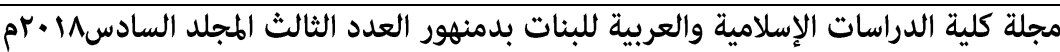
ولذ لهك قال عنه أحلد الباحثين:

״كان موفقا في اختياره؛ حيث جاء جامعًا مانعًا لتعريف اللغة ووظيفتها؛

ومن ثم كان هذا التعريف مستتبطًا من داخل اللغة وليس من خارجهاه (').

\section{r- الفرق بين اللغة والبمهلة}

فقد حدد الدكتور تمام حسان الفرق بين اللغة والجملة في إطار تعريف

اللغة العربية الفصحى 》أبها مجموعة من الأنظمة والعلاقاتش(؟).

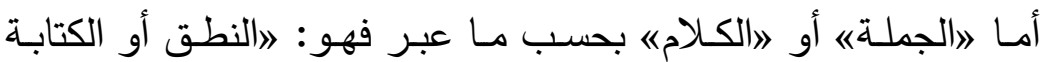

$$
\text { بحسب قواعد هذه الأنظمة والعلاقاته (r). }
$$

والأنظمة المعني بها عنده هي: النظام الصوتي والنظام الصرفي والنظام

النحوي للغة.

ويني الدكتور تمام حسان على هذين التعريفين الفروق بين كلٍ منهما: فيقول: افـالكلام عمل واللغـة حدود هذا العمل، والكـلام سـوك واللغـة معايير هذا السلوك، والكـلام نشـاط واللغـة قواعد هذا النشـاط، والكـلام حركة واللغة نظام هذه الحركة، والكلام يحس بالسمع نطقًا والبصر كتابة واللغة تفهم بالتأمل في الكـلام. فالذي نقوله أو نكتبه كلام، والذي نقول بحسبه ونكتب بحسبه هو اللغة، فالكلام هو المنطوق وهو المكتوب، واللغة هي الموصوفة في كتب القواعد وفقـه اللغـة والمعجم ونحوهـا. والكـلام قد يحدث أن يكون عملًَ فرديًّا، ولكن اللغة لا تكون إلا اجتماعيةه(؛).

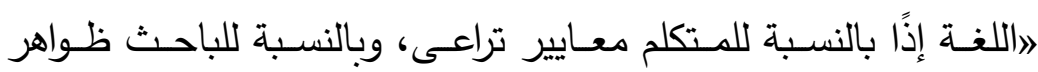
تلاحظ، وهي بالنسبة للمتكلم ميدان حركة، وبالنسبة للباحث موضوع دراسـة،

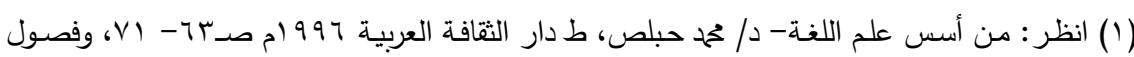
في الدرس اللغوي بين القدماء والمحدثين.

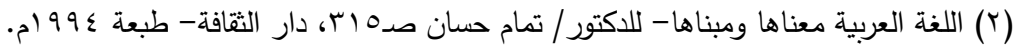




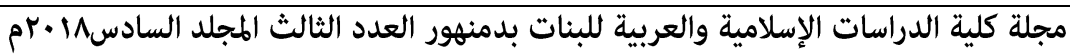

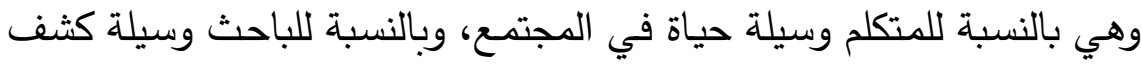

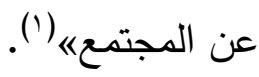

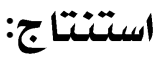

تبـين أن: (اللغـة) مجموعـة مـن الأنظمـة والعلاقـات، بينمـا (الجمـل) أو (الكلام) هو النطق أو الكتابة بحسب قواعد هذه الأنظمة والعلاقات. فالعلاقة إذًا بينهما تبدو لزومية، إذ أن اللغة تتمثل في النظام الصسوتي، والنظام الصـرفي، والنظام النحوي مدا يلزم عند صـوغ الجمل والعبارات. أمـا الكلام فأن ينطق، أو يكتب بحسب قواعد هذه الأنظمة والعلاقات.

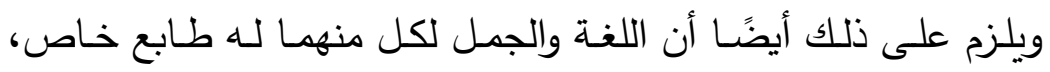

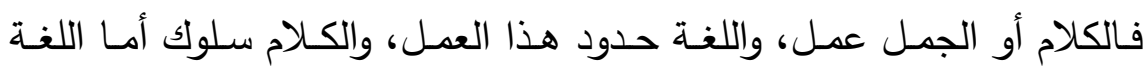
فمعايير هذا السلوك، والكلام نشاط واللغة قواعد هذا النشاط، والكلام حركة، واللغة نظام هذه الحركة، والكلام يحس بالسمع نطقا والبصر كتابة، بينمـا اللغة تفهم بالتأمل في الكلام.

فالذي نقوله أو نكتبه كلام، والذي نقوله بحسبه ونكتب بحسبه هو اللغة. فالكلام هو المنطوق وهو المكتوب، واللغـة هي الموصـوفة في كتب القواعد وفقه اللغة، والمعجم ونحوها، والكلام قد يكون عملا فرديا، ولكن اللغة لا تكون إلا اجتماعية.

إذًا اللغة بالنسبة للمتكلم معايير تراعى، وبالنسبة للباحث ظواهر تلاحظ، وهي بالنسبة للمـتكلم ميدان حركـة، وبالنسبة للباحث موضـوع دراسـة، وهي بالنسبة للمتكلم وسيلة حياة في المجتمع، وبالنسبة للباحث وسيلة كثف عن المجتمـع، وهو مـا أشـار إليه سيبويه النحو في العصر الحديث الدكتور تمـام حسان.

\section{ल2खिध}


الإسناد والجملة العربيةبين القدامى والهحدثين دراسة تحليلية مقارنة )

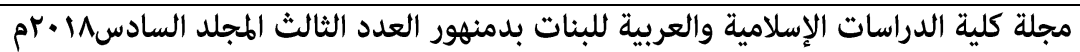

\section{الفصل الأول}

\section{تعريف البمملة في الموروث النهوي}

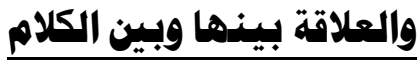

فقد جاء في باب الاستقامة من الكـلام والإحالة حديث سيبويه عـن: الكـالامر: بأنـه مـا تـوفر فيـه معياران: التمـام التركيبي والإفـادة في المعنى والدلالة. فإذا وجد هذان المعياران سـي ذلك الثـيء كلامـا. إذ يقول: الفمنه مستقيم حسنٌ، ومحال، ومستقيم كذب، ومستقيم قبيح، وما هو محال كذب. فأما المستقيم الحسن فقولك: آتيتك أمس وسآتيك غدًا ('). أما الجملش: فلا نستطيع أن نقف عنده على استعمال هذا المصطلح في كتابه على الإطلاق.

وإنما بدأ ظهوره مع المبرد إذ يقول في المقتضب: اوإنما كان الفاعل رفعا لأنه هو والفعل جملة يحسن عليها السكوت، وتجب بها الفائدة للمخاطب. فالفاعل، والفعل بمنزلـة الابتداء، والخبر ، إذا قلت: قام زيد، فهو بمنزلة قولك: القائمُ زيدٌه (؟). فنرى أن الجملة عنده هي التي تكونت من فعل وفاعل أو مبتدأ وخبر

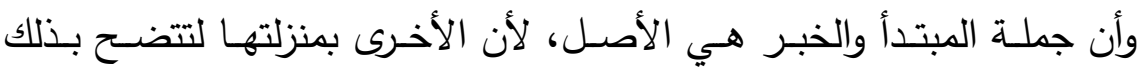
مكونات الجملة العربية. ويقول في باب المسند والمسند إليه:

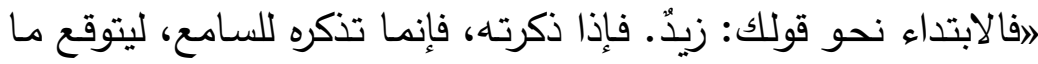
تخبره بـه عنه، فإذا قلت (منطلقُّ) أو ما أشبهه - صـح معنى الكلام. وكانت الفائدة للسامع في الخبره (). 


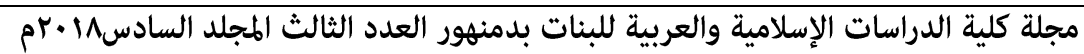

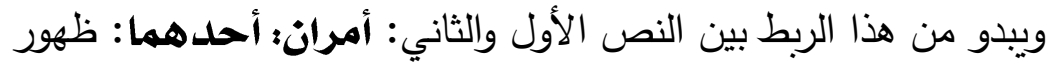
التركيب الإسنادي في الجمل التي مثل بها المبرد حيث ساق التعريف تحت باب المسند والمسند إليه.

والثاذي: أنه سوّى بين الكلام والجملة. وأنهما عنده مترادفان.

\section{ورأي ابن جني، أخهما مترادفان إذ يقول:}

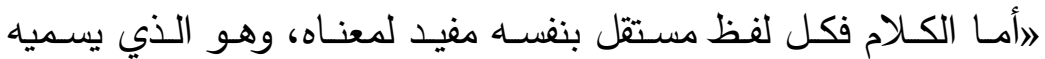

النحويون الجمل نحو: زيد أخوك، وقام حمح، وضرب سعيده (').

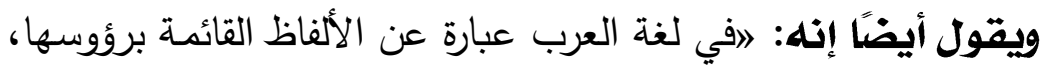

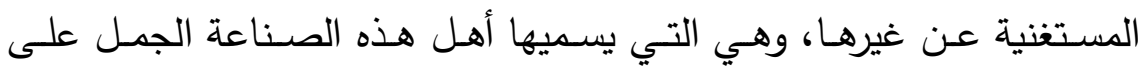
اختلاف تراكيبهای) (r).

وأمـا الأمثلـة فقد أتى بمجموعـة مـن التراكيب المختلفـة، كل لفظ منهـا استقل، بنفسـه وظهر معنـاه، ليمثل بـه على كونـه كلامًا ويسـي عنده أيضًا بالجملة نحو: قام ححم، وضُربَ سعيدٌ- وفي الدار أبوك، وصهه ومه ورويدَ وحاءِ

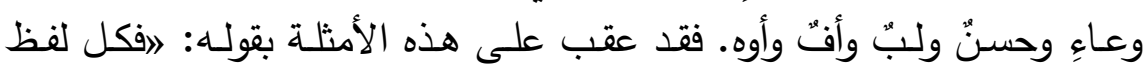

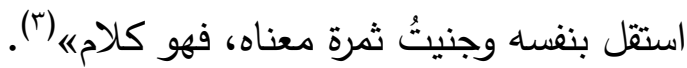

يلاحظ من نص ابن جني في تمثيله للكـلام والجمل أنـه أتى بأمثلة متنوعة من التراكيب فهناك الجملة الفعلية المبنية للمعلوم نحو قام خحم وهناك المبنيـة للمفعـول نحـو: ضُـرب سـعيدٌ وهنـالك الجملـة الظرفيـة المصـدرة بجـار ومجرور في نحو قوله في الدار أبوك، وهناك الجملة المكونـة من اسم فعل وكل هذه التراكيب تتساوى في إطلاق لفظ الكلام عليها أو الجملة. وقد فصل مذهبه هذا حين قال: االكلام جنس للجمل. فإذا قال: قام محهد، فهو كلام. وإذا قال: قام محمد وأخوك جعفر، فهو أيضًا كلام، كما كان لما هـا وقع على الجملة الواحدة كلاما ......

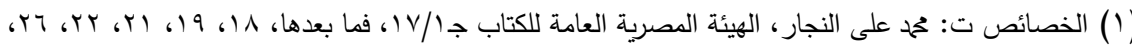


الإسناد والجملة العربيةبين القدامى والمددثين دراسة تحليلية مقارنة )

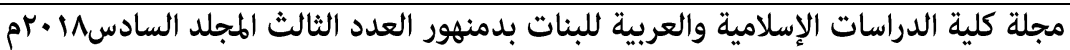
كذذلك رادف بين الكالاه والجملت عبد القاهر فقال: العلم أن الواحد من الاسم والفعل والحرف يسمى كلمة، فإذا ائتلف منها اثنان فأفادا

$$
\text { نحو: خرجَ زيٌّ، سمي كلامًا، وسمي جملةه ('). }
$$

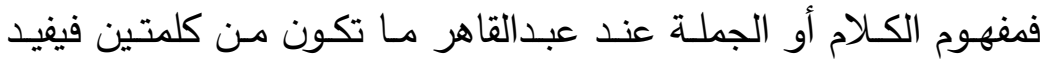

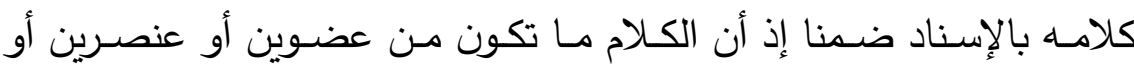
كلمتين.

أمـا الزمخشـري فقد صـرح بالإسـناد بقولـه: 》الكـلام هـو المركب مـن كلمتين، أسندت إحداهما إلى الأخرى، وهذا لا يأتي إلا في اسمين - كقولك: زيد أخوك، وبشر صاحبك- أو في فعل واسم نحو - قولك: ضرب زيد، وانطلق بكر - وتسمى الجملةه (r). فظاهر قوله أن الكلام يرادف الجملة وأنه مشروط بالإسناد.

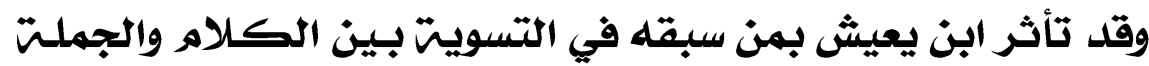

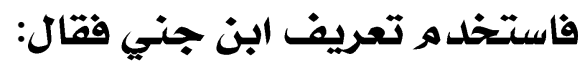
ااعلم أن الكلام عند النحوين عبارة عن لفظ مستقل بنفسه مفيد لمعناه ويسمى الجملة نحو: زيد أخوك وقام بكر وهذا معنى قول صساحب الكتاب: المركب من كلمتين أسندت إحداهما إلى الأخرى فقد اقتدى ابن يعيش بتعريف ابن جني، وطبق على أمثلة الزمخثري مشيرًا إلى الإسناد الذي نص عليه الزمخشري والذي توفر في كل جملة مستند إليها حيث وجدت مكوناته، ثم جاء مرة أخرى بتعريف مستقل لله موحدًا الكلام والجملة أيضًّا فقال: اوممـا يسأل عنـه هنـا الفرق بين الكـلام والقول والكلم. والجواب أن الكلام: عبارة عن الجمل المفيدة وهو جنس لها، فكل واحدة من الجمل الفعلية والاسمية نوع لله يصدق اطلاقه عليهاه (ع).

\section{crcessen}

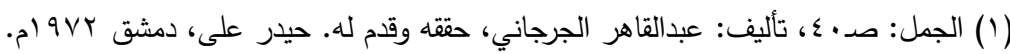

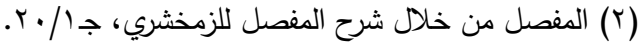

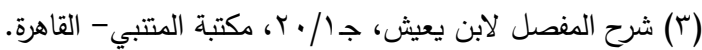

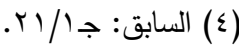


الإسناد والجملة العربيةبين القدامى والمددثين دراسة تحليلية مقارنة )

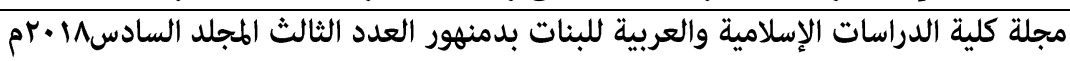

\section{|النمال الثاني}

\section{هفهوم الإسناد في الموروث النصوي}

\section{وعلاقته بالبمهابة}

ارتبط الإسـناد بالتراكيـب العربيـت حيـث اخـتص ابـن التحاجب الكالامر بالإسناد فقال: الحساد

״الكـلام مـا تضـمن كلمتين بالإسناد، ولا يتأتى ذلك إلا في اسمين، أو

في فعل واسم" (') - (1)

ويشرح الرضي اوالمراد بالإسناد: أن يُخبر في الحال أو في الأصل بكلمة أو أكثر عن أخرى، على أن يكون المخبر عنه أهم مما يخبر عنه بذلك اله الخبر في الذكر وأخص بهی(r).

ليشـهل ذحهو: قام زيد، وزيد قائم، وبعت، وأنت حرّ ، وهل أنت قائم،

وليتلك ولعلك قائم، واضرب، وإليهم أيضًا نحو: زيد أبوه قائم، وزيد قائم أبوه.

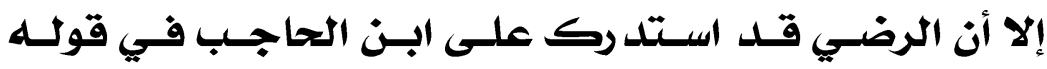

(بالإسناد) المطلق فقال: كان عليه أن يقيده بالإسناد الأصلي، المقصود مـا تركب بـه لذاته، ليخرج بالأصـلي إسناد المصدر واسـي الفاعل والمفعول والصـفة المشـهة والظرف، فإنها مـع مـا أسـندت إليـه ليسـت بكـلام (r). لأنهـا مفردات فقدت الإسناد الجملي وإن كان أوصاف تدل على ذات إلا أنها ليست بتركيب جملي أو كلامي، وأما نحو: أقائم الزيدان، لكونه بمنزلة الفعل وبمعناه، كما في أسـاء الأفعـال: فهي عنده جملة وليست كـلام إذ أنها خرجت مـن تركيبها الأصلي بالإسناد الجملي حيث اعتمدت على ما يقربها من عمل الفعل الإن حيث أسندت إلى فاعل سد مسد الخبر فصارت جملة.

$$
\begin{aligned}
& \text { (1) الكافية في شرح الكافية للرضي جا / آم. تصحيح: يوسف حسن عمر - مؤسسة الصادق - طهران. }
\end{aligned}
$$

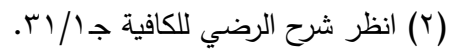

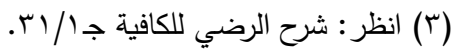


الإسناد والجملة العربيةبين القدامى والمددثين دراسة تحليلية مقارنة )

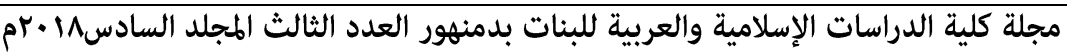

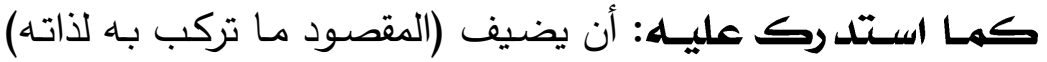
ليخرج الإسـاد الذي في خبر المبتدأ في الحال أو في الأصلـ، وفي الصفة والحال، المضاف إليه إذا كانت كلها جملًا.

وعلى ذلكك يكون الرضي قل خالف من سبقه من النحاة في أخهـ

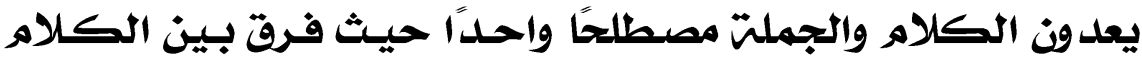
والجملن فقال

اوالفرق بين الجملة والكلام، أن الجملة ما تضمن الإسناد الأصلي سواء كانت مقصودة لذاتها أو، لا، كالجملة التي هي خبر المبتدأ وسائر ما ذكر من

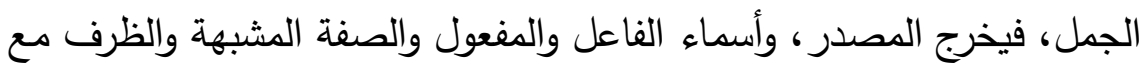
ما أسندت إليه.

والكـلام: مـا تضـمن الإسـناد الأصلـي، وكان مقصـودًا لذاته، فكل كـلام

$$
\text { جملة ولا ينعكس" (1) }
$$

فالرضـي يلتزم بالإسـناد سـواء أكـان في الجملـة أو في الكـلام ولـيس الإسناد المطلق بل الإسناد الأصلي الذي هو رابطة ولابد له من طرفين مسند ومسند إليه. فيحترز بذلك عن بعض ما ركب من اسمين كالمضاف والمضاف إليـه والتابع والمتبـوع وبعض المركب مـن الفعل والاسـم نحو: ضَـرَتَكَ، وعن جميع الأنواع الأربعة الأخر من التركيبات الثنائية الممكنة بين الكلم الثلاث، وهي اسم مع حرف، وفعل مع فعل، أو حرف، وحرف مع حرف. فأحد أجزاء الكلام هو الحكم. أي الإسناد. الذي هو رابطة كما ذكرنا، ولابد لله من طرفين المسند والمسند إليه والاسم بحسب الوضع يصلح لأن يكون

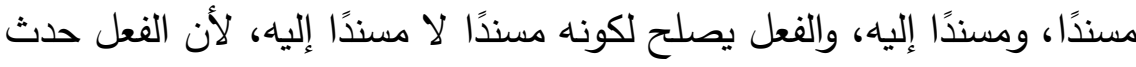
والحدث متغير والفعل يتغير فيخبر به ولا يخبر عنه، أما الاسم فثابت فيصلح للحكم باه أو الحكم عليه والحرف لا يصلح لأحدهما.

وذكر الرضـي بذلك أن التركيب العقلي الثنائي بين الثاثثة أشياء أي: الاسم والفعل والحرف، لا يعدو ستة أقسام:

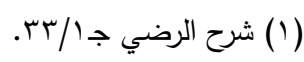




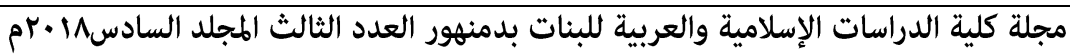

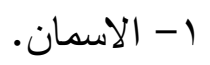

r- الاسم مع الفعل أو الحرف.

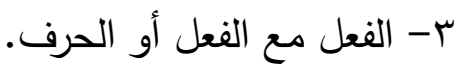

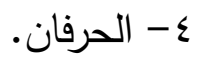

فالاسمان يكونان كلامًا، لكون أحدهما مسندًا والآخر مسند إليه، وكذا

الاسم مع الفعل لكون الفعل مسندًا والاسم مسندًا إليه.

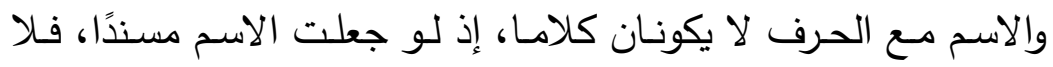

مسند إليه، ولو جعلته مسندًا إليه فلا مسند، وأمسا نحو: يازيد ف لسدِّ "يـا" مسدِّ

$$
\text { (دعوت) مرادًا به الإنشاء. }
$$

والفعـل مـع الفعـل أو الحـرف لا يكـون كلامَّا لعـدم المسـند إليـه، وأمـا

$$
\text { الحرف مع الحرف فلا مسند فيهما ولا مسند إليه('). }
$$

أما ابن هشامر فتأثر بالرضي في أذهما ذيس بمترادفين، واعتبر

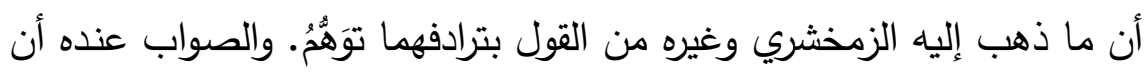

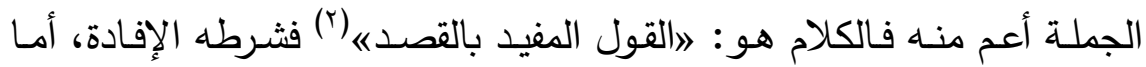
الجملة فعبارة عن: الفعل وفاعله كـ قام زيد، والمبتدأ وخبره 》كزيد قائمه وما ليا

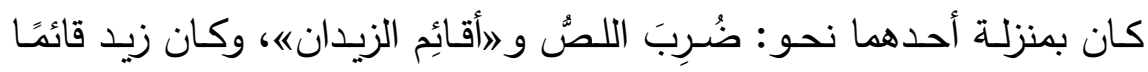
وظننته قائما، فبان الفرق بينهما ولهذا تسمعهم يقولون: جملة الشرط، جملة الجواب، جملة الصلة. وكل ذلك ليس مفيدًا فليس

بكلام.

فيعرف ابن هشام الجملة على أساس تركيبي فيرى أنها تركيب إسنادي

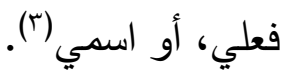

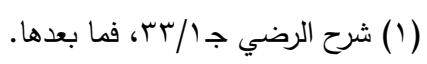

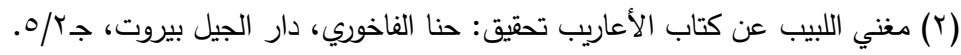

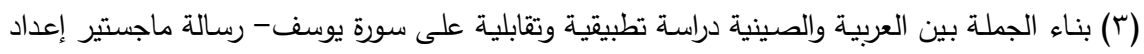

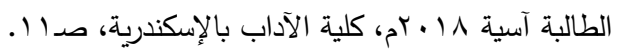


الإسناد والجملة العربيةبين القدامى والهحدثين دراسة تحليلية مقارنة )

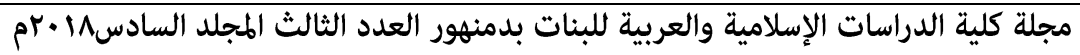

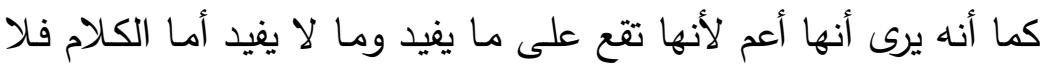
يوضـح إلا فيما يفيد.

ويوافقه السيوطي في أن الجملش أعـه من الكـلامر، ولا ترادفه،

لعدم توفر شرط الإفادة فيها (').

فالكلام عنده قول مفيد، والمراد بالمفيد مـا يفهم معنى يحسن السكوت

عليه. وهل المراد سكوت المتكلم أو السامع، أو هما؟ أقوال. الراجح أنه الأول (المتكلم)، لأنـه خـلاف التكلم، فكمـا أن التكلم صفة المتكلم، كذلك السكوت صفته أيضًا(r). والمراد بـ (حسن السكوت عليه): ألا يكون محتاجا في إفادته للـمامع النتيججن:

ا- اتصففت الجملـة العربيـة منذ نشـأتها الأولى والتهي رودفت فيها بمسـى 》الكلامه أنها مركبة تركيبا إسناديًا يشهد بذلك عبارة الخليل ابن أحمد في

$$
\text { تعريفه للإسناد فالكلام عنده (سند ومسند). }
$$

r- توالي الكثف عن التركيب الإسنادي للجملة العربية من خلال تعريفات النحاة عند مرادفة مسماها بمسمى الكلام حيث يرصدها المبرد في باب المسـند والمسـند إليـه ليكثف بذلك عن عنصسرين أساسين يتكون فيهما التركيب الجملي الإسنادي والتي يتضدن كلمتين يحسن السكوت عليها. سواء كانت هاتين الكلمتين مصدرة بفعل مـع فاعل أو مبتدأ مـع خبر إذ أن الأولى بمنزلـة الثانيـة أي أن المصدرة بالمبتدأ أصـل للمصدرة بالفعل هل

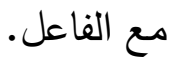

ب- يعطي ابن جني نماذج متعددة لصور الجملة العربية والتي ترادف الكلام فمنها الفعلية المصدرة بفعل مبني للمعلوم ومنها الفعلية المصدرة بغعل 


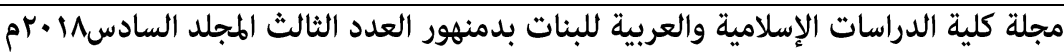
مبني للمفعول ومنهـا الظرفيـة المصـدرة بجر ومجـرور ومنهـا المصـدرة بأسماء الأفعال وأسـاء الأصـوات لتضـع كل هذه التراكيب تحت مسمى الجملة العربية والتي سميت واتصفت بالأسـس بالإسناد وهذا أمرُ ينبئ عن أن جميع الجمل العربية تصصب تحت مركب واحد مسماه التركيب الإسنادي ولا شيء سواه حيث جعل الأصناف كلها تحت مسمى الجملة أو الكلام.

ـ- يتفق النحـاة على أن الكـلام مـا تكـون مـن كلمتين وأفـاد ويســى أيضًــا بالجملة ومفاد ذلك أمران: أ- لتسوية بين مسمى الجملة والكلام. ب- اشتراط الإسناد ضمنا حيث توافر ركني الإسناد وذلك عند عبدالقاهر . ه- يعـد الزمخشـري أول مـن صـرح بالإســناد إذ أن الكـلام عنـده أو الجملـة

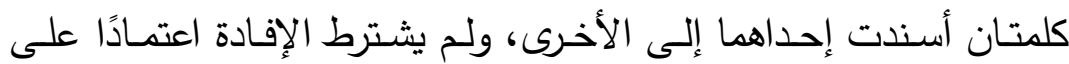
فهمها من النماذج التي مثل بها نحو: زيد أخوك، بشر صـاحبك، ضرب الترك زيد، انطلق بكر • فقد يكون التركيب مكون من اسمين أو من فعل واسم على ما هو واضح بالأمثلة. ج- اقتدى ابن يعيش بابن جني في تعريفه للكلام أو الجملة حيث رادف بينهما إلا أنه طبق تعريفه على أمثلة الزمخشري مشيرًا إلى الإسناد الذي نص عليه الزمخثري في تعريفه. V- اختص ابـن الحاجـب الكـلام بالإسـناد لتتميـز الجملـة العربيـة الإسـنادية بالعنصر 》الثالث « لمكوناتها وهو الإسناد. ^- انفراد الرضي بمخالفة من سبقه في التفرقة بين مصطلحي الكلام والجملة. فالجملة عنده ما تضمن الإسناد الأصلي سواء كانت مقصودة لذاتها أو لا كالجملـة التي هي خبر المبتدأ نحو: زيد قائم، أو غيرهـا، نحو: قام زيــ وبعت، وأنت حر ، وهل أنت قائم، وليتك، ولعلك قائم، واضرب، ونحو: زيد أبوه قائم، وزيد قائم أبوه. 


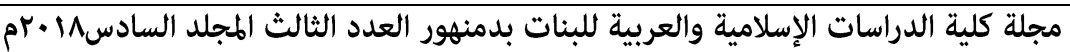
فيخرج المصدر واسم الفاعل والمفعول والصفة المشبهة والظرف مـع ما أسندت إليه. لأن كل هذا ليس إسنادًا أصليا. وأمـا الكـلام فهو مـا تضـمن الإسـناد الأصـلي وكان مقصـدًا لذاته فكل كلام جملة وليس كل جملة كلامًا. 9- يفسر الرضي عنصر الإسناد أو مكون الإسناد ثالث العناصر والمكونات التي تتكون منها الجملة العربية ليخصه بالإسناد الأصلي الذي هو رابطة ولابد فيه من طرفين مسند ومسند إليه، فيحترز بذلك عن بعض ما ركب من اسمين كالمضـاف والمضـاف إليه والتابع والمتبوع وبعد المركب من

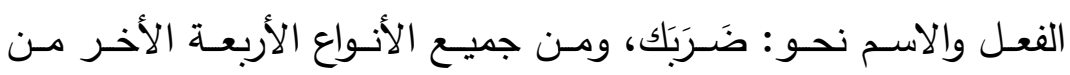
التركيبات الممكنة بين الكلم الثلاث وهي (اسم مع حرف، وفعل مـع فعل،

$$
\text { أو حرف، وحرف مع حرف). }
$$

فأحد أجزاء الكلام هو الحكم أي الإسناد الذي هو رابطة كما ذكر • ولابد

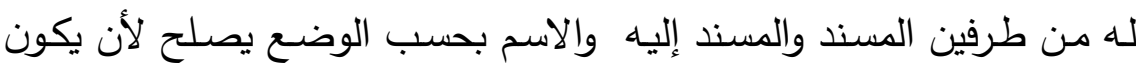

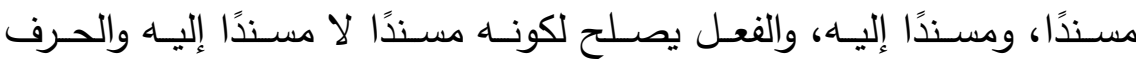

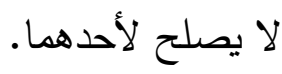
أما الاسم فلأنه يدل على الثبوت لثبوته يصلح للإخبار عنه والإخبار بـ لذلك أتى مسند ومسند إليه. وأما الفعل فلأنه يدل على الحدث والحدث غير ثابت بل متغير فيصلح للإخبار باه وليس الإخبار عنه وأما الحرف فلا يصلح لهذا ولا ذالك لأن معناه مع غيره وليس معناه في نفسه. • 1- يحدد الرضي مكونات التراكيب الإسنادية فالاسمان يكونان كلامـا، لكون

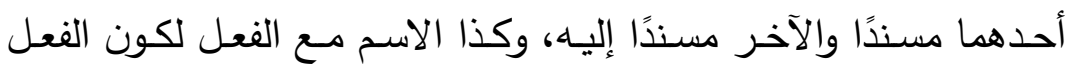
مسندًا والاسم مسندًا إليه والاسم مع الحرف لا يكونان كلاما، إذ لو جعلت الاسم مسندًا، فلا مسند إليه، ولو جعلته مسندًا إليه فلا مسند. 


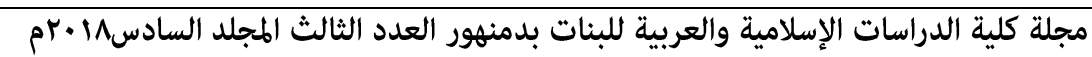

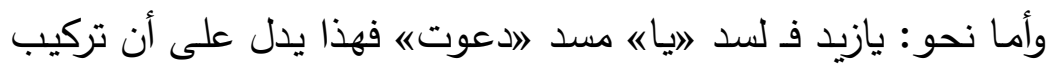
النداء تركيب إسنادي عند النحاة في التراث النحوي وهو المقرر من أمثلة ابن جني. والفعـل مـع الفعـل أو الحرف لا يكونـان كلامـا لعدم المسـند إليـه، وأمـا الحرف مع الحرف فلا مسند فيهما ولا مسند إليه. 11 فعلي أو اسمي، كما أنه يرى أنها أعم لأنها تقع على ما يفيد وما لا يفيد. أما الكلام فلا يوضع إلا فيما يغيد. ويوافقه في هذا السيوطي. r ا - اختفـاء مصسطلح الجملة قبـل عصسر المبـرد، ثم ظهوره بظهوره حيـث استعمله في كتابه المقتضب.

"ا : استخدام مصطلح 》الكلام) قبل عصر المبرد بأنه: 》اللفظ المفيد فائدة(1) يحسن السكوت عليها، ولابد فيه من التركيب وجودًا أو تقديرًا . يقول ابن مالك: - 20 - 20

ع ا - نصـل مـن خـلال المناقثـات إلى تحديد علاقـة الكـلام بالجملـة ووجـود فريقين، فريق يرادف الكالام بالجملة وفي المقدمـة لهؤلاء ابن جني الذي جاء تعريفه غاية في الاقة والفهح وانتصر لله بعض المحدثين (؟). وكذلك أمثلته، لأنه بهذا التعريف يتيح الفرصـة لدراسـة أنماط التراكيب المختلفة، واعتبار كل تركيب مستقل بنفسه مفيد لمعناه 》جملةًا في صورتها التي قيلت بها. ويُعَدُ توسعه هذا -بإعطاء أنماط متعددة 》للجملة) - يعبر عن بصيرة ناقدة في صورة الجملة ارتباطًا بآدائها لحاجة الموقف اللغوي.

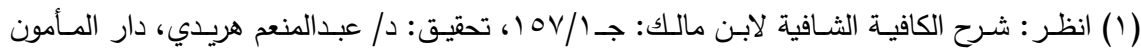

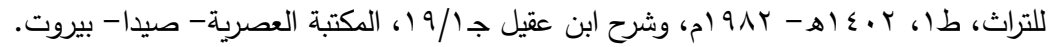

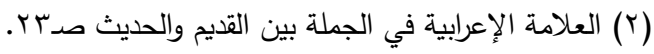




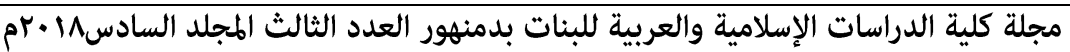
أمـا الزمخثري فقد انحصـر تعريفـه للجملة في صسورتين اثنتين بقوله: الكلام: هو المركب من كلمتين أسندت إحداهما إلى الأخرى: فلم يظفر تعريفه بالتوسع والدقة التي ظفر بها تعريف ابن جني وربما لخص كل ما أتى بـ ابن جني في عبارته بدون توسع. والفريـق الآخر : يـرى الفصـل بينهمـا على نحـو مـا ذهـب إليـه الرضـي وتبعه ابن هشام والسيوطي.

والحقيقتش: أن مـا ذكره ابن هشـام هو مـا جرت عليه كتب النحو المتأخرة فيعرفون الكحلام في صدر كتبهم، وينعتونه بالإفادة، وحين يتحدثون عن الجمل التي لها محل من الإعراب والجمل التي لا محل لها من الإعراب يقولون: جملة الصلة وجملة الشرط وجملة الجواب وهكذا('). 1 - أن الجملة عند النحاة لم تكن نقطة البدء في دراستهم، فلم يحددوا الصورة الثـلية للجملـة العربيـة تحديدًا دقيقًا، بحيـث يصـبح لهـا ضـابط فتكون

$$
\text { دراستهم بعد ذلك تحليلً نحويا لها. }
$$

ولكن تتـاولهم للأبـواب المختلفـة التي تمثل الوظـائف النحويـة المتعددة يـوحي بتصـور ذهني معين تدور في إطـاره الجملـة العربيـة، وهذا التصـور الذهني يقوم على أسس خاصة تنبني على تقسيمهم للكلمة وفهمه للعلاقة بين أجزاء الجملة، وتأثير بعضها في البعض الآخر، والترتيب بين هذه الأجزاء(؟).

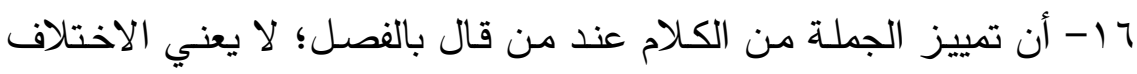
بينهما دائما، فقد يلتقيان، فتكون الجملة كلامًا، والكلام جملة وقد ظهر ذلك من خلال بعض الأمثلة التي ضربها ابن جني، وفي حديثه عنها، ووصفها بأن كلا منها هو جملة وكلام، نحو: زيد أخولك، قام محم، في 


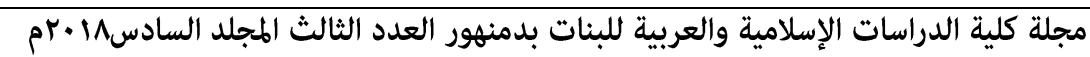

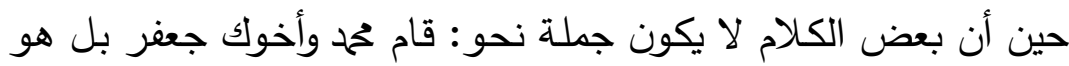

$$
\text { جملتان وقد يكون أكثر (1). }
$$

V أن الجملة تعد وحدة الدرس النحوي في الدراسات اللغويـة الحديثة لذا فقد تعددت محاور البحث فيها عند الباحثين العرب، بتفسير علاقتها بالكلام من جهة، وتفسير علاقتها باللغـة من جهة أخرى، فعلاقتها وطيدة إذن بكل منهمـا، فـالكلام لا يُدْرَس منفصـلً عن اللغـة إلا عند اعتباره عمـلا صـوتيا بحتا مقطوع الصـلة بالمعنى؛ فـإن الدراسـة اللغويـة للكـلام تجعلـه حتى على هذا المستوى الصوتي على صلة باللغة(؟). ربما قصد النحاة بمقتضى تعريفهم بعدم تحديد ضـابط للجملة ما قصده بعض علماء اللغة المحدثين بعبارة "الحدث اللغوي". 1 ا - وعي العلماء قدامى ومحدثين بمصطلح -اللغة والكلام - وربطه بدلالته من حيث كونـه عملًَ حيا ونشاطا تنفيذيا للنظلام اللغوي، لوحظ ذلك من وهن التحليل الاشتقاقي الذي قدمـه ابن جنـي للكـلام حيث ربط الكـلام بالكلم والكالام والكلوم وهو الجراح، لمـا يدعو إليه ولمـا يجنيه في أكثر الأمر على المتكلمة، ومعلوم بداهة أن ذلك لا يكون من نظام مخزون في الذهن بل من قول مفيد صادق عن قائلهي(r") 
الإسناد والجملة العربيةبين القدامى والهحدثين دراسة تحليلية مقارنة )

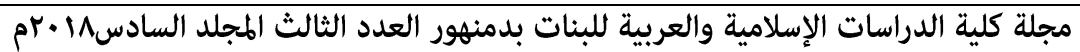

\section{الفصال الثالث}

\section{مفهوه الإسناد في النحو الحلديث وعالاقته بالجملتي}

وضتح نحاة العصر الحديث مفهوم الإسناد عند تعريفهم الجملة العربية،

إذ أن الإسـناد يـرتبط بالتراكيـب اللغويـة باعتبـار الأصـل في الجملـة ومكـون عناصرها حيث ذهب اللدكتور مهلي المخزومي- في تعريف الجملـ إلى قوله: \الجملة هي الصورة اللفظية الصغرى للكلام المفيد في أية لغة من اللغات، وهي المركب الذي يبين المتكلم بـه أن صسورة ذهنية كانت قد تألفت أجزاؤها في ذهنه، ثم هي الوسيلة التي تنقل ما جال في ذهن المتكلم إلى ذهن

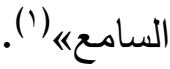

فقد أفاد هذا التعريف عدة أمـور أولها: ترادف الكلام مع الجملة

في حال كونها مفيدة. فهو بذلك يشترط الإفادة. ثانيها: اشتراط التركيب المعبر عن الصورة الذهنية. وقد أضـاف لمـا سبق: أن الجملة التامـة التي تعبر عن أبسط الصسور الذهنية التامـة التي يصـح السكوت عليها، تتألف مـن ثلاث عناصـر رئيسية

ا- المسند إليه، أو المتحدث عنه، أو المبنى عليه. r- المسند الذي يبنى على المسند إليه، ويتحدث به عنه.

$$
\text { r- الإسناد أو الارتباط المسند بالمسند إليه(؟). }
$$

وبهذه الإضـافة للإسـناد يكون قد اتفق مـع النحاة في تعريفاتهم إلا أنسه أنكر التقدير في الإسناد فقال: اوليس في العربية غالبا من لفظ يدل على الإسناد، كما في غيرها من اللغاته(ץ).... ولكن الجملة العربية ـفيما يبدو -

$$
\begin{aligned}
& \text { ( (1) في النحو العربي نقد وتوجيه للدكتور / مهدي المخزومسي- دار الرائد العربي- بيروت- لبنان طب }
\end{aligned}
$$

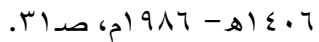

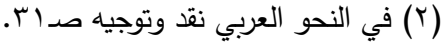

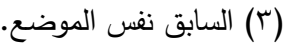




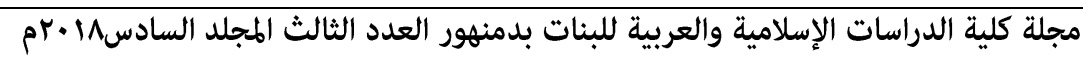
كانت تتضمن في استعمالاتها القديمة شيئا من هذا، معبرًا عنهـ بفعل الكينونـة، ولكنه انقرض في الاستعمال الشائع، وبقي له آثار احتفظت بها بعض الثواهد التي يستشهد بها النحاة على زيادة كان كقول الثاعرة:

\section{أنت تكون ماجد نبيل ... إذا تهب شمال بليل (1)}

فالكلمة (تكون) عند النحاة زائدة هنا، لأنها لم تجر جريان (كان) في الاستعمال من رفع الاسم ونصب الخبر، وهي فيما أزعم فعل الكينونـة الذي يدل على الإسناد.... (r).

فقد أشار بوضوح إلى الاستغناء عن (الإسناد) في العصر الحديث لأن الجملة العربية في أكثر حالاتها تتضمن شينًا آخر يشير إلى الإسناد دائمًا شيئًا ألحق بالمسند إليه، وألصق بـه، وهو صوت الضدة في النسيم، وفي خحم في قولك: (هب النسيءُ)، و (عحم الشاعر).

وقد ألحق به ليكون علما على كونه مسندًا إليه، وقد ثبت بالاستقراء أن

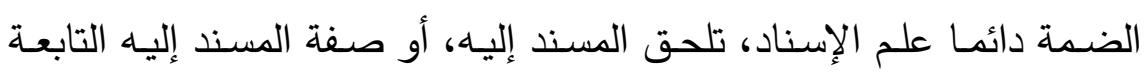

ومسن ثم فهو لا يعترف بالحذف أو التأويـل في نحـو: إيـاك والشـر أو

أسلوب النداء في نحو يازيد ونحو وقولك: والله لأفعلن.

توافق بعض الباحثين من نحساة العصـر الحديث وهو الدكتور مهدي

المخزومسي مـع نــاة التراث في الإسـناد إذ أن الجملـة عند تتألف مـن ثلاث عناصـر هـي المسند إليه، أو المتحدث عنـه، أو المبنـي عليه، والمسند الذي يبنى على المسند إليه، ويتحدث بـه عنه، والإسناد وهو ارتباط المسند بالمسند

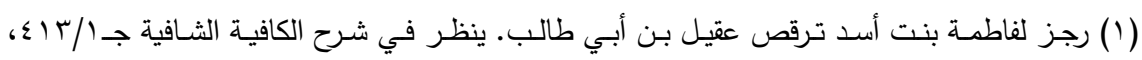

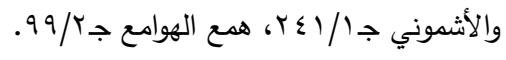

(Y) في النحو العربي نقد وتوجيه صد آب، فما بعدها.

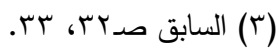




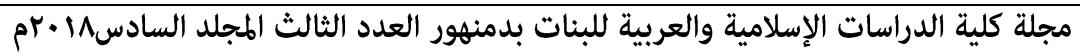
وبهذه الإضـافة يكون المخزومي قد اتفق مـع نحاة التراث في تصنيف الجملة العربية إلى جمل إسنادية إلا أنه اختلف مـع نحاة التراث في أنه أنكر (التقدير) في الإسـناد فقال: اوليس في العربيـة غالبـا مـن لفظ يـدل على الإسناد، كما في غيرها من اللغاته فهو لا يعترف بالحذف أو التأويل في نحو أسلوب النداء (يازيد) وأسلوب التحذير نحو (إياك والثر) وأسلوب القسم نحو: و الله لأفعلن، ونحوها.

إذ أنه يسند مثل هذه التراكيب إلى أن الجملة العربية كانت تتضمن في استعمالاتها القديمة شيئا من هذا معبرًا عنه بفعل الكينونـة، ولكنهـ انقرض في الاستعمال الثائع وبقي لله أثار احتفظت بها بعض الشواهد التي يستشهد بها النحاة على زيادة (كان) كما في قول الثاعر:

\section{أنت تككون ماجد نبيل ... إذا تهب شهال بليل}

فلفظـة 》تكونش زائدة لأنها لـم تكن واردة على استعمال كان الناقصـة إذ كان الناقصة يرفع الاسم بعدها وينصب الخبر • وحمل ذلك عنده على فعل الكينونة الذي يدل على الإسناد. لذا يمكن الاستغناء عند المخزومي عن الإسناد، لأن الجملة في أكثر آلر

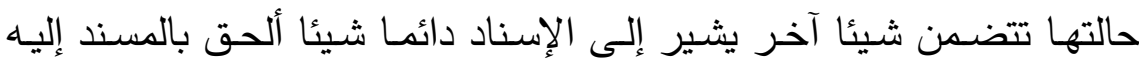
وألصق به، وهو صوت الضمة في النسيم في قولك: هب النسيمُ، وقد ألحق به ليكون علما على كونـه مسند إليه، وقد ثبت بالاستقراء أن الضـمة دائمسا علم الإسناد تلحق المسند إليه، أو صفة المسند إليه التابعة له.

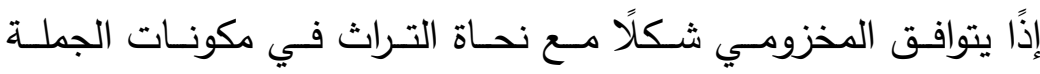
الإسنادية من ثلاث عناصـر : مسند ومسند إليه ورابطة الإسناد إلا أنـه أنكر التقدير والحذف والتأويل.

وقد كـان مـن أصسحاب هـدا الـرأي: عبـد اللطيف حماسـنه، فلم ينكر الإسناد ولكن لا يشترطه في كل جملة مفيدة وبالتالي فلا إسناد في نحو:

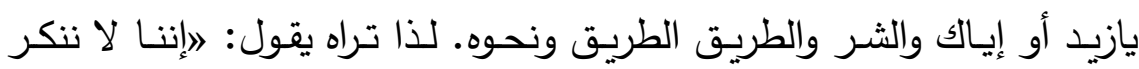




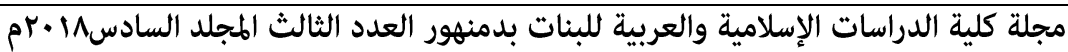
الإسناد، فهو قرينة معنويـة من قرائن الجملة، ولكن هذا لا يعني إن كل جملة مفيدة- لابد- مشتملة على الإسناد. إذ إننا ينبغي أن نعترف بوجود جملة غير إسـنادية، كمـا ينبغـي أن نعترف بنـاء على الواقع اللغوي، بوجـود جملـة ذات طرف واحد مؤدية لمعناها اعتمادًا على قرائن الأحوال، أو الموقف اللغوي الذي يكون فيه الكلام أو السياق وهو كبرى القرائن. لماذا يقدر النحاة جملة من فعل وفاعل محذوفة في مثل قولك: (والله لأَفَعَنَ) ويْعلون القسم دالًا على هذه الجملة المحذوفة؟ وكذلك أسلوب النداء، فإذا قلت (ياححم) فهذه جملة فعلية في نظر النحاة، ويرحم الله أبا علي الفارسي الذي عد هذا وحده كلاما مكتفيا بنفسه، أما النحاة فإنهم يرون أن (يا) سدت مسد فعل هو أدعو أو أنادي، وهذا الفعل لا يظهر • (ألا ترى أنه لو تُجشّمّ إظهاره فقيـل أدعو وأنـادي زيـدًا لاستحال أمـر النداء فصـار إلى لفظ الخبر المحتمـل للصـدق والكذب، والنـداء ممـا لا يصـح فيـه تصـديق ولا تكذيب)(') وحتى مـع إحالـة المعنى وإزالـة الغرض لا يـرى النحساة بأسـا مـن حسبان هذا

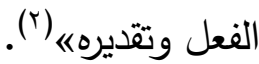

فقد حاول الدكتور مهدي المخزومي أن يقدم في تعريف الجملة مفهومًا جديدًا، فعلى حين يعرف ابن جني الجملة بأنها كل لفظ مستقل بنفسـه مفيد

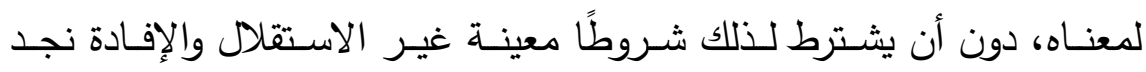
الـدكتور مهـدي المخزومسي يتفـق مـع هـذا الفهم حـين يعـرف الجملـة بأنهـا: الصورة اللفظية الصغرى للكلام المفيد في أية لغة من اللغات، وهي المركب الذي يبين المتكلم به أن صورة ذهنية كانت قد تألقت أجزاؤها في ذهنه، ثم هي الوسيلة التي تنقل ما جال في ذهن المتكلم إلى ذهن السامع. 


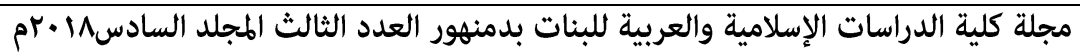
والجملة التامـة التي تعبر عن أبسط الصـور الذهنية التامـة التي يصـح السكوت عليها(')، وبناء على هذا الفهم ناقش ابن هثام في بعض الجمل التي عرض لها كأسـلوب النداء، لأن النداء أسلوب خاص يؤدي وظليفته بمركب لفظي خاص، وله دلالة خاصة يحس بها السامع والمتكلمه(؟). ومـع استقلال هذا الأسلوب بأداء معنى معين لا يعده الدكتور مهدي المخزومسي جملة كمـا يعده النحاة، ولا جملـة غير إسـادية كمـا يـراه الدكتور عبدالرحمن أيوب(r)، وكما يراه الدكتور حمد عبداللطيف حماسة. الأن الجملـة إنمـا تقوم على أسـاس من إسـاد يؤدي إلى إحداث فكرة تامة ولا يقوم مثل قولهم (يا عبدالله) على مثل ذلك الأساس، ولا يؤدي مثل تلك

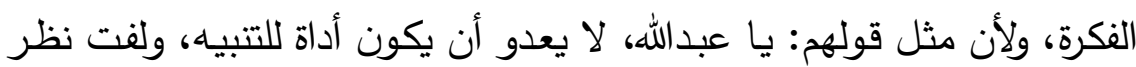
(المنادى، ولا يختلف عن أمثاله، من الأدوات التي تؤدي ما يؤديه مثل هذا التعبير من وظليفة، مثل (ألا) التي للتبييه و (هـا) التي للتنبيه أيضًا وغيرهمـا إلا في أنه مركب لفظي لا يرتفع إلى منزلة الجملة، ولا يصـح تسميته بالجملة

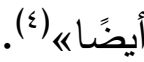

فبعد أن عرف الجملـة بتعريفاتـه السـابقة وهـي تعريفـات صـحيحة مـن وجهة نظر حماسة يعود مرة أخرى فيشترط الإسناد مقوما من مقومات الجملة، فالتركيب الذي لا إسناد فيه (أسلوب خاص) كالنداء يسميه 》المركب اللفظيه فهو يقول عن النداء مرة أخرى اوخلاصـة القول أن النداء ليس جملة فعلية ولا جملة غير إسنادية، وإنما هو مركب لفظي بمنزلة أسماء الأصسوات يستخدم لإبلاغ المنادى حاجة أو لدعوته إلى إغاثة أو نصرة أو نحو ذلكه(•).

$$
\begin{aligned}
& \text { (1) في النحو العربي نقد وتوجيه صداس. }
\end{aligned}
$$

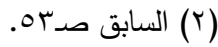

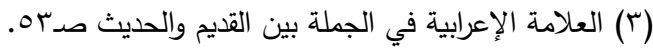

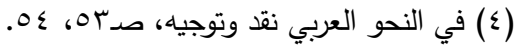

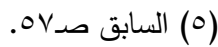




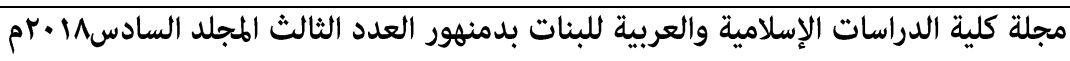

واعترض على قول المخزومي في النداء بالمركب اللفظي: قال:

اولست أدري هل يسمى كل تركيب غير إسنادي مفيد (مركبا لفظيًا) أو أن هذا (مصـطلح خـاص) لمـا عدا الإسـناد؟ وهـل أسـاء الأصـوات عنده مركب لفظي كما يفهم من تشبيهه أسلوب النداء بها؟ لقد وصف أسلوب القسم

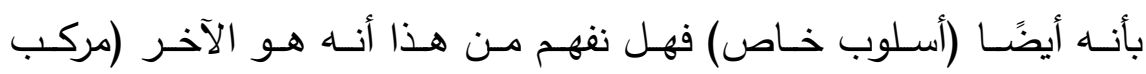

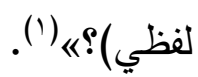

ولذلك ينتقد على المخزوهي بأنه اشترط الإسناد أساسًا تقوم بـه الجملة، وعندما خذله الإسـاد في إحداث فكرة تامـة في أسلوب الشرط، لأنـه يتكون مـن جملتين تربطهمـا أداة شرط، كل منهمـا جملة تحقق فيها شـروط الإسـناد، ومـع ذلك لـم يكتمل معنـى كامل، ولا فائدة يحسـن السكوت عليهـا؛ تراجـع بعض التراجع فقال: اليست جملة الشرط جملتين إلا بالنظر العقلي، والتحليـل المنطقي، أمـا بـالنظر اللغـوي فجملتـا الثـرط جملـة واحدة، وتعبيـر لا يقبـل الانشـطار، لأن الجـزعين المعقولين فيهـا إنمـا يعبـران معًا عـن فكرة واحدة، لأنك إذا اقتصرت على واحدة منهما أخللت بالإفصاح عما يجول في الإس ذهنك، وقصرت عن نقل ما يجول فيه إلى ذهن السامع)(ז)، وسمى كل واحدة من جملتي الشرط والجواب (عبارة)(r)، أي عبارة الشرط وعبارة الجواب. لذا ماذا يقول المخزومي عن (قائم أبوه) في جملة مثل: (حمد قائم أبوه) فقد تحقق الإسناد بين (قائم) و(أبوه) وهي مع ذلك ليست في هذا السياق جملة مستقلة (๕).

أما حماست فيعرف الجملت بأنها: لاكلام نقرؤه أو نسمعه مكون من

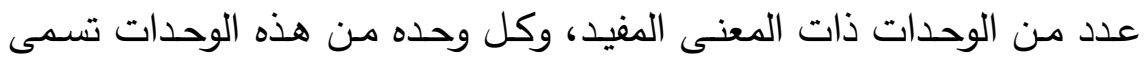

$$
\begin{aligned}
& \text { (1) العلامة الإعرابية في الجملة في القديم والحديث صدءه. }
\end{aligned}
$$

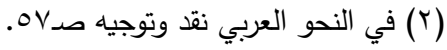

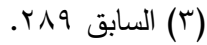

$$
\begin{aligned}
& \text { (乏) ينظر : العلامة الإعرابية صد. البائ }
\end{aligned}
$$


الإسناد والجملة العربيةبين القدامى والمددثين دراسة تحليلية مقارنة )

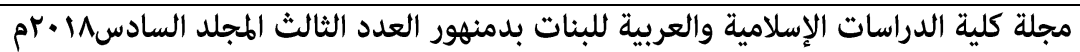

فالجملة هي وحدة الكلام فهذا الحديث مثلًً: "إنما الأعمال بالنيات وإنما لكل امـرى مـا نـوى"(') كـلام مكـون مـن جملتين الأولى هـي: إنمـا الأعمـال بالنيات، والجملة الثانية هي: وإنما لكل امرئ ما نوى، وكل واحدة منها تؤدي معنى مفيدًا، ولهذا تعرف بالجملة بأنها: قول مركب مفيد أي دال على معنى يحسن السكوت عليه.

والجملة تتألف من عدد من الوحدات المفردة، التي تجمعها علامة معينة

$$
\text { لتؤدي معا معنى مفيدًا (r). }
$$

فيكون هذا الباحث قد أفاد الإضـافت لهـا قد توقف عنـه النحساة

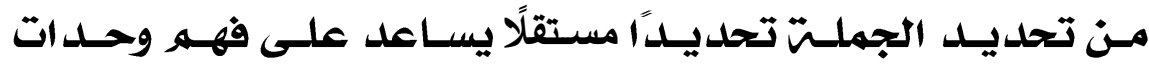

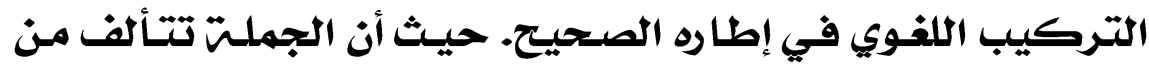
عدد من الوحد ات المعردة، التي تجمعها علامهن معينـن لتؤدي معا معنى مهيل - مهن.

ومن الباحثين أيضًا من يرى: أن الكلام يرادف الجملة جريا على ما

شاع عند النحاة العرب الذين لم يفرقوا بينهما.

مـن هـؤلاء: الأستاذ حسن عباس: يقول في كتابـه (النحو الوافي): ״الكلام أو الجملة هو: ما تركب من كلمتين أو أكثر، ولله معنى مفيد مستقل مثل: أقبل ضيف، وفاز طالب نبيل ... فلابد في الكلام من أمرين معا، وهما "التركيب" و"الإفادة المستقلة" فلو قلنا: أقبل، أو فاز فقط، لـ يكن هذا كلامـا، لأنه غير مركب ولو قلنـا: أقبل صباحا ... أو فاز يوم الخميس ... أو لن

(1) رواه البخاري بلفظه في صحيحه، كتاب الإيمان جـ / • r، رقم 0؛ وكتاب الإيمان والنذور باب النية

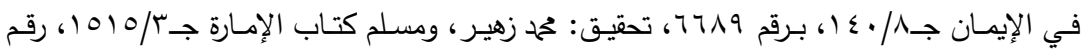

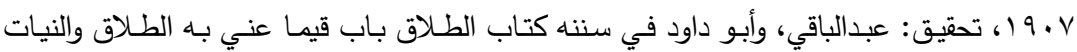

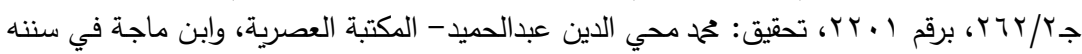

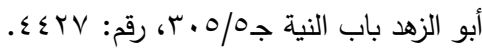

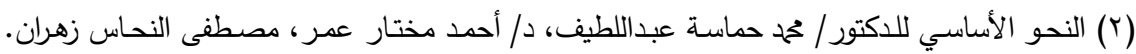

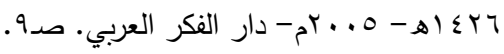




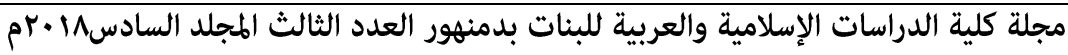

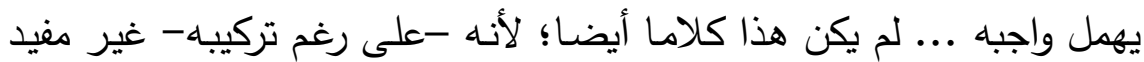
فائدة يكتفى بها المتكلم أو السامعب( (1).

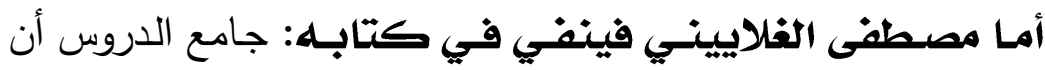
تكون الجملة مرادفة للكحلام حيث قال: الالجملة: قول مؤلف من مسند ومسند

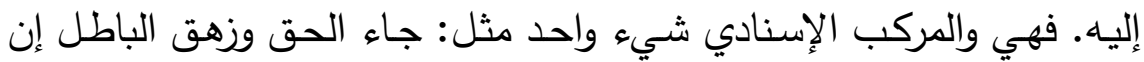

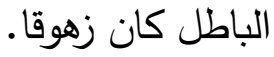
ولا يشترط فيما نسميه جملـة، أو مركبا إسـاديا، أن يفيد معنى بنفسـه، كما يشترط ذلك فيما نسميه كلاماه(ب).

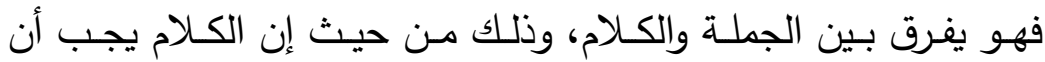
تتحقق فيه الفائدة، أي أن يحصل فيه الفائدة التامـة، وهذا على عكس الجملة التي ليس من الواجب أن تتحقق فيها الفائدة التامة.

أمـا عبـده الراجحي فيعرف الجملة في مصنفه (التطبيق النحوي) بأنهـا هـي: \الكـلام التـي يتركب مسن كلمتـين أو أكثـر ، ولـهـ معنـى مفيـد

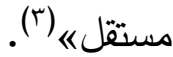

والراجحي هنا يعرف الجملة بناء على تعريف النحاة إياها. في حين يعرف فخر الدين قبـاوة الجملـن على أنها عنصر من فن عناصـر الكـلام فيقول في كتابه: (إعراب الجمل وأشباه الجمل): 》الكلام هو القول الـدال على معنى يحسـن السـكوت عليـه وتتـألف مـن عناصـر ثلاثـة:

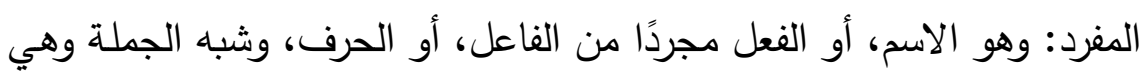
الظرف أو الجـار الأصـلي والمجرور، والجملـة وهي الفعل والفاعل أو المبتدأ

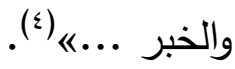




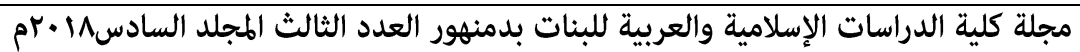
النتيججن:

ا- وقوف أحد الباحثين العرب وهـو الدكتور محمد عبداللطيف حماسـة على

تحديد مفهوم للجملة، يساعد على فهم وحدات التركيب اللغوي في إطاره الصحيح، حيث إن الجملة عنده تتألف من عدد من الوحدات المفردة التي تجمعها علامة معينة لتؤدي معنى مفيد.

وهذا يظهر اختلافه عن نحاة التراث بهذه الإضـافة إذ أنه حلل الجملة تحليًا عضويا وهذا التحليل العضوي من سمات النحو الحديث. ب- توافق حماسـة مع نحاة التراث في اشتراط الإفادة في الجملة حتى يحسن السكوت عليها.

ب- الجملـة عند حماسـة (قول مركب) كل تركيب فيـه إفـادة، وبضـميمة كل تركيب مفيد إلى الآخر - تحصل الإفادة فيحسن السكوت عليه فاشترط التركيب وهذه مخالفة لم يثترطها نحاة التراث. ع- مخالفـة حماسـة في النحو الحديث مـع نحساة التراث في اشـتراط الإسـناد لحصول الفائدة وإنما عنده القول المركب - أعم مما أشير إليه إذ أن في التركيـب مـا فيـه إسـاد وغير إسناد إلا أنـه في النهايـة قول مركب مفيد فمتى تحصل الإفادة تكون الجملة. إذن الجملة يدخلها أصناف كثيرة من التراكيب قد تكون التراكيب إسنادية وقد تكون التراكيب غير إسنادية إلا أنها مفيدة فتكون كلها من قبيل الجمل. وبهذا يثبت تعريفه مخالفته لنحاة التراث النحوي إذ تصنيف الجمل عنده لا تقف إذا على ما توافر فيها الإسناد بل أنه يحتمل جملً غير إسنادية طالما أنها تركيب أو مركبة ومفيدة. بهذا يضيف هذا التعريف تصنيف جديد للجملة العربية في السياق اللغوي إذ أنه يصنف إلى جمل إسنادية وجمل غير إسنادية. وهو مما يخالف ما عليه التراث النحوي. ه- يتوافق المخزومي مع نحاة التراث في ترادف الكلام والجملة. ج- اشتراط التركيب المعبر عن الصورة الذهنية وبذلك يختلف مع نحاة التراث. 


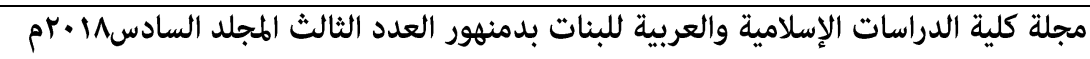

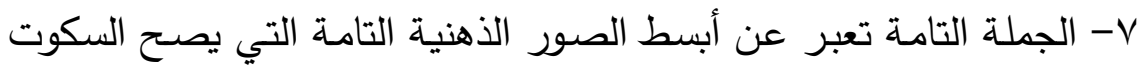
عليها متفق عليه عنده مع نحاة التراث. ^- اتفاق حماسـة والمخزومي في رفض التقدير والتأويل واعتبار مثل (يازيد) و (والله لأفعلن) وحده كلامـا مكتفيا بنفسـه ومثل هذه العبارات تعد جمل غير إسنادية عند حماسة وتعد تركيب لفظي عند المخزومي. 9- توافق المحسن عباس مع نحاة التراث في مرادفة الكلام للجملة. • 1- رفض مصطفى الغلاييني مرادفة الكلام للجملة. 1ا- الجملة عند مصطفى الغلاييني قول مؤلف من مسند ومسند إليـه فهي

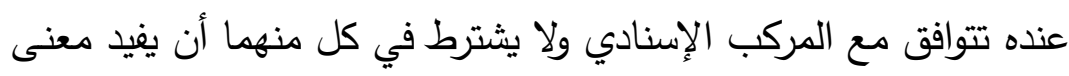

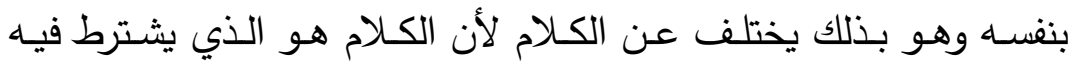
الإففادة.

$$
\begin{aligned}
& \text { وبذلك يختلف الغلايني مع القدامى في: } \\
& \text { أ- القول بمرادفة الكلام للجملة. } \\
& \text { ب- القول بالإفادة في الجملة. }
\end{aligned}
$$

ج- ما ذكر فيه الإسناد بلقب الجملة أو بالمركب الإسنادي. r ا - يستتتج من تعريفات الباحثين الدارسين للجملة بأنهم في نقطة التقاء مع

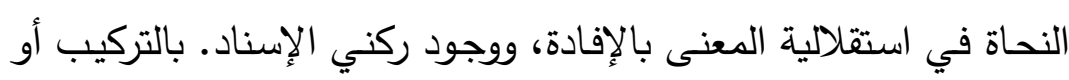
التأليف.

إلا أنهم لا يشترطون الإسـاد مثلمـا لجأ إليه المتأخرون أمثال الرضـي وابـن هثـام ومـن تـبعهم لأن هـؤلاء البـاحثين يعترفـون بوجـود الجملـة غيـر الإسنادية ولا ينبغي التأويل والتقدير معها. كما أنه ليس بالضرورة أن تحتوي الجملة العناصر كلها فقد تخلو الجملة من المسند إليه لفظا أو من المسند لوضوحه وسهولة تقديره. 


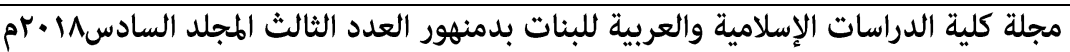
ثم يعترفون بوجود الجملـة ذات الطرف الواحد المؤديـة لمعناهـا اعتمـادًا على قرائن الأحوال والسياق والموقف اللغوي الذي يكون فيه الكحلام وهو كبرى القرائن.

ومـن ثم يعترضـون على تقدير النحاة في الجملـة ذات الطـرف الواحد

$$
\text { مثل: يازبد ونحوه. }
$$

مستدلين في ذلك بآراء بعض النحاة أمثال أبي على الفارسي وتلميذه ابن جني في أن مثل هذه الجملة ذات الطرف الواحد كافية في إفادة المعنى فلا جدوى من تقدير وتأويل. با - أن الجملة لم تحظ بتعريف شـامل دقيق عند هؤلاء الباحثين الدارسين؛ وذلك لصعوبة ضسط أحوالها ضسطا دقيقا، ولكونها تتمتع بأبعاد عديدة: صوتية، ونغسية، وذهنية، وتركيبية، ودلالية(').

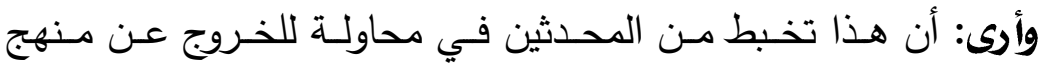
القدامى وهذا إنما يدل على أن الجملة العربية عصية في تعريفها أمام اختلاف الأساليب والتراكيب الواردة فيها. فما عابوه على القدامى وقعوا فيه، وهو عدم تحديد ضابط للجملة. ع ا - أخذ الباحثون على نحساة العربيـة أنهـم اقتفوا آثار المناطقـة في أجزاء القضية المنطقية، إذ رأوا أنها تتألف عندهم من موضوع ومحمول وعلاقة

$$
\text { بينهما (r) }
$$

》فقالوا بدورهم بأن الجملـة تتكون من كلمـات كمـا تتكون القضـية من دلالات على الأحداث أو الذوات أما أجزاء الجملة فهي المسند إليه، والمسند والرابطة، وهي نفس القضية المنطقية مع اختلاف في التسميةه(r).

( (1) انظر : بناء الجملة بين العربية والصينية، دارسة تطبيقية وتقابلية على سورة يوسف (بحث ماجستير )

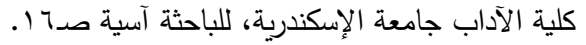

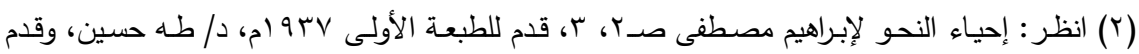

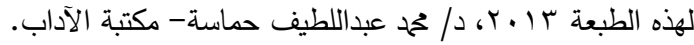

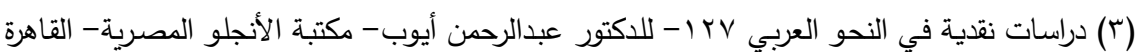




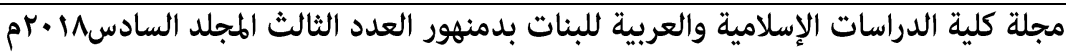

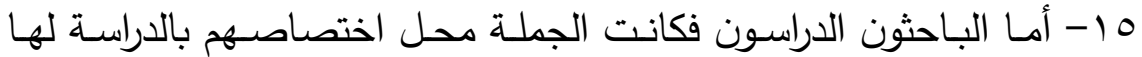

$$
\text { والبحث فيها. }
$$

والسبب في ذلك يرجع إلى أن الجملة هي الوحدة التي يتمثل فيها أهم خصـائص اللغة. لذا كان يجب أن تلتمس معالمها من استعمالات المتكلمين بها. ومما تواضعوا على استقلاله بالمعنى في الكلام لا في المنطق، وذلك لأن العادات اللغوية في كل بيئة هي التي تحدد الجمل في لغة البيئة('). والنحو لا يتجرد بهذا الفهم من خاصسية البحث في الإعراب ونظامـه

وأحواله بل يزداد اتساعًا بفهم مهمته على هذا الوجه الثامل(r). وأما الرد على قولهم بعدهر عنايت النحاة بالجملتش، ولم تكن من اهتمامهم فلم يعرضوا لها إلا حين يريدون أن يبحثوا موضوعًا آخرًا، ولم يشيروا إليها إلا حين يضطرون ... فقد رأينا ظهور مصطلح الجملة مع المبرد حيث قال في كتابه المقتضب وهو أقدم كتاب وصل إلينا في النحو والصرف بعد كتاب سيبويـا: اوإنما كان الفاعل رفعًا لأنها هو والفعل جملة يحسن السكوت عليها، وتجب بها الفائدة للمخاطب (r)" ويمكن لنا إذا أردنا تعريف للجملة عند النحاة العرب فما ورد في نص وس المبرد يكفي أن نقول الجملة هي مـع توافر فيها الإسناد والإفادة بحيث يحسن السكوت عليها، كما أنها أقل عنصر يتوافر فيه ذلك. هذا وقد شاع مصطلح الجملة وظهرت مؤلفات تحمل المسمى وتبحث فيه منها: كتاب الجمل في النحو للزجاجي (وسبه) وكتاب الجمل في النحو للأديـب الفاضـل حسـين بـن أحمـد المعـروف بـابن خالويـــ النحـوي الهمـداني المتوفي سنة ( • VIه)، والجمل في النحو للشيخ عبدالقاهر الجرجاني المتوفي

(1) انظر: من أسرار اللغة صـ • بr للدكتور إبراهيم أنيس- مكتبة الأنجلو المصرية، وانظر في العلامة

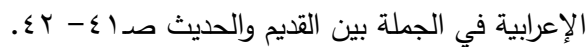

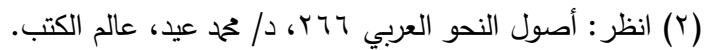

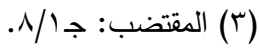




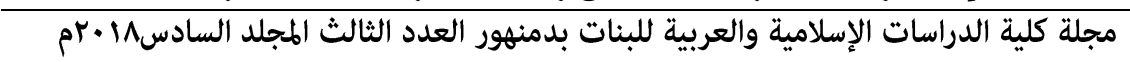

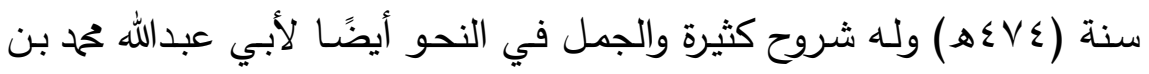
أحمد بن هشام النحوي المتوفي سنة ( • . هـ ) ورسالة في جمل الإعراب لبدر

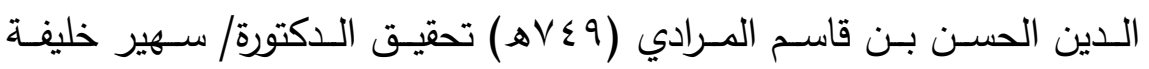
بالإضافة إلى تفرع مباحث في كتب النحاة تبحث في الجمل منها: تقسيم الجمل عند ابن هشام لجمل لها محل من الإعراب وجمل ليس لها محـل مـن الإعـراب في كتابـه (مغنـي اللبيـب) ويشـهـ بـه الـدكتور مهـدي المخزومي نفسه حيث ناقش هذا التقسيم عند ابن هثام. cressoso 
الإسناد والجملة العربيةبين القدامى والهحدثين دراسة تحليلية مقارنة )

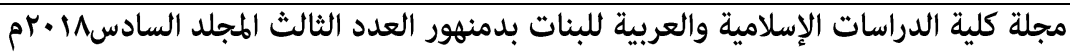

\section{النصل الرابع}

أثر الإسناد في الثحو الحلديث على التراكيب العربين

\section{(في الميزان)

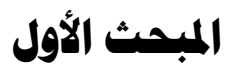

\section{أثره في الثقسيه الثناخي القديه}

فالجملت المفيدة في رأي النحاة: لابد فيها من وجود مسند ومسند

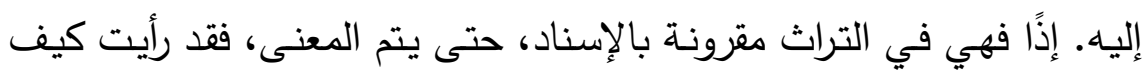
اشترط النحاة الإسناد لكي تحصل الإفادة. فالتركيب الإسنادي متى أفاد فائدة يحسن السكوت عليها كان جملة عند القدامى، ولذلك لقبت بالجملة الإسنادية. أمسا صسورها فلا تخرج عن اثثين: جملة اسمية وجملة فعلية، فالجملة الاسمية مكونـة من مبتدأ وخبر فهي المصدرة بالاسم، والجملة الفعلية مكونـة من فعل وفاعل فهي المصـدرة بالفعل. وقد وضـع هذا المعيـار سييويـه في كتابه، قال: اهذا باب المسند والمسند إليه وهما مما لا يغنى واحد منهما عن الآخر، ولا يجد المتكلم منـه بدًا، فمن ذلك الاسم المبتدأ والمبني عليه، وهو

$$
\text { قولك (عبدالله أخوك) و (هذا أخوك). }
$$

ومثل ذلك: (يذهب عبدالله، فلابد للفعل من الاسم، كما لم يكن للاسم

$$
\text { الأول بد من الآخر في الابتداء. }
$$

ومدـا يكون بمنزلـة الابتداء قولك: (كان عبدالله منطلقـا) و (ليـت زيدًا

منطلقّ) لأن هذا يحتاج إلى ما بعده كاحتياج المبتذأ إلى ما بعدهی('). واتبع النحاة منهج سيبويه في تصوير الجملة العربية، فيلزم تكوينها من

$$
\begin{aligned}
& \text { ثلاث عناصر هي: } \\
& \text { 1- المسند إليه (المبتدأ - الفاعل - نائب الفاعل). } \\
& \text { r- المسند (الخبر - الفعل). }
\end{aligned}
$$




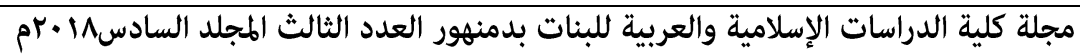

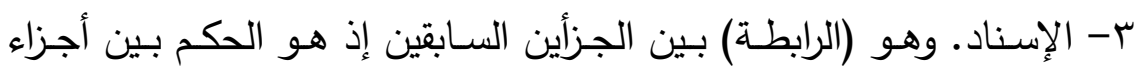
الكلام، وهو عنصر معنوي.

يقـول الرضـي فيـهـ: اوذلك لأن أحد أجزاء الكـلام هو الحكم، أي

الإسناد الذي هو رابطه، ولابد له من طرفين مسند ومسند إليهی(').

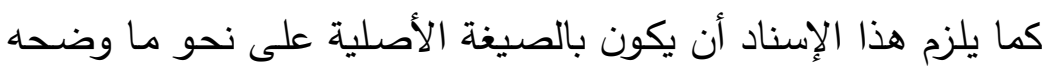
الرضـي (r) ليخرج إسـاد المصـدر واسـي الفاعل والمفعول، والصفة المشبهة والظرف فإنها مع ما أسندت إليه ليست بجملة (أو كلام). ويعد (أقائم الزيدان) جملة لكونه في معنى الفعل فهو بمنزلته، كما في أسماء الأفعال. ا- فعلى قول ابـن هشـام(): الاسـمية هـي التي صـدرها اسـ كـ (زيـد قـائم، وهيهات العقيق، وقائم الزيدان) عند من جوزه، وهو الاخفش والكوفيون. والفعلية هي: التي صدرها فعل، ك (قام زيد، وضُرب اللصُ، وكان زيد قائما، وظنتته قائما، ويقوم زيد، وقم). ץ- ومراده بصدر الجملة المسند أو المسند إليه، فلا عبرة عنده بما تقدم عليها

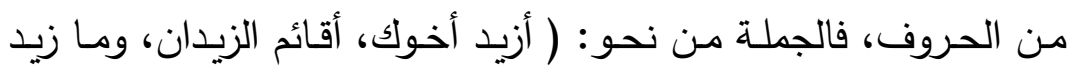
قائمسا، ولعل أبالك منطلق) اسمية ونحو: (أقام زيد، وقد قام زيدـ، وهـلا

$$
\text { قمت، وإن قام زيد) فعلية. }
$$

ب- والمعتبر عنده أيضًا ما هو صدر في الأصل فجملة: (كيف جاء زيد) فعلية لأن هذا الاسم في نية التأحير ، وكذا جملة (ياعبدالله) فعلية، لأن

مثل هذه الجملة صدرها في الأصل فعل والتقدير أدعو زيدًا. 


\section{من الملاحظ أن نصيب الاسه هو الأكبر في الجملت العربيت}

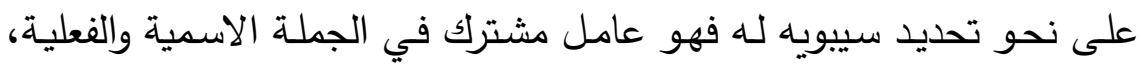

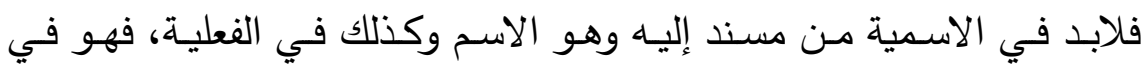

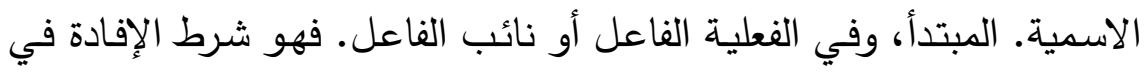

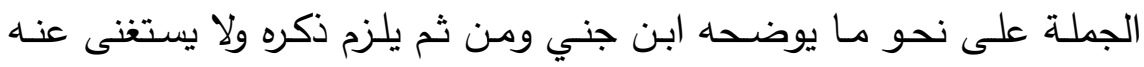

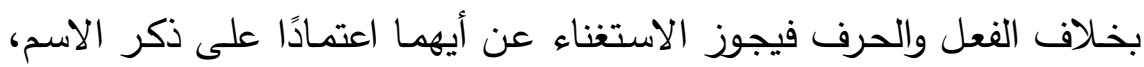

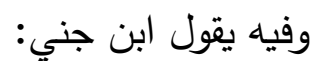
》لابد لكل كلام مفيد من: (الاسم) وقد تستغني الجملة المستقلة عن كل

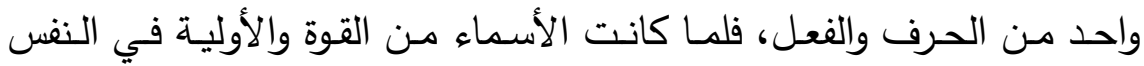

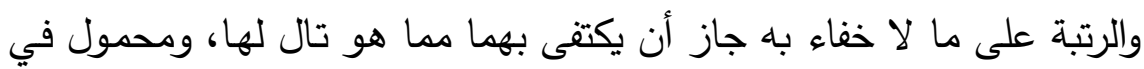
الحاجة إليه عليهاه (').

\section{صور البمثلة الفمالية في التزاث النهوي

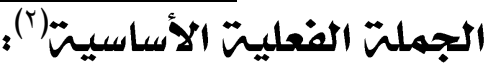

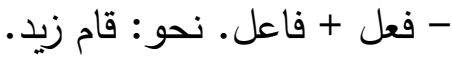

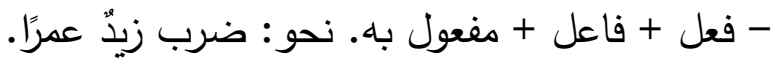

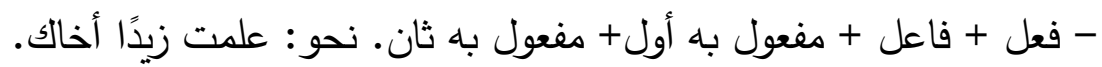

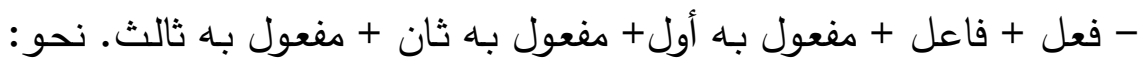

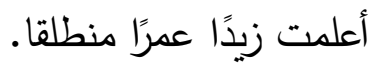
- فعل + فاعل + مفعول به + جار ومجرور أو ظرف. نحو: رأيت زيدا في

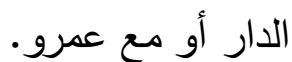
- فعل + فاعل+ جار ومجرور أو ظرف. نحو: جلس زيدُ في الدار أو مـع

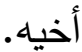

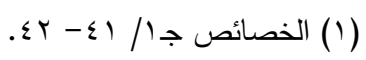

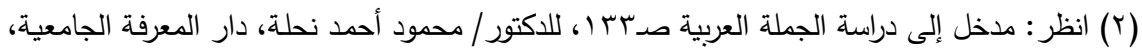

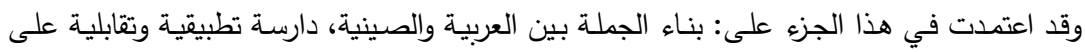
سورة يوسف. للباحثة آسية صد • -V -V - رسالة ماجستير - كلية الآداب- جامعة الإسكندرية. 


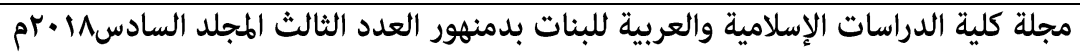
الأفعال في اللغن العربين تقسه التقسيه المشهور: ثلاثن أقساهية ماضٍ، ومضارع، وأمر •

على مـذهب البصـرين فيقصـدون بالمضـارع: الـذي يـدل على الحـال والاستقبال بأدوات خاصة علمًا بأن المعنى اللغوي لكلمة مضارع لا تقيد ذلك. فيهم يريدون بالمضـارع (أرى) الذي يضـارع الأسـماء. أي يشـابهها في التصريف والإعراب. أمـا الأمـر : فيقابلـهـ النهـي في اللغـة، وإن أرادوا بـه المقابـل والمضــارع،

$$
\text { وعند الكوفيين: قسمان (ماضٍٍ، ومضارع). }
$$

أما الأمر فهو مقتطع من المضارع بزيادة (لام الأمر).

ويرى الثراء:

رأيا مخالفـا فالفعل عنده ثلاثة أقسـام (ماضٍ ومستقبل ودائم)، ومـراده بالأول: الفعل الماضي، وبالثاني المضسارع، وبالثالث: اسم الفاعل، فجعل اسم الفاعل داخلا في فلك الأفعال (1). فالفعل في للغة العربية: كلمة تدل على حدث مقترن بزمن. وقل عرف سيبويه الفعل في كتابه فقال: اوأما الفعل فأمثلته أخذت من لفظ أحداث الأسماء، وبنيت لما مضـى،

ولما يكون ولم يقع، وما هو كائن لا ينقطعب(r).

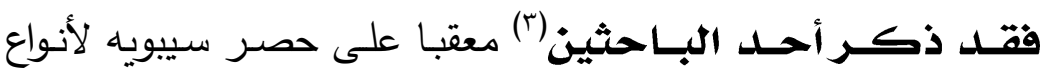
الزمان قائلًا: „لا نعلم أحدًا أتي في معنى هذا الكلام بما يوازيـه أو يدانيه، ولا يقع في الوهم أيضًا أن ذلك يستطاع. ألا ترى أنه إنما جاء في معنى قولهم: والفعل ينقسم بأقسام الزمان: ماضٍ وحاضر ومستقبل. 


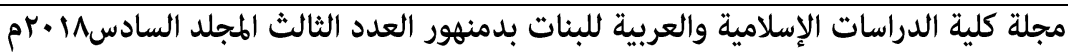
الزمن الأول: هو المقترن بالفعل الماضي الذي يدل على فعل وقع قبل زمن الإخبار به، كقولك: "ذهب الرجل" ولكن يخرج منه الفعل الذي هو على مثال الماضي أيضًّا، لكنه لا يدل على وقوع الحدث في الماضـي، نحو قولك في الدعاء: "غفر الله لك" فإنه يدخل في الزمن الثاني. اتزمن الثاني: هو الذي عبر عنه سيبويه بقوله بعد ذلك "وما يكون ولم يقع" وذلك حين تقول أمرًا: "اخرج" فهو مقترن بزمن مطلقٍ معلقٍ لا يدل على حاضرٍ ولا مستقبل؛ لأنه لم يقع بعد خروج، ولكنه كائن عند نفاذ الخروج من المأمور به. ومثله النهي حين تقول ناهيًا: "لا تخرج" فهو أيضًا في زمن مبهم مطلق معلق، وإن كان على مثال الفعل المضـارع فقد سلبت الدلالـة على الحاضـر والمستقبل لأنه لم يقع، لكنه كائن بامتناع الذي نُهي عن الخروج. ومثله أيضًا في الفعل المضارع في قولنا: "قاتلُ النفس يُعتل، والزاني المحصن يُرجم، ويغفر الله للتائب، فهذه أمثلة مضارعة، لكنها لا تدل على حاضر ولا مستقبل بل هي أخبار عن أحكام لم تقع وقت الإخبار بها، فهي أيضًا في زمن مبهم مطلق معلق، وهي كائنة حين حدوث القتل والزنا أو التوبـة. ويدخل في هذا الزمن أيضًا نحو قولنا في الدعاء: "غفر الله لك، أو رحم الله أمراً عرف قدر نفسـه" فعلى الرغم من أنه على مثال الماضي، فأننا لا نريد الإخبار عن غفرانٍ مضى الهى

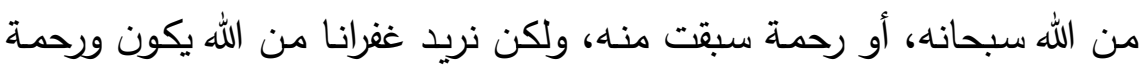
تحصـل فيمـا بعده فـالغفران والرحمـة لم يقعـا إذن، لكنتـا نرجو الدعاء أن يقـع ذلك.

الـزمن الثالـث: هو الذي عبر عنـه سيبويـه بقولـه: "ومـا هـو كـائن لا ينقطع"، فإنه خبرٌ عن حدثٍ كائنٍ حين تخبر به، كقولك: "عحم يضرب ولده" فإنها خبر عن ضـربٍ كائن حين أخبرت في الحـال ولم ينقطع الضـرب بعد مضـي الحـال إلى الاسـتقبال، ويلحق بهذا الـزمن الثالـث أيضًّـا مثل الفعـل

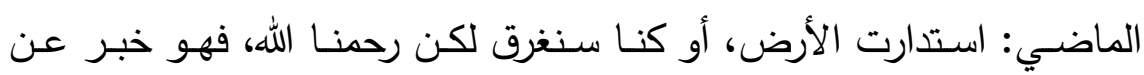




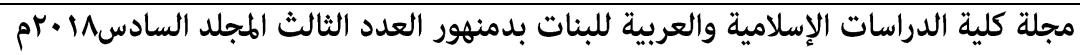

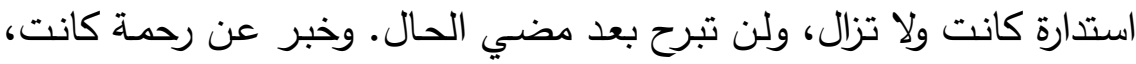

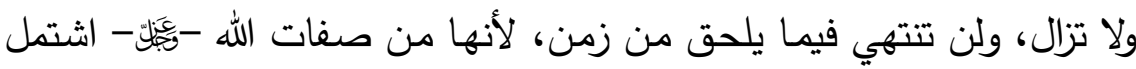
على الزمن الذي أهملته بقية تعريفات سائر النحاة، وهو الزمن المبهم المطلق المعلق الذي دلت عليه عبارة سيبويه بصياغتها الذكية والدقيقة أنواع وتقسيمات أخرى للفعل، وفق دلالـة المعنى من دون الزمن، كأفعال المقاربـة مثل "كاد وأوشك"، وأفعال الثروع مثل: "شرع وأنشأ، وطفق، وأخذ"، وأفعال الرجاء مثل:

"عسى، وحرى، واخلولق"، وهناك الأفعال الناقصة مثل: "كان وأخواتها"ه(").

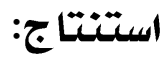

الفعل في الجملة الفعلية يلزم أن يكون مقترن بزمن وإن اختلف مسماه

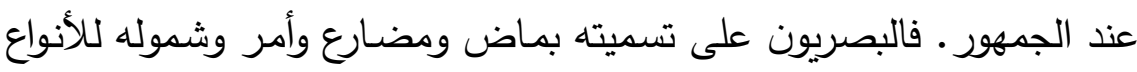
الثلاثة المذكورة، والكوفيون يقصـرونه على الماضـي والمضـارع ويـرون الأمر مقتطع من المضارع بزيادة لام الأمر • وسواء هذا أو ذالك فهو حدث مصحوب بزمن خالي من الذات. أما الفراء فثمل الفعل عنده نوعين: ما كان حدثا دل على زمن، أو ذاتا دلت على زمن أيضًا، لذلك تتوعت الأقسام عنده إلى ماض ومستقبل ودائم، فالأول الماضـي، والثاني المضـارع، أمـا الثالث فأراد بـه اسـم الفاعل. وبـلك تحدث المخالفة بينه وبين الجمهور وأرى أنه غير مخطئ في زعمـه، يثهد لـه مفاد عبارة سيبويه في تحديده لنوعية الفعل بقوله: (أما الفعل فأمثلته أخذت من لفظ أحداث الأسماء) فقوله: أحداث الأسماء يدخل فيها كل ما دل على حدث سواء مصحوب بزمن فقط أو مصحوب بزمن وذات في نفس الوقت نحو: اسم الفاعل حيث يدل على زمن وهو الدوام والثبـوت، وبذلك تكون إثـارة الفراء ليست بغرببة على أصناف الحدث أو على أصناف الزمن، وإنما الغريب فيها 
الإسناد والجملة العربيةبين القدامى والهددثين دراسة تحليلية مقارنة )

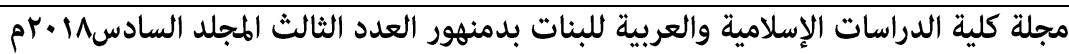

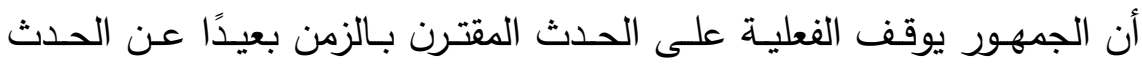
المقترن بالزمن والذات معًا. وخاصـة وأن اسم الفاعل يقوم بنفس مـا يقوم بـه الفعل على مذهب الجميع من إحداث تأثير ما؛ فإذا قلت: (زيد ضـاربٌ عمرًا)،

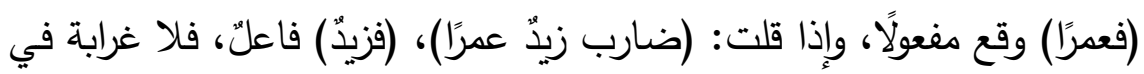
إعداد اسم الفاعل من قبيل الأفعال فهو فعل دل على الدوام على مذهب الفراء.

\section{صور الجمهلة الاسمية في التزاث النموي}

فالجملة الاسمية في التراث النحوي: مصطلح للإثـارة إلى أنواع متعددة من الجملة العربية. تجتمع معًا في أنه يتصدرها الاسم، مع وقوعه ركنًا إسناديًا فيها، ومقتضسى هذا التصدر الذي يشيع بين النحاة أنها لا عبرة في التصدر

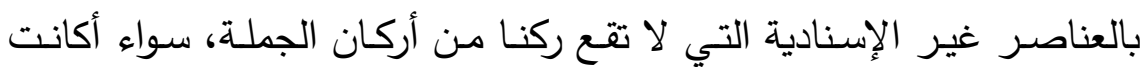

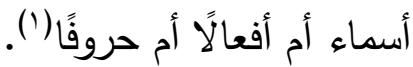

وتتكون الجملة الاسمية عند النحاة من مبتدأ وخبر، أو من مبتدأ ومرفوع

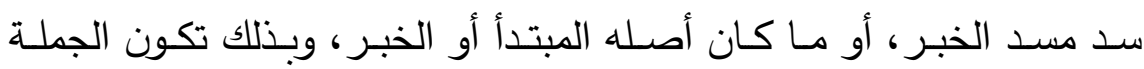
الاسمية عند النحاة إطارًا يضم في حقيقته أنماطًا متتوعة للصياغة والمكونات، مختلفة الروابط والعلاقات على النحو التالي: ا - جملتّ مكونت من مبتدأ وخبر.

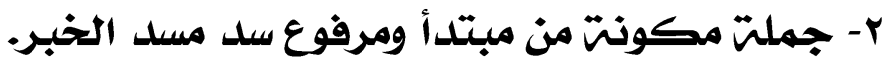

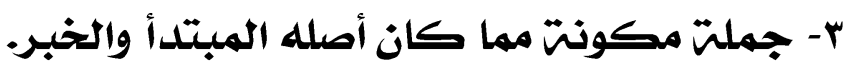

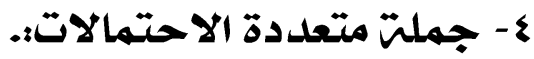
وزعهر ابن طلحتّ(r) أن الكلمة الواحدة قد تكون كلامًا إذا قامت مقام

$$
\text { الكلام ك (نعم) و(لا) في الجواب(r). }
$$

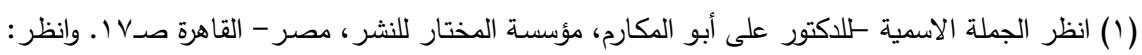

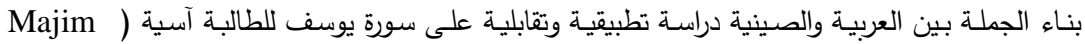
( ) صد (gjimg (r) هو محمد بن طلحة بن حمح بن عبدالملك الإثبيلي كان يميل إلى مذهب ابن الطراوة، توفي بإشبيلية سنة 
الإسناد والجملة العربيةبين القدامى والمددثين دراسة تحليلية مقارنة )

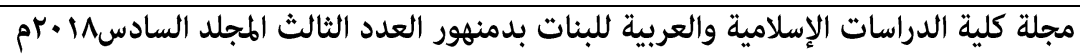
وهو مردود بأن: الكلام هو الجملة المقدرة بعدهما.

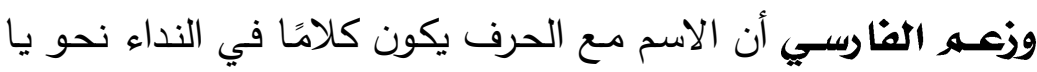
زيدُ، وأجيب بأن (يا) سدت مسد الفعل وهو (أدعو) و (أنادي).

وزعه بعضهه أن الفعل مـع الحرف يكون كلاما- مع مراعاة أن كل

كلام جملة في نحو: (ما قام) بناء على أن الضمير المستتر لا يعد كلمة('). وكل هذا مردود عليه على التقدير لأنه فقد الإسناد في الظاهر والإسناد مشروط في الجملة في التراث النحوي.

\section{البمهلة الكبرى والجمالة المغنرى}

أذاع هذا التقسيه ابن هشام في معانيه فيـرى: انقسـامر الجملـن إلى كبرى وصغرى.

فالكبرى هي: الاسمية التي خبرها جملة نحو: (زيد قام أبوه، وزيد أبوه

قائم)، والصغرى هي: (المبنية على المبتدأ)، كالجملة المخبر بها في المثالين. وقد تكـون الجملـة صـغرى وكبرى باعتبـارين، نحـو: (زيــ أبـوه غلامـه

منطلق) فمجموع هذا الكلام جملة كبرى لا غير ، و(غلامسه منطلق) صـغرى لا غير ، لأنها خبر ، و(أبوه غلامـه منطلق) كبرى باعتبار (غلامهـ منطلق)

وصغزى باعتبار (جملة الكلام)(r).

كمـا أذاع ابـن هشـام انقسـام الجملـة الكبـرى إلى ذات وجـها، وإلى ذات ذات

وجهين.

فذات الوجهين هـي: اسمية الصدر وفعلية العجز نحو: (وزيد يقوم

أبوه) أو شرطية العجز أو صدرها حرف مشبه بالفعل غير مكفوف، والخبر جملة فعلية أو شرطية أو صدرها فعل مسند إلى جملة اسمية، أو فعل ناستخ خبره أو مفعوله الثاني جملة اسمية أو شرطية. وذلك نحو: الجريح يستغيث،

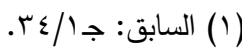

$$
\begin{aligned}
& \text { (Y) انظر : مغني اللبيب ج/r/r) }
\end{aligned}
$$




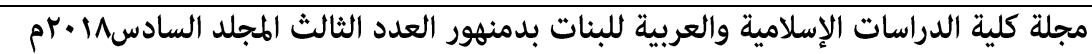

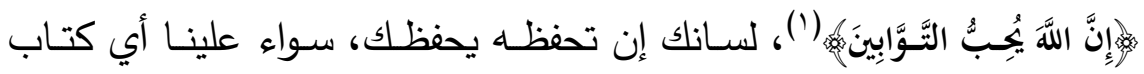
قرأت، تبين لي أيكم صادق، ما يزال العلم في طلبه خير، كان هرم متى، لقي زهيرًا أكرمه، رأيت الغدر من يقربه يندم.

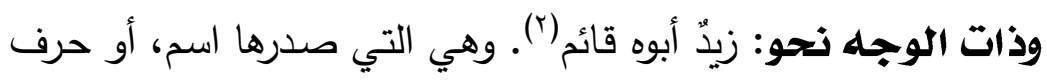
مشبه بالفعل غير مكفوف، والخبر جملة اسمية، أو صدرها فعل مسند إلى جملة فعلية، أو فعل ناسـخ خبره أو مفعولـه الثاني جملـة فعليـة. وذلك نحو : الفضل خيره واسع، إن قلبك فيه إيمان، بدا لنا كم صبرتم، بات الطفل يلعب،

لا تظني التواكل يغنيك(r).

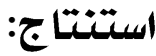

ا- وضعت الجملة العربية تحت معيار الإسنادية حيث قيدها سيبويه والخليل في باب المسـند والمسـند إليـه بـذلك وهي التي يلـزم تكوينها مـن ثلاث عناصر في: أ- المسند إليه (المبتدأ- الفاعل - نائب الفاعل).

$$
\text { ب- المسند (الخبر - الفعل). }
$$

ج- الإسناد وهو الرابطة بين الجزأين السابقين، إذ هو الحكم بين أجزاء الكلام،

$$
\text { وهو عنصر معنوي. }
$$

r- التراكيب الإسنادية التي انشقت من الجملة العربية ثنائية التقسيم فإذا كانت مصدرة بالاسم فهي الجملة الاسمية، وإذا كانت مصدرة بفعل فهي الجملة الفعلية. وضـع هذا المعيار أيضًا سيبويـه والنحاة من بعده. r- تأخذ الجملة الإسنادية ثنائية التقسيم تفريعات أخرى بحسب إطارها العام وبحسب ما بداخلها من جمل. 


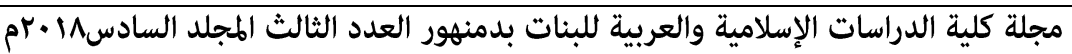

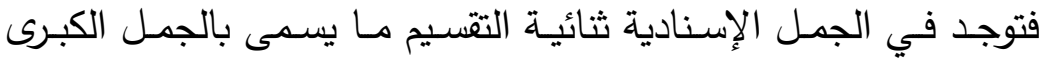
والجمل الصغرى فهي بالأكيد تتنمي إلى القالب الثنائي. فالكبرى هي الاسمية التي خبرها جملة أو الصغرى المخبر عنها فهي المبنية على المبتدأ.

والمبنية على المبتدأ قد تكون فعلية أو اسمية نحو: (زيد قام أبوه) و(زيد أبوه قائم) فالجملة إذا كبرى وصغرى باعتبارين ليكون المسئول عن هذا التقسيم ابن هشام وكذلك يوجد عند الجملة ذات الوجهين اسمية الصدر وفعلية العجز أو شرطية العجز . أو صدرها حرف مشبه بالفعل غير مكفوف، والخبر جملة فعلية أو شرطية أو صدرها فعل مسند إلى جملة فعلية.

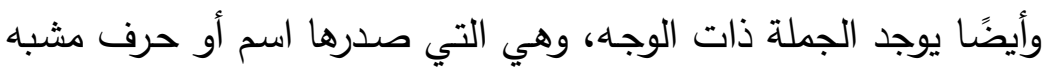

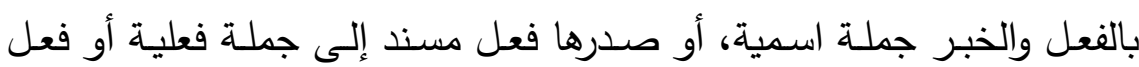
ناسخ خبره أو مفعوله الثاني جملة فعلية. أما في النهو الثحليث: اعتبر المحدثون هذا النوع في الأشكال النمطية المكونة للجملة الاسمية واختلاف العلاقات القائمسة بين عناصـرها وأطرافها سببا دافعـا للقيام بمحاولة إعـادة تصنيف هذه الأشكال بغيـة تحقيق قدر مـن التماثل بين المجموعـات المتميزة فيها.

فقالوا بعدد من التقسيمات الضرورية لتوحيد النسق في الأقسام واطراد العلاقات الرابطة بين مكوناتها، وبسبب الخبر إلى ما كان مفردًا، وما كان جملة، وما ألحق بأحدهما، ومن حيث المرفوع الذي يسد مسد الخبر إلى ما وقع فاعلًا وما وقع نائبا عن الفاعل، ثم من جهة العلاقات السياقية إلى: ا- جملة أصلية أي مطلقة لم يلحقها النسخ. r- وأخرى محولة أو مقيدة أي منسوخة. 


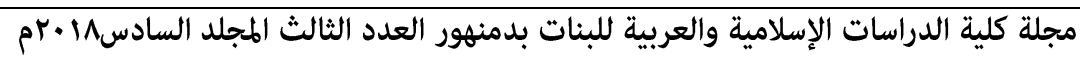
وكلذ لك ما يتصل بالتطابق بين أطرافها إلى: ا - واجبة التطابق.

r- ب وأخرى ممتنعة (1). r- وثالثة جائز الوجهين.

وأخيرًا من ناحيت الترتيب بين هذه الأطراف إلى:

ا - جملة واجبة الترتيب.

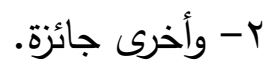

والتحليـل العلمي يؤكد وجود نوع متميز مـن الجملـة العربيـة يمكن أن يصـطلح عليـه (بالفعـل) لا (الجملـة الاسـمية)، ولكنـه - مـن ناحيـة أخـرى يفرض ضـرورة تحديد مدلول هذا المصطلح على نحو مغاير نسبيا لما شاع الأخذ بـه في التراث النحوي، أخذًا بمعطيـات مجموعـة الأسس والاعتبـارات الواجب مراعاتها تلك التي سبق تفصيلها(؟). وحتى يمكن أن يتصف تحديد أنواع الجملة بالصفات الضـروريـة اللازمـة

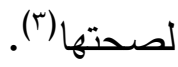

فإنـا يجب أن نمضي في التمييز بين الجملة المكونـة من مبتدأ وخبر وتلك التي تتكون من مبتدأ ومرفوع يسد مسد الخبر إلى غايته، كما يجب أن نأخذ بمقتضـى التقرقة القائمة بين الخبر المفرد أو الجملة من ناحية، والخبر شبه الجملة من ناحية أخرى من حيث ضـرورة التطابق العددي والنوعي في

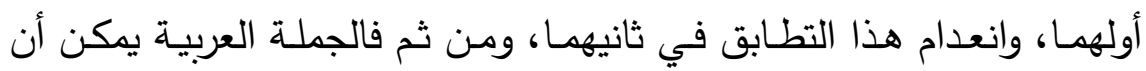
يصطلح عليها بالجملة الوصفية. 


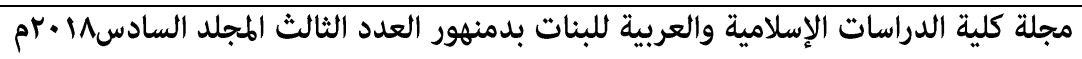

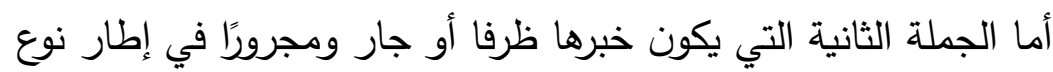
مستقل أيضًا من أنواع الجملة العربية، فهي (الجملة الظرفية). وهكذا نقصر مدلول الجملة الاسمية على ما كان المسند فيها واحدًا من ثلاثة: (الاسم الجامد)، غير المشتق، (الاسم المشتق) الذي لا يصـ كونـه رافعا للمسند إليه، (التركيب الإسنادي) أو ما يصطلح عليه في التراث النحوي بالجملة (1).

\section{هذا وقد اعتمل أحلد الباحثين المحلدين في تقسيه الجملتّ} على تعريف (بلـو مفيـد) وهو لالجملة: شكل لغوي مستقل ليس متضمنًا في شكل لغوي أكبر وفقا لمقتضيات التركيب النحويه(؟). وبناء عليه: تنقسم الجملة إلى قسمين كبيرين (r):

القسبـه الأول: الجملة الكبرى، وهي: مـا تكونت مـن تركيب مستقل واحد على الأقل يتألف من طرفين أولهما المسند إليه وثانيهما المسند نحو: العقاد شاعر ، فالكلمة (العقاد) تشغل موقع المسند إليه والكلمة (شاعر) تشغل موقع المسند.

القسيه الثـاني: الجملة الصغرى، وهي: ما تكونت في شكل يختلف عن الجملة الكبرى بمعنى أنها لا تتكون من تركيب مستقل.

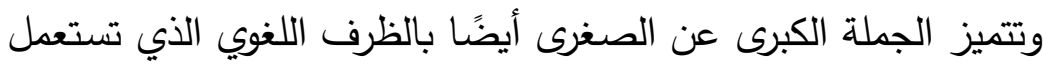
فيه وذلك أن الجملة الكبرى يمكن أن تظهر بشكلها الراهن دون أن تتوقف على نطق سـابق كسؤال تكون إجابـة عنه في حين أن الصـغرى لا تظهر بشكلها

(1) انظر : الجملة الاسمية صد.ب، للدكتور على أبو المكارم، مؤسسة المختار للنشر - مصر - القاهرة،

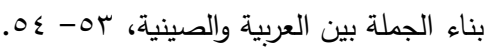

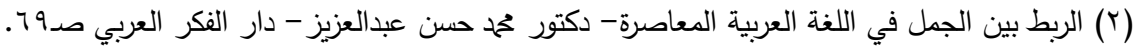

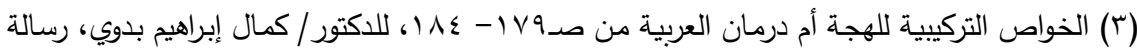

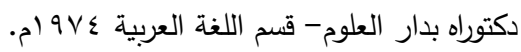


الإسناد والجملة العربيةبين القدامى والهداثين دراسة تحليلية مقارنة )

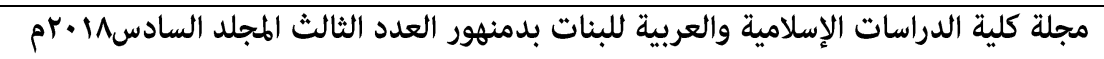

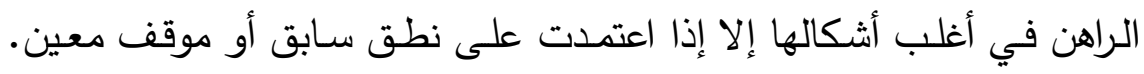
ومن أمثلتها

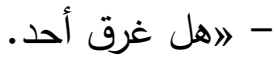

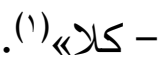

فكلا في المنطوق الثاني جملة صغرى، لأنها تتوقف على نطق سابق

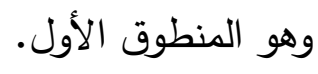

\section{أقسام البمهلة الكبرى}

تتقسم الجملة الكبرى في نظر الدارسين المحدثين إلى ثلاثة أقسام:

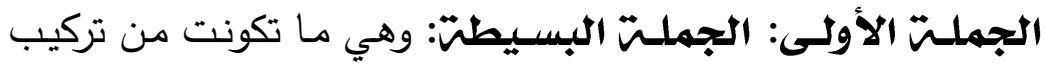

$$
\text { - مستقل نحو: حضر كحمد. }
$$

والمثال الأول يتكون من تركيب فعلي، والمثال الثاني يتكون من تركيب اسمي. 
الإسناد والجملة العربيةبين القدامى والهحدثين دراسة تحليلية مقارنة )

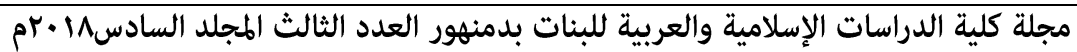

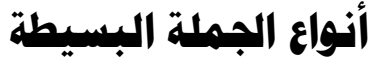

\section{وعناصرة ألها الأساسية}

"للجملت البسيطت ثلاثن أنواع|'):

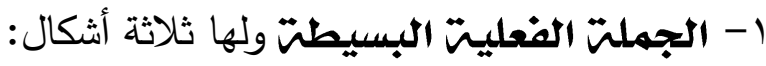

أ- التي تتكون من فعل لازم وفاعل مثل: انهزم الباطل.

ب- التي تتكون من فعل متعدي وفاعل ومفعول به مثل: خلق الله الكون. ج- التي تتكون من فعل مبني للمجهول مثال: 》قضي الأمر «.

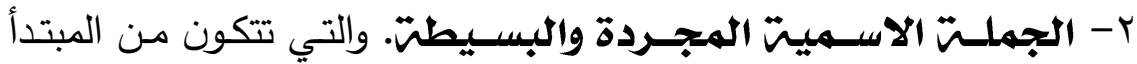

$$
\text { والخبر نحو: (العدل حق). }
$$

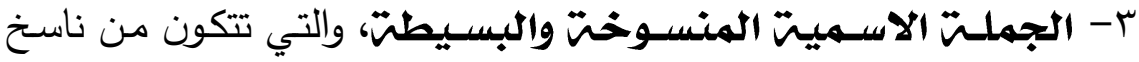

$$
\text { واسمه وخبره نحو: ليس الجبن صفة حسنة. }
$$

ويلاحظ: أن الجملة البسيطة ترد بأساليب مختلفة في: الإثبات والنفي، وحهن

والتأكيد والاستفهام والتعجب والتشبيه والاستدراك، والتتني، والترجي.

كما يالاحظ: أن الجملة التي يكون فيها الخبر شبه جملة، هي جملة

بسيطة؛ لأن الخبر في الحقيقة ليس هو شبه الجملة بل هو محذوف تقديره

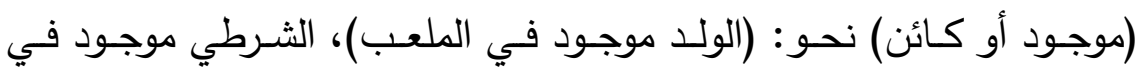
(الميدان)

الجملت الثانيتّ: الجملتش المعطوفتّ: وهي ما تكونت على الأقل من تركيبين مستقلين لا يعتمد أي منهما على الآخر ، وقد يتم الربط بينهما بأداة

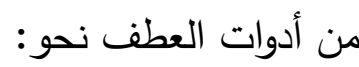
- انهمل مطر غريب ثم تساقط وابل من البرد.

(1) انظر: الجملة العربية- مكوناتها - أنواعها- تحليلها، للدكتور محمد إبراهيم عبادة، ناشر ، مكتبة الآداب

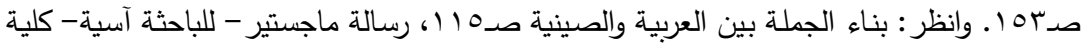




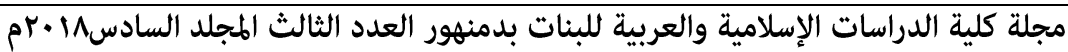
فالمثال جملة معطوفة تتألف من تركيبين مستقلين هما:

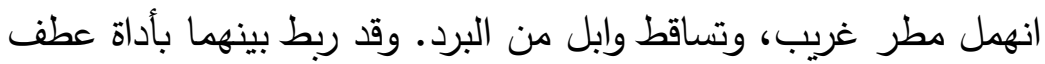

$$
\text { هي (ثم)(') }
$$

الجملة الثالثتّ: الجملثة المركبشت: وهي ما تكونت من تركيب مستقل وتركيب أو أكثر غير مستقل، وقد يربط التركيب المستقل والتركيب غير المستقل بأداة من أدوات الربط المعروفة في الجملة المركبة، نحو: مضت أيام المأتم الثلاثثة والأسرة في ذهول. فالمثال السابق جملة تتألف من تركيبين، تركيب مستقل وتركيب غير مستقل.

فالتركيب المستقل هو : (مضت أيام المأتم الثلاثة).

$$
\text { والرابط هو: والتب غير المستقل هو : (الأسرة في ذهول). }
$$

وقد يكتفى بالربط السياقي نحو: ماتت الرغبة يوم لاحت أنها حرام(؟). فالمثال السابق جملة تتألف من تركيبين تركيب مستقل وتركيب غير

مستقل. - مستر

$$
\text { فالتركيب: (ماتت الرغبة يوم) تركيب مستقل. }
$$

والرابط بينهما سياقي وهو وقوع التركيب الثاني في حال تضام مع

$$
\text { الكلمة يوم التي تتطلب ما يخصصها ويحددها. }
$$

فإذا تكونت من جملتين بسيطتين فيصطلح عليه بالتركيب المفرد.

وإذا تكونت من أكثر من جملتين فيصطلح عليه بالتركيب المتعدد.

والجملة المركبة أحد عناصرها الأصلية الأساسية، أو المتممة جملة

فعلية، أو اسمية، أو مصدر مؤول. نحو: العلم يهدي إلى المعرفة، ونحو: شاهدت أزهارًا قطوفها دانية، يجب أن أزروك. مدوك. 
الإسناد والجملة العربيةبين القدامى والهحدثين دراسة تحليلية مقارنة )

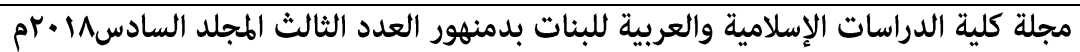

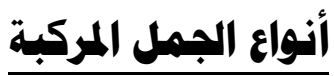

الجمل الهركبنت ثلاثن أنواع:

ا- الجملة الفعلية المركبة من جملتين، نحو: رأيت زيدًا يقضي بالحق.

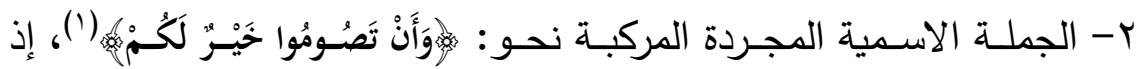
التقدير (صيامكم خير لكم).

ب- الجملة الاسمية المنسوخة المركبة نحو: (إن العدل أن تتطق بالحق).

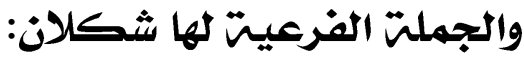

1- الجملة الفرعيـة المصدرية: بحيث ترتبط بالجملـة الأصسلية بأحد الأدوات الآتية: (أن) نحو ينبغي لك أن تسافر (فينبغي) جملة أصلية (أن) رابط،

$$
\text { و (تسافر) فرعية. }
$$

(لـو) (أود لـو تسـامحني) أود جملـة أصـلية فجملـة والأداة (لو) ربطـت

$$
\text { الأصلية بالفرعية (تسامحني). }
$$

Y- الجملـة الفرعيـة غير المصـدرية بحيث ترتبط بالجملـة الأصـلية بضـمير نحسو: (الأزهـار قطوفهـا دانيـة) الأزهـار جملـة أصـلية ارتبطـت بالجملـة

الفرعية بالضمير الهاء (r).

استتنتاج:

يلاحـظ أنـه قد يتفق مسـىى التركيـب الجملـي في الدراسـات اللغويـة (النحويـة) الحديثة مـع الدراسـات النحويـة القديمـة؛ إلا أن لكل منهمـا مفهومـهـ الخاص.

فقد تبين لنا اشتراك مسمى (الجملة الكبرى)، و(الجملة الصغرى) كقمم من أقسام التراكيب الإسنادية في التقسيم الثنائي القديم والحديث كما وضع عند ابن هشام وكان مقصده: التركيب الاسمي الذي يخبر عنه بجملة أمـا مقصده 


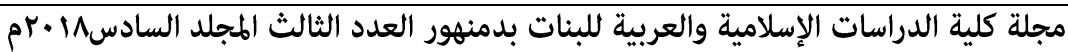
في الدراسات الحديثة فقد اختلف ومن ثم كان تكوينها مختلف عن القديم نظرًا لأنـه صـاحب اتجـاه مغـاير للقديم حيـث اعتمـد تقسيمه على تعريـف غربـي للجملة، وهو تعريف بلومفيد.

وهـذا شـأن الدراسـات الحديثة فغالبـا تكـون متأثرة بالدراسـات الغربيـة الحديثة في تجزيء التراكيب والمراد بها، كما يلاحظ أن ما اتفق مع ابن هثام في المراد بالتركيب هو (الجملة الفرعية) غير المصدرية فقد مثل لها (بالأزهار

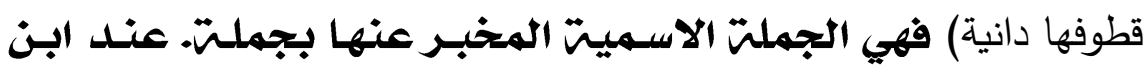
هشاهر. وتسمى عنده الجملة ذات الطرفين.

هـدا وقـد نقـد اندكتورإبـراهيه أنـيس تقسيم النحاة لأجزاء الكـلام. وارتضـى تقسـيمًا رابعًا: الاســ، والضـمير ، والفعـل، والأداة مدـا يـؤذن بتغيير في تقسم الجملة العربية. ثم عدل عن هذا كله، وشُغِل بدراسة نظام الجملة في إطار تقسيم النحاة القـدماء مهتمًا بوضـع المسـند إليـه في الجملـة، والوصـل والفصـل، وموضـع المتعلقات في الجملة( )

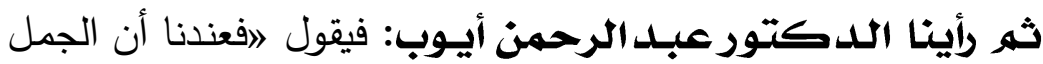
في العربية نوعان: (إسنادية) و(غير إسنادية) والجمل الإسنادية تتحصر في (الجمل الاسمية) و(الجمل الفعلية). أمـا الجمل غير الإسـادية، فهي (جملـة النداء وجملة نعم وبسٔس وجملة التعجب)، وهذه لا يمكن أن تعتبر من الجمل الفعلية لمجرد تأويل النحاة لها بعبارات فعليةه(r). فهو بهذا التصنيف يعيد تقسيم الجمل إلى نوعين إسنادية وغير إسنادية لتتشكل التراكيب في التراث اللغوي من جديد، وقد اتفق معه في هذا التقسيم (1) انظر : من أسرار اللغة آجr فما بعدها. وانظر العلامة الإعرابية في الجملة في القديم والحديث صـ .0r -01

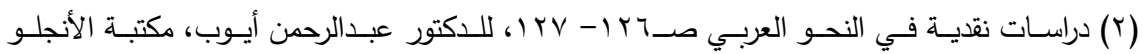

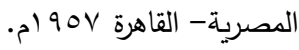




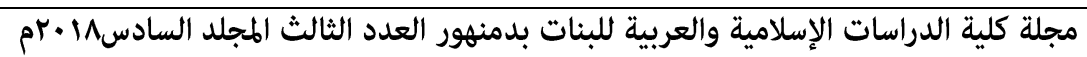
الاكتور عبداللطيف حماسة على ما سنرى، ويعد هذا أول نموذج اختلاف في النحـو الحـديث حيـث خـرج فيـه أصـحاب هـذا المـذهب عـن الإطـار القـديم لتصنيف الجملة العربية فلم تعد إسنادية فحسب مثلما كانت في التراث النحوي بل أصبح فيها ما ينتمي إلى الإسناد كما أصبح فيها ما لا ينتمي إلى الإسناد.

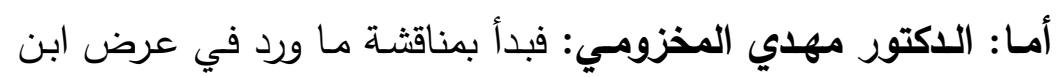

$$
\text { هشام، وقد أبدى مخالفته في عدة نقاط: }
$$

أولهـا('): أنـه اعتبر الجملـة الاسمية أساسًا للجمل العربية، ولهذا قدم

$$
\text { ذكرها على حد مأخذه ومأخذ غيره في معالجة مثل هذه الأمور . }
$$

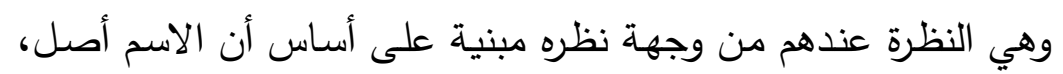
والفعل فرع. لأن الاسم عند ابن هشام والبصرين أصل المشتقات، فمن المقرر عندهم أن المصدر - وهو اسم- أصل المشتقات جميعًا. وليس بصحيح. ثانيًا: ارتباكه في الامثلة التي جاء بها نماذج للجملة الاسمية. فهيهات عنده اسم، لأنـه يسمى عنده: اسم فعل، وهو بعيد عن الاسمية؛ لا يقبل أيسة

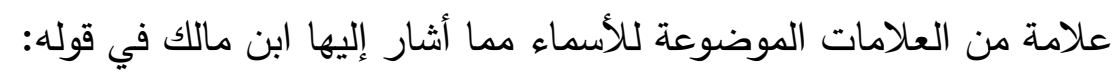

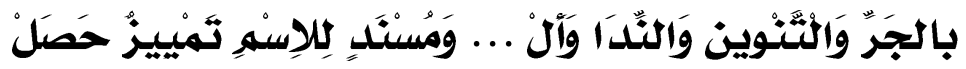

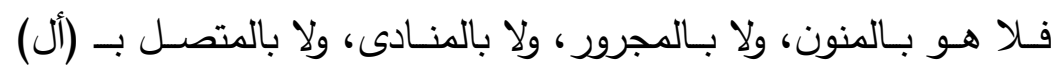

$$
\text { ولا بالمسند إليه أبدًا. }
$$

ثالثًا: أن هيهات في رأي مدرسة الكوفة فعل حقيقي كسائر الأفعال. لربعًا: تمثيله للاسمية بقوله: (قائم الزيدان) فغير موفق فيه، لأنها ليست

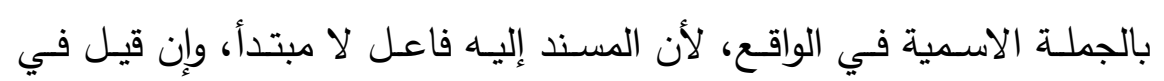

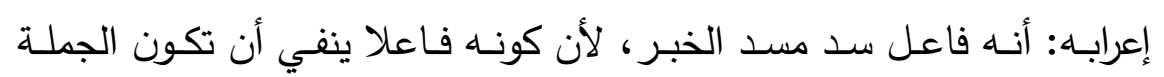




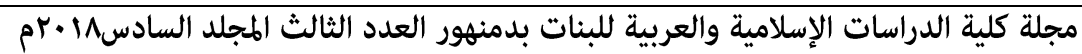
ويوجه الدكتور مهدي المخزومي اعتبار ابن هشـام والبصـرين الاسـم أصل للفعل يعد مخالفته للأصل؛ لأن الفعل في اللغات السامية ومنها العربية هو كل شيء، وأساس التعبير ، واعتبار المصدر أصل المشتقات- ما هو - إلا مظهر من مظاهر التأثير الآري في العربية، لأن المصدر في الآريـة، أو في اللغات الهندية الأوربية هو أصل المشتقات جميعًا.

ثم رأى أنه يلزم الاتفاق مع القدامى في التسمية إلى اسمية وفعلية تمشيًا

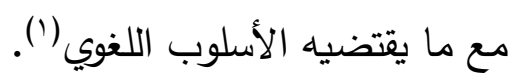

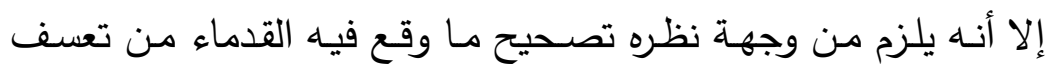
وارتباك محاولة منهم إلى تفريق يدخل في كلا القسمين ما هو منه ويخرج من كليهما ما ليس منه على حد رؤيته. فعنده: أن الجملة الفعلية هي: الجملة التي يدل المسند على التجدد، أو التي يتصف فيها المسند إليه بالمسند اتصافًا متجددًا، وبعبارة أوضـح على حد قوله: هي التي يكون فيها المسند (فعلًا) لأن الدلالة على التجدد إنما تستمد من الأفعال وحدها(ب).

وقد استشهد على ذلك مـا جاء في التلخيص للخطيب القزويني: اأما كونه - يعني المسند- فعلا فللتقييد بأحد الأزمنة الثلاثة على أخصر وجه مـع

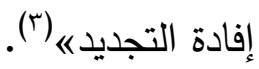

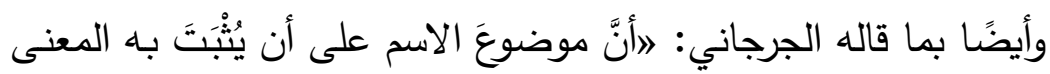

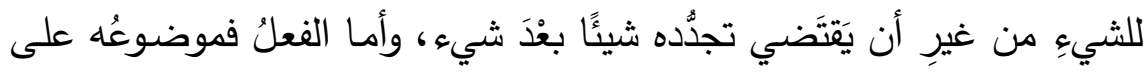

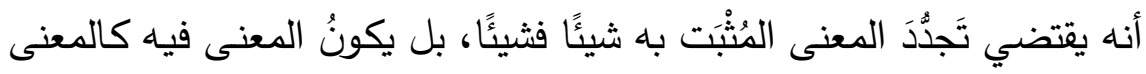
في قولك: "زيـد طويـل، و "عمرو قصير": فكما لا تقصد ههنا إلى أن تَجعل

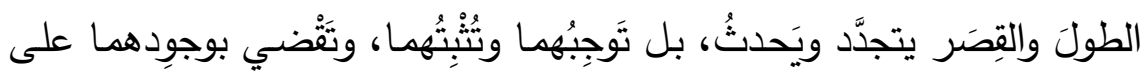

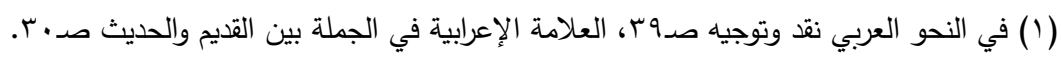

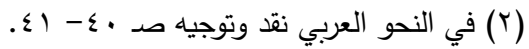

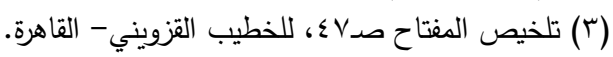




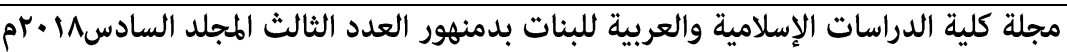

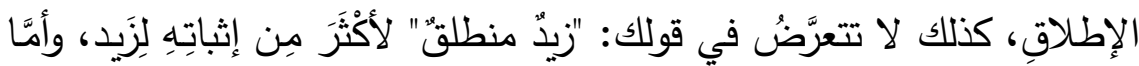

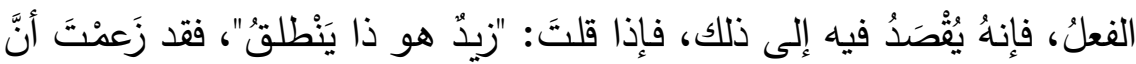

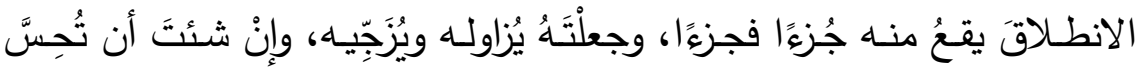

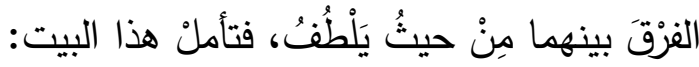

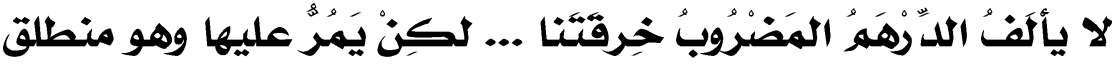

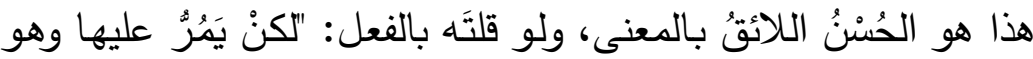

$$
\text { ينطلقُ"، لم يحسنه ('). }
$$

أمـا الجملة الاسمية: فهي التي يدل فيها المسند على الدوام والثبوت،

أو التي يتصف فيها المسند إليه بالمسند اتصسافًا ثابتًا غير متجدد، أو بعبارة أوضح: هي التي يكون فيها المسند اسمًا.

وعلى هذا فعنده (طلع البدر) و (البدر طلع) جملة فعلية.

أمـا الأولهى: فالأمر فيها واضـح، وليس فيـه خـلاف مـع القدماء، وأمـا الثانية: فاسمية في نظر القدماء، وفعلية في نظره. ويسلل لألك: لأنه عنده لم يطرأ عليها جديد إلا تقديم المسند إليه، وتقديم المسند إليه لا يغير من طبيعة الجملة، لأنه إنما قدم للاهتمام به. وهذا عنده: يجنبه من وجهة نظره المشكلات التي أوقع النحاة القدماء أنفسهم فيها، أو أوقعهم فيها منهجهم الفلسفي على حد قوله. فالقول بأنها اسمية يحمله إلى الذهاب إلى اعتبار الاسم المتقدم مبتدأ لا فاعلا، وإذا اصبح مبتدأ خلا الفعل من الفاعل، واضطر الدراس إلى تقدير فاعل، وقد قدروه ضميرًا يعود على المبتدأ، ويحملنا على اعتبار هذه الجملة البسيطة جملة مركبة(r)، فقد أصبحت بعد ذلك الاعتبار، وهذا التقدير مكونة من جملتين، المسند إليه في الأولى هو البدر، والمسند إليه في الثانيـة هو 


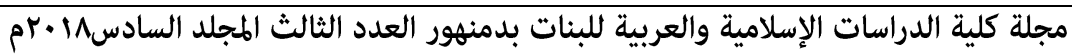
الضمير العائد على المبتدأ، ويحملنا على أن نرجع ثانية فنحوله من كونه مبتدأ إلى كونـه فاعلا إذا دخلت عليه إحدى أدوات الشرط، كأن يقال: إذا البدر طلع كان كذا وكذا، وذلك لأن (إذا) في الشرط لا يليها إلا جملة فعلية، وبكون البدر حينئذ فاعلا، ولكن لا للفعل الملفوظ بـه، ولكنه فاعل للفعل الذي يدل عليه الفعل الملفوظ به، ويكون هذا الفعل واجب الحذف، لا يذكر في حال، ولو ذكر فقيل: إذا طلع البدر كان كذا وكذا لكان من سخيفة ومرذوله، واللغة العربية ودارسوها في غنى عن هذه العمليات الذهنية المعقدة التي لم توضـح معنى ولا فسرت أسلوبا.

وستطرد الدكتور مهدي المخزومي في بيان فكرته بأن الجملة (البدر طلع) هي الجملة الفعلية: (طلع البدر) نفسها، ولم يطرأ عليها تغيير سوى تقيم المسند إليه الذي نسميه في الجملة الفعلية (فاعلً)، ولكنهم منعوا تقديم الفاعل، وأنكروا على من يرى جواز تقديمه، واتهموه بالجهل بالعربية. أو بإفساد النحو، وذهبوا في تعليل منع تقديم الفاعل مذاهب شتى ('). ثم ينتقد لفكرته ابن الانبار في تعليله لمنع تقديم الفاعل: الأن: الفاعل تنزل منزلة الجزء من الكلمة وهو الفعله(ب). ويرى أن ابن الأنباري استدل لتصحيح رأيه في ذلك باستدلالات متكلفة سـيطر عليها المـنهج العقلي سـيطرة أبعدت الدرس اللغـوي عن جو البحـث •اللغوي

ثم انتقد أيضًــا ابن يعيش لقوله بمقولـة ابن الانبـاري ولتعليلـه وجـوب تأخير الفاعل عن الفعل بقوله: اإنما وجب تقديم خبر الفاعل - سيعني الفاعللأمـر وراء كونـه خبـرًا، وهـو كونـهـ عـاملاً فيـه، ورتبـة العامـل أن يكـون قبـل

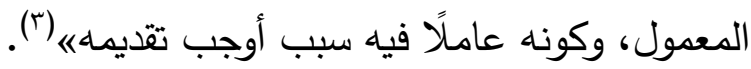




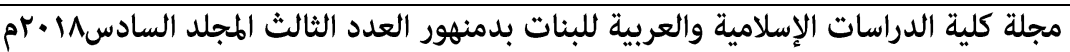
حيث قاس العامل في النحو على العلة في الفلسفة، فلما لا يجوز تقديم المعلول على العلة، لأن رتبة العلة أن تكون قبل المعلول، كذلك لا يجوز تقديم المعمول على العامل، لأن رتبة العامل أن يكون قبل المعمول. ويؤكد فكرته بأن جملة (البدر طلع) فعلية يبعده عن هذه التأويلات

$$
\text { والتقديرات التي لا طائل تحتها. }
$$

على أن تقـديم الفاعـل على الفعـل لـيس ممتــع، كمـا تصـور النحـاة المناطقة وخاصة وأن الكوفيين كانوا يذهبون إلى جواز تقديم الفاعل، وأنهم إنما ذهبوا إلى هذا، لأنهح عثروا من الشواهد على ما يؤيد مذهبهم فقد رووا قول الزباء:

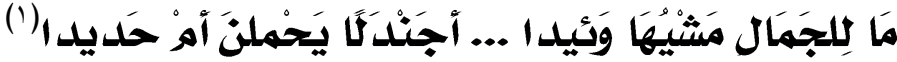
وحين واجهوا بـه البصرين لم يستطيعوا رده، ولكنهم تحيلوا على تأويله

فاعتبار (البدر) فاعلً وهو مقدم، يغنينا عن تقدير ضمير ، ويغنينا عن كل تقدير وتأويل إذا اقترنت الجملة بأداة الثرط، لأن الجملة ما تزال فعلية وأن تقدم المسـند إليـه فيها، وأنها سـياق ملائم للشـرط، وبهذا نتجنـب الوقوع في تأويلات وتقديرات لا فائدة منها إذا فطبيعة الجملة الاسمية تختلف عن طبيعة الجملة الفعلية، وما دام الوضـع كذلك يحسن بنا أن نفرق بين المسند إليه في الأولى، والمسند إليـه في الثانيـة، فنسـي الأول مبتدأ، ونسـي الثاني فاعلًا

سواء أكان الفعل في الجملة الفعلية مبنيًا للمعلوم أم مبنيًا للمجهول(؟). غير أن المسند إليه في الجملة الفعلية عند القدماء نوعان:

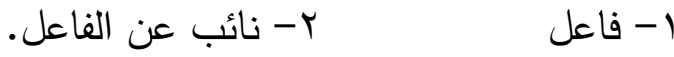

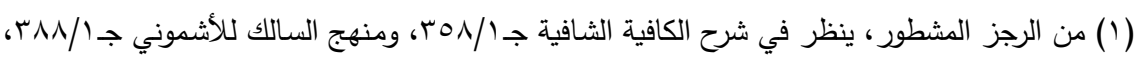

$$
\begin{aligned}
& \text { والتصريح جـ/ / } \\
& \text { شرح المفصل جـ/ ـ ؟ ـ. }
\end{aligned}
$$




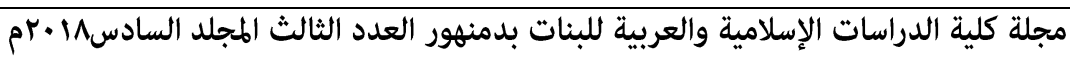
فالفاعل عندهم إنمـا يكـون في الجملـة الفعليـة التي بنـى الفعـل فيهـا للمعلوم، والنائب عن الفاعل عندهم إنمـا يكون في الجملـة الفعلية التي بني الفعل فيها للمجهول، ويبنى الفعل للمجهول بضم أوله، وكسر ما قبل آخره إذا كان الفعل ماضيًا، نحو: حُرِت الأرض ... ولكننا نخالف القدماء، فنزعم أن المسند إليه في كل منها نوع واحد، وذلك لأن كل منههـا مرفوع، ولأن كلا منهما مسند إليه، ولأن كلا منهما يستدعي تأنيث الفعل إذا كان مؤنثًا. ويستدل على ذلك: بأن القدامى يصرحون في أثناء البحث في النائب

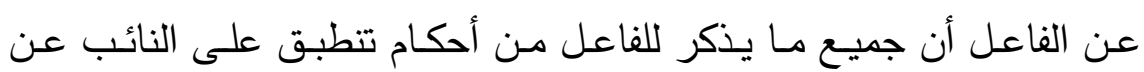

الفاعل. والفرق بين الفاعل والنائب عنه إنما يكون في بناء فعله فقط('). والنحاة مع تمييزهم بين موضوعين من حقهما من وجهة نظره أن يكونا موضوعًا واحدًا، يميزون بين نوعين من الفاعل، فيعرفون الفاعل بأنها: اعبارة عن اسم صـريح أو مؤول بـ أسند إليه فعل أو مؤول به مقدم عليه بالأصسالة

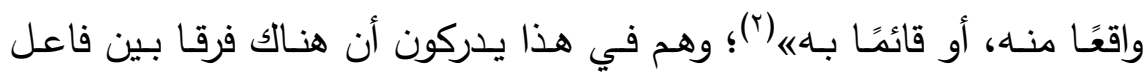

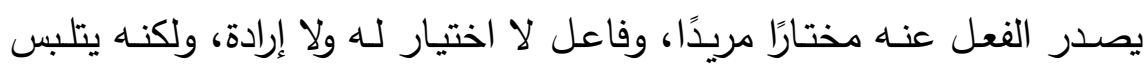
بالفعل ويتصف بـه، ومثلوا لـأول بنحو (سـافر زيد) وزيد هنا مختار في أن يفعل الفعل، أو لا يفعله، ومثلوا للثاني بنحو (انكسر الإبريق)، فالإبريق غير مختار في الانكسار، ولا مريد لـه، ولكنه يتلبس بـ تلبسًا قسريا، وإدراكهم هذا الفرق سليم. ثم يوضـح ليتهم دارسوا الموضوعين جميعًا: الفاعل والنائب عن الفاعل في هذا الضوء، ولو درسوهما كذلك لانتهوا من وجهة نظره إلى نتيجة سليمة، ولجنبوا الدارسين متاعب هم في غنى عنها ولقدموا لهم موضوعًا واحدًا بداًا من موضوعين. 


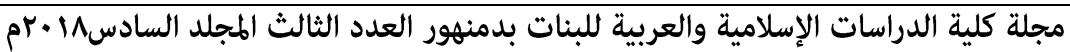

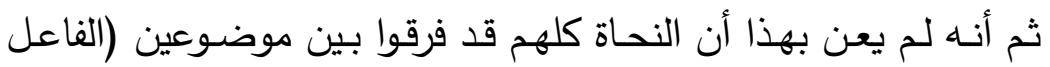

$$
\text { والنائب عنـه) من حقهما أن يكونا موضوعًا واحدًا ('). }
$$

واستشهد بأن سيبويها لم يفرق بينهما أثناء معالجته موضوع الفاعل حيث قال في معرض الحديث عن الفاعل والنائب عن الفاعل: لهذا باب الفاعل الذي لم يتعدّه فعلُه إلى مفعول، والمفعول الذي لم يتعد إليه فِعْلُ فاعلٍ؛ ولم يتعده فعلُه إلىى مفعول آخَر ، والفاعل والمفعول في هذا سَواء، يَرتفع المفعول

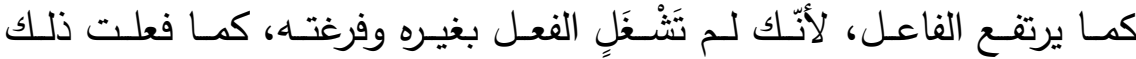

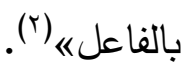

وكذلك الرضـي حيـث نقـل الرهـا لـم يسـم فاعلـه وهـو عنـد عبـدالقاهر

$$
\text { والزمخشري فاعل اصطلاحًا (r). }
$$

واستند في تسويته بين البابين في باب واحد بأن هذه التسوية بين الفاعل والنائب عن الفاعل مبنية على أسـاس من فهم لطبيعة التركيب، ومن استتاد إلى نقول عن أسـانيد كان النحاة الآخرون قد استمدوا منهم أصـول دراستهم،

$$
\text { وكانوا عيالاً عليهم. }
$$

ومن ثم استقر التقسيم عنده إلى: فعلية واسمية مستهدى في هذا التقسيم هذه الطبيعـة اللغويـة الذي انتهى بهـا إلى أن المسـند إليـه في الجملـة يسـى إسى فاعلا سواء أكان الفعل مبنيًا للمعلوم أم مبنيًا للمجهول وبهذا يخلص من إفراد باب مستقل، يسمونه النائب عن الفاعل.

فعنده إذن: (النائب عن الفاعل) (فاعل) أيضًا، وهو : فاعل لم يصدر عنه الفعل بل تلبس باه تلبسًا، وهو فاعل لغويًا يترتب عليه كل ما يترتب على الفاعل من كونـه مسندًا إليه، وكونـه مرفوعًا، وكونـه يقتضـي تأنيـث الفعل إذا

$$
\begin{aligned}
& \text { (1) في النحو العربي نقد وتوجيه صد؟ ــ (1) }
\end{aligned}
$$

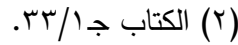

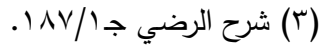




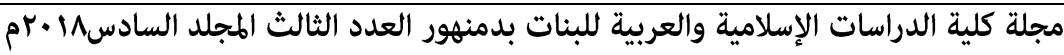
كان مؤنثًا، وهو فاعل من النوع الثاني الذي أشاروا إليه في تعريف الفاعل، هو فاعل قام بالفعل، وتلبس به، ولم يفعله.

فبموازنة بين مثالين: (انكسر الزجاج) و (كُسرَ الزجاج) ظهر أن المسند إليه في كل منهما فاعل، فلم تكد تحس بالغرق بينهما، فكلاهما مما لا إرادة لله، ولا اختيار وكلاهما مما قام بالفعل قيامـا اضطراريا، وكلاهما من وجهة نظر المنطق قد وقع عليه الفعل، ويسمونه في الجملة الثانية نائبًا عن الفاعل. وهذه التسمية من وجهة نظره: فرضها المنهج العقلي عليهم فرضـا، أما المنهج اللغوي فيسوي بينهما، لأن كلا منهما مسند إليه. وبناء عليه: يلزم في إطار هذا المنهج اللغوي الجديد أن يغض النظر عن كل ما قدمه القدامى من اعتبارات لا تمت إلى الطبيعة اللغويـة بصلة. أن ينسى الفصل بين بابين هما في الواقع اللغوي باب واحد('). ومن ثم تستقر القاعدة الجديدة وهي:

أن الجملش الفعليتّ: ما كان (المسند) فيها (فعلا)، سواء اتقدم المسند إليه أم تأخر، تغيرت صورة الفعل أم لم تتغير • إذن فقولك: (طلع البدر، والبدر طلع، وانكسر الزجاج، وكُسرَ الزجاج)، كلها من الجمل الفعلية. والمسند إليه في كل منها فاعل. إلا أن الفاعلين في الجملة الفعلية ضربان: ضرب يفعل الفعل عن إرادة واختيار ، كقولك سافر خالد، وخالد سافر • وضـرب يتلبس بالفعـل تلبسًـا، ولـيس لـه في الفعـل إرادة، ولا اختيـار كقولك: انكسر الزجاج، وكُسرَ الزجاج. وما دام الفاعلون ضربين، فلابد من تغيير صورة الفعل تغييرًا يعبر عن الفرق بين هذين الضربين. 


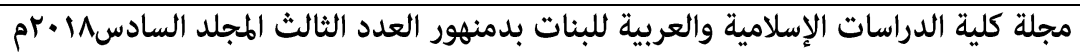

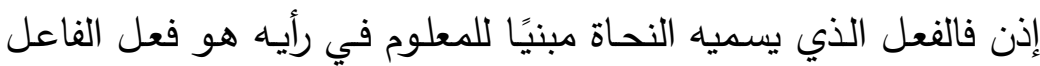
المختار والفعل الذي يسمونه مبنيًا للمجهول في رأيه هو فعل الفاعل الذي لا لاختيار له (') وهذا عنده هو البناء القياسي في بناء، الفعل الذي قرره النحاة أنه مبني للمجهول. أمـا البنـاء السـماعي الـذي لا يقـاس عليـه فهـو : بنـاء انفعـل وافتعـل وأشباههما. فهو بـذلك يسـوي بـين الفعـل الـلازم مـن نحـو انفعـل، وافتعـل والمبني للمجهول فُعِلَ في أن كـلا منهمـا في إطسار بـاب الفاعل ولكن في الأبنيـة السماعية. أدلته في ذلك: يؤكد أنـه لا فرق عنده بين (انفعل) وأشباهه و (فُعِلَ) أن العربية حين تطورت إلى لهجات عامية متفرقة، وحين اتخذت هذه اللهجات أسلوبًا جديدًا، ونحوًا جديدًا، نسيت مـا كان النحاة يسمونه مبنيًا للمجهول، واستعاضـت عنه بصيغة انفعل، وافتعل.

فالمصـريون حين يريدون إلـى القول بأن فلانًا (قُتِلَ)، يقولـون: اتقَتَّل، والعراقيون يقولون انقِتَل، وهو إحساس عميق منهم أن النائب عن الفاعل إنما هو فاعل مطاوع، ولذلك استخدموا بناء فعل المطاوعة.

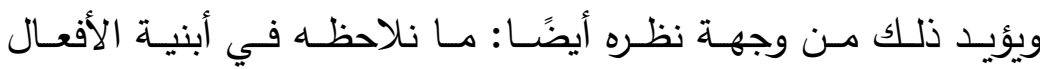
السريانية، فأبنية الأفعال الدالة على بنـاء مـا لم يسم فاعلـه، أو الفعل المبني للمجهول تشبه- إلى حد كبير - أبنية الأفعال العربية الدالة على المطاوعة(r)، وفي اللغة السريانية للفعل المبني للمجهول أربعة أوزان: 


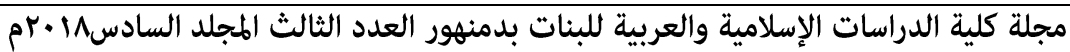

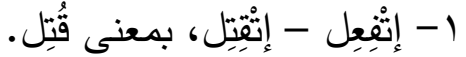

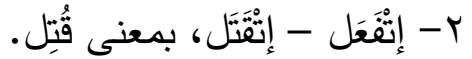

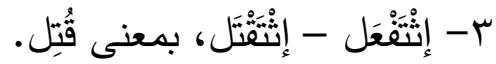

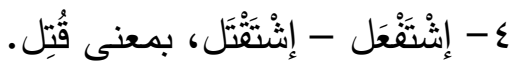

وواضح جدًا ما بين البناءين الأولين، وبناء (افتعل) العربي، كامتنع من

شبه كبير، وإن اختلف عنـه بمكان التاء، فالتاء في الفعل السرياني قبل فاء الفعل، وفي الفعل العربي بعدها، ولا يغير مثل هذا الاختلاف ما بين البناءين من شبه مـادام لكلتا اللغتين السـاميتين سبيلها الخاصـة في البناء والتركيب.

وكذلك الإنجليزية.

مناقشث:

\section{يؤخد على الدكتور مهلدي المخزومسي في تقسيمه للجميلش:}

بأنه لجأ إلى النظر العقلي الذي عابه على النحاة في اعتبارهم كلا من ركني الثرط 》جملة《 ثم أنه بعدما أقر النحاة على تقسيمهم للجملة إلى اسمية وفعلية ووصـفه بأنـه 》تقسـيم صـحيح يقره الواقع اللغويه استـرك في الحسال بقولـه: اولكنهم بنوا دراساتهم اللغوية على غير منهجها، فلم يوفقوا إلى تحديد الفعلية من الاسـية، ووصـف هذا التحديد بأنـه تحديـ سـاذج يقوم على أسـاس مـن التفريق الفظي المحضه وتتمثل سذاجتهم في أنهم عدوا جملة 》البدر طلع《 جملة اسـية وهو يعدها جملة فعلية، لأن الجملة الفعلية عنده هي الالجملة التي يدل فيها المسند على التجدد أو التي يتصف فيها المسند فعلَا (') ويقصد بذلك أنه يجوز ان يتقدم الفاعل على فعله. وقد قال بهذا الرأي قبله الكوفيون

والأخفش (r) - (ب)

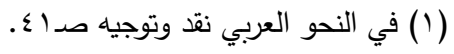

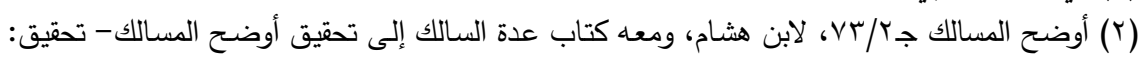

محمد محي الدين عبدالحميد، دار الطلائع. 


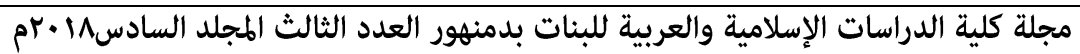

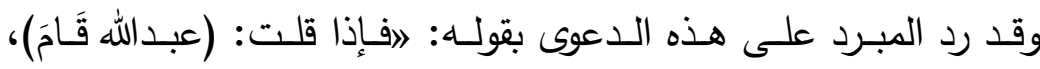
ف (عبدالله) رفع بالابتداء، وقام في موضع الخبر ، وضميره الذي في قام فاعل.

فان زعم زاعم أنه إنما يرفع (عبدالله) بفعله فقد أحال من جهات: منها أن (قام) فعل، ولا يرفع الفعل فاعلين إلا على جهة الاشتراك نحو: قام عبدالله وزيدّ، فكيف يرفع عبدالله وضـيره؟ وأنت إذا أظهرت هذا الضمير بأن تجعل في موضـعه غيره بَانَ لك، وذلك قولك: عبدالله قام أخوه، فإنمـا ضميره في موضع أخيه. ومن فساد قولهم أنك تقول: رأيـتُ عبدالله قام، فيدخل على الابتداء ما

$$
\text { يزيله، ويبقى الضمير على حاله. }
$$

ومن ذلك أنك تقول: عبدالله هل قام؟ فيقع الفعل بعد حرف الاستفهام، ومحال أن يعمل ما بعد حرف الاستفهام فيما قبله. ومن ذلك أنك تقول: ذهب أخوك، ثم تقول أخواك ذهبا، فلو كان الفعل عاملًا كعمله مقدمًا لكان موحدًا، وإنمـا الفعل في موضـع خبر الابتداء رافعًا للضـير -كان - أو خافضًا أو ناصبًا فقولك عبدالله قائم بمنزلة قولك عبدالله

$$
\text { ضربته، وزنيد مررت بهی ('). }
$$

ويوافق حماسـة المبرد والنحاة في أن الاسم المتقدم يعرب مبتدأ والفعل الواقع بعده جملة في الأصل وقعت موقع الخبر وقامت بوظيفته على سبيل

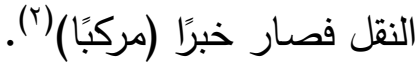
وقد سوى الدكتور مهدي المخزومي بين ثلاثة نماذج تحت اسم الجملة الفعلية. (طلع البدر والبدر طلع، وانكسر الزجاج وكسر الزجاج) كلها من قبيل الجمل الفعلية والمسند إليه في كل منها فاعل ورأى أننا في حاجة إلى إفراد 


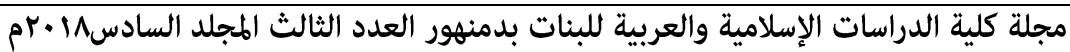
النماذج في كل منها على حده، لا إلى ضمها تحت نموذج واحد نضطر معهد إلى التأويل والافتراض.

أما تحلديله للجملم الاسهيش فلم يخرج عن إطار النحاة القدامى، افهي التي يدل فيها المسند على الدوام والثبوت، أو التي يتصف فيها المسند إليه بالمسند اتصـافا ثابتًا غير متجدد، أو بعبارة أوضـح هي التي يكون فيها المسند اسمًا

ويؤخذ على المخزومسي أنه لم يصنف الكلمـة، ولم يبين أجزاء الكلام ومن ثم نتسـاءل مـع الدكتور حماسـة: هل كل الأسـاء تصلح لإفادة الثبوت وعدم التجدد إذا أخبر بها عن اسم ما؟ وإذا كان اسم الفاعل يدل على التجدد والحدوث كما يقول النحاة(')، فهل إذا أخبرنـا بـه عن اسم مثل: (عحمد قائم) كانت هذه الجملة فعلية عند الدكتور المخزومي، أو اسمية؟ أبهاء فترى أنه خلط بين (حمد قائم) و(ححم جميل) أو (ظريف) لأن المبدأ في الفعليـة عنده إذا كـان المســد فعـل أو يفيد التجدد والحـدوث. فالأسـئلة التي والتي

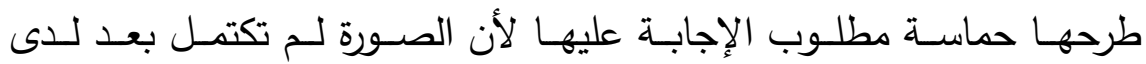
المخزومي.

وبناء على منهجه (خحم قائم) فعليه للتجدد والحدوث مثله في ذلك الجملة التي مسـدها فعل مثل (طلـع البدر) و(البدر طلـع) فلم يخـرج إذن للاسـمية إلا صورة واحدة وهي ما كان المسند فيها اسمًا نحو ححم ظريف وهي في نفس الوقت تدل على الثبوت والدوام، ومن ثم يُنتقد مذهبه بأن المخزومي في دراسته للجملة، كان يعتمد على أساسٍ ما، ثم ينقضه إذا لم يطرد لله في غيره.

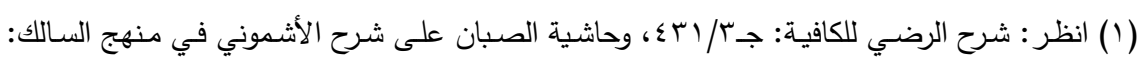

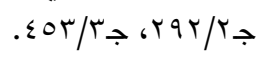




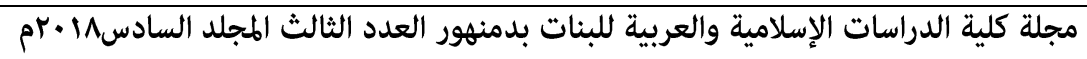

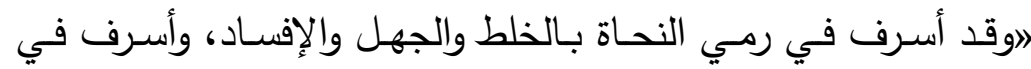
نقدهم دون أن يقدم البديل في الحالات، وكان لأشبه بـه أن يحترم لهم وجهة

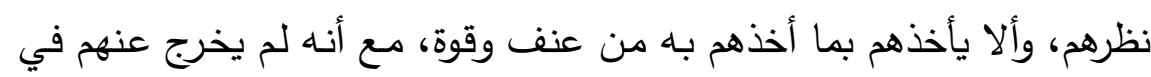
كثير اللهح إلا ما سماه "مركبًا لفظيًا" وقف بـه في مرحلة غير محددة فلا هو جملة إسنادية ولا هو جملة غير إسنادية، ولا هو استقصى كل هذه النمـاذج وصنفها بحيث يستقيم لله ما يربده (1). أما عند حماسله عبد اللطيف: ناقش حماسه ابن هثام في مقالته في تقسيم الجملة آخذ عليه اعتماده

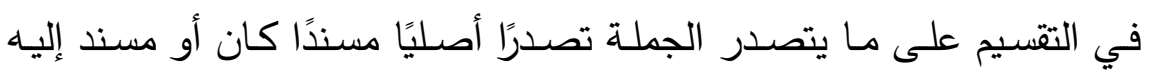
فتعقبه في الأمثلة مشيرًا بالموافقة أو المخالفة.

\section{فتراه يقول في أمثلن ابن هشاهر:}

1- (زيد قائمُ) جملة اسمية. ونحن نوافقه على هذا.

Y- (هيهـات العقيق) جملـة اسـية، أو جملـة فعليـة عند مـن يجعـل أسـماء

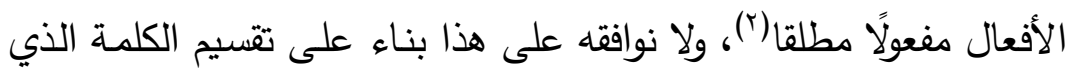
سنشـير إليـه فيمـا بعد، إذ إن هيهات ليسـت اسـًا يمكن أن يوضـح في

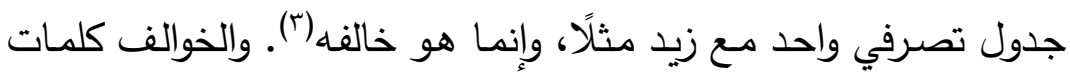
تستعمل في أسـاليب إفصـاحيه، أي في الأسـاليب التي تستعمل للكثف وفو عن موقف انفعالي ما والإفصاح عنه(أ).

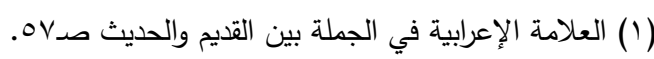

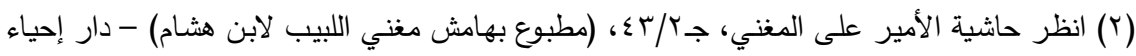
الكتب العربية- القاهرة- دون تاريخ.

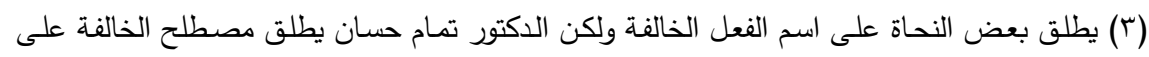

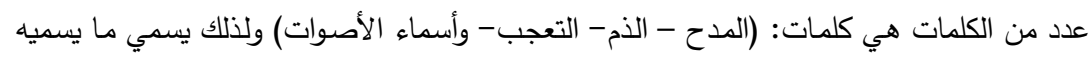

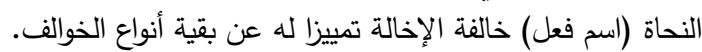

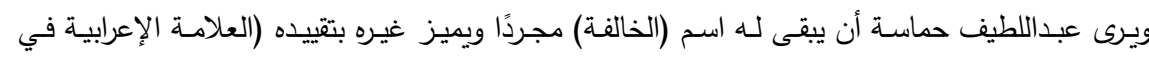

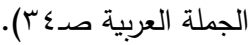
(§) ربما يقصد بهذه اللفظة كما أشار من قبل إلى الجمل (الإفصاحية). 


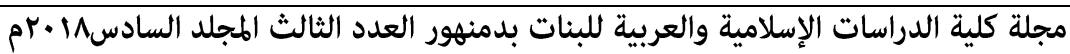
وما دامت الجملة تتسب لصدرها، فهذه الجملة لا يمكن أن نسميها جملة اسمية تقف في صف واحد مـع جملة (زيد قائمُ) ويمكن أن نعدها جملة خالفة من أنواع الجمل المسكوكة(1). ب- (قائم الزيدان) عند من جوزه وهو الأخفش والكوفيون -جملة اسمية- ونحن لا نوافقه أيضًا على كون هذه الجملة اسمية، لأن كلمة (قائم) ليست اسمًا يدل على مسمى، وإنما تدل على موصوف بما تحمله من معنى الحدث

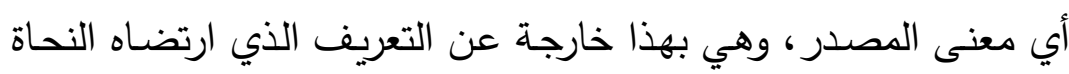
للاسم حين قالوا: 》الاسم ما دل على مسمى"، وما دامت الجملة تتسب إلى صدورها، أمكننا القول بأن هذه الجملة جملة وصفية. ع- (قام زيدُّ) و(ضُرب اللصُّ) و (يقومُ زيدٌّ) و (ظنتت زيدًا قائما) جملة فعلية. ونحن لا نوافقه على كون هذه جملة فعلية لعدة أمور ..... 0- (قم) جملة فعلية، ونحن نوافقه على كونها جملة، ولكنها جملة موجزة بناء

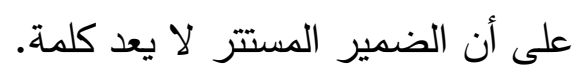
ج- (أفي الدار زيدُ، أعندك زيدُ) جملة ظرفية، ونحن لا نوافقه على كون كل منها كذلك، لأن هذا يحتاج إلى تكلف في التقدير ، لا حاجة بنا إلى شيء

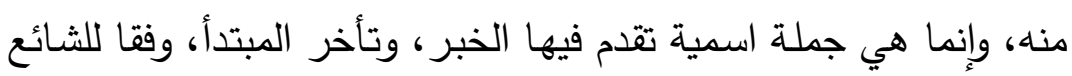
المألوف والصحيح في الوقت نفسه. - (يا عبدالله) جملة فعلية، وهذا مبني على تقدير أدعو عبدالله أو أنادي، أي لابد من الإسناد، ونحن لا نوافقه على هذا وإنما هي جملة ندائية من أنواع الجمل غير الإسنادية. -

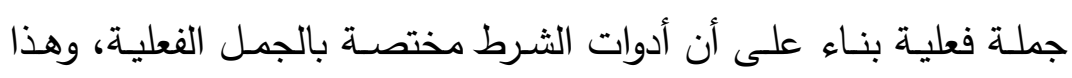




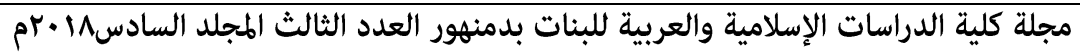

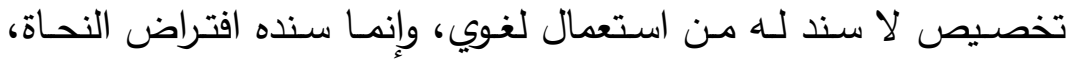

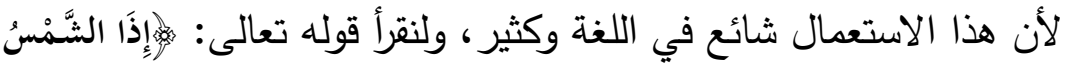

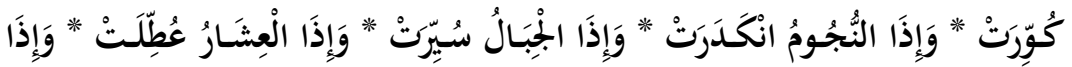

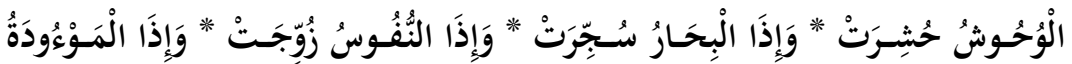

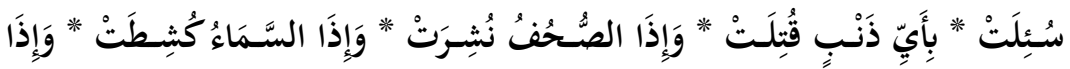

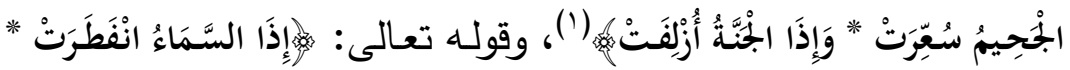

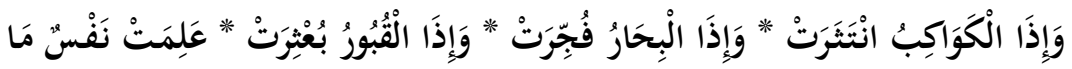

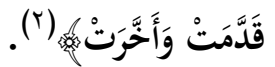
فتراه ينتقد الرضي لقوله: اوإنما لم يحكم بكون (أحد) مبتدأ (واستجارك) خبره لعلمهم بالاستقراء باختصـاص حرف الشرط بالفعليةه(r)، فيرد عن هذا مبراه قائلًا: فأين هذا الاستقراء الذي ثبت عن طريقه اختصاص أداة الشرط بالجمل الفعلية، إذا لم يكن هذا الاستقراء قائمًا على اللغة المستعملة؟ ويقول أيضًا: اونضيف إلى أن استعمال الجملة الاسمية كثير بعد أداة

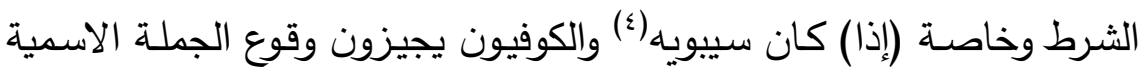
بعد حرف الشرط، بشرط كون الخبر فعلاه(•). وكان أبو الحسن يجيز : الرفح بعد إذا الزمانية بالابتداء في نحو قوله

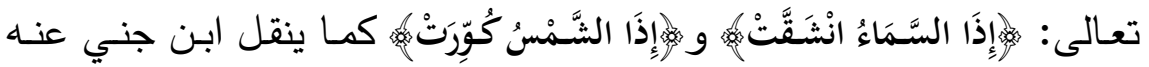
ويصحح مذهبهاب(").

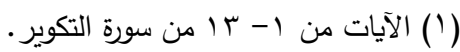

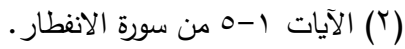

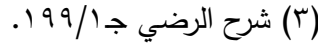

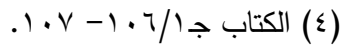

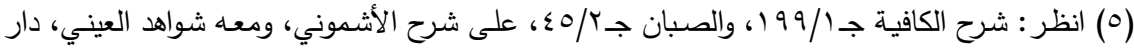

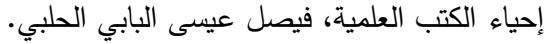

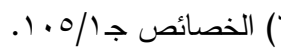




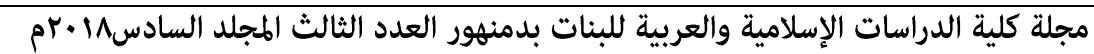
بنـاء على هذا كله يعد هذه الجملـة جملـة اسـمية، لأن تكلف الفعلي والفعلية يخرج العبارة عن ظاهر وجهها دون فائدة وراء ذلك.

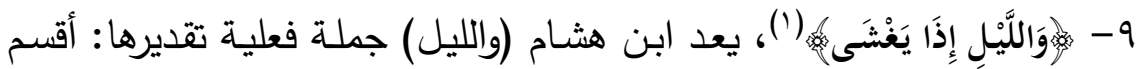
والليل، حتى يتحقق الإسناد، ونحن لا نوافقه على ذلك، وإنما هي جملة غير إسنادية قسمية من الجمل غير الإسنادية(r). كما أنه اختلف مع القدامى في بعض الجمل الأخرى ترددت كلمتهم فيها

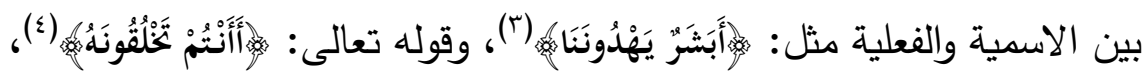
فالصـورة وإن كانتا جملـة اسـية لكن صـدرت باسـتهام والاستفهام في قياس النحساة يغلب دخولـه على الأفعـال لأن الأصـل في الاستفهام أن يكون عمـا يتجدد، والمفيد لذلك أصالة الفعل لذا تراه ينتقد النحاة في هذا بأنه إدعاء منهم لصورة ذهنية يفرضونها وهي قولهم: اأن الأصل في الاستقهام أن يكون عما يتجدد، والمفيـد لـذلك أصـالة الفعـل، فالغالب دخـول الاسـتفهام على الجملـة الفعليةه(0)، ويقول: "إذا وضعنا في الاعتبار أن الآيـة الثانية عطفت عليها

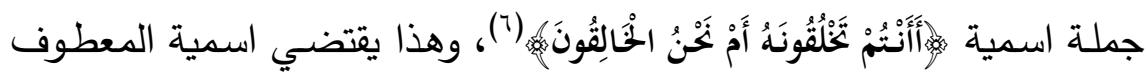
عليه ليتناسب المتعاطفان؛ لم يسلم النحاة بذلك؛ لأنهم يرون أن مرجح الفعلية أقوى، لأنـه أمـر معنـوي بخـلاف مـرجح الاسـية فإنها مجـرد مناسـبة لفظيـة فلا تعارض؛ لأن التعارض لا يكون إلا بين أمرين متساوينهاه(V). 


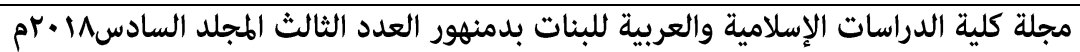
ومن ثم فالجملة العربية من وجهة نظره في حاجة إلى تقسيم بناء على إعـادة تقسـيم الكلمـة، وعدم تعمـيم شـرط الإسـناد في كل جملـة كمـا تصـور (النحاة) (1)

التتيـجت: يظهر من مناقشتة حماسـة لجمل ابن هثام أنه يختلف معه وربمـا مـع النحاة في مذهب الجمهور في تصـنيف الجملـة وتقسيمها وانفراده بتقسيم يخالف النحاة وقد ظهر ذلك من خلال عدم الموافقة مـع ابن هشام في بعض التراكيب. ليخلص من ذلك إلى بناء تصنيف جديد حيث انتقد القدامى في اهتمـاهم الشديد بركني الجملة فهذا الاهتمام الشديد جعلهم يتصسورون أن الجملة لا يمكن أن تتهض إلا بهما. فإذا وجدا استقرت الأمور على الوجه المطلوب، وإذا وجد أحدهما دون الآخر ، وجب تقديره وحسبانه موجودًا . وبناء على ذلك قررت قواعد ترمي كلها إلى المحافظة على ركني الجملة الأساسيين، وعدت جملة ليست إسنادية على الإطلاق في إطار الجملة الإسنادية. لذا قال بفكرته الجديدة في الجملة الموجزة الإسناد. فلـو أن النحـاة مـن وجهـة نظـره اعترفوا بالجملـة التـي يمكن تســيتها بالجملة الموجزة ما وجدوا أنفهه مضطرين إلى كثير لما قيل في هذا المجال. واستتد في فكرته إلى رأي الكسائي حيث أجاز حذف الفاعل مستشهدًا

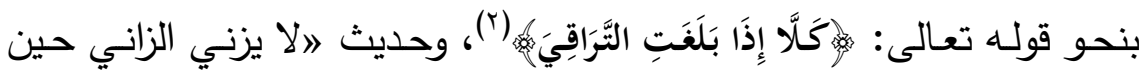
يزني وهو مؤمن ولا يشرب الخمر حين يشربها وهو مؤمنه(ّ). وكلام العربي إن كان غدا فأنتي وغيرها من الأمثلة. 


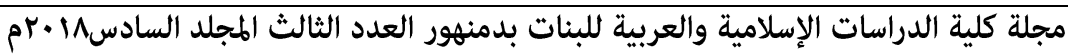

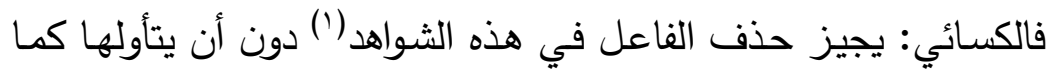
تأولها النحاة.

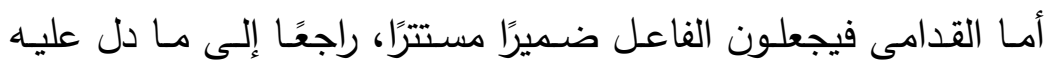
الكلام، والفاعل في الحديث ضميرًا عائدًا إلى ما دل عليه الفاعل، والفاعل في العبارة راجعًا لما دلت عليه الحال المشاهدة(؟). وفي ذلك يقول سيبويـه: اوإن شئت قلت: إذا كان غدا فأتني، وهي لغة بني تميم، والمعنى أنه لقي رجلا فقال لـه: إذا كان ما نحن عليه من السـلامة أو كان ما نحن عليه من البلاء في غدا فأتتي، ولكنهم أضمروا استخفافا، لكثرة كان في كلامهم، لأنه الأصل لما مضى وما سبقه وحذفواه(r). ويقول الفرراء: في قوله تعالى :

بلغت نفس الرجل عند الموت تراقيه؛(0). ويقـول ابن جنـي: اوإضمار الفاعل لدلالة الحال عليه كثير واسـع، منه ما حكاه سيبويـه من قولهم إذا كان غدًا فأتني، ...«("). وبنى فكرته على تعريف ابن جني للكلام بأنه كل: الفظ مستقل بنفسها وجنيت منه ثمرة معناهي"(v)، فهو عنده تعريف دقيق فقد ذكر فيه نماذج للجملة التي ليس لها سوى ركن واحد مثل: صسه ومهه ورويد ... فكل واحدة من هذه جملة مستقلة يجني المستمع منها ثرة معناها.

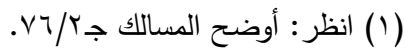

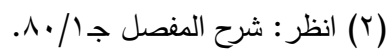

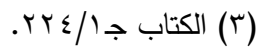

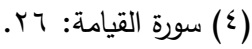

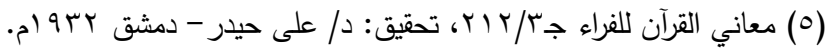

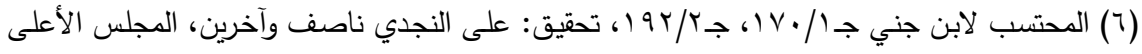




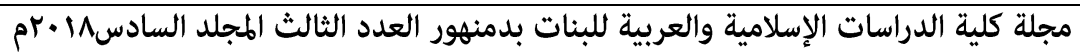
وكذلك الهاروسي: الذي رأى أن الاسم مع الحرف يكون كلامًا في

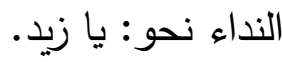

وابن طاحتّ: الذي رأى أن الكلمة الواحدة تكون كلامًا. وبعض النحاة: الذين يرون أن الحرف مع الفعل يكون كلاما في نحو: (ما قام) بناء على أن الضمير المستتر لا يعد كلمة.

مـع الأخذ في الاعتبار عنده بعدم إنكـار الإسـناد مطلقـا: فهـو قرينـة

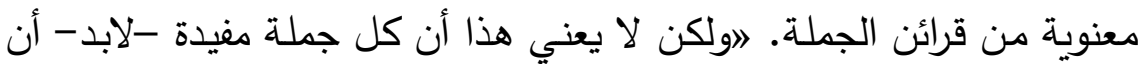
تكون مشتملة على الإسناده بل يلزم الاعتراف بوجود جملة ذات طرف واحد مؤدية لمعناها اعتمادًا على قرائن الأحوال، أو الموقف اللغوي الذي يكون فيه إلهون الأيه الكلام أو السياق، وهو كبرى القرائن. ومسن ثم انتقد النحساة في قولهم بالحذف والتقدير في القسم والتحذير وكذلك أسلوب النداء ('). فهن أسس التقسيه عنده: 1- التعريف المشـار إليه (لابن جني) إضـافة إلى تعريف (تشـارلز هوكت)، وهو أن الجملة هي الثكل النحوي الذي لا يكون تركيبا في شكل نحوي آخر، اي التركيب الذي لا يعد أحد المكونات في تركيب آخر . فقولك

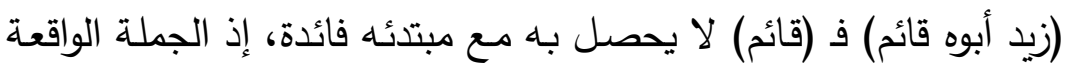
خبرًا، غير مقصود إسنادها بالذات. ومعنى ذلك أن الجملة المستخدمة للخبر أو للحال أو للنعت أو للصلة أو للمضـاف إليـه لا تسـى عنده جملـة مستقلة. بـل هـي: اهركب إسـاديهي للإخبار أو للحالية إلى آخره.

وكذلك كل من الخبر والحال والنعت يمكن أن يطلق عليه خبرًا مركبا أو حالًا مركبًا أو نعتًا مركبا. 


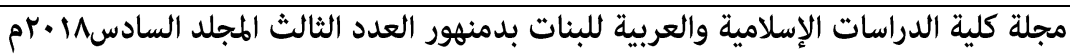

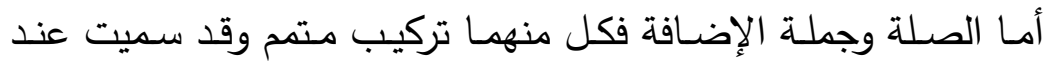
برجشتراسر مثل هذه التراكيب الجمل غير المستقلة، لأنها تقوم مقام جزء من جملة أخرى ('). r- لا يشترط الإسناد لكل جملة، بحيث يفرض على كل جملة مفيدة فلا تنعقد إلا إذا كان فيها الإسناد، ومعنى هذا أن هناك جملا إسنادية، يظهر فيها الإســناد واضـــًا لا يحتــاج إلـى إعمـال التقـدير ، وجمـلا غيـر إســادية لا حاجة إلى تكلف إضـمار حتى نقيمها على سواء الإسناد إذ إن تكلف الإسناد قد يخرجها عن الغرض الذي سيقت له.

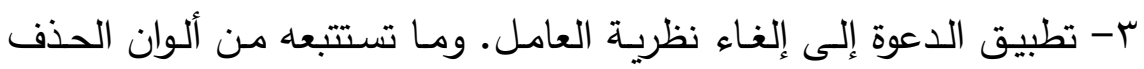
والتقدير • ومن ثم يطبق مبدأ تضافر القرائن النحوية في الجملة الذي دعا

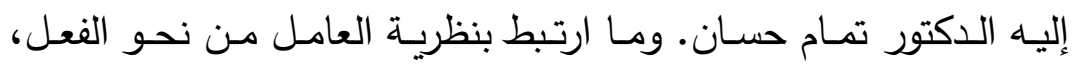
والفاعل، والمفعول بـه، والمفاعيل الأخرى، وكذلك الجـار والمجرور ، إذ

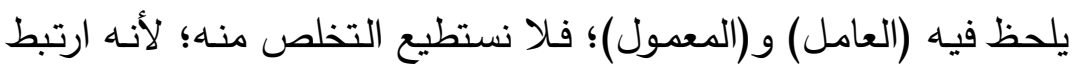
بالتراث وبفكرنا النحوي، والواجب أن نستعملها مفرغة من معنى التأثير والتأثز وليس معنى هذا أن يرفض كل ضـروب الحذف جملة بـل عنده الحذف على ضربين أحدهما تدعو إليه الصناعة النحوية ومحاولة الاطراد وتطبيق نظرية العامل وهذا ما يتنافاه والثاني يوميء إليه التركيب ويدعو إليه نظـام اللغــة ودواعي الاستعمال وتسـمح بـه الحسال المشـاهدة والقرائن الالة وهذا ما يقره(r). ع- إعادة النظر في تقسيم الكلم تبعًا لعدم الاطمئنان إلى ما اطلق عليه اسم أو فعل من قبل النحاة لاعتمـادهم على الشكل فقط في تصنيف الجمل فالمبدوءة باسم اسمية والمبدوءة بفعل فعلية. فلابد إذن من عود إلى تقسيم

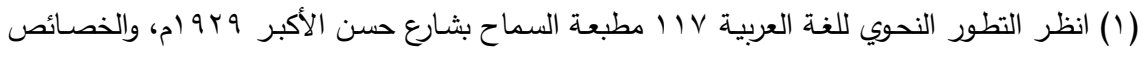

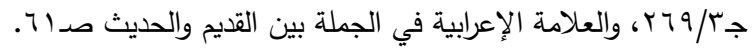

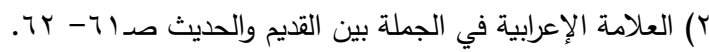




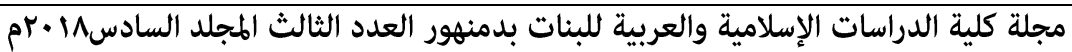
-من وجهة نظره- يقره الواقع اللغوي، فالنحاة مثلًَ يعدون جملة „كان الله غفورًا رحيماه جملة فعلية لأنها مبدوءة بفعل وهو 》كانه، وقد ثبت بما قرره الدكتور تمـام حسـان ورجحـه أن هذا المبني أي لكانه وجميع مـا

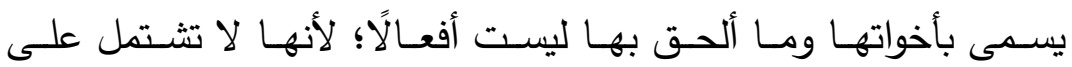
خصـائص الأفعـال بـل هـي أدوات دخلت على الجملـة الاسـمية لتحديد زمنها المبهم، وإذن ليست هذه جملة فعلية في تقسيمه- بـل هي جملة اسمية. لأن الجملـة لا تسـب في نوعها إلى الأداة الداخلة عليها، وإنمـا تنسـب إليها في معناهـا الجُمْلي فيقال: جملـة نفي أو جملـة استفهام أو أو جملة شرط. 0- لزم أن يكون لـلأداة إذا ضـامت الجملـة اعتبار في اسـاس التقسيم. لذلك سوف تتسب الجمل الإسـادية إلى صدروها،ـ ولذلك الموجزة، وأمـا غير الإسنادية فتسب إلى معناها التركيبي.

צ- الفرق بين النموذج والاستعمال كالفرق بين اللغة والكلام ('). فقد اعتمـد حماسـة في تقسـيم الجملـة على إعـادة تقسيم الكلمـة وإعـادة تصنيفها وقد اعتمد في التقسيم فيها على تقسيم الدكتور تمام حسان وبناء على الأسـس التي اعتمدها الأخيـر بنـاء على التقريق في الكـلام لذا قسم حماسـة الجملة إلى ثلاثة أقسام: القسيـر الأول: الجمهل التامـت: وهي (الجمل الإسنادية) التي يكون الإسـناد فيها مقصسودًا بالذات ويلزم فيها تضـام عنصـري الإسـاد، ولا يحذف أحدهما إلا إذا دلت عليه قرينة حالية أو مقاليه بحيث يكون المستمع في غير حاجة إليه، بل يصبح ذكره زائدًا عما يقتضيه الموقف اللغوي المعين، وهو ما يسميه القدامى الحذف الجائز؛ لأنه معلوم. 
الإسناد والجملة العربيةبين القدامى والهحدثين دراسة تحليلية مقارنة )

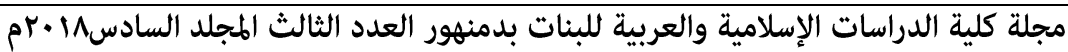
ويلاحظ أن التقسيم الأول للجملة وهي الجملـة التامـة الإسـنادية يندرج تحته تقسيم آخر إلى ثلاثة أقسام.

ا- الجملة الاسمية بة الجملة الفعلية س- الجملة الوصفية ونتناول هنا تمصيلا مقصده من الاسميت والفعليت:

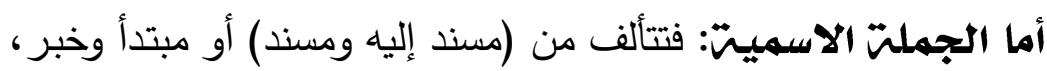

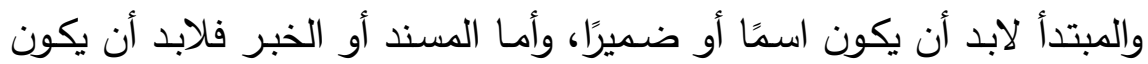
وصفا أو ما ينقل إليه من الاسم أو الجملة أو الجار والمجرور والظرف. مثل:

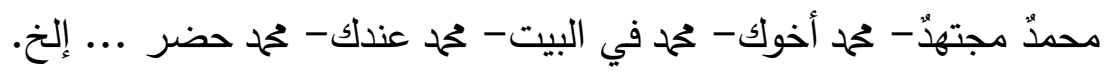
وعنده أن جملـة „كانه الناقصـة من الجمل الاسمية، وكـان أو إحدى أخواتهـا أداة داخلـة عليهـا لإفـادة معنى خـاص، ولا يعتد في تقسـيم الجملـة بالمعاني التي تضيفها الأدوات على الجملة. الرتبة في هذه الجملة رتبة حرة متى فهم الإسناد وهذه الرتبة الحرة قد تخضـع لمقيدات تجعلها رتبة ملزمـة. فقد تلزمها بوجوب تقديم المبتدأ وتأخير الخبر ، أو بوجوب تقديم الخبر وتأخير المبتدأ وهذه المقيدات في جوهرها رسائل سياقية لمنع اللبس في الجملة بحيث لا تختلط وظيفة كل من المبتدأ والخبر بغيرها - مبان

\section{تتبيه: إلى هنا يتفق مع النحاة في التركيب الاسمي.}

أمـا المبتــدأ الضــمير فيكـون ضـــير الموصــول أو ضــمير الإشــارة أو ضـمير الثـخص أمـا الخبر فإنـا ينطبق عليـه مـا ينطبق على الخبر في الجملة ذات المبتدأ الاسمي من حيث أنواعه والربط بينه وبين المبتدأ والتطابق 


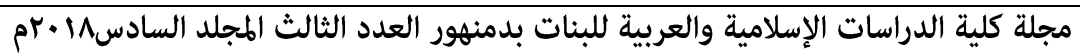

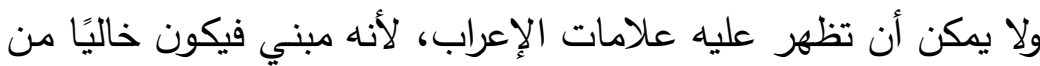

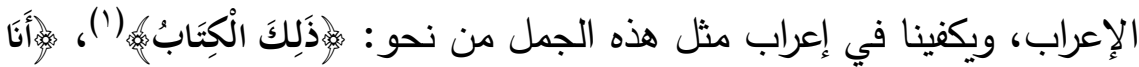

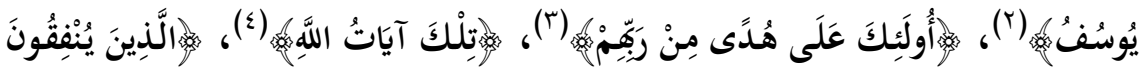

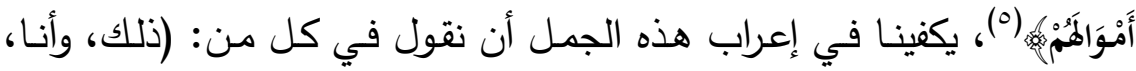
وأولئك، وتلك، والذين): ضمير إشـارة مبتدأ، وضمير شخص مبتدأ، وضمير موصول مبتدأ.

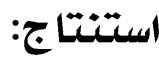

يلاحظ اتفاق الدكتور محمد حماسـة عبداللطيف مـع القدامى في مسمى التركيب الاسـي بـل وتكوينـه أيضًا إذ أنسه مـا يتكون مـن مسـند إليـه ومسند أو مبتدأ وخبر ثم أنه المبتدأ عنده يلزم أن يكون (اسما) إلا أنه يفترق معهم في أنـه قد يكون أيضًا ضـيرًا ويقصد بالضـير الاسم الموصـول أو اسم الإشـارة أو ضمير الشخص باعتبار أن الضمير قسم خاص من أقسام الكلمة. وهذا الفرق أجده لفظي فهـا الموصـول والإشـارة والضــير الثخصـي إلا أسماء في تقسيم الكلمة في القديم. مما أجده يتفق غالبا مـع النحاة في التركيب الاسمي. اللهم في مسمى المبتدأ إذا كان موصولًا أو إشارة بمسمى ضمير موصول مبتدأ، وضمير إشارة مبتدأ، واختصـاره الإعراب فـلا تقول مبني في محل رفع بـل يكتفى بالقول: ضمير إشارة مبتدأ، وضمير موصول مبتدأ وهكذا في غيره. 


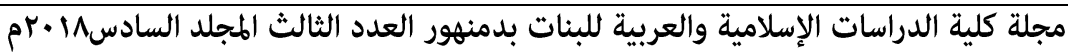

\section{وأما الجملت الفعليت:}

وتتألف الجملة الفعلية عنده من (فعل+ فاعل) أو (فعل + نائب فاعل) والفعل في هذه الجملة لابـد أن يكون فعـلً ماضـيًا، أو مضـارعًا غير مبدوء بالههزة أو النون أو التاء للمخاطب الواحد أو فعل أمر لغير المخاطب الواحد

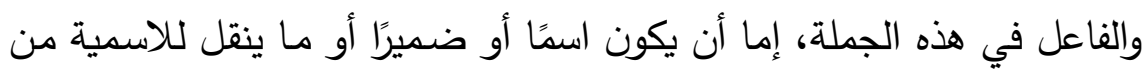
بقية أنواع الكلم، وكذلك نائب الفاعل.

مســتندًا فـي ذلــك: بـأن عبدالقاهر والزمخشـري يسـمونه فـاعلًا

$$
\text { اصطلاحًا (1) (1) }
$$

والرتبـة في هذا النوع من الجمل رتبـة ملزمـة، إذ يجب أن يتقدم الفعل

ويتأخر الفاعل.

فلا يرى التوسع في مثل (خحمد قام) على أنه جملة فعلية بل هو جملة

اسمية لأن حمله على الفعلية على مذهب الكوفيين يحدث اللبس بين الجملة الاسمية والجملة الفعلية.

واللغة بطبيعتها تتزع إلى عدم اللبس، والمطابقة ملتزمة بين جزئي هذه الجملة، في النوع (التذكير والتأنيث) في بعض الحالات، والثخص (الخطاب والغيبة) أما التعيين والعدد؛ فلا مجال لها فيها. والربط يتم عن طريق المطابقة المذكورة، والإسناد والتضـام، والعلامـة الإعرابية في الفاعل وهي الرفع، والفعل أشد تمسكا حتى إن النحاة ينظرون إليهما على أنهما شيء واحد(؟).

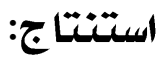

يلاحظ اتفاق حماسة مع النحاة في التراث النحوي على مسمى التركيب الفعلي للجملة. 


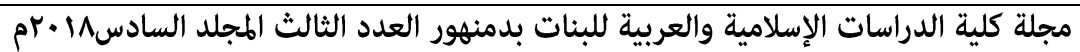

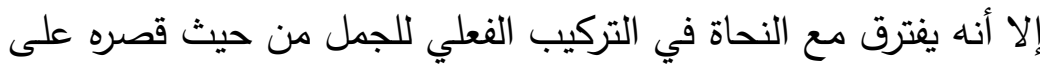
أنواع أو صـور محددة مـن التركيب الفعلي الثـامل في التراث النحوي حيث قصر الجمل الفعلية على ما كان الفعل فيها محدد الأوصساف بأن يكون واحدًا من هذه الصورة الآتية لا غيرها:

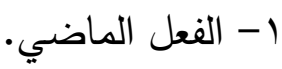
r- الفعل المضـارع الغير مبدوء بالههزة أو النون أو التاء للمخاطب الواحد.

$$
\text { فينحصر في (يضرب)، أو (تضربان) أو (تضربون). }
$$

ب- أو فعل أمر لغير المخاطب الواحد فينحصر في (اضربا) أو (اضربوا).

\section{أما من جهن المثاعل:}

فنراه يتفق مع النحاة في كونه اسما أو ضميرًا، أو ما ينقل للاسمية من بقية أنواع الكلم. وكذلك نائب الفاعل.

ثم نـراه يتفق مـرة أخرى مـن حيث الرتبـة مـع مـهب البصـرين الذين لا يجيزون تقديم الفاعل على الفعل ومن هنا كانت الرتبة في الجملة الفعلية ملتزمة فلا يرى التوسع الذي ذهب إليه الكوفيون لأنه عنده يحدث اللبس بين التركيب الاسمي والتركيب الفعلي للجملة. ويتفق أيضًّـا معهم في المطابقـة بـين جزأي الجملـة الفعليـة في النـوع

$$
\text { (التذكير والتأنيث). والشخصي (الخطاب والغيبة). }
$$

وإن كان قد حدده بقوله (في بعض الحالات) ولم يبرزها حتى نعلم وجه الاختلاف مع النحاة القدامى.

كما أنه يتفق مـع النحاة في عدم المطابقة في التعيين والعدد حيث أن مذهب الجمهور من النحاة على توحيد الفعل فلا يثنى أو يجمع عند إسناده للاسم الظاهر المثنى أو الجمع، على الرغم من اعترافه بأن المطابقة في العدد بين الفعل والفاعل تعد لهجـة لبعض العرب، والنحاة يتأولون ذلك بمـا ينفي وجوده على حد قوله. 


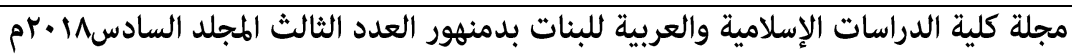

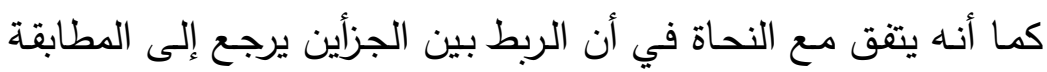
المذكورة من حيث التذكير والتأنيث والإسناد والتضـام والعلامـة الإعرابية هي

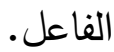

\section{القسيه الثاذي: الإسناديت الموجزة(1):}

ويعنى بها الجمل التي لا تتألف إلا من طرف واحد، وهي في عرف

نحــاة التـراث مـا حـذف منهــا فـي إطـار الحـذف الواجـب، أو الاســتار ، أو الإضمار الواجب.

فتعد عند حماسـة مـن قبيـل الجملـة المـوجزة، فـاذا كـان الطـرف الثاني لا يظهر مطلقًا فلا اعتداد به، ولا داعي لتكلف حسبانه جزءًا من أجزاء الكلام المنطوق. ويكتفى بالطرف المذكور فقط لأن الإيمان بالثكل اللغوي يغني عن كثير من التعصف والتكلف. وتتتوع الإسناديت الموجزة إلى ثلاثن أنواع هي: 1- الجملة الفعلية الموجزة. ب- الجملة الاسمية الموجزة.

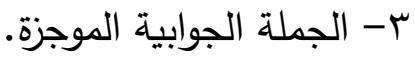

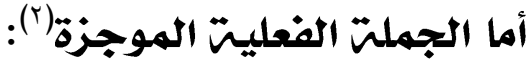

فهي كل فعل استتر فاعله وجوبا عند النحاة ويمثل ذلك حالتي: التكلم

مطلقا، والخطاب للمفرد المذكر .

$$
\text { وتتمثل في: وفي }
$$

1- الفعل المضارع المبدوء بالهمزة، مثل: (أتكلم)، (أوافق)، وعند إعرابه نقول: فعل مضارع للتكلم. 


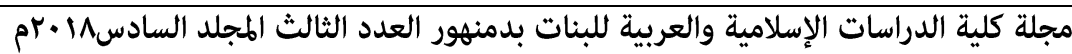
ץ- الفعل المضارع المبدوء بالنون مثل: (نتكلم)، (نوافق)، وعند إعرابه نقول: فعل مضارع للمتكلمين. r- الفعل المضارع المبدوء بالتاء للمخاطب مثل: (تتكلم)، (توافق) وعند إعرابه تقول فعل مضنارع للمخاطب. ع- فعل الأمـر للمخاطب الواحد مثل (استقم) وعند إعرابـه تقول: فعل أمر للمخاطب.

\section{وأما الجملتش الاسميته الموجزة) (1):}

فهي كل اسم أفاد معنى مستقلا يحسن السكوت عليه عند ذكره. ومن

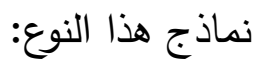

ا- الاسـم المرفوع بعد لـلا الامتناعيـة بشرط أن تفيد مـع هذا الاسـم معنى

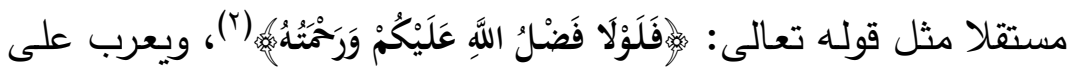

$$
\text { أنه اسم مرفوع. - (أن }
$$

ب- الاسـم المرفوع المعطوف عليـه اسـم آخـر بـواو المعيـة نحـو: (كل رجل

$$
\text { وضيعته). }
$$

ب- المصدر المضـاف الواقع بعده حال لا يصلح للإخبار ، وكذلك مـا يكون

$$
\text { هذا المصدر مضافا إليه نحو: (ضربي زيذًا قائما). }
$$

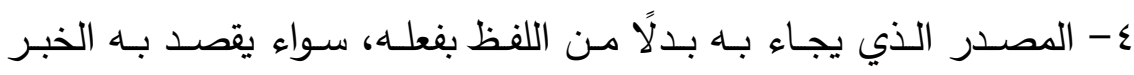

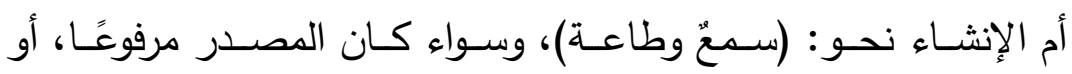
منصـوبا، ويكفي أن نقول في إعراب هذا المصدرر - مصـدر مرفوع أو

$$
\text { مصدر منصوب. }
$$




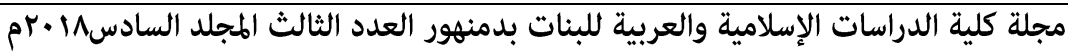

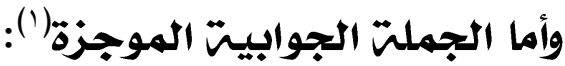

فهي ما كانت جوابا عن سؤال وكان مكتفيا بنفسه، وهي التي يذكر فيها عنصر واحد من عناصر التركيب، إذا ذكر وحده في غير سياق الإجابة عن سؤال لا يكون مفهما يحسن السكوت عليه. ولكنه في سياق الإجابة عن سؤال

مفهم ومفيد (r).

وهنـا يتفق الدكتور حماسـة مـع رأي ابن طلحة في رؤيتهـه بأن الكلمـة

الواحدة قد تكون كلامًا إذا قامت مقام الكلام، (كنعم) و(لا) في الجواب(r).

حيث أن كلًا منهما لا تقال معزولة عن سياق معين يكثف المراد منها.

كما يتفق حماسـة مـع نحساة التراث في الحكم على الجملـة الإسـنادية الجوابية الموجزة من حيث أنها جملة إسنادية من جهة ومن جهة أخرى أنها جملة ذات طرف واحد. إلا أنها على التقدير في التراث النحوي وهي بدون تقدير في رأي حماسة ورأي ابن طلحة اكتفاءً بالسياق الذي يحفظ لها المعنى المفيد عند الجميع.

والحقيقة: أن حماسة لم يأتي بجديد في إطار الجملة الإسنادية الموجزة لاتفاقه مع القدامى في الحكم عليها في كونها جملة إسنادية أما الخلاف فهو على تقدير العنصر الثاني أو عدم تقديره وهو مفهم من السياق عند الجميع. لذلك نحاة التراث يستطيعون تقديره، فيعترفون به عنصرًا إسناديا ثانيًا محذوفًا. أمـا حماسـة: فيعترف بـه غير مقدر وغير محذوف مكتف بفهمـه مـن

وأرى أنها مكابرة؛ لأن مثل هذه الجمل من قبيل -الجمل الإسنادية فيبقى السؤال حينئذ: هذا طرف إسنادي واحد فأين الآخر إذ لم تعترف أنه محذوفه؟ ثم إذا لم تعترف بأنـه طرف إسـادي ثانٍ فكيف يتحقق فيها القول بالتركيب

$$
\begin{aligned}
& \text { (1) العلامة الإعرابية في الجملة بين القديم والحديث صده } 9 .
\end{aligned}
$$

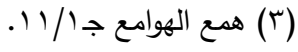




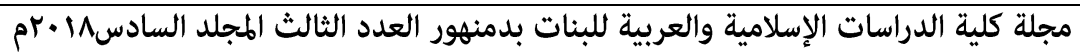
الإسنادي، ومعلوم أن التركيب الإسنادي لله مكونات ثلاثة: مسند ومسند إليه

لذا رأيت أن لكي يحافظ على الاتجاه الذي طالمـا اختاره لنفسه- ليس هو فحسب بل شأن كل نحاة الحديث في القول بعدم التقدير معتمدًا على فهمـا من السياق هو الذي دفعه للقول بأن هذه الأساليب ذات تركيب إسنادي مبني على طرف إسنادي واحد ولذلك سميت عنده بـ: الإسنادية الموجزة.

القسيه الثالث: الجمهل غير الإسناديته('): وهي الجمل التي يمكن أن تعد جمـلً إفصاحيه أي أنها كانت في أول أمرهـا تعبيـرًا انفعاليا يعبـر عن التعجب أو المدح أو الذم أو غيـر ذلك من المعاني التي أخذ التعبير عنها صورة محفوظة ثم جمد بعض عناصـرها على صـيغته التي ورد بها فجرى مجرى الأمثال ويدخل ضـمن هذه الجمل -عند حماسة- الخوالف استنادًا لقول الدكتور تمام حسان: "الخوالف كلمات تستعمل في أسـاليب إفصـاحيه، أي في الأسـاليب التي تستعمل للكثف عن موقف انفعالي ما والإفصاح عنه، فهي من حيث استعمالها قريبة الثبهة بما يسمونه

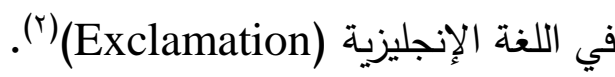
وهذه الخوالف اربعة أنواع: ا- خالفة اسم الفعل وسميها الدكتور تمام حسان (خالفة الإخالة) أمـا حماسـة فضل تسميتها باسم الفعل لعدم وجود سند لتسمية الدكتور تمام حسان اما تسمية اسم الفعل فسندها تسمية ابن صـابر ليصبح تجرده من المقيدات مميزا عن غيره من "الخوالف".

$$
\begin{aligned}
& \text { r- خالفه (التعجب). } \\
& \text { r- خالفه (المدح والزم). }
\end{aligned}
$$




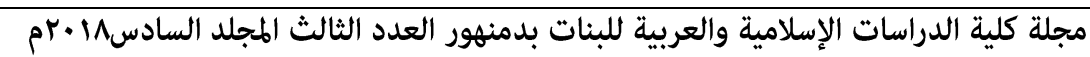
؟- خالفه (الصوت) أي أسماء الأصوات عند النحاة. والخوالف الأربعة اصطلاح الدكتور تمام حسان اما د/حماسه ففضل أن يبقيها على مصطلحاتها الأساسية وهى عنده على النحو التالي: 1- جملة (الخالفة) ويقصد بها اسم الفعل مع ضميمه. r- الجملة التعجبية. - جملة المدح والذم. ع- جملة خالفه الصوت. 0- الجملة الندائية. 1- الجملة القسمية.

V-الجملة التحذيرية والاغرائية. V (1) النتيـجن:

أولًا: اختلاف المحدثين مـع القدامى في تسمية بعض التراكيب بالجملة الندائية فبعضهم يطلق عليها مسمى مركب لفظي ولا يرتفع إلى منزلة الجملة ولا يصح تسميته بالجملة أيضًا على نحو ما يراه الدكتور مهدي المخزومي في

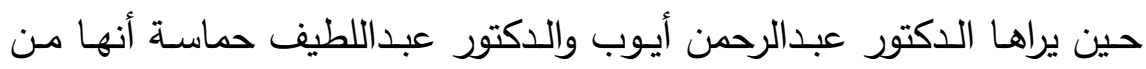
الجمل غير الإسنادية.

إضـافة إلى تأثرهم بنظريـة إلغاء العامل النحوي ومـا أحدثته من جلب للأفكار فهذا وإن كان مفيدًا من جهة رواج الفكر ونمائه والكثف عن كثير من مدخلات وأسرار اللغة العربية إلا أنه يحتفظ للسـابقين بمنهجهم القويم والسديد من وجهة نظري لأنه الأخصر والأضسبط. ولأنها منهج حُفظ وحُفر في دراسـة التراث النحوي لا مناص عنه.

ثانيـا: يرجع عدم الاتفاق بين المحدثين وبعضهم البعض إلى أن كل باحث نحوي أو لغوي أو حتى دارس من المحدثين بنى تقسيمه للجملة بنـاء على اختياره لتعريف محدد للجملة. 


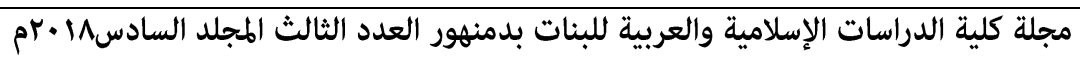

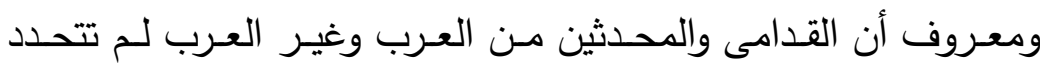
عندهم الجملة بتعريفها تعريفًا مستقلًا يساعد على فهم وحدات التركيب اللغوي ولي ولي في إطـاره الصـحيح. وطالمـا اختلفت التعريفـات لتحديـد مفهوم الجملـة اتبعـهـ اختلاف في التقسيم حتى وصلنا إلى أن كل منهم يكون لله منظور خاص في التقسيم يحاول معه الوصول إلى تصنيف جديد. ويعكس هذا التقسيم أفكار راسخة لديهم وهي الفرار من فكرة التأويـل والتقدير وكذلك الفرار من فكرة العامل النحوي. وما يتبعه من تغيرات حتى رأينا أننـا وصـلنا إلى مرحلـة (تمثل الفوضـى) في تقسيم الجملة ومسن ثم يصسعب إعطاء صورة محددة للتقسيم وبخاصة عند المحدثين. ثالثًَا: يعترف بفضل الدراسات الحديثة لتحليل اللغة القديمة وما وصلنا إليه في الواقع الحديث وهذا يعد ثراء في حد ذاته علمي وفكري ولغوي. كما يعترف لها بمحاولة الربط بين اللغة القديمة وما استحدث من ظهور مصطلحات وتركيبات يجب تحليلها وتفكيكها لمعرفة أصسولها، لاتخاذ الحذر

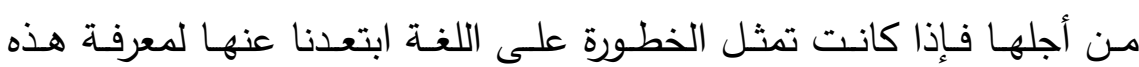
الأصول المنبعثة منها والتي تمثل هدفا خطيرًا على اللغة. وإذا كانت تمثل تواصل ذاتي من منابع اللغة وثقنا الصلة بها إعزازًا لهذه الأصول ومن ثم يلزم الاعتراف بالمقترحات الهادفة من وجها نظري، وترك مـا 
الإسناد والجملة العربيةبين القدامى والمددثين دراسة تحليلية مقارنة )

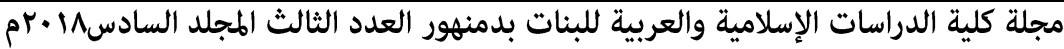

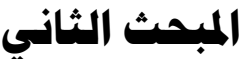

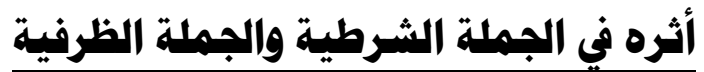

كما اتبع النحاة منهج سيبويها في تصوير الجملة العربية فيلزم تكوينها من ثلاث عناصر هي كما ذكر : المسند إليه، والمسند، والإسناد؛ كذلك اتبعـه الجمهور في تقسيم الجملـة قسمين اثثين فقط، القسم الأول: الجملـة الفعليـة والقسم الثاني: الجملة الاسمية، وقد ورد الإجماع بذلك.

\section{أما الزمخشثري فقل خرج عن الإجماع}

ورأى أن الجملة على أربعة أضرب: فعلية واسمية وشرطية وظرفية وأتى

بالأمثلة لكل منها فقال:

اوالجملة على أربعة أضرب: فعلية واسمية وشرطية وظرفية، وذلك: زيلّ

ذهب أخوه، وعمروٌ أبوه منطلق، وبكرٌ إن تعطه يشكرك، وخالدٌ في الدار «(1).

فقد مثل للجملة الشرطية بخبر المبتدأ (فإن تعطده يشكرك) خبر عن ون

(بكر) وأما الجملة الظرفية فقد مثل بقوله: (خالد في الدار) . وهو يريد أن في الدار جملة، وهي المقصـود بالظرفيـة، لأن الفعل استقر حذف قبلها، فانتقل الضمير من الفعل إليها، وأضدر فيها.

وعقب ابن يعيش على الزمخشـري منتقدًا هـذا التقسيه الذي

أدلى بـه، وقـال: إنـا تقسـيم أبي على الفارسـي وهي قسمة لفظيـة أي شكلية مردودها أن الجملة ضـربان (فعلية واسمية)، لأن (الجملة الثرطية) عنده في الحقيقة مركبة من جملتين فعليتين (الثـرط) (فعل وفاعل) و (الجزاء) (فعل،

وفاعل)، والظرف في الحقيقة (للخبر الذي هو استقر) وهو (فعل وفاعل)(r). ووافق بعض الهحدثين وهو الد كتور مهدي الهخزومـي (r) ابن يعيش في وجهن نظره، بأن هذا التقسيم شكلي لفظي مردود في تحقيقه إلى

$$
\begin{aligned}
& \text { (1) المفصل في شرح المفصل جـ/N1/ (Y) }
\end{aligned}
$$

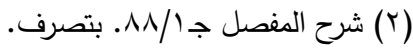

$$
\begin{aligned}
& \text { (ץ) في النحو العربي نقد وتوجيه صدو المفه }
\end{aligned}
$$




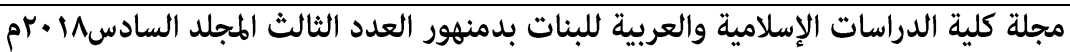
أحد القسمين المعلومين في الجملة منذ القديم وهي أن الجملة تتقسم إلى اثتين لا ثالث لهما جملة اسمية وجملة فعلية.

كما وافق الدكتور / محم حماسة عبداللطيف من المحدثين ابن يعيش في انتقاد جملة الثرط، الأن الأصـل في الجملـة الفعلية أن يستقل الفعل بفاعلهـ نحو: قام زيد إلا أنه لما دخل ههنا حرف الثرط ربط كل جملة من الثرط

$$
\text { والجزاء بالأخرى (1) }
$$

اوالثـرط معنى مـن المعـاني التي تدخل على الجملة كالنفي والتأكيد والاستفهام، وإذا وجد ما يسمى بالجملة الثرطية قسيمًا للاسمية والفعلية كان معنى ذلك أن توجد جملـة تأكيديـة ونفييـه واسـتفهامية في شركة مـع الفعليـة والاسمية، وهذا ما لم يقل أحد بها(ب). أمـا الزركثي فقد وافق الزمخشري، حيث يعد (الجملة الشرطية) جملة

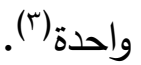

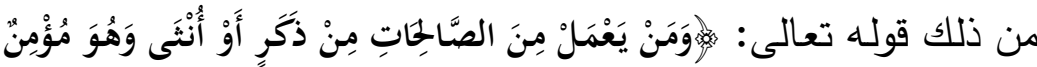

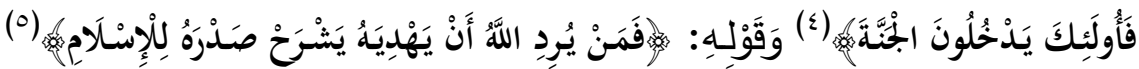

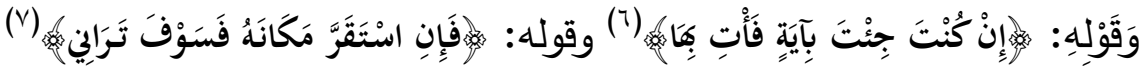

$$
\begin{aligned}
& \text { (1) العلامة الإعرابية في الجملة بين القديم والحديث صده ب. }
\end{aligned}
$$

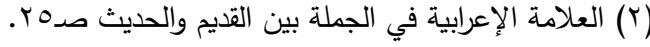

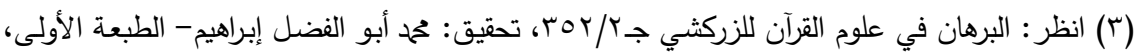

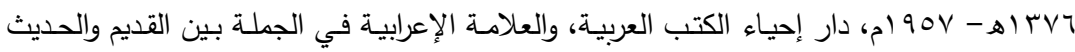




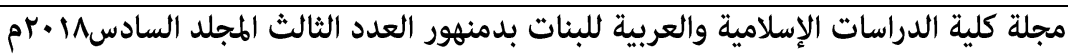

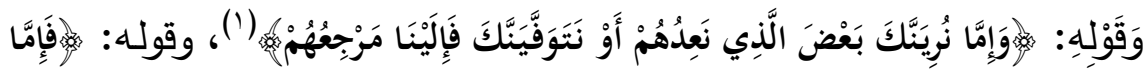

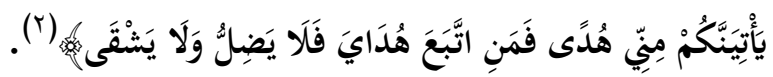

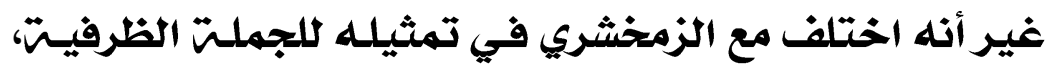
فعنده: الجملة الظرفية هي المصدرة بظرف أو جار ومجرور قبل اسم مرفوع

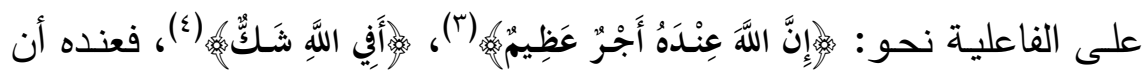
(أجر) فاعل للظرف، و(شك) فاعل للجار والمجرور وكذلك نحو قوله تعالى:

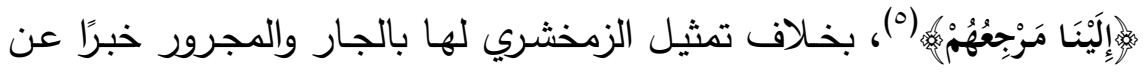

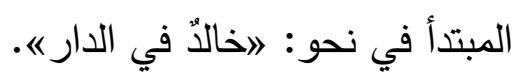

كما وافق الدكتور فخر الدين قباوة من المحدثين الزمخشري في مجيئه بالجملة الشرطية حيث كانت التقسيمات عنده ثلاثة: فأقسام الجمل عنده ثلاثة: ا- الجملة الاسمية، ب- الجملة الفعلية، ب- الجملة الشرطية. وهي عنده التي

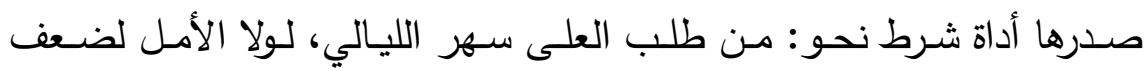
العمل، إذا أكرمت الكريم ملكته.

\section{واحتج في ذلك:}

بأن الخليل والمبرد إشارا إلى الجملة الشرطية، ثم جاء الزمخشري ونص عليها، ومثل لها بخبر المبتدأ في قولك: بكر إن تعطه يشكرك ورأى أن هذا هو الصواب. معتلًا بأن:

الجملـة إمـا أن تقوم على تركيب إسـادي، كالفعل والفاعل، أو المبتدأ

والخبر ، وإما أن تقوم على تركيب شرطي فكما أن المبتدأ لا يستقل إلا بذكر الخبـر، كذلك الثـرط لا يسـتقل إلا بــكر الجـزاء، والصـيرورة الثـرط والجـزاء 


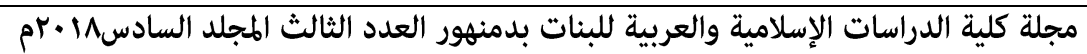

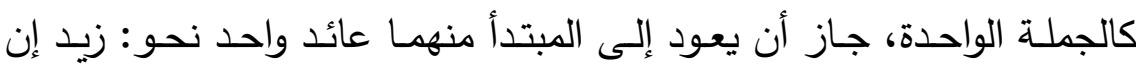
تكرمه يشكرك عمرو. فالهاء في تكرمه عائدة إلى زيد ولم يعد من الجزاء ذكر ولو عاد الضمير منهما جاز وليس بلازم (1). والاحتيـار: أن الاسم المرفوع مبتدأ مؤخر ، حذف خبره، لدلالـة شبه الجملة عليه. فالجملة اسمية(r).

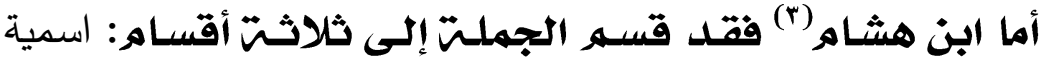

وفعليـة وظرفيـة، ولـم يوافـق على الزيـادة التي اضــافها الزمخشـري بالجملـة الثرطية اعتقادًا منه بأنها من قبيل الفعلية ثم عرف كل من هذه الأقسام. فالأسمية هي: التي صدرها اسـ، كـ (زيد قائم، وهيهات العقيق، وقائم الزيدان) عند من جوزه، وهو الأخفش والكوفيون. والفعلية هي: التي صدرها فعل، ك (قام زيد، وضُرب اللصُّ، وكان زيد قائما، وظننته قائمًا، ويقوم زيدٌ، وقُمْم).

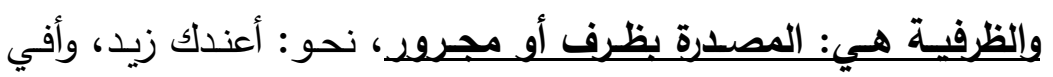
الـدار زيـد، إذا قدرت زيـدًا فـاعلًا، بـالظرف والجـار والمجرور ، لا بالاسـقرار المحذوف، ولا مبتدأ مخبرًا عنه بهما. أما السيوطي فأتبع ابن هشـامر التقسيـيه . فعنده تنقسم الجملة إلى

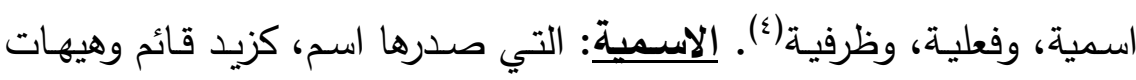
• العقيق

والفعلية: التي صدرها فعل، كقام زيد، وضُربِ اللص، وكان زيد قائما، وظننته قائمًا. ويقوم وقم.

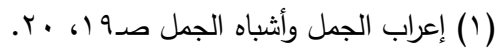

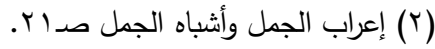

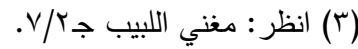

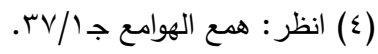




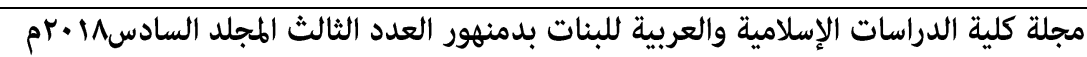
والظرفية: المصدرة بظرف أو مجرور، نحو عندك زيد، أو في الدار زيد إذا قدرت زيدًا فاعلًا بالظرف أو المجرور ، لا بالاستقرار المحذوف، ولا مبتدأ مخبر عنه بهما.

وكذلك أيضًــا انتقـد الزمخشـري زيادتـهـ للشـرطية تقسـيمًا رابعًا للجملـة

والصواب عنده: أنها من قبيل الفعلية، لأن المراد بالصدر المسند، أو المسند إليه، ولا عبرة بما تقدم عليها من الحروف.

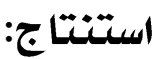

ا- مكونات الجملة الشرطية عند الزمخشري ثلاث عناصر ، حددها بناء على التركيب الذي مثل به في قوله: بكر إن تعطه يشكرك. فبكر مبتدأ مخبر

عنه بالجملة الشرطية. (إن تعطه يشكرك) ومكونات التركيب إذًا ثلاثة. وهي: أ- الأداة الرابطة (إن) ب- فعل الثرط تعطه. ج- جواب الثرط (يثكرك).

r- مكونـات الجملـة الظرفيـة عند الزمخشـري: هـي جملـة مكونـة مـن جـار ومجرور مخبر بها عن مبتدأ.

أخذ ذلك من خلال التركيب الذي مثل به في قوله (خالد في الدار). فجعل في الدار جملة ظرفية من حيث كانت متعلقة بالفعل المقدر فلما حُذف انتقل الضمير من الفعل إليها.

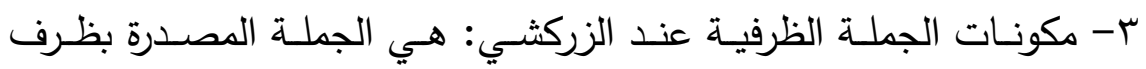

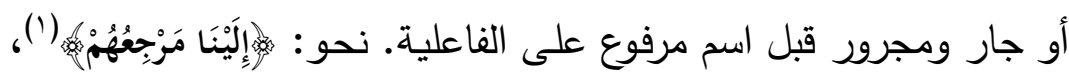

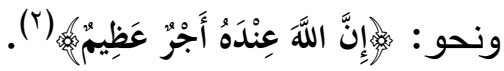




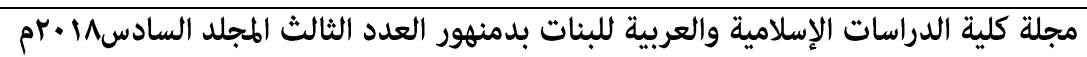

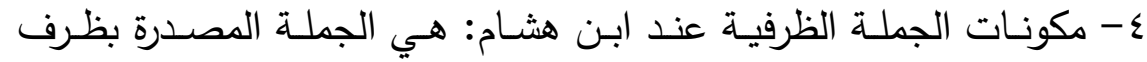

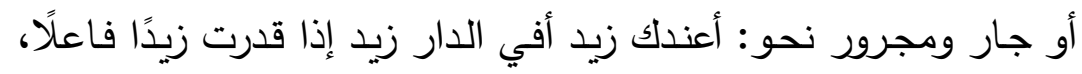

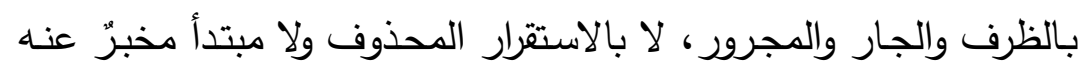
بهما

ه- تتعين الجملـة اسـمية وفعليـة في التراث النحـوي، مـن خـلال عناصـرها الموجودة وعن طريق الحذف والاستتار يكمل للجملة ما أرادوا من قوالب.

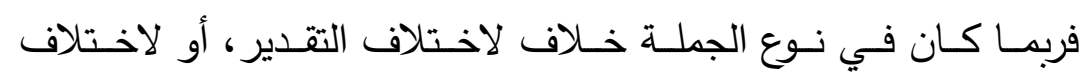
النحوينين.

ج- اشـتراك مصـطلح الجملـة الظرفيـة بـين المتقدمين والمتأخرين في التراث النحوي إلا أنـه على الرغم مـن ذلك فـان بينهمـا بونـا شاسـا في تحديد مفهوم مصطلح الجملة الظرفية عند كل منهما. فالزمخشري يحدد الجملة الظرفية من خلال مقابلة نماذجها اللغوية ببقية

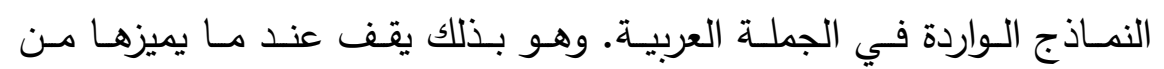
خصائص لغويتة.

أمسا ابن هشام فإنـه لم يعن برصد هذه الخصائص بقدر ما التقت إلى لحظ الاعتبارات الذهنية ورعاية الأسس المذهبية، فنحو: (أعندك زيد؟) يمكن أن يكون من قبيل الجملة الظرفية، ويمكن أن يكون من قبيـل الفعليـة، كمـا

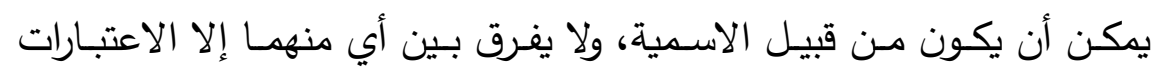
المذهبية التي تتحكم في التوجيه النحوي. - فإذا اعتبرت (زيدا) فيها (فاعلا) للظرف نفسه كانت ظرفية. - وإذا اعتبرته (فاعلا) لمتعلق الظرف كانت فعلية. - وإذا اعتبرت الظرف (خبرا) لما بعده كانت اسمية.. فالنموذج اللغوي واحد، وخصائصسه اللغويسة واحدة، بل التوجيه النحوي واحد أيضًا، والخلاف كله يرتد إلى (اعتبارات) التوجيه فحسب. 


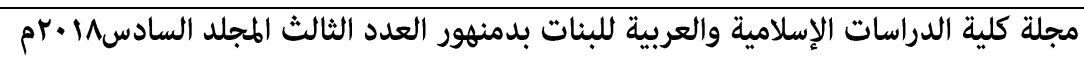
تتبع النحاة المحدثون القدامى في كيفية نشأة الجملة الثرطية حتى قبل أن تصل إلى مرحلة التسمية بلفظ الجملة الشرطية، فإذا كان الزمخشري يرجح إليه فضل السبق في ابتكار مصطلح الجملة الشرطية كيانا مستقلا من كيانات الجملة العربية إلا أنه قد سبق بأئمـة النحاة الذين عرضوا لهذا الكيان من لدن الن النهان سيبويـه إلى المبرد إلى ابن السراج إلى السيرافي إلى الفارسي. وهذا إنما يدل على أن النحاة قد أدركوا منذ القديم وجود خصائص مميزة إنى إنى إنى لهذه الجملة في مبناها، ومعناها، ووظيفتها إلا أنهم ظلوا لا يعترفون بها كيانا مستقلً وإنما ظلاوا يصـيغونها في إطلار غيرها حيث استقر عندهم وضعهابصورة عامة في نطاق الجملة الفعلية، أو تحليلها إلى عنصريها، ووضـع كل منهما أيضًا في ما يناسبه من الجمل الفعلية أو الاسمية(').

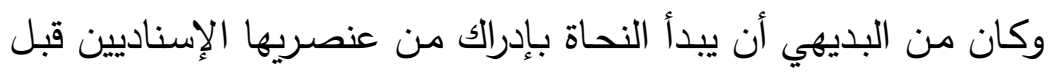
تقرير العلاقات الممتدة بينهما. وذلك أن كل من عنصريها اتسم بالبساطة في هذه المرحلة وهكذا يكون تصنيف الثرط وحده في الجملة الفعلية والجواب وحده في الفعلية أو الأسمية خطوة مسبقة ضرورية قبل البدء في إدراك التركيب المركب وتصنيف الجملة الشرطية على الوجه الثامل. وقد أنصف النحو الحديث النحاة(r) الذين ادركوا هذه الفترة وهي الفترة التي سبقت الزمخشري بهذه الدراسـات المسبقة والبسيطة والتي كانت العدوم الأساسي لبناء واستكمال الفكرة عند الزمخشري قبل ظهور المصطلح. وكان المتوقع لديهم في الفترة التالية للزمخشري الانتقال في دراسة هذه الكيانات من مرحلة إدراك العلاقات البسيطة بين المفردات إلى مرحلة الوعي العلمي بمقومات المركبات. 


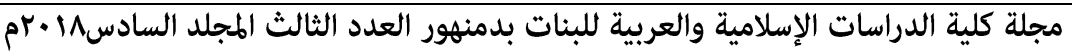
اولكن البحث النحوي- من وجهة نظرهم- على العكس من ذلك ارتد مـرة أخرى، فأغفل المقدمات الموضـوعية التي حدت بالزمخشري إلى تقرير

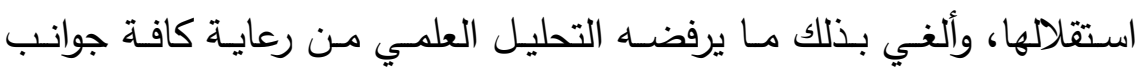
الظـاهرة المدروسـة- وهي: هذه الجملـة الثـرطية- سـواء في مجال تكوينها، أو في تحديد علاقاتها أو في تقرير وظائفها- وبذلك عاد مرة أخرى إلى تبسيط مـا هو مركب، وتجاهل مـا هو ثابـت والارتداد إلى اجترار مـا فـات، ورفض النتائج والاقتصار على المقدماته ('). وترجع الأسباب في ذلك من وجهة نظر الدكتور على أبو المكارم إلى عدد من الأسباب يشير إلى بعض منها: 1- حجاب المعاصـرة الذي ورثه معاصـروا الزمخشري فقد كان أكثر شـاعة منهم في التقدم في التراث النحوي خطوة أبعد مما خطا إليه معاصروه. وكان لسـان هؤلاء المعاصسرين لـه ابـن السيد البطليوسي ابـهـ، ابن

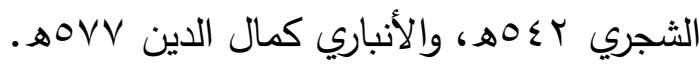
r- غلبة روح العصر في العكوف على ما قدمه الأسلاف من أفكار .

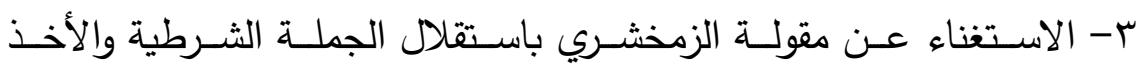
بالمأثورات النحوية التقليدية دون أن يفقد التحليل النحوي للعناصر المكونة

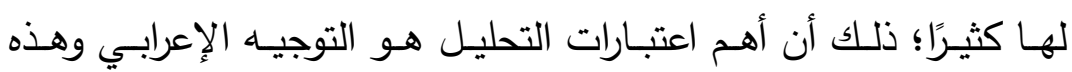
المأثورات قادرة على تفسير مكونات هذه الجملة دون الحاجة إلى تضـارب

$$
\text { يدفع النحاة إلى الخروج عليها. }
$$

والـذي يؤيـد ذلـك أن الـذي رفض قـول الزمخشـري باسـتقلال الجملـة الثرطية عند النحاة المتأخرين لم يصحبها إلغاء ما استقر في التحليل النحوي لها من خصائص. 


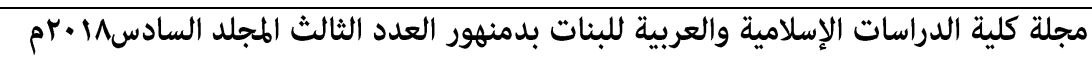

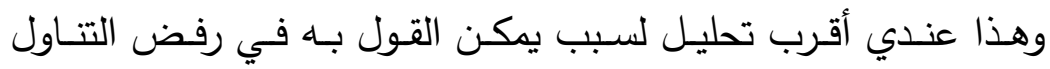
لمصطلح الجملة عند معاصري الزمخشري بعدما ذاعه الزمخثري. فإذا كان القدامى قد تركوا النماذج الموروثة هي التي تعبر عن نفسها إلا أن النحو الحديث تتاولها بالتحليل لأهم الضـوابط والأحكام التي احتوت هـي عليها تلك النماذج لتشمل الموضوعات: ثلاث عناصر : 1- مكونات الجملة الشرطية. r- العلاقات السياقية لها. r- الخصائص المميزة لها. مكونات الجملة الشرطيتّ:

أول عنصر من العناصر التي تتكون منها الجملة الشرطية: أدوات الثرط. إذ هي الرابط الذي يربط بين حدثين مختلفين بحيث يكون أحدهما مقدمـة والأخر نتيجـة وهذان الحدثان اللذان يتتم ربطهما ليسـا قائمين بذاتهما وحدهما، بـل إنهما مسندان بالضـرورة إلى من يقوم بهما وبهذا يكون التـرابط لـيس بـين حـثين بـل بـين تـركيبين إسـاديين لكـل منهمـا مقوماتـه الإسنادية، من محكوم ومحكوم عليه. والذي يقوم بالربط هي الأدوات إذ هي التي تقوم بترتيب العلاقة بين

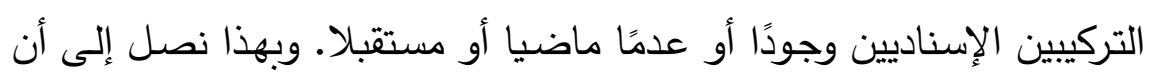
مكونات الجملة الثرطية في الحقيقة ثلاث مكونات هي: الأداة وتركيب فعل الشرط وتركيب جواب الشرط('). 
الإسناد والجملة العربيةبين القدامى والهحدثين دراسة تحليلية مقارنة )

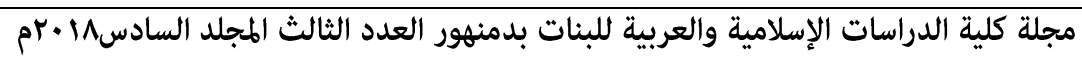

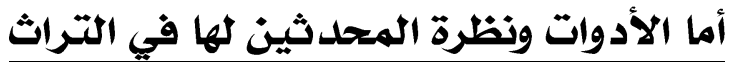

أخذ الباحثون على النحو في التراث بالنسبة للأداة أن النحاة لم يدرسوا

الجملـة الشـرطية إلا مـن خـلال الشكل الإعرابـي فيهـا. إذ رعايـة الخصـائص

الإعرابية للأفعال الواقعة بعد أدوات الشرط كانت الأساس في هذه الدراسة(').

وكان التقسييه لألدوات قسمين:

التقسيه الأول بحسب التصنيف النحوي إلى ثلاثن أقساهي:

وقد انقسمت بهذه الاعتبارات إلى أقسام ثلاثة:

ا - حرف باتفاق: وهو إنْ.

r- اسم باتفاق وهو دن، وما، ومتى، وأي، وأين، وأيان، وأنى، حيثما. r- مختلف فيه بين الاسمية والحرفية، وهو: (إذما) و (إذا ما) و(مهما). التقسيه الثثاني بحسب ما تمثيده من محنى:

وقسمت أيضًا بهذا الاعتبار إلى ستة أقسام (r):

1 - للدلالة على من يعقل ثم ضمن معنى الشرط وهو (من).

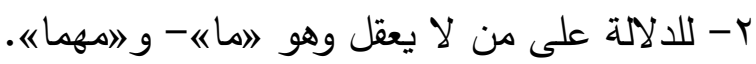

ب- للدلالة على الزمان ثم ضمن معنى الشرط متى، وأيان.

ع - للدلالة على المكان ثم ضمن معنى الثرط وهو أين، وأنى وحيثما.

ه- ما يستخدم للدلالة على مجرد التعليق وهو إن وإذما.

צ- ما هو متردد بين أنواع الاسم الأربعة وهو (أي).

أما أدوات الشرط غير الجازمت فهي:

ا - لو: وتفيد تعليق الجواب على الثرط في المستقبل، كما تفيد تعليق الجواب

على الشرط في الزمان الماضي (r).

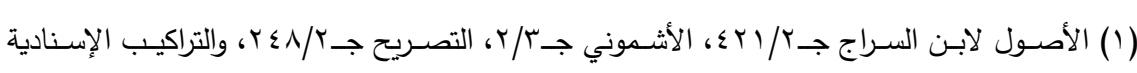

صدی ا.

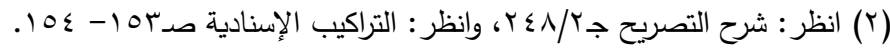

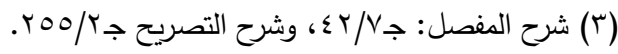


الإسناد والجملة العربيةبين القدامى والهحدثين دراسة تحليلية مقارنة )

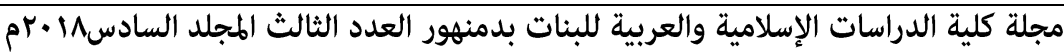

r- لولا: وتفيد تعليق الجواب على الثرط في الزمن الماضي.

ب- لوما: وهي مثل لولا في إفادة تعليق الجواب على الثرط في الماضي.

ع- لما: وتقيد تعليق الجواب على الثرط في الزمان الماضي.

0- إذا: وتفيد تعليق الجواب على الثرط في المستقبل.

7- كيف: وتقيد تعليق الجواب على الثرط في المستقبل أيضًا.

وهذه تنقسهر أيضًا من حيثث التصنيف النحوي إلى ثلاثت أقساهر:

1- حروف باتفاق وهو: لو ولولا ولوما.

r- اسم باتفاق وهو : إذا وكيف وكيفما.

r- ومختلف فيه بين الحرفية والاسمية وهو: لما.

ويالاحظ أن الفرق بين أدوات الشرط الجازمت وغير الجازمت:

ا- أن زمن التعليق الثرطي بالنسبة للقسم الأول الجازم المستقبل دائمـا بغض

النظر عن نوع الصيخ التالية لها.

وهذا هو السـائد في التراث النحوي حتى لو الصسيغة ماضـية أمـا زمن

التعليق الثرطي في القسم الثاني غير الجازم فمتنوع فقد يكون ماضيًا، كما قد

يكون مستقبلا.

ويوضـح هذا أن الأسـاس في زمـن التعليق الشـرطي لهذه الأدوات هو

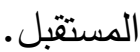

ץ- اختـلاف الحالـة الإعرابيـة بـين أدوات القسـم الأول الجـازم وأدوات القسـم

الثاني غير الجازم فالأولى لها تأثير الجزم فيمـا يعقبها من فعل الثرط أنسا

وفعل الجواب بينما القسم الثاني غير الجازم لا يترك أي تأثير •

ويشير الدكتور على أبو المكارم إلى أن أدوات الشـرط هذه تقتضـي

اتركيبين إسناديين تربط الأداة كـلا منهمـا بـالآخر بحيث يصسيران معًا جملـة

واحدة في إفـادة المعنىى ويطلق على أولها فعـل الثـرط، وقد يطلق عليـه

》الثرط《 اختصسارًا، ويصطلح على ثانيهما 》بجواب الشرطه للدلالة على أنها 


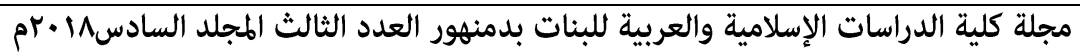
مترتب على الفعل ترتيب الجواب على السؤال، وقد يعبر عنه بالجزاء للإشـارة إلى أن الجواب بمثابة الجزاء لمضمون الفعل.

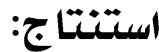
ا- يتشـابه نحاة العصر الحديث مـع نحاة التراث في الاعتمـاد على النماذج العربية في تصوير وتحليل الجملة الشرطية. ץ- رصد التراث النحوي بكل مصداقية موثقة من تصنيف الأدوات سواء من

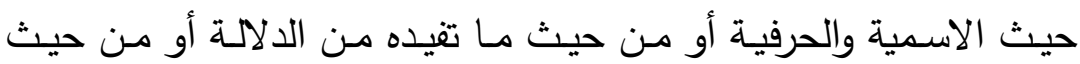
التعليق الثرطي بحسب الزمان أو من حيث إعراب أدوات الشرط. ب- الجملة الثرطية تعد جملة إسنادية ذات تركيب إسنادي مستقل، مكون من تركيبين إسناديين تربط الأداة كل منهما بالآخر بحيث يصيران معا جملة واحدة في إفادة المعنى، وبطلق على أولها فعل الشرط ويطلق على الثاني جواب الشرط مصرح بهذا عند نحاة العصر الحديث. ع- اخـتلاف المحـثثين بـين بعضــهم البعض في نظـرتهم للجملـة الثـرطية باعتبار ركني الإسناد فيها فالدكتور على أبو المكارم أفصـح عن ركني الإسناد في هذه الجملة على اعتبار أن كل تركيب يعد ركنًا إسناديًا فيها فالتركيب الأول وهو فعل الثـرط ركن أول والتركيب الثاني وهـو جـاب الشرط يعد ركن ثانٍ وقد ربطت الأداة بينهما فجاءت الفائدة بعد الربط.

\section{أما اللدكتور مهلي المخزومي فقال:}

اليست جملة الثرط جملتين إلا بالنظر العقلي، والتحليلي المنطقي، أمـا بـالنظر اللغوي فجملتا الشـرط جملـة واحدة، وتعبيـر لا يقبـل الانشـار ، لأن الجزين المعقولين فيها إنما يعبران معا عن فكرة واحدة، لأنك إذا اقتصـرت على واحدة منها أخللت بالإفصاح عما يجول في ذهنك، وقصرت عن نقل ما 


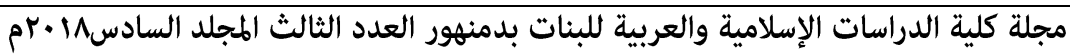

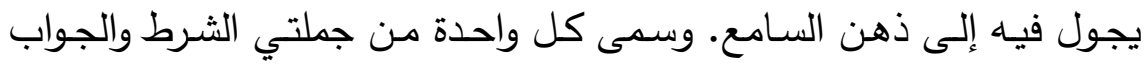
(عبارة) أي عبارة الثرط وعبارة الجوابه"(').

فقد عبر المخزومي عن جملة الثرط- بلفظ العبارة وكذلك عبر عن جملة الجواب بالعبارة، وعنده أن كل منهما على حدى لا يعد جملة مستقلة؛ لارتباط كل منهمـا بالأخرى إذ أن تركيب الجملة الثرطية لا يقبـ الانشطار وفي هذا الكلام توضيح بأن ركني الإسناد في هذه الجملة- العبارة الأولى، مـع ضمتيها العبارة الثانية. والحقيقت أن هذا يتفق مع القدامى ومع الدكتور على أبو المكارم من حيث مراعـاة ركني الإسـناد في جملـة الثـرط حتى يصـدق عليها مصـطلح

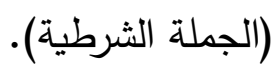

وإن لم يصـرح بـه القدامى حيث اكتفوا بالنمـاذج والتراكيب المشيرة إلى

أنها كيان واحد لا يقبل الانشطار مثلما قال المخزومي. وقد هاجم حماسة(r) المخزومي في قوله بالإسناد ركنا اساسيا في إتمام الإفادة للجملة حيث خذله القول بذلك أمام الجملة الثرطية.

$$
\text { وأرى أنه غير منصف معه. }
$$

لأن حماسة يعترض عليه اشتراط الإسناد؛ لأن كل تركيب من التركيبين في الجملة الشرطية على حدة تم فيه الإسناد ولم تتم فيه الإفادة. وأقول قياس حماسة نموذج الجملة الإسنادية في غير الشرط على حده في الجملة الشرطية يعد قياس مع الفارق. فالأخيرة نموذج يختلف في مكوناته عن مكونات الجملة الإسنادية في غير هذا الباب. 


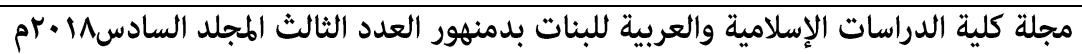
ومن ثم اختلف ركني الإسناد فيها فلا يحق الاعتمـاد على ركن واحد

$$
\begin{aligned}
& \text { أو تركيب واحد فقط لعدم الإفادة الشرطية حينئ. } \\
& \text { تركيب فعل الشرط: }
\end{aligned}
$$

يرصد على أبو المكارم تركيب فعل الثرط من جهة أن النحاة قد فرقوا في التراث بين فعل الشـرط مـع الأدوات الجازمـة، وتركيبـه مـع الأدوات غيـر

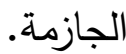

فأشـار إلـى أن جمهور النحـاة يـرى وجوب كونـهـ مـع الأدوات الجازمـة تركيبا إسناديا فعليا مستوفيا لشروط بعينها.

\section{والعلتّ في ذلك:}

أنه بمثابة العلة والسبب لوجود الثاني، والأسباب لا تكون بالجوامد، وإنما

بالأعراض. والأفعال أعراض( (').

والثـائع عند الجمهور أن زمن الفعل بعد معظم هذه الأدوات المستقبل

بصرف النظر عن نوع الصيغة المستعملة منه.

\section{ويفنسر على أبو المهكارور هذا:}

بأن مقتضى هذا التصور عند النحاة أنه لا يكون أي تركيب فعل الثرط تركيبا إسناديا اسميا، على الرغم من ثبوت نماذج ومأثورات لغويـة وقعت فيها بعد أدوات الثرط أسماء؛ إلا أنه يصنف وجود ثلاث اتجاهات بصورة أساسية: أولها: يرى أن الأصل في تركيب فعل الثرط أن يقع عقب أداة الثرط فعل، ومن ثم يؤول ما يرد خلاف ذلك.

والثـاني: يمنـع تأويـل هذه النمـاذج بأن الأسماء مبتدأت بـل يجب أن تكون فاعلًا لفعل محذوف مفسر بالمذكور . 


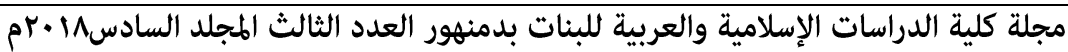

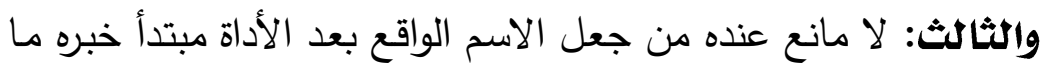

بعـده وبـذلك يجيـز كـون فعـل الثـرط تركيبـا إســاديا مخالفـا الثـائع بـين

النحاة(') نخلص من هذا إلى وجود صورتين في تركيب فعل الشرط:

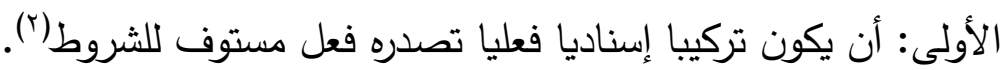

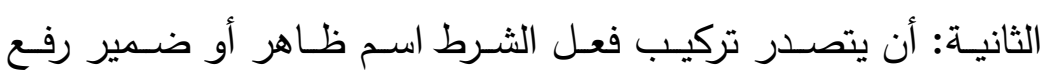

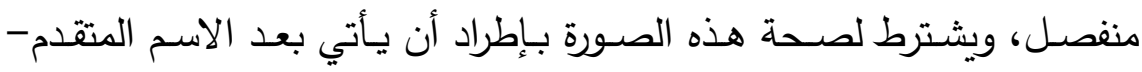
ظاهرًا أو ضميرًا - فعل مستوف للشروط التي سبق بيانها، صسالح للإسناد إلى ما تقدم عليه.

\section{أما ترتيب أفعال الشرط بعد الأدوات غير الجازمت:}

فيشير أبو المكارم إلى أنه يماثل تركيبه بعد الأدوات الجازمـة بيد أنه

ظهر مخالفته لله في أمور أهمها:

الحالـة الإعرابيـة لـه والدلالــة الزمانيـة بـه، ثم بعض الفوارق التي تعـد

بمثابـة صـورة مـن الخصـائص السياقية معـه، لـيخلص مـن ذلك إلى تحديـــ العناصـر الصـالحة للدخول في تكوين تركيب الشـرط بصـورة عامـة وذلك في

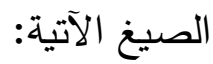

1- التركيب الإسنادي الفعلي، ولا يكون فعله إلا ماضـيًا أو مضـارعًا، ويجب أب

$$
\text { أن يستوفي شروطا بعينها. }
$$

ץ- الاسم الظاهر المرفوع، أو ضمير الرفع المنفصل، ويجب أن يعقب كلا منها فعل مـاض أو مضـارع مستوفي للشـروط، أو وصف مشتق جاري مجرى الفعل في دلالته المزدوجة صالح معنى لإسناده إلى ما تقدم عليه. r- أن المشددة المفتوحة الهمزة ومعمولاها، ويجب ماضيا أو مضارعا مستوفيا للشروط، أو وصفا مشتقا جاريا مجرى الفعل في الدلالة.

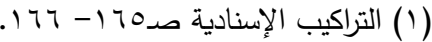

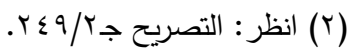




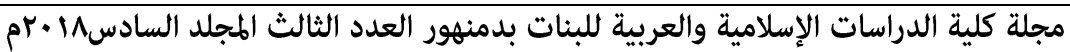
ع- (أن) المصدرية الساكنة النون، ويشترط أن يكون فعلها ماضيًا أو مضارعا مستوفيا للشروط. ه- يندر أن يكون فعل الشرط لفظا ضمير جر متصل، إذا لم يرد ذلك إلا في أداة واحدة هي (لولا) وفي تخريجها خلاف. ج- كمـا ينـدر أن يكون فعل الشـرط المستوفي للشـروط موافقا لفظـا ومعنى للجواب، وقد يشترط ذلك مع أداة واحدة هي كيف. واقتضى ذلك أن يخرج الدكتور على أبو المكارم بأن هناك عدد من

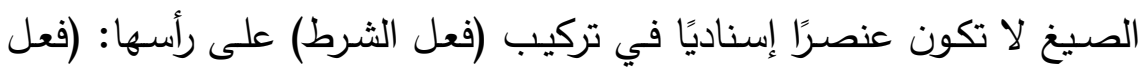
الأمـر )، و(الخوالـف) و(الصـيخ الدالـة على الطلـب) و (الأفعـال الجامـدة) و(الأفعال المقترنة بحرف تتفيس) و(الظرف) و(الجار والمجرور)(').

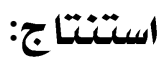

اعتمد الدكتور على أبو المكارم في تحليله لتركيب فعل الشرط: أنه حلله تحليلً عضويا بمعنى أنه فكك تركيب فعل الشرط من حيث الأداة الرابطة بينه وبين الجواب ومن حيث ما وليها من صيغة معتمدًا على النماذج الواردة في التراث النحوي وآراء النحاة الواردة فيها فحدد المكونات والعناصر لهذا التركيب وخلص إلى الصـورة النهائيـة التي يكون عليهـا. فحتم الشـأن أن يفصـل بين أمرين:

الأمـر الأول: تحديد صيخ معينة محددة ورد فيها أو أتى عليها فعل الشـرط فرأينـاه قد يكون فعـلَ ماضـيًا أو مضـارعًا وكل هـا مشـروط بشـروط

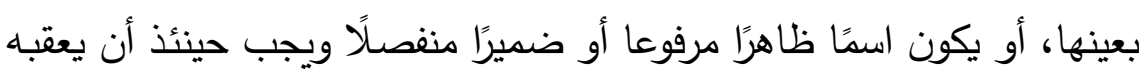
فعل ماضي أو مضارع مستوفي للثروط. وقد يكون صيغة التركيب بعد الأداة (أن) المشددة ومعدولاها ويجب أن مهئ يكـون خبرهـا فعـلً ماضـيًا أو مضـارعا مسـوفيا للشـروط وينـدر مجيئهـ (أي 


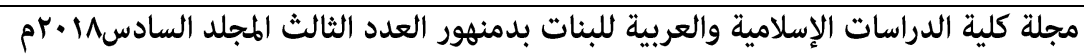
تركيب فعل الثرط) لفظا ضمير جر منفصل وقد ورد ذلك في أداة واحدة وهي (لولا)، كما أنه ندر أن يكون فعل الشرط موافقا لفظا ومعنى للجواب وقد اشترط ذلك مع (كيف) فقط. الأمـر الثثاني: تحديد الصيغ التي لم ترد في تركيب فعل الثرط من نحسو: فعل الأمـر، الخوالف، الصـيخ الدالـة على الطلب، والأفعـال الجامـدة، والأفعال المقترنة بحرق تنفيس، والظرف، والجار والمجرور وقوفًا على النماذج الواردة من التراث اللغوي النحوي.

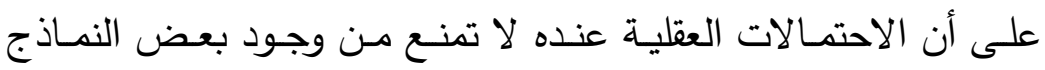
النمطية المخالفـة كما في نحو: إن كان حمد سيحضر فاستقبله، في حين لا يجوز : إن سيحضر ححم سأستقبله، ونحوه: إن كان الزميل في الكلية فسأقابله، مدا يشير إلى أن لوجود (الفعل الناسـخ) دورًا ضـمن تركيب فعل الشرط في إجازة هذه النماذج.

\section{تركيب جواب الشرط:}

يثير الدكتور على أبو المكارم إلى مكونات تركيب جواب الثرط في التراث النحوي لتقرر النحاة أن الأصـل في التركيب أن يكون تركيبا إسناديا فعليـا الأن الجـواب شـيء موقوف دخولـه في الوجـود على دخـول شـرطه،

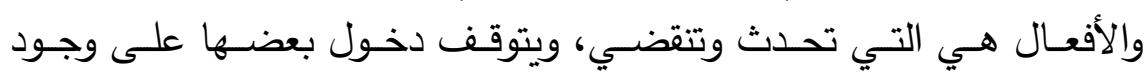
بعضع (')

إلا أنه يرى أن النصوص اللغويسة أوسـع من هذا دائرة وأكثر تتوعًا، إذ إذ أن ورد جواب الشرط فيها تركيبا إسناديا فعليا، كما ورد أيضًا تركيبا إسناديا اسميا، وكذلك ورد تركيبا شرطيا.

والشرط الأساسي في جواب الشرط أن يكون مفيدًا، فلا يصـح الجواب بما لا يفيد، وهكذا لا يجوز نحو: (إن يقم زيد يقم) كما لا يجوز في الابتداء (زيد زيد)

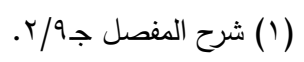




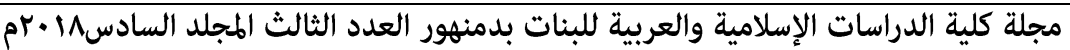
ليصل إلى أن الإطار العام لمكونات جواب الثرط توجد فيه أدوات تقبل جميع الاحتمالات الممكنة لتركيب هذا الجواب، فمن الممكن أن يكون تركيبا

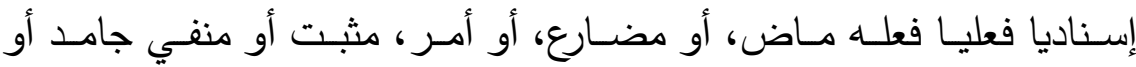
متصرف، مقترن بقد أو بحرف تنفيس أو مجرد منهما، خبر أو إنشاء كما أن من الممكن أن يكون تركيبا إسناديا أو ظرفيا مثبتا أو منفيا خبرًا أو إنشاء.

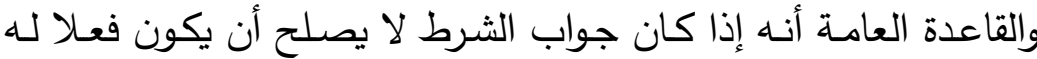
فإنـاه يجـب أن يقترن بالفـاء، وخصـت بـذلك عند النحـاة؛ لأنهـا تفيد السببية، ولمناسبتها للجزاء في المعنى، إذا معناهـا التعقيب بـلا فصل، كمـا أن الجزاء

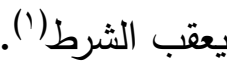

إذ يرى بعض النحاة أن هذه الفاء الرابطة هي فاء السببية الكائنة في الإيجاب في نحو قولك: (يقوم كمح فيقوم خالد) وكما يربط بها عند التحقيق يربط بها عند التقدير، ومن ثم لا يجوز الربط بين تركيبي الثرط والجواب بغيرها إذ هي هنا للربط السببي وليس للتشريك في الحكم ومنهم من يرى أن هذه الفـاء هي العاطفـة وأنها تعطف (جملة) على (جملة) أي تركيبا إسناديا

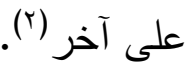

ويعرض الدكتور على أبو المكارم لمكونـات جواب الثـرط من خـلال النماذج الواردة في التراث النحوي ليصل إلى نتائج وهي: أن التركيب الإسنادي الفعلي كـان أكثر صـلاحية لوقوعـه جوابـا مـن التركيـب الإسـنادي الاســي أو الظرفي، إذ إنه يمكن أن يقع جوابا لكل أدوات الثرط، جازمة وغير جازمة، في حين أن التركيـب الإسـنادي الاســي أو الظرفي لا يجـوز وقوعـه جوابـا

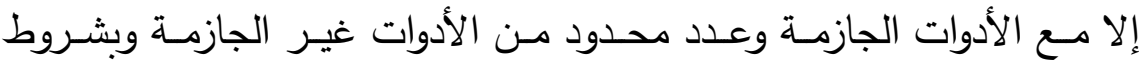


الإسناد والجملة العربيةبين القدامى والهحدثين دراسة تحليلية مقارنة )

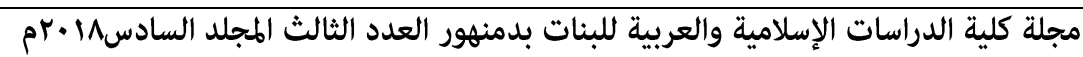
الظمواهر السياقيت للجملث الشرطينّ:

تعددت الظواهر السياقية في الجملة الثرطية وقد رصدها الدكتور على أبو المكارم من نحاة العصر الحديث وحللها تحليلً لفظيا ومعنويـا ليصل إلى خصائص تركيب هذه الجملة فكان من هذه الظواهر :

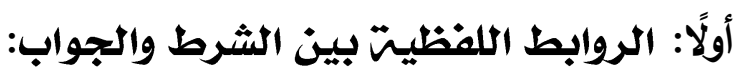
حيــث قسـمت أدوات الثـرط إلـى قسـمين أدوات جازمــة وأدوات غيـر جازمة.

\section{أما قسهر الأدوات غير الجازمهّ:}

فإنها بصورة عامة لا تستخدم إلا أسلوبا واحدًا، و وهو الذي يعتمد على وجود الصيخ الرابطة.

\section{وأما قسير الأدوات الجازمه:}

فأن الرباط اللفظي بين الشرط والجواب يكون واحدًا من أمرين الجزم،

$$
\text { أي الشكل الإعرابي، ووجود الصيخ. }
$$

- فالجزم حالة إعرابية يعتد بها عند النحاة علامـة على الارتباط الفظي بين الشرط والجواب ويظهر عندما يكون الفعلان مضارعين فإن لم يكونا كذلك

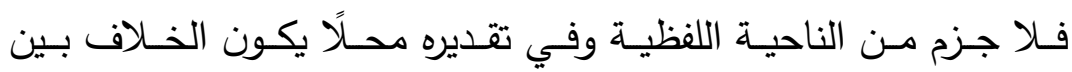

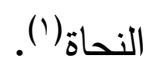

ويعترض الدكتور على أبو المكارم على مثل هذا الخلاف الذي يصحبه التقديرات عند النحـاة وذلك لتضـاربـه مـع الضـوابط المقررة نحويـا مـن ناحيـة وفقدانه المسوغ من ناحية أخرى. 


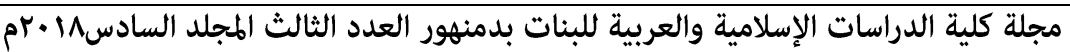
ومن هنا اعتمد الدكتور على أبو المكارم على اعتبار الجزم رباطسا لفظيا إذا كان موجودا بالفعل في الشرط والجواب أو في أحدهما وذلك متى توافر فيهما عدد من الثروط الدوان. - أما الشرط فيجزم وجوبا إذا توافر فيه هذه الشروط بأن يكون:

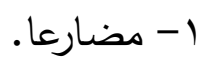

r- ألا يكون ماضي المعنى. ب- ألا يكون طلبيا. ع- ألا يكون جامدًا.

0- ألا يكون مقرونا بحرف تنفيس وهو السين أو سوف. צ- ألا يون مقترنا بحرف نفي غير لم. - ألا يكون مقترنا بقد. - V

- أمـا الجواب فالجزم فيها واجب في حالات وممتنع في حالات وجائز في حالات.

\section{فيبجب الجززو في التجواب:}

إذا تحقق في الجملة الثرطية بأسرها أمران: أن أن يكون الثرط مضارعًا مجزومًا. r- أن يتوافر في الفعل الواقع في جواب الشرط الشروط التي سبق ذكرها في فعل الثرط.

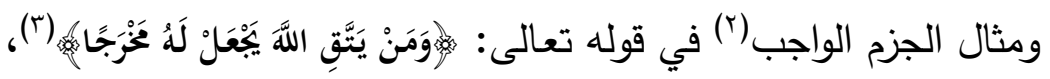
وشذ رفع الجواب مع تحقق الثروط نحو قول الثاعر : يا أقرع بن حابس يا أقرع ... إنك إن يصرع أخوك تصرع|(

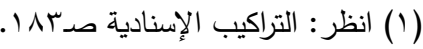

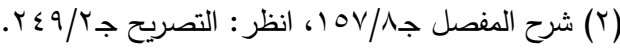

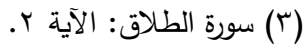

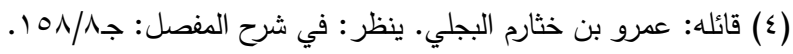




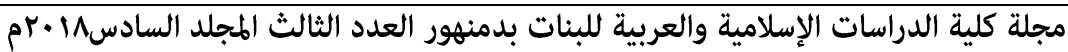
ويمتنع الجزم مـع كون الفعل الواقهع في الجـواب مضـارعا- إذا كـان طلبيا، أو ماضي المعنى، أو جامدًا، أو مقترنًا بحرف تتفيس أو بقد، أو بغير

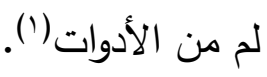
فتقـول على الرفـع في الجـواب: إن يحضـر الصـديق لا أتـأخر في أني استقباله، ومن يناضل دفاعا عن الحق ما أتوانى في تأييده، ومن ذلك قوله

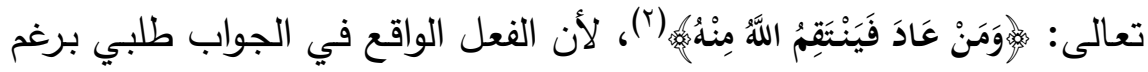
وقوعه مضارعا.

ويجوز الجزم وعدمه- وهو الرفع- إذا تحقق في الجملة الشرطية أمران:

1- أن يكون فعل الثرط ماضيا. r- أن يتوافر في الفعل الواقع في الجواب الثروط السابقة.

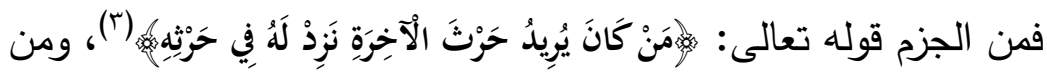

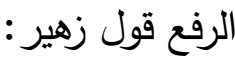

وان اتاه خليل يوهر مسألت ... يقول لا غائب مالي ولا حره (ء) - الأدوات الرابطن: لاحظ الدكتور على أبو المكارم أن الأدوات الرابطة للقسم الأول كلمتان (الفاء) و (إذا) الفجائية. أما (الفاء) فإنها تدخل على صدر الجواب إذا كان لا يصلح أن يكون

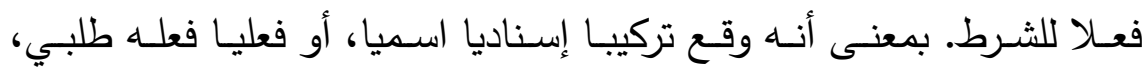
أو جامـد، أو منفـي بــا، أو بلـن، أو بـان النافيـة، أو مقترن بقيـــ أو السـين أو بسوف. بالإضافة إلى معناها من إفادتها للتعقيب بلا فصل والجزاء يعقب الشرط فضلا عن كونه نتيجة له.

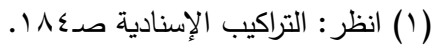

$$
\begin{aligned}
& \text { (Y) سورة المائدة: الآية } 90 .
\end{aligned}
$$

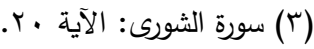

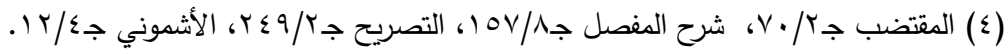




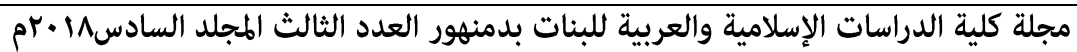
وأما (إذا) فإنها تربط في حالة واحدة وذلك إذا كان جواب الشرط تركيبا إسناديا اسميا موجبا غير طلبي، وغير مقترن (بأن) المؤكدة، شريطة كون أداة الثرط (إن) ونحوها.

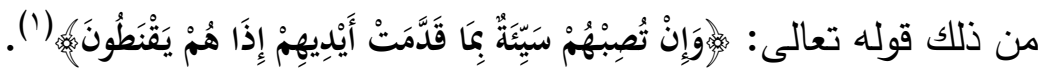

\section{أما الأدوات الرابطنّ في القسه الثاذي غير الجازهر:}

مـا عدا (إذا) فتشـارك أدوات الأول الجـازم في الـربط (بالفـاء) أو (إذا

الفجائية) وما عدا (لما وكيف) اللذان يخلو جوابهما من الأدوات الرابطة جملة، فكانت أدوات هذه القسم الثاني غير الجازم تحتاج إلى روابط لفظية وهي لو، لولا، ولومـا، وهي جميعًا تستخدم (الـلام) وحدها دون غيرها من سـائر أدوات الربط بين الشرط والجواب. ولوحظ أن هذه اللام ليست واجبة الوجود في جميع الحالات وأن من الممكن الاستغناء عنها.

وخلص الدكتور على أبـو المكـارم مـن عرضـهـ هـا إلى أن الـروابط اللفظية بين الشرط والجواب تتمثل في أحد أمرين: ا- التوافق في الحالة الإعرابية.

r- استخدام إحدى الأدوات الرابطة الثلاثة، (الفاء، وإذا، واللام) ولكل منهما مواقعها الخاصة بهاب(r).

\section{ثانيًا : الترتيب الجملي في الجملتش الشرطينّ:}

أشار الدكتور على أبو المكارم أنه من المقرر والثابت عند النحاة أن

أداة الثـرط هـي الأداة التي تقوم بوظيفـة التعليق المعنـوي والزمنـي معـا بـين

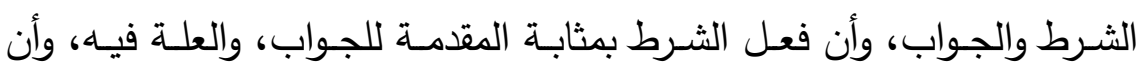
الجواب هو النتيجة الحتمية له، والمعلول الضروري الذي لابد منه. 


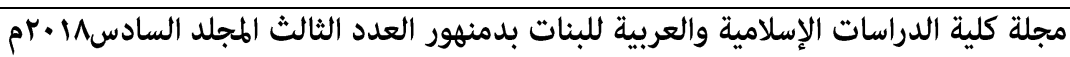

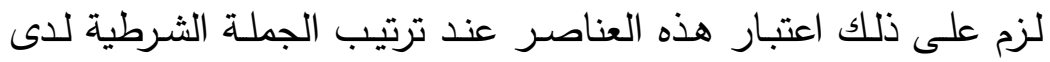
النحاة فيلزم أن تقدم الأداة الثرط ويليها فعل الثرط، ويعقبه الجواب، ووـا قد يكون لله من معمولات. إلا أنه ورد كثيرًا من الصور التي خالفت هذا الأصل العام في التراث اللغوي. مما أثار الجدل عند النحاة حول هذه النماذج مما دعاهم إلى الأخذ بتأويل النصوص التراثية حتى تسلم لهم القواعد في الصور الآتية: ا - تقدم ما يشعر بالجواب على الأداة('). r- تقدم معمول الجواب على الأداة(r). r- الفصل بين الفعل والجواب(r). ثالثًا : الدحذف والذّكر:

يرصـد الـدكتور على أبـو المكـارم مـن الظـواهر السـياقية في الجملـة الشرطية: أن الأصسل فيها أن نذكر عناصـرها الثلاثة من الأداة وفعل الثرط وجـواب الشـرط ولكن ظهر في التراث اللغـوي مـا يكشف عـن مخالفـة هـذا الأصسل. فيمكن الاستغناء عن بعض هذه العناصر متى دل عليها دليل من الموقف أو السياق، ومن ثم تقرر لدى النحاة إمكان احذف أحد العناصـر الثلاثة بل تجاوز الحذف إلى حد إمكان حذف كافة العناصـر التقاء بما يدل عليه في السياق أو الموقف. فكانت هناك للحذف في التراث النحوي صورًا منها: ا- حذف فعل الثرط والجواب معًا(£). r- حذف أداة الشرط وفعل الشرط(0).

$$
\begin{aligned}
& \text { (1) انظر : شرح المفصل ج99/ } 9 .
\end{aligned}
$$

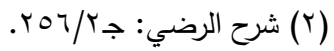

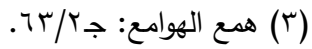

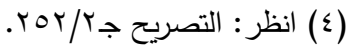

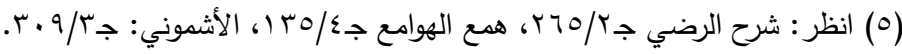




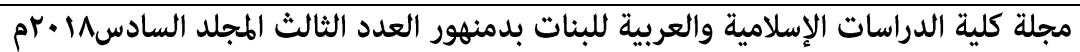

$$
\text { ع- ع- حذف فعل الشرط وحده('). }
$$

\section{رابعًا : الفصل بين فعل الثرط وجوابه:}

أيضًا من النصسوص المقررة التي أشـار إليها الدكتور على أبو المكارم اتباعا للنماذج المأثورة في التراث أن تتوالى أجزاء الجملة الثرطية.

بيد أنـه قد ورد مـن النصـوص مـا يشير إلى إمكان الفصـل بين فعل الشرط وجوابه، لتأخذ هذه النصوص صورًا لكل واحد منها أحكاما تختلف عن إن

$$
\text { غيرها من الصور الأخرى، وهي: }
$$

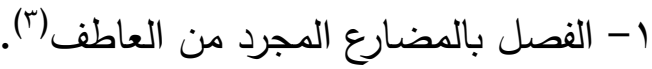

r- الفصل بالمضارع المعطوف (بالفاء) أو (الواو) أو (حتى) أو (أو)(؛). ب- الفصل بالمضارع المقترن بغير أدوات العطف السابقة. على نحو المقترن

$$
\text { بثم. }
$$

الصـورة الأولى: مضـارع مجـرد مـن أدوات العطف نحـو قولـه تعـالى :

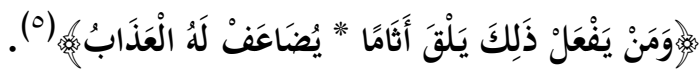

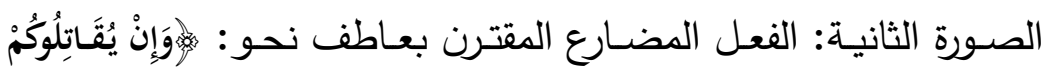

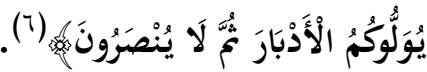

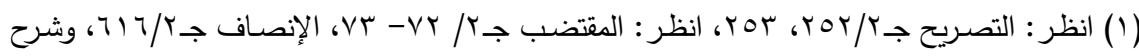

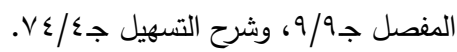

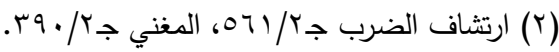

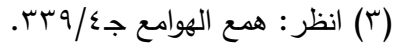

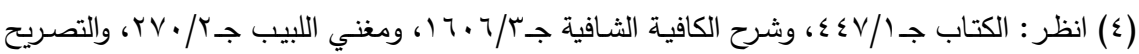

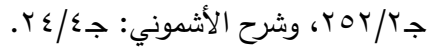

$$
\begin{aligned}
& \text { (0) سورة الفرقان: } 11 \text { (7) } 79 .
\end{aligned}
$$

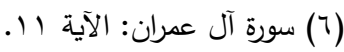




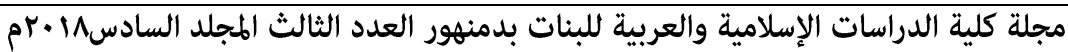

\section{سادسًا: تعلد : ثعل الشروط:}

من الظواهر السياقية التي رصدت عند الدكتور على أبو المكارم في تحليل الجملة الشرطية أن من الأساليب الواردة في التراث اللغوي؛ تعدد كل من أداة الشرط وفعله والاقتصـار بعدها على جواب واحد، وقد ورد في الأسلوب كوب

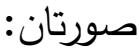

الأولى: ذكر أداة الشـرط الثانيـة دون عطف، والثانيـة ذكر الأداة بعـد

عاطف، ولكل منهما أحكاما خاصة عند النحاة('). مثال تعدد الشرطين أو أكثر دون عاطف قول الثاعر :

\section{إن تستغيثوا بنا إن تذعروا تجد وا ... منا معاقل عز زانها كرهر(r)}

فالجمهور على أن الجواب من حيث المعنى -جواب الشرط الأول، وأما الشرط الثاني فإن جوابه محذوف دل عليه جواب الأول. والشرط الثاني مقيد لما في الشرط الأول من إطلاق، فهو يؤدي من حيث المعنى وظيفة الحال.

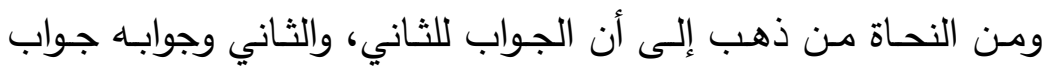
للأول على إضمار الفاء.

واتبع أبو المكارم القول الأخير بأنه لا يسلم من ضعف(r). أمـا مثال الصـورة الثانية تعدد الثروط مـع اقترانها بعاطف. فقد اعتذر الدكتور على أبو المكارم للتمثيل عنها لعدم توافر نصوص تراثيـة بين يديـ يشهد بذيوع هذه الصورة.

وفي رأيه أن النحاة قد عرضوا لها استكمالا للاحتمالات العقلية الواردة لهذا التعدد. نحو: إن تحضر ، وإن تتاقش تفهم الدرس، وإن تحضر ثم تـاقش

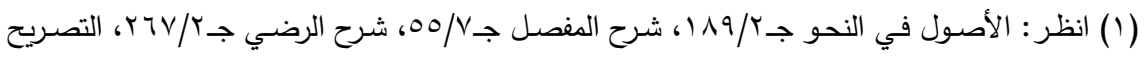
ج

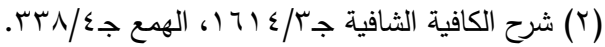

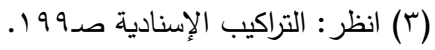




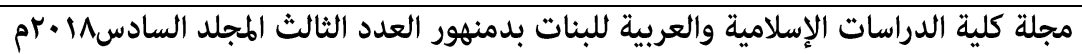

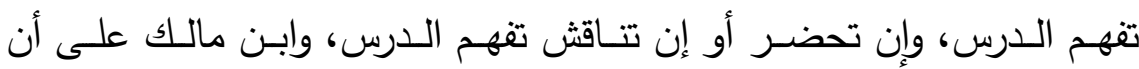
الجواب للشرط الأول بصرف النظر عن الأداة العاطفة أو غيره. وعند غيره مـن النحـاة فيـه تفصيل باعتبـار نـوع الأداة العاطفـة ليخرج الدكتور على أبو المكارم عن هذا الخـلاف بأن الإسراف في التفصيل على الرأي الثاني لا جدوى منه فدلالات النصوص تؤيد رأي ابن مالك من ضرورة رعاية أداة العطف في النص اللغوي(1). سابعًا : اجتماع الشرط والقسهر:

يحتاج القسم إلى جواب كما يحتاج فعل الثرط إلى جواب، إلا أن روابط القسم تختلف عن روابط الثرط التي تربطه بغعل الثرط فكل منهما له روابطه اللفظية.

\section{أما روابط فحل القسه اللفظطيته(؟) فهي:}

ا - يؤكد الجـواب بـ (إن، والـلام) إذا كـان تركيبـا إســاديا اسـميا أو ظرفيـا، أو وصفيا معًا نحو: (والله إن خالدا لفي قلوبنا) أو يؤكد بواحدة منهما نحو:

$$
\text { (والله لخالد في قلوبنا) أو (والله إن خالدًا في قلوبنا). }
$$

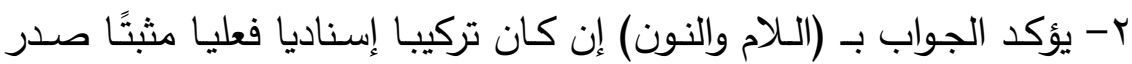
بمضارع نحو: والله لنكرمن ذكرى شهدائنا.

ب- يؤكد الجـواب بـ (الـلام وقد) إن كـان تركيبـا إسـناديا فعليـا مثبتًا صـدر بماضي أكد بـ (اللام وقد) نحو: والله لقد نهض خالد بواجبه. ع- ويؤكد الجواب بـ (ما) أو (لا) أو (إن) إن كان التركيب الإسنادي منفيا. نحو: والله ما أهمل المناضلون ونحوه. 
الإسناد والجملة العربيةبين القدامى والهددثين دراسة تحليلية مقارنة )

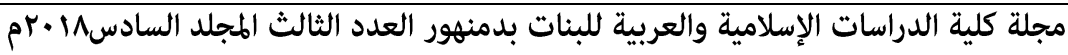
واجتمـاع الشـرط والقسـم ثابـت لغويـا فمن الممكن في الجملـة العربيـة يجتمـع فيهـا الشـرط مـع القسـم. ولا سـبيل عمليـا لذكر الجـوابين معًا بـل يلـزم الاقتصار على ذكر أحدهما والاستغناء به عن ذكر الآخر . أما لمن الجواب فثيه تمثيل: ا- إذا كانت أداة الشـرط (ثـو أو لـولها )فيرى الجمهور جواز أن يكون الجواب لأي منهمـا، سـواء تقدم القسم على الثـرط أو تقدم الثـرط على القسم.

تقول: والله لو قام زيد لم يقم عمرو، بذكر جواب الشرط، وتقول: والله لو قام زيد لا يقوم عمرو، بذكر جواب القسم وكذلك لو تقدم الشرط. وإذا كانت أداة الشرط غير (لو ولول) يمرق بين صورتين: الأوكى: إذا تقدم في التركيب اللغوي ما يحتاج إلى خبر كالمبتدأ في الحال أو في الأصل. والثانيت: إذا لم يتقدم في الجملة ما يحتاج إلى خبر • فاله فإذا تقدم مـا يحتاج إلى خبر فالجواب عند النحاة ذكر جواب الشرط وحذف جواب القسم سواء كان الشرط متقدما، نحو: زيد إن حضر خالد- والله أكرمه، أو متأخرًا، نحو: زيد والله- إن حضر خالد أكرمه. وإذا لم يتقدم مـا يحتاج إلى خبـر حذف جواب المتأخر منهمـا لدلالـة جواب المتقدم عليه('). نحو: (إن قام زيد - والله- يقم عمرو) فالجواب للشرط لتقدمه (والله إن قام زيد ليقمن عمرو) فالجواب للقسم لتقدمه. وهناكك مسائل ختاميـت رصلدها الدكتور على أبو المكـارو في ظل الظواهر السياقيت لجملتش الشرط وهي: ا - زيادة ما على أدوات الشرط وبخاصة على ('): 


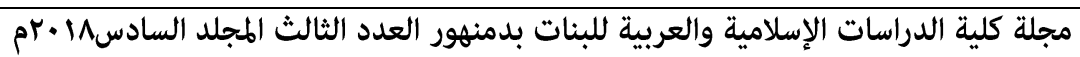

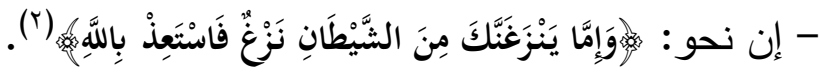
- أي شريطة ألا تكون مضافة إلى ضمير نحو قوله تعالى :

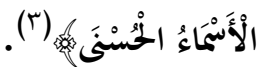

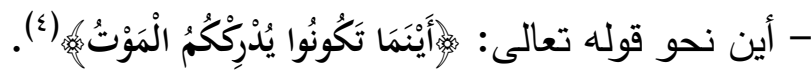
- أيان نحو قول الثاعر :

إذا النعجه الأدماء كانت بقفرة ... فأيان ما تعدل بها الريع تنزل (ه) - متى، نحو قول عنترة:

\section{متى ما تلقني فردين ترجف ... روانف أليتيك وتستطارا} على أن (ما) هذه تزد في هذه الأدوات بغية توكيد المعنى العام المستفاد من الجملة.

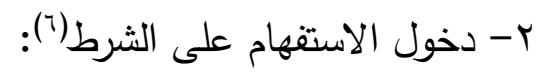

ذهب سييويه إلى أنه يجب تقدم الاستفهام حينئذ على أداة الشرط، لأن

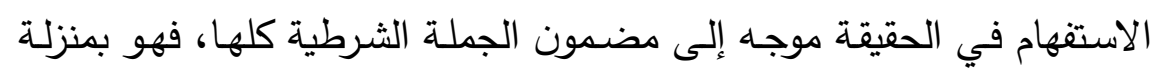

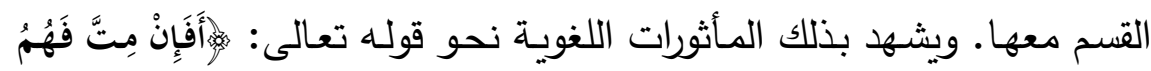

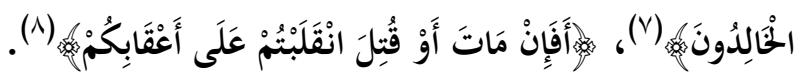

$$
\begin{aligned}
& \overline{=}
\end{aligned}
$$

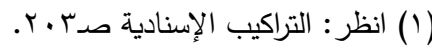

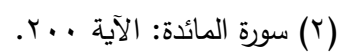

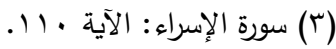

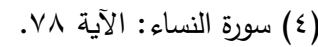

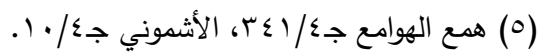

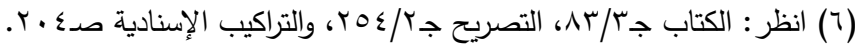

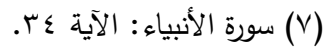

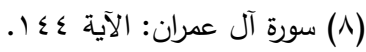




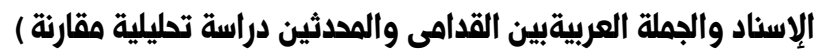

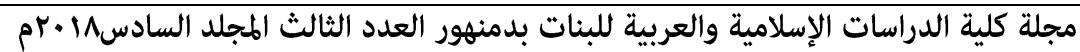

$$
\text { ب- الجزم بعد الأدوات غير الجازمة (') }
$$

ورد من المأثثرات النحوية ما أشارت إلى وجود جزم بعد التهد الأدوات الغير

جازمة فيما أتبعها من أفعال واختلفت الآراء النحوية حول تخدية التهريجها.

وذلك بعد (إذا) في قول النمر بن تولب:

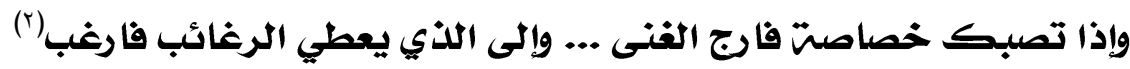

$$
\text { وقول عبد قيس بن حقاف بن عمرو: }
$$

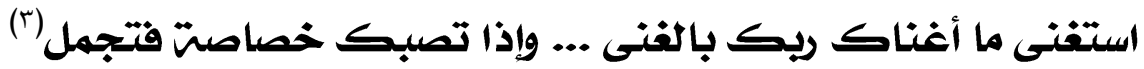

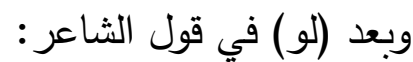

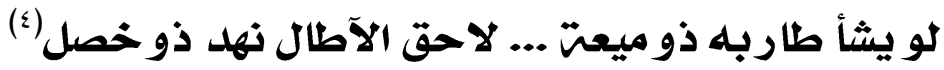
بجزم يثأ. ع - الثرط بدون الأداة(0):

وهو على وصف الدكتور على أبو المكارم أسلوب من جزأين:

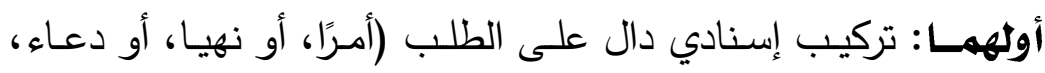
أو استفهاما، أو عرضا، أو تخصيصا، أو تمنيا، أو رجاء).

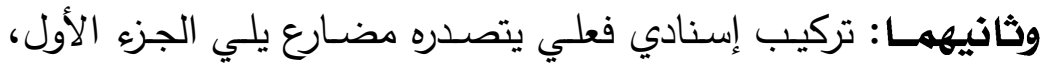

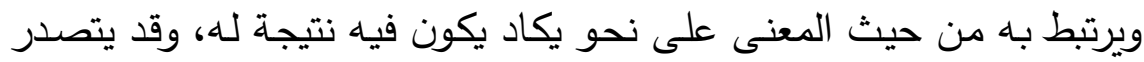

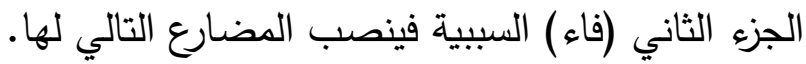

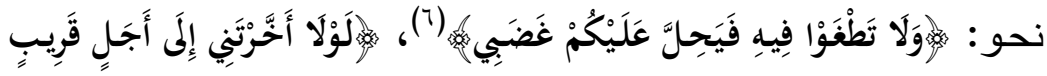

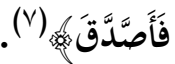

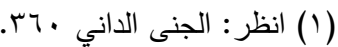

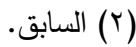

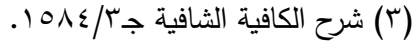

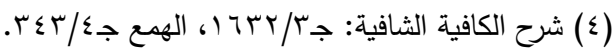

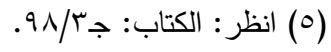

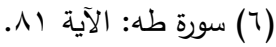

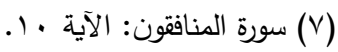




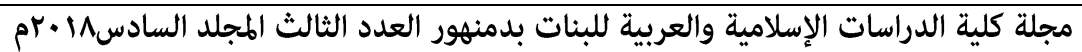

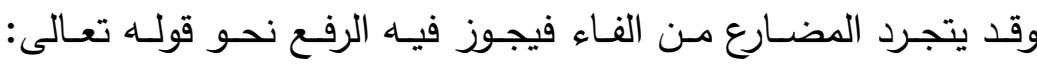

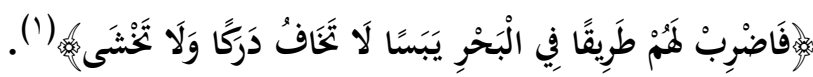

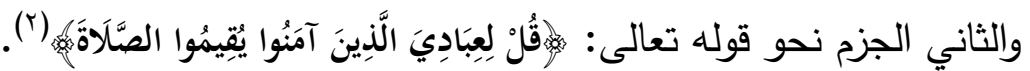
واختلف النحاة حول توجيه الجزم ليحزم الدكتور على أبو المكارم إلى أن الخصائص السياقية لكل من الأسلوبين تفرض عدم حمل أحدهما على الآخر وتوجب تقسير الحالـة الإعرابيـة لكل منهمـا في ضـوء الوظيفـة النحويـة التي تؤديها الكلمات في تركيبها اللغوي. ولا مانع عنده من القول بأن الجازم هنا أسلوبي، بمعنى أن 》الموقع) هو الذي أثر فيه، وليس كلمات بعينها منه(ب). خصائص الجملم الشرطيت:

استطاع الدكتور على أبو المكارم أن يحدد الخصـائص التي يتميز بها تركيب الجملـة الثـرطية وذلك من خـلال تحديد موقفها مـن ظواهر البسـاطة والتركيـب والتقييد أو النسـخ، والامتداد، والتطسابق، والترتيب، وذلك بمقارنتها بصورة عامة بمواقف غيرها من الجمل.

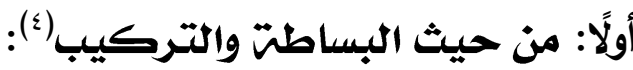
اختلفت الجملة الثرطية في نموذجها عن نماذج الجملة العربية سواء من حيث طبيعة الإسناد أو شكله أو الأطراف المشاركة فيه.

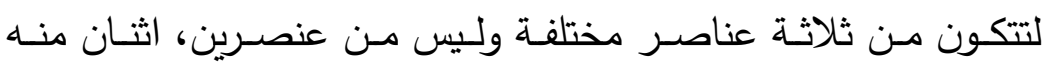
تركيبان إسناديان متميزان مترابطان عضويا لفظا ومعنى. والعنصر الثالث هو الأداة التي تقوم بمهمة الربط الحيوي الضروري بين التركيبين الإسناديين. 


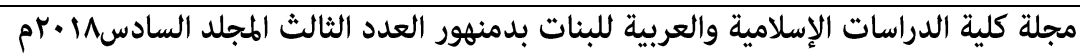

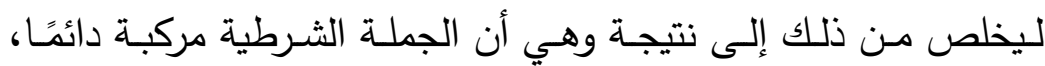

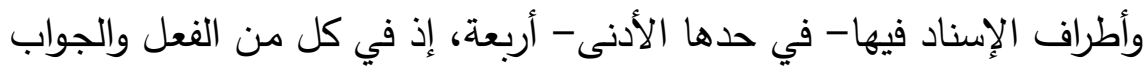
طرفان إسناديان.

فالتركيب فيها ذو طبيعة خاصة يخالف فيه التركيب في غيرها من حيث يمكن أن تكون أطراف الإسناد في الجملة المركبة غير الشرطية ثلاثة فحسب. وبهذا يتبين أن الجملة الثرطية تخالف سائر النماذج النمطية لبقية أنواع الجملة العربية سواء منها ما اتسم بالبساطة، أو ما اتسم بالتركيب.

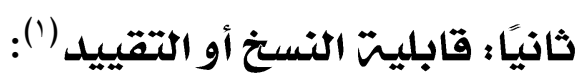
يصل الدكتور على أبو المكارم إلى الحكم على الجملة الشرطية في مجموعها باعتبارها نموذجا تركيبيا متكاملا- أنها لا تقبل التقييد بأي نوع من النواسـخ الحرفيـة أو الفعليـة، ولكـن كـلا مـن طرفيهـا الإسـناديين: مـن الفعـل

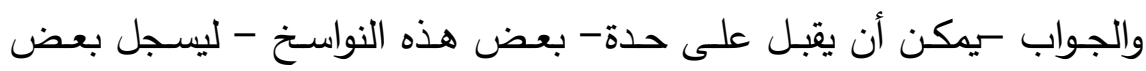
الملاحظات حول الأساليب الواردة وهي:

ا- أن النواســخ الصـالحة للـدخول على أحـد التـركيبين الإســاديين للجملـة الشرطية محصورة في نطاق النواسخ الفعلية دون الحرفية. ץ- أن من النواستخ الفعلية مـا لا يصلح لتقييد الفعل في حين يجوز أن يقيد الجواب، كما أن منها ما يقيد الفعل وحده دون الجواب.

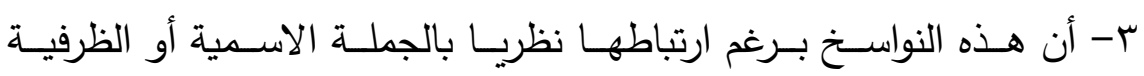
وبالتراكيب الواردة لهما. فإنها حين تدخل في نسيج الجملة الشرطية تعامل معاملة الأفعال التامة. ويصـل بـلك إلى أن الجملـة الثـرطية ذات وضـع خـاص فيمـا يتعلق بالاستخدامات السياقية للقيود الجملية(r). 


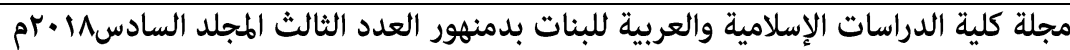

\section{ثالثًاء : قابلينة الامتد اد (')}

يصـف الـدكتور على أبـو المكارم الجملـة الشـرطية بأنها لا تقبـل في

مجموعهـا الامتـداد، وعناصـرها الثلاثـة مـن الأداة والفعـل الثـرطي والجـواب تتصف بالثبات، ولا تقبل الزيـادة، إلا أن كـلا من الطرفين الإسـاديين فيها-

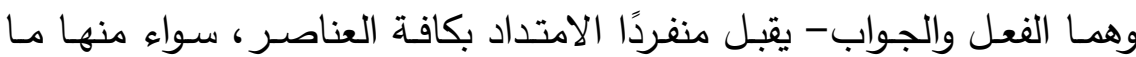
اتصف بـالعموم كالظرف، والجـار والمجرور ، والحسال أو اقتصـر على وجـود العنصر الفعلي، كالمفاعيل. ليصل إلى نتيجة تقتضـي أن الجملـة الشرطية متميزة حجما في حدها الأدنى، وفي حدودها القصـوى وفقـا للاحتمـالات الممكنـة الأمـر الذي يمثل

خصيصة من خصائصها.

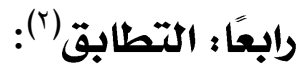

يذكر الاكتور على أبو المكارم أننا إذا وضعنا في الاعتبار أن كلا من (الفعل) و(الجواب) يمثل طرفا إسناديا في الجملة الشرطية، فإن من الثابت أنه لا يوجد في هذه الجملة تطابق ما، سواء من الناحية العددية أو النوعية، إذا يمكن أن يكون (الفعل) فيها مفردًا مذكرًا و(الجواب) لا إفراد فيـه ولا تذكير؛ لأن كلا من الفعل والجواب تركيب إسنادي منفصل في مبناه عن الآخر • ولكن

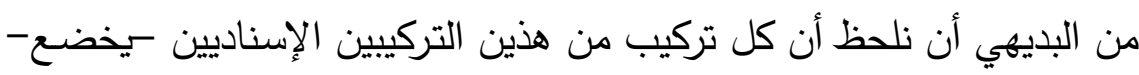
منفردًا للضـوابط المقننة للتطابق وفقا للتصنيف الذي ينتمي إليه، سواء كان تركيبا إسناديا اسميا، أو ظرفيا، أو فعليا.

وبهذا يظهر لنا تميز الجملة الشرطية في موقفها من التطابق عن بقية أنواع الجملة العربية. 


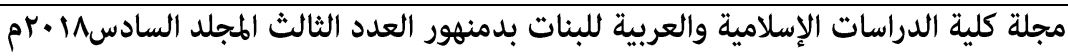

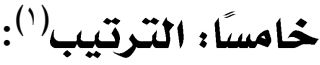

يلحظ أنه من الثابت لغويا اطراد ظاهرة الترتيب في الجملة الشرطية بين

عنصـرين مـن عناصـرها الثلاثتة وهذا العنصـران الأداة والفعـل، وأنـه لا مجـال لتقدم الفعل على الأداة، وهذا ما تقرر في التراث النحوي بيد أن ثـة فرق بين ما ثبت لغويا وما تقرر نحويا فيما يتصل بتحديد موقع الجواب في الجملة، فان النصوص الواردة في التراث اللغوي تتبئ عن تقدم الجواب على الأداة والفعل معا، وإن لم تتتج تقدمـه على الفعل وحده، وهو مـا أخذ بـه بعض النحاة أمـا الجمهور فيوجبون تأخر الجواب عن الفعل وعدم تقدمـه في الجملة بأي صورة من الصور وهكذا إذا أخذنا بالمقرر نحويا تكون الجملة الثرطية واجبة الترتيب في مجموعها. أما إذا راعينا الثابت لغويا فإنها تكون ملتزمة الترتيب بين عنصرين من عناصرها مرنة الترتيب في تحديد موقع العنصر الثالث فيها. استنت:ا ج:

يستتج من تحليل الدكتور على أبو المكارم للجملة الشرطية أنه:

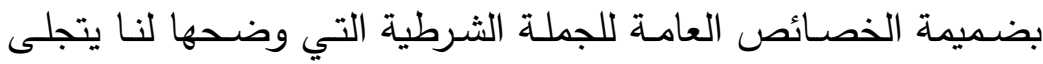
تميز هذه الجملـة بـمط خـاص متميز عن أنماط الجملـة العربية، سواء في في

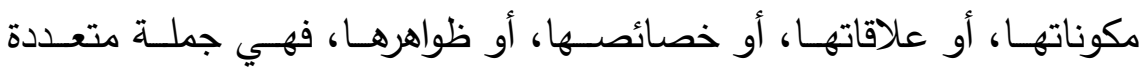

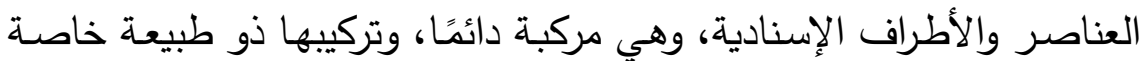
بها، وليست في مجموعها صـالحة للنسخ أو الامتداد أو التطابق، إلا أن كلا من النسخ والامتداد والتطابق أمر وارد بالنسبة للطرفين الإسناديين فيها، وهي من -ناحية- ملتزمة الترتيب، ثابتة الموقع، ومن ناحية أخرى، تتسم بقدر من مرونة الترتيب في مجال تحديد موقع أحد عناصرها، وبرغم هذا تعد نوعان من من أنواع الجملة العربية مختلفًا عما سواه(r). 


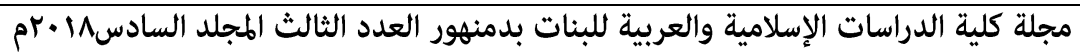

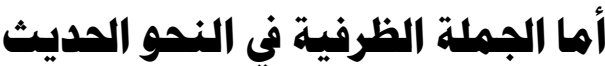

فعلى الرغم من استخدام مصطلح الجملة الظرفية في التراث النحوي بين المتقدمين والمتأخرين منهم إلى أن هذا المصطلح كتب لـه التـاول مـع نحاة

$$
\text { العصر الحديث('). }
$$

فقد اعترفوا بوجـود 》الجملـة الظرفيـةه كيانًا مستقلًا مـن أنـواع الجملـة العربية. يستند إلى طبيعة المقومات التي تتوافر في هذه الجملة والخصـائص التي تميزها وهي مقومات وخصائص تتتهي إلى ضرورة الإقرار بأن الالجملة

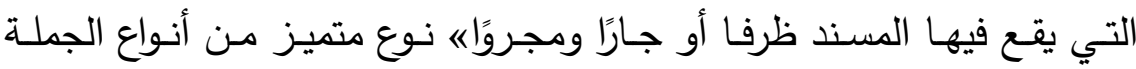

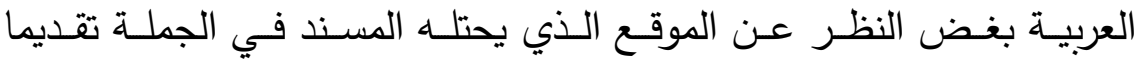
أو تأخيرًا، وعن السياق الذي يستعمل فيه خبر أو إنشاء.

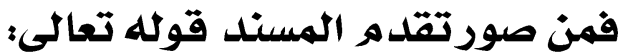

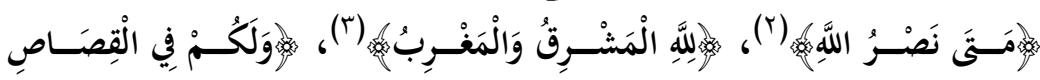

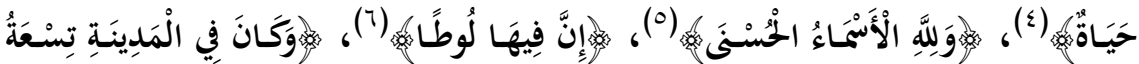

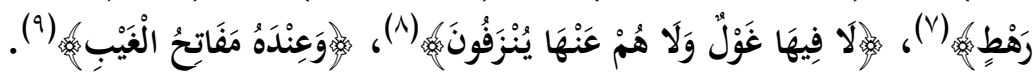
ومن صورتأخر المسند قوله تعالى: (1)

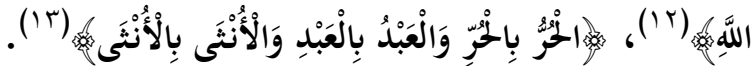

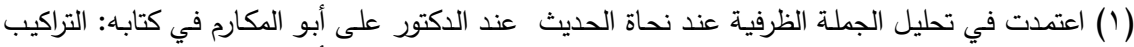

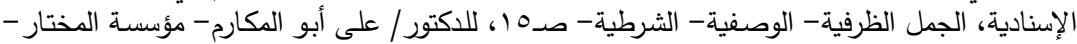
القاهرة. ( البقرة: (Y)

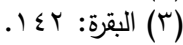

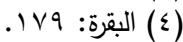

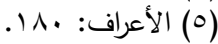

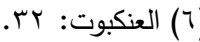

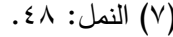
( ) الصافات: (ه) (9) الأنعام: (1) الصافات: (1) (1) (1) البقرة: (1) الانعام: 107.

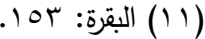
(Y) البقرة) البقرة:

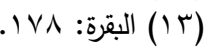




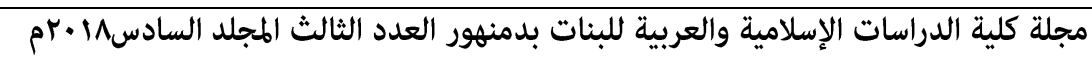

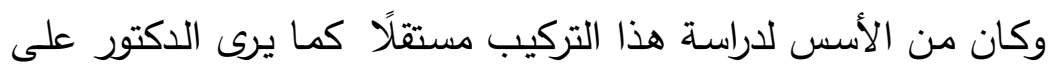
أبو المكارم التخلي عن بعض مصطلحاته الواردة في التراث النحوي من اشبه

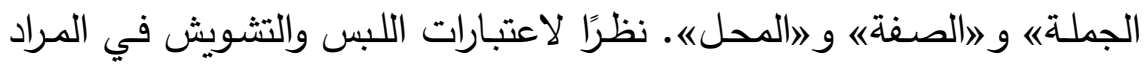

\section{مكونات الجملتّ الظرفيت كها يرصلدها النحو الحلديث:}

تتكون الجملة الظرفية من (مبتدأ وخبر) كالجملة الاسمية.

(المبتدأ) فيها هو (المسند إليه) و (الخبر) هو (المسند) فقولك عندنا

(زيد)، (زيدا) هو المسند إليه، وقولك: زيد في الدار (زيد) أيضًا هو المسند

\section{تعقيب:}

يلاحظ من مكونات الجملة الظرفية في النحو الحديث أنه اعتمد على

التراكيب اللغويـة التي احتوت على المكون شكلًا وهو قريـب بالنمـاذج التي اعتمد عليها الزمخشـري حيث استشهد في تمثيله لهذا التركيب (بخالد في الدار) ولو نظرنـا لهذه الجملـة في ظاهرهـا لوجدناها تتثـابه بالاسـية حيث احتوت عنصـرين (خالد) الذي هو مبتدأ وهو المكون الأول وهو المسند إليه و (في الدار) المكون الثاني وهو الخبر عن زيد وهو (المسند). إلى هذا الحد يتفق النحو الحديث مـع النحو في التراث حيث أخذ كل منهما بمراعاة الظاهر من خلال تحديد خصائصها اللغوية. 


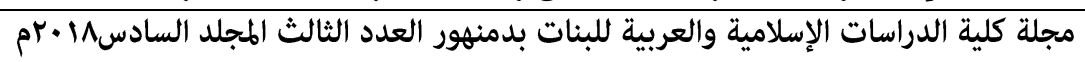

\section{أما الزركشي وابن هشاهر:}

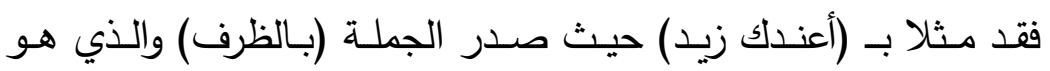

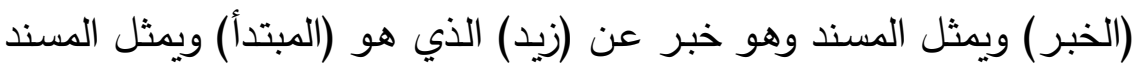

وهو أيضًا شكلًا لا يختلف عما قدمـه النحو الحديث من نمـاذج تقوم

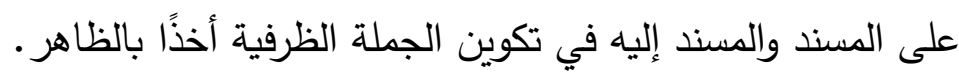

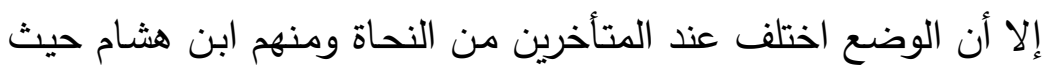

$$
\text { روعي الاتجاهات المذهبية في تعلق الظرف وعدم تعلقه. }
$$

فإذا تعلق الظرف بالفعل المقدر استقر فتكون الجملة الظرفية فعلية وزيد

فاعل لاستقر المقدر الذي تعلق به الظرف.

وإذا الظرف قد تعلق بالاسم مستقر فالجملة اسمية حينئذ.

وإذا أعرب زيد فاعل بالظرف نفسه فالجملة ظرفية حينئذ.

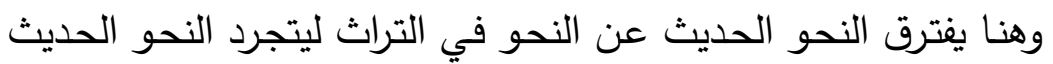

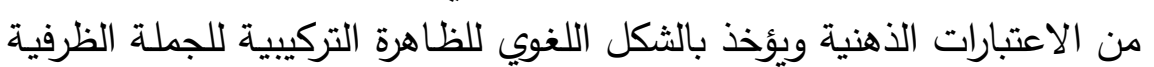

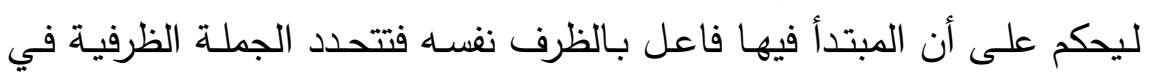

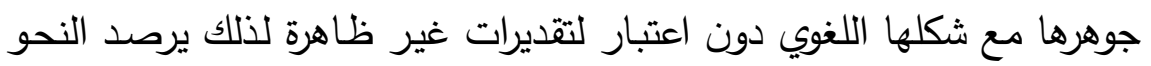

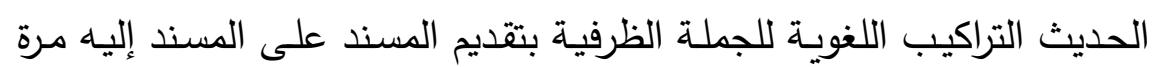

وبتقديم المسند إليه على المسند مرة أخرى. (')

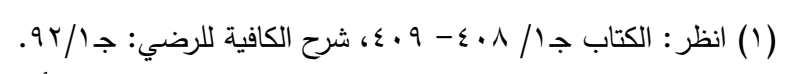

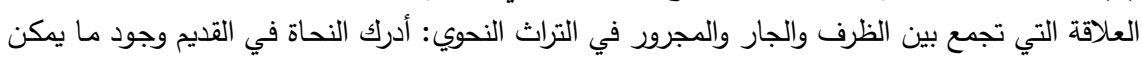

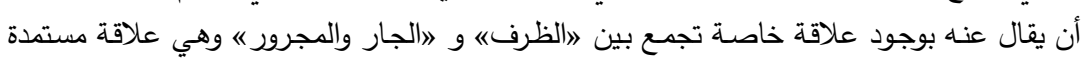

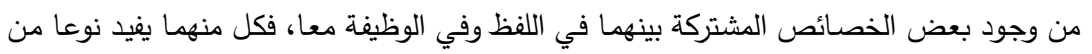

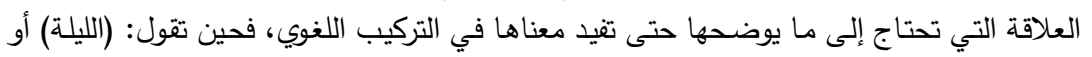

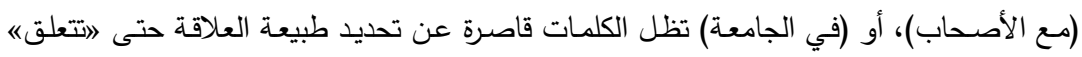

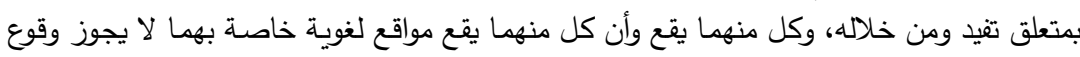

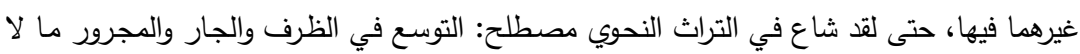

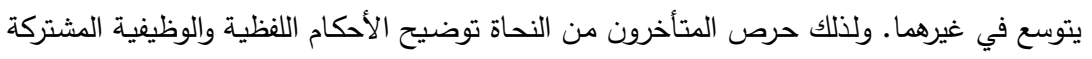

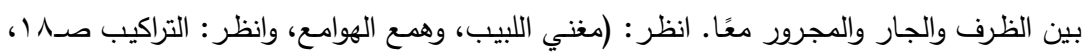


الإسناد والجملة العربيةبين القدامى والهددثين دراسة تحليلية مقارنة )

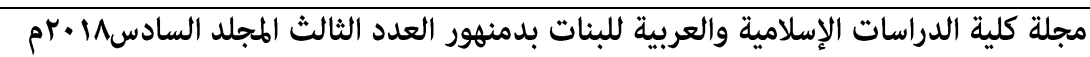

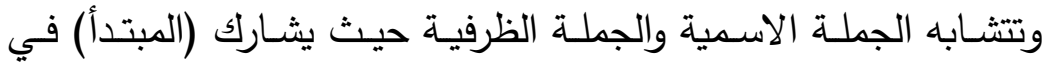

الجملة الظرفية المبتدأ في الجملة الاسمية في كثير من أنواعه وأحكامه، مثل: الاسمية، والرفع، وتعيين الدلالة، والإسناد إليه.

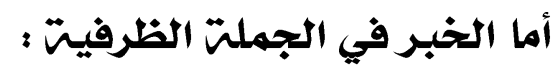

فيلزم أنه لا يكون إلا (ظرفًا) أو (جارًا ومجرورًا) غير أن جميع الظروف

ليست صالحة لوقوعها خبرا في الجملة الظرفية، كما أن حروف الجر ليست كلها صالحة لوقوعها مع مجروراتها جملة ظرفية والذي يصلح منها لذلك أنواع خاصة لابد أن تستوفي شروطا خاصة.

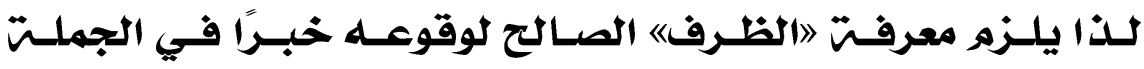

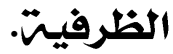

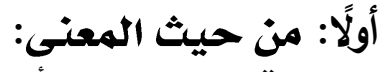

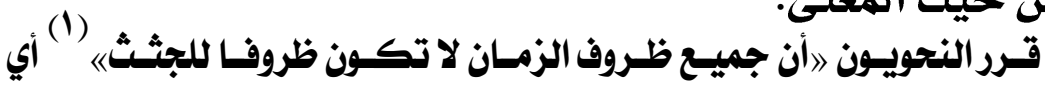

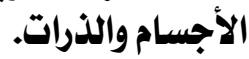

اوأن الظروف من المكان تقع للأسمائ والأفعال، فأما وقوعها للأسماي؛ فـلأن

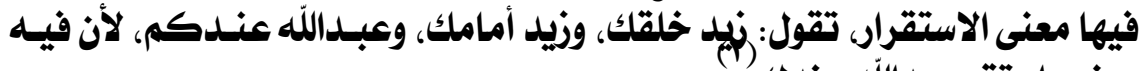

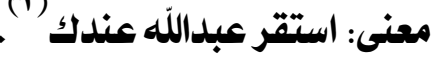

بخلاف الظروف من الزمان، فإنها لا تتضمن الجثث لأن الاستقرار فيها

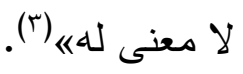

ومقتضى هذه التفرقة صلاحية (ظرف المكان) متىى اسـتوفى سـائر الشـروط

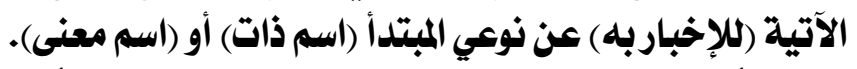

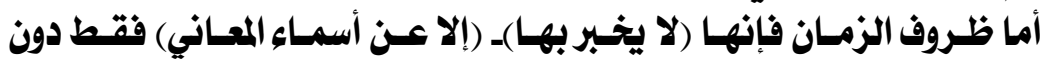

الإوات.

ومـن هنا فيصـلح أن تقول: (القتال يـوم الجمعـة) ولا تقول: (خالد يـوم

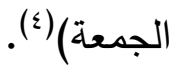

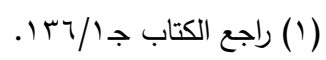

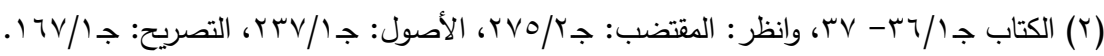

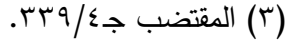

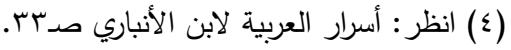


الإسناد والجملة العربيةبين القدامى والهحدثين دراسة تحليلية مقارنة )

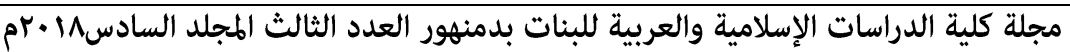
ثانيًا من حيث الدلالتّ:

قسم النحاة الظروف بهذا الاعتبار إلى قسمين أيضًا: ظروف مختصـة، وأخرى غير مختصة.

فالزمان المختص: ما دل على مقدار من الزمن معلوم نحو: اليوم الليلة- الثتاء - والصيف - والسنة- والثهر - وشهر روضـان - ويوم الجمعة.

\section{(ولا خلاف في وقوع المختص من الزمان خبرًا). أما المصكان الهختص فهو:}

مـا دل على حيز من المكان معلوم لـه اسم يدل عليه، وحدود تحيط بأبعاده مثل: المسجد والدار والطريق.

ولكن هناك من: يجيز فيها الظرفية، وأنها إذا أريد بها معنى الظرفية

$$
\text { وجب اتصالها بفي ('). }
$$

\section{أما الزمان غير المختص:}

فهو: ما دل على قدر من الزمان غير معين أي غير محدد نحو: (حين

$$
\text { - وقت- ساعة - زمان) فهذه لا تصلح جوابا لـ (متى) ولا (كم). }
$$

لذا فيـرى بعض النهـاة: أنها لا يفيد غير تأكيد الزمان الموجود في الفعل، ولذلك لا يستعمل إلا معـه، ولا ينصسب إلا بـه(r). ولا يصـلح أن يكون خبرًا فلا معنى لنحو: القتال زمانا، أو الزمان أوفى زمان لانعدام الفائدة. وأما المكان غير المختص: فهو: مـا يدل على مكان معين أو بعينه، أي اليست له حدود معلومـة تحصره، وهو يلي الاسم من أقطاره نحو: (خلف وقدام وأمام ووراء) وما أشبه ذلك، ألا ترى أنك إذا قلت: قمت خلف المسجد لم يكن لذلك الخلف نهاية تقف

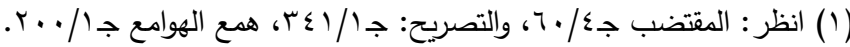

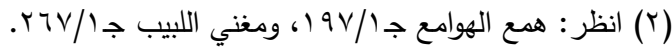


الإسناد والجملة العربيةبين القدامى والمددثين دراسة تحليلية مقارنة )

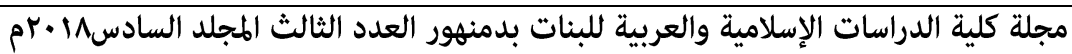

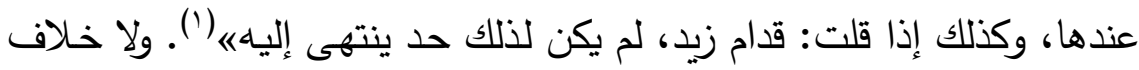
في جواز وقوعه خبرًا نحو: زيد خلفك وبيتي أمامك.

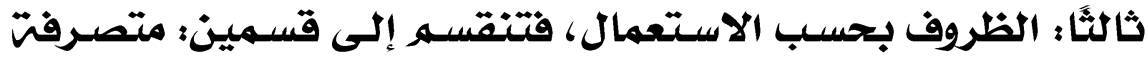
وغير متصروفت.

ولا خلاف بين النحاة في جواز استخدام الظرف (المتصرف) خبرًا سواء أكان لظرف زمان أم ظرف مكان).

أما غير المتصرف ففي وقوعه خبرًا نظر عند بعض النحاة(؟).

\section{أهما البار والمبرور}

فحروف الجر تثقسه إلى قسمين:

قسم صـالح لوقوعـه مـع مجـروره عنصـرًا إسـناديًا في الجملـة الظرفيـة مطلقة ومقيدة.

$$
\text { وقسم غير صالح لذلك. }
$$

أما القسه الأول الصالج لوقوعه خبرًا فهو: [الباء، الكاف، واللام، ومن، في حال عدم زيادتها، وإلى، وعن، وفي، وحتى] ومن بين الحروف التي تتصف بالأصالة الدائمة. وأما القسهر الثـاني الغيـر صانح ثلذيك فيضـه ما تبقى من حـروف [خلا، وعدا، وحاشا، ومذ، ومنذ، ولولا، ومتى، ولعل، والواو، والتاء].

\section{الظعاهـ السياقية لابمثلة الظرفية}

العلاقتش بين طرفي الإسناد في الجملتش الظرفيت:

يفرق النحاة بين حالتين:

الهحاثن الأولى:

يلزم فيها أن يتوافر شرطان: 


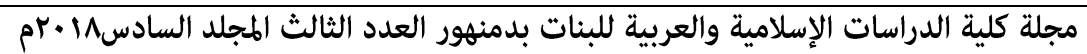
ا- أن يعتمد الظرف والجار والمجرور على نفي أو استفهام.

ץ- أن يتأخر المسند إليه عن الظرف والجار والمجرور المعتمد نحو: (ما فيها أحد)، أو (مـا في الكليـة أحد)، و(هل لديك مزيـد)، (أو هل لديك كتاب جديد) وأجاز النحاة في هذه الصورة وجهين من الإعراب:

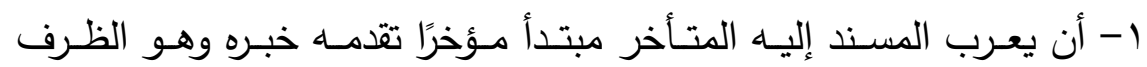

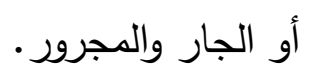

ץ- أن يكون المسـند إليـه المتأخر فـاعلا للظرف أو الجـار والمجرور نفسـه، أو لمتعلقهما المحذوف.

ومن هنا رأى بعض النحاة إمكان جعل (هذه الصـورة) ضـن الجملـة الاسمية إذا أخذنا بالإعراب الأول. وإمكان جعلها ضدن الجملة الفعلية إذا أخذنا بالإعراب الثاني اعتمـادًا على أن الظرف والجار والمجرور فيها قد عمل عمل الفعل بنفسـ أو لنيابته عن الفعل حيث رفع المسند إليه على الفاعلية(1). الحاثن الثانين: لا يتوفر هذا الشرطان معا، ولعدم توافرهما صور ثلاث: فقد ينتفي أحد الشرطين، كما قد ينتفيان معا. فمن انتفاء الثرط الأول وحده: وهو فقد الاعتماد على نفي أو استفهام،

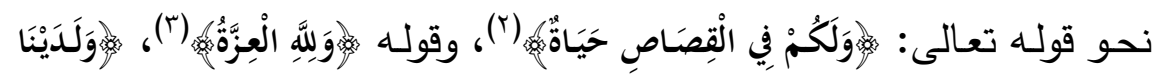

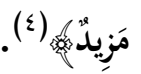

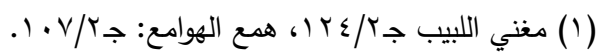

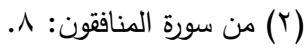

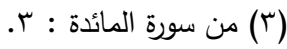

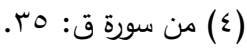




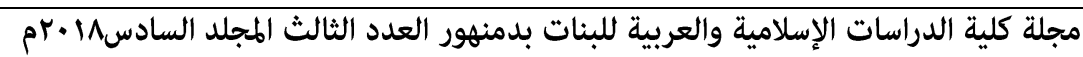

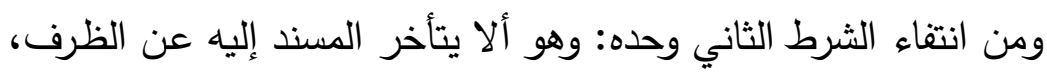

$$
\text { قولك: هل المدرس عندك، وما الأب في الدار . }
$$

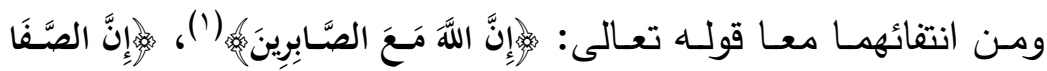

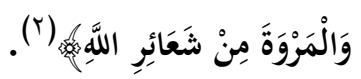

ويعرب النحـاة الجملـة (مبتدأ وخبـر) ويرفضـون أن يعرب المسـند إليـه

$$
\text { • «اعَاًِ }
$$

وأجاز البعض فيما إذا انتفى الثرط الأول وحده وهو الاعتماد دون غيره

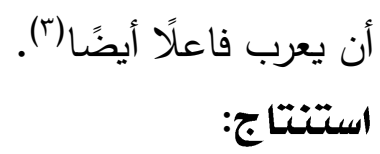

يستتج أن التراث النحوي يجعل للظرف والجار والمجرور الواقعين ركنا

$$
\text { إسناديا في الجملة أحولًا وأحكامًا متعددة. }
$$

إلا أن مـن الممكن الخلاصـة إلى حقيقـة واضـحة وهـي: جـواز إعراب »الظرف《 و \الجار والمجرور 《 في كل الحالات خبرًا تقدم أو تأخر ، اعتمد أو لم يعتمد. إذ يقول الرضي: ״يجوز أن يقال في جميع ذلك: إن الظرف خبر «(ء).

وإلى هذا الرأي لجأ الدكتور على أبو المكارم من المحدثين حيث قطع

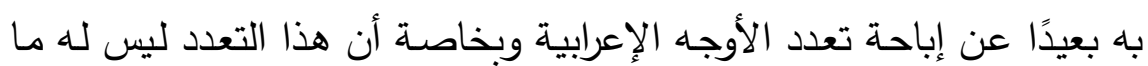
يبرره من الخصائص الأسلوبية(أن). أما الضوابط التي تحكم العلاقة بين طرفي الإسناد في الجملة الظرفية تتشـابه في مجموعها بالضـوابط التي تحكم علاقـة ركني الإسـناد في الجملـة 


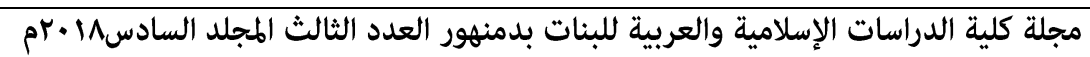

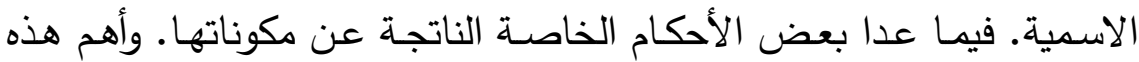

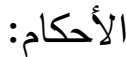

\section{أما من حيث التطابق العلددي:}

لا تطابق في الجملة الظرفية باتفاق النحاة إذ أن العنصر الإسنادي -

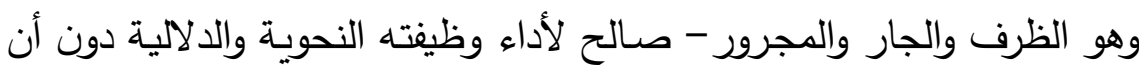
يتأثر بنوع المسند إليه أو عدده فيقال:

التلميذ في الكلية، أو التلميذان، أو التلاميذ، أو التلميذة أو التلميذتان، أو التلميذات، كل ذلك دون أن يترك تتوع المسند إليه في الجملة أثرا في شكل المسند فيها ومثله أيضًا.

التلميذ عند زيد أو التلميذان أو التلاميذ أو التلميذات. ومن أمثلة ذلك

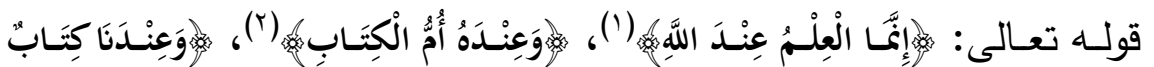

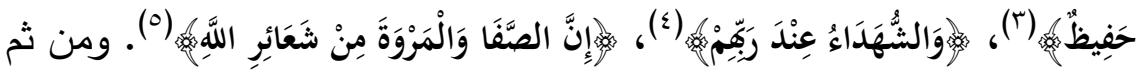
تختلف الجملة الظرفية مع الاسمية في التطابق. أما الترتيب بين طرفي الإسناد في الجملث الظرفيت: فتتشابه الجملة الظرفية بالاسمية في أحوال الترتيب.

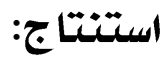

يستنتج من خلال عرض الجملة الظرفية عند نحاة العصر الحديث إلى وجود ثمة تشابه بين النحو في التراث والنحو في العصر الحديث حيث تمثل التشابه في:

$$
\begin{aligned}
& \text { (1) من سورة الأحقاف: بr (1) }
\end{aligned}
$$

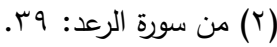

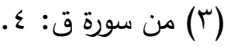

$$
\begin{aligned}
& \text { (ع) من سورة الحديد: } 19 . \\
& \text { (0) من سورة البقرة: } 101 .
\end{aligned}
$$




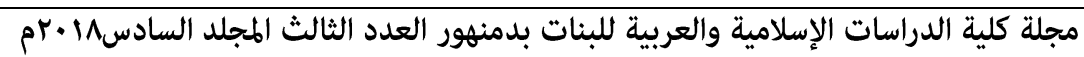
ا- أن الجملة الظرفية اختصت بخصائص من جهة التطابق والترتيب والتقييد والامتداد والبساطة والتركيب.

ورد ذلك من خلال رصد النحاة للتراث اللغوي من جهة ومن جهة أخرى ولاث تتاول نحاة العصـر الحديث التراكيب بالتحليل للظاهرة وإبراز هذه المقومـات وتلك الخصائص المميزة للجملة مما يجعلها كيانا مستقلا تركيبًا مستقلًا من بـن تراكيب الجملة الإسنادية. r- استخدام مصطلح الجملة الظرفية لدى كل منهما.

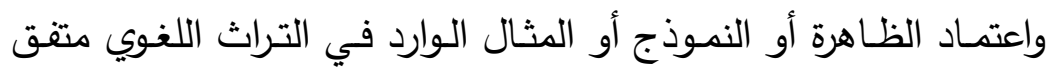
عليه تركيبا إسناديا عند كل منهما.

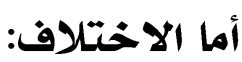
فيرجع إلى توجيه دائرة البحث عند كل منهما، فدائرة البحث عند نحاة التراث النحوي ترجع إلى اعتبارات مذهبية وملاحظات لغويـة. بينما مـع نحاة العصر الحديث ترجـع الاعتبارات إلى تحليل التركيب وإبراز خصائصسه ومقوماته التي تميزه عن غيره من الجمل الإسنادية الأخرى مـا أراه امتداد لدائرة البحث الذي بدأها نحساة التراث والتي يرجع إليهم فضل

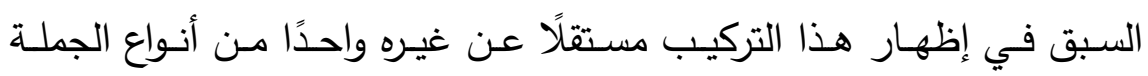
الإسنادية. 


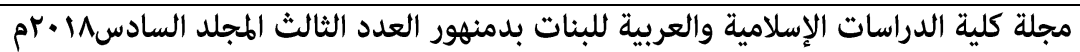

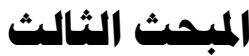

\section{أثزوه في التزكيسب البوصفي}

يطلق مصطلح الجملة الوصفية في كتب التراث ويعنى بها: الوصف في بالجملة أي الجمل التي تقع وصفا نحو قوله تعالى :

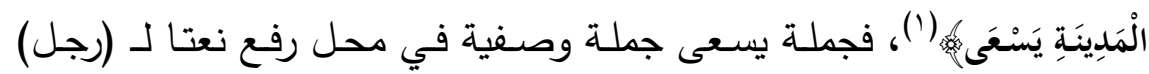
ورجل فاعل فكانـت الجملة تابعـة لما لـه محل من الإعراب. لأن الجمل بعد النكرات صفات.

إلا أنه ذاع في العصـر الحديث مصطلح (الجملة الوصـفية) وكان لـه اعتبار آخر بالإضافة إلى هذا الاعتبار القديم.

وهذا الاعتبار الجديد: يخص تركيب آخر خلاف ما سبق بل هو نوع معين من أنواع الجمل الإسنادية، يختلف في مقوماته وعلاقته عن بقية أنواع الجملـة العربية. وهو استخدام حديث نشأ في رحاب المحاولات النحويـة التي ينهض بها بعض الباحثين المجتهدين من نحاة العصر الحديث. وتدل الجملة الوصفية عندهم على:

الجملة التي تتكون من وصف (اسم فاعل، أو صفة مشبهة، أو صيغة مبالغـة، أو اسـم مفعول) + اسـم مرفـوع، أو ضـمير شخصـي منفصـل للرفـع. مثل: (أناجِح أخوالك)، (ما حاضرٌ أنتم)، (ما محبوبُ الخائنون). فالرفع كمـا تلاحظ في (أخـواك) و(أنتح) على الفاعليـة لأن الرفح في (الخائنون) على النيابـة عن الفاعل حيث إن الوصف محبوب اسم المفعول فيعمل عمل الفعل المبني للمجهول لأنه مصوغ من المبني للمجهول.

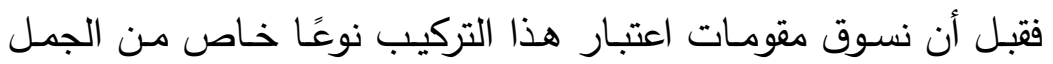
الإسنادية في النحو الحديث يلزم الإشـارة إلى مكانه هذا التركيب من الجمل الإسنادية في التراث النحوي. 


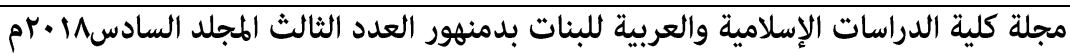
حيث نرى أنه كان يعد ويصنف من قبيل الجملة الاسمية، إذ أن الجملة الاسمية في التراث النحوي تتعت بصدرها وصدر هذه التراكيب (أسماء) فلذلك اعتبر النحاة القدامى تصنيفه من قبيل الجملة الاسمية.

على أنه:

اختلف حوله النحاة القدامى بين بصرين وكوفيين حيث وقع الوصف الوف مبتدأ بـه صدر الجملة الاسمية وكان حق ما بعده الرفع ولأن الوصف يعمل

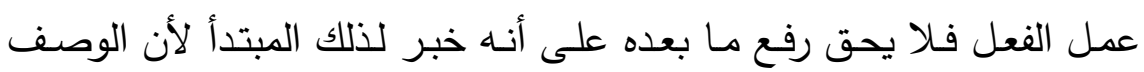
يحتاج فاعلًا ولا يحتاج خبرًا لذلك. اعربه البصريون: فاعلً شريطة اعتماده على ما يقرب الوصف ويدعمـه شبهه بالفعل من نحو أدوات الاستفهام أو ما يثـابهها من نفي لذلك، ونحوه،

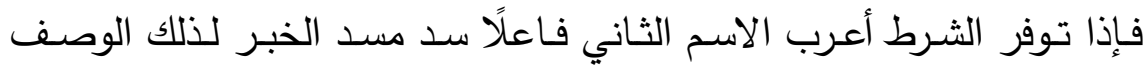
المتصدر وعلى هذا الاعتبار كان (أخواك) في نحو: أقائم أخواك، فاعلًا سد

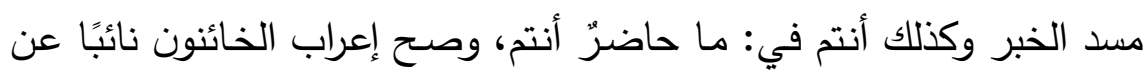
الفاعل في قولك: ما محبوب الخائنون. لذلك رأينا ابن يعيش يقول:

اواعلم أن قولهم: (أقائم الزيدان) إنما أفاد نظرًا إلى المعنى، إذ المعنى: أيقوم الزيدان؟ فتم الكلام؛ لأنـه فعل وفاعل، و(قائم) هنا اسم من جهة اللفظ وفعل من جهة المعنى، أراد إصـلاح اللفظ، فقالوا: أقائم مبتدأ، والزيدان مرتفع 


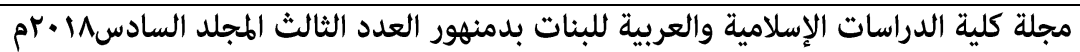

\section{والعلتم في ذلك:}

أنها لمـا دخل عليها معنى يناسـب الفعل كمعنى النفي أو الاسـتفهام أو الـلام الموصـولة؛ كان لابـد من تقديرها فعـلا، فترفع مـا بعدها مـن الاسـم

الظاهر ؛ وتلزم حينئذ الصدر فتعرب (مبتذأ)، ولا شيء غير ذلك(').

وقيل: الاعتماد شرط في الاكتقاء بالمرفوع عن الخبر •

أما الكوفيون:

فعندهم يعمل الوصف الرفع فيما بعده سواء اعتمد على نفي أو استفهام

وما شابهه أو لم يعتمد(r).

وسواء على هذا المذهب أو ذاك فالنحاة يعدون مثل هذا التركيب من

الجمل تركيب اسمي كما ترى باعتبار تصدره للجملة والعبرة في التراث النحوي

بما تصدر

أما في النهو الكحديث:

فمقومات اعتبار هذه الجملة نوعا مستقلا من الجملة العربية- عند هؤلاء

المحدثين أمران أساسيان:

أولهمـا: اعتبـار (الوصفف) نوعًا مستقلًا مـن أنواع الكلمـة العربية أخذًا

بالاعتبارات التي ذكرهـا الدكتور تمـام حسـان في كتابـه اللغـة العربيـة معناهـا ومبناها(). وهي الاعتبارات التي بنى عليها حماستة القول بالتركيب الوصفي حيث عده الصنف الثالث والأخير من الجمل التامة الإسنادية في تقسيم الجملة العربية.

إذ يقول مهاجما النحاة في إعدادهم مثل هذا النوع من التراكيب الاسمية:

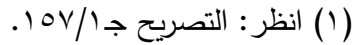

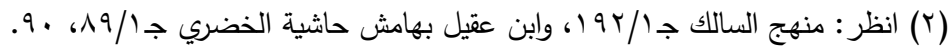

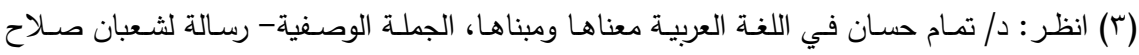

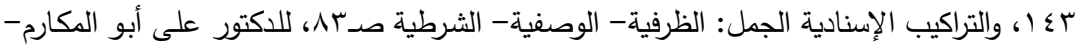

مؤسسة المختار للنشر والتوزيع القاهرة. 


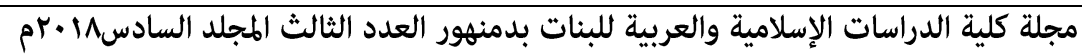

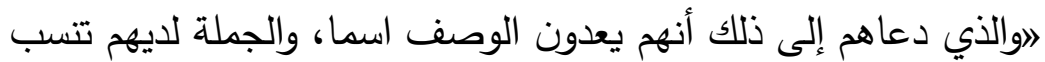
إلى صدرها، ولذلك لم يجدوا بأسًا في أن تكون هذه الجملة مـع كونها مزيجا متنافرًا من الوظائف جملة اسمية، فإذا ثبت أن الوصف مختلف عن الاسم في الخصائص والصفات، وأنه قسم مستقل من أقسام الكلم لأنها لا يدل على ما يدل عليه الاسم، وأن الجملة تنسب إلى صدرها، فإننا يمكنتا أن نعد هذا النوع جملة متميزة عن بقية أنواع الجمله(').

وليست هذه جملتش اسميته، لأن الجملة الاسمية يتطابق فيها المبتدأ والخبر في مثل: المحمدان ناجحسان - المحمدون نـاجحون، أمـا في الجملـة الوصـفية فـلا يكون ثــة تطـابق مـن هذه الناحيـة فنقول: أنـاجح المحمـدان،

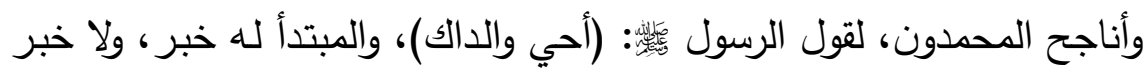
للوصف المذكور شدة شبهه بالفعل على حد تعبير ابن مالك(r). وهذه الجملة لا تدخل عليها النواسخ التي تفيد التوكيد والتمني والترجي والاستدراك والتثبيه، أي (إن وأخواتها) ولا تقبل من النواسخ الأخرى إلا (ليس)

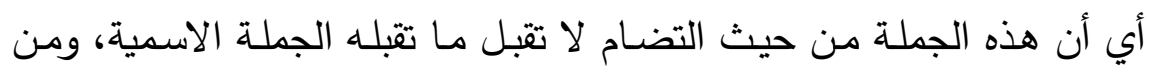

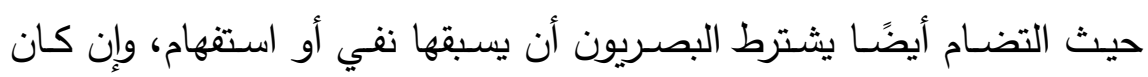
الكوفيون وابن مالك لا يشترطون هذا الشرط. والجملة الاسمية لا يوجد فيها مثل هذا الخلاف. والرتبة في هذه الجملة ملتزمة بين الوصف وفاعله، فلا يتقدم مرفوعـا على الوصف، وإلا لم تعد جملة وصفية، وصارت جملة اسمية، ولا تتم هذه الصورة إلا إذا كانت هنالك مطابقة في العدد. فالمطابقة في هذه الجملة ملتزمـة في النوع (التذكير والتأنيث) وأما من هن

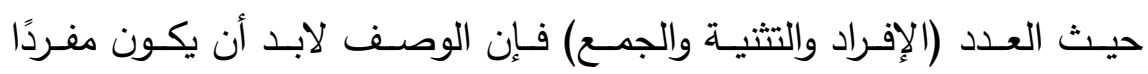




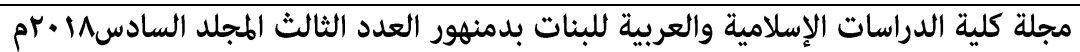

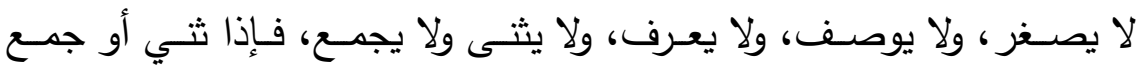
فلا تكون الجملة وصفية وتكون حينئذ جملـة اسمية تقدم فيها الخبر ، وتأخر المبتدأ كقول الرسول

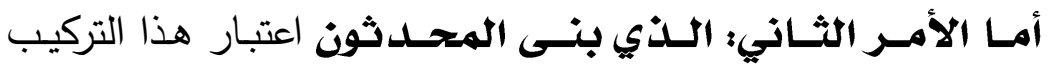
الوصفي مستقلً بنفسه لا يعد تركيبا اسميًا: الالرغبـة في الـتخلص مدـا يمكـن وصـفه بازدواجيـة التحليـل، وهـي الازدواجية التي قد يسلم إليها الأخذ بالاتجاه الثـائع في التراث النحوي في تحليل هذه الجملة، الأمر الذي يوهم أن الجملة مكونة من مسندين إليهما، دون وجود الطرف الإسنادي الثاني وهو المسند- فيها《(r). لذا فيرى هؤلاء الباحثون المحدثون مقومـات إعداد مثل هذه التراكيب صاحبة المكونات المنفردة والمتميزة عن التراكيب الاسمية- دافعًا قويـا لإعداده تركيبا وصفيًا مستقلًا. وعندهر:

يكفي في إعراب الوصف أن نقول عنـه إنـه وصـف فاعل مرفوع أو وصف مفعول مرفوع أو وصف مبالغة مرفوع إلى آخره، دون أن نشير إلى أنه

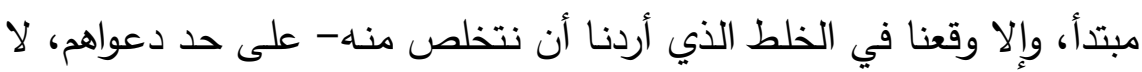
يخرج الوصف في الجملة الوصفية عن هذا الإعراب، إلا إذا أضيفت إليه كلمة (غير) في مثل قول الشاعر :

غير لاهٍ عداط فاطرح اللهو ... ولا تعتر بعارض سله (ع)

(1) انظر : شواهد التوضيح والتصـيح لمشكلات الجامع الصحيح صـء - لابن مالك. وراجع: صحيح

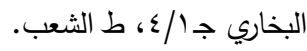

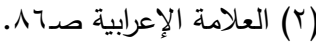

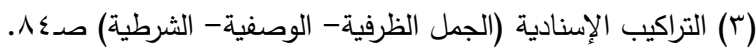

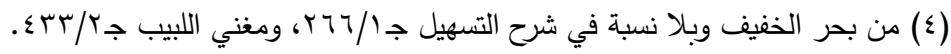




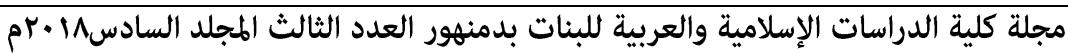

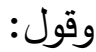

\section{غير مأسوفٍ على زمن ... ينقضي بالهه والحزن (')} فيجر بالإضـافة، أو إذا دخلت على ؤنى الجملـة (ليس) مثلـ: (ليس قائم

الوصـف مـع مرفوعـه، ولـو ظـاهرًا في قوة المفـرد؛ فـالرد عنـــــــؤلاء

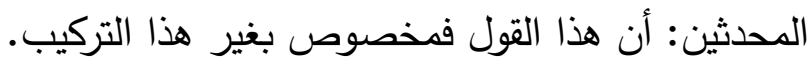
على حد اعتمادهم في هذا على تعبير الخضري في حاشيته على شرح

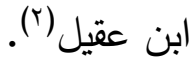

وبهذا تستقيم الجملـة الوصفية جملـة عند هؤلاء مكتملـة الخصـائص،

$$
\text { منفردة عما سواها("). }
$$

\section{مكونات الجملت الوصفيت:}

تتكون هذه الجملة من عنصريين إسناديين هما: (المبتدأ) وهو (المسند)

$$
\text { في الجملة- و(المرفوع) بعده وهو المسند إليه فيها. }
$$

ويتميز هذا المبتدأ: بأن لا يكون إلا اسما حقيقيا صريحا ظاهرًا وصفًا

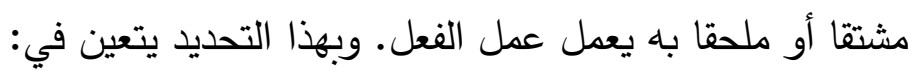

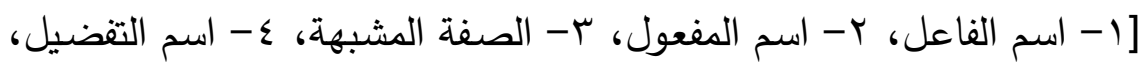

$$
\text { ه- المنسوب]. }
$$

$$
\text { ويمكن أن يضاف صيخ المبالغة على خلاف فيها بين النحاة(£). }
$$

(1) قائله: أبو نواس من بحر المديد. ينظر : أمالي ابن الحاجب صدمبآ، دراسة وتحقيق فخر سليمان

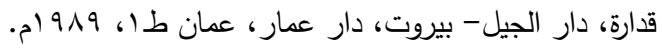

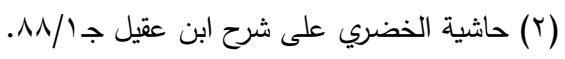

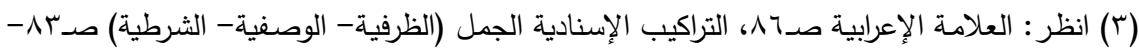

(ء) لـم يتبقـى بعد ذلك ممـا يعمـل عمل الفعل في التراث النحـوي إلا (المصدر واسمـه، واسـم الفعل، 


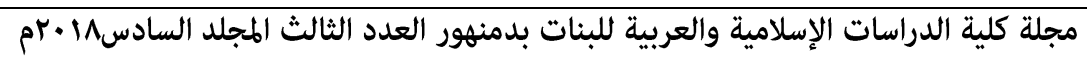

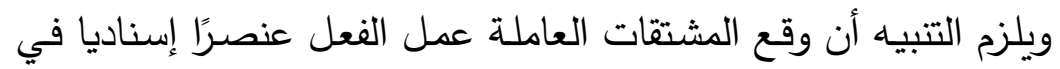
الجملة الوصفية مشروط بشروط.

فإذا لم تستوف الشروط؛ فإنها لم تصبح صالحة للوقوع طرفا إسناديا في الجملـة الوصـفية. بـل مـن الممكن أن تقـح عنصـرًا إسـناديا في غيـر الجملـة الوصـفية مـن جملـة: (اسـية، أو ظرفيـة، أو فعليـة) وذلك إذا قلـت (العامـل محترم) و (في القلب منا العامل بإخلاص) و(يحترم العامل الجاد عمله) حيث وقع اسم الفاعل في الأمثلة مجرد نموذج يمكن أن يقاس عليه بقية المشتقات ومـا ألحق بها مـن المنسوب فمـا هو (اسـم الفاعل) إلا مسـنًا إليـه في غيـر الجملة الوصفية(') - (1)

\section{أما المسند إليه في هذه الجملش فله أحسار تميزه:}

ا - فلا يكون مفردًا أي يجب أن يكون مثنى أو مجموعًا. r- هو مرفوع دائما بالمسند، فلا يقع غير مرفوع.

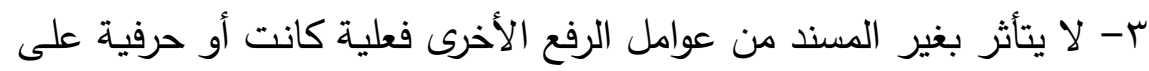
الرأي الذي يجعل للحروف عمل. ع - واجب الذكر في الجملة.

0- ملتزم الوجود بعد المسند فيها.

مقتضى هذه الأحكام أنه لا يقبل الإفراد ولا النسخ ولا الحذف، ولا التقدم(؟).

والظرف، والجار والمجرور) وإنما لم تدخل هذه الخمسة ضمن (المبتدأ) في العنصر الإسنادي الأول

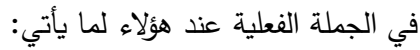

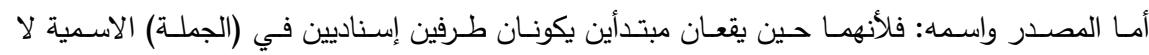

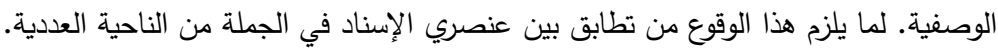

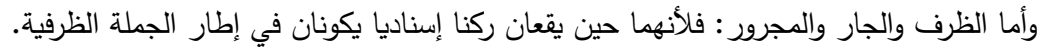
وأما اسم الفعل: فلأنه شأنه شأن الفعل - يقع ركنا إسناديا دائما في الجملة الفئ الفعلية.

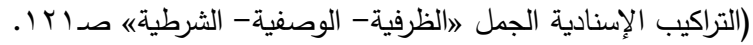

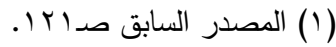
(Y) أما أنـه لا يقبل الإفراد، فلأنها إذا وقع مفردًا تحولت الجملة حينئذ إلى جملة اسمية؛ لتحقق التطابق $=$ 
الإسناد والجملة العربيةبين القدامى والهددثين دراسة تحليلية مقارنة )

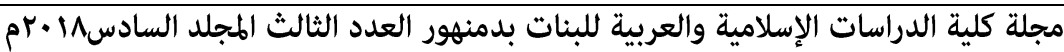

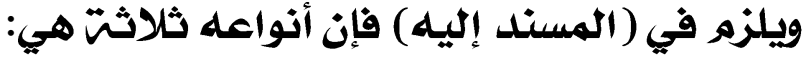
1- أن يكون اسما جامدًا. r- r أو أن يكون اسما مشتقًا.

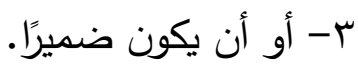

وتقدم هذه الأنواع الثلاثة ستة احتمالات؛ لأن كلا منهما يمكن أن يكون مثنى، كما يمكن أن يكون جمعا. أما السياق: فله احتمالات ثلاثة: أن يكون إيجابا، أو نفيا، أو استفهاما.

أما المحكملات:

فدورها في تعدد النماذج النمطية للجملة الوصفية من دخول واحد منها

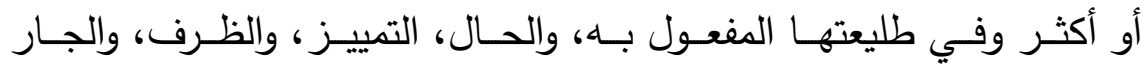
والمجرور ، والتوابع الأربعة: النعت- والعطف- والتوكيد - والبدل.

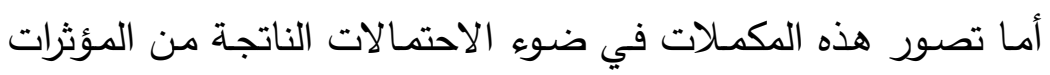

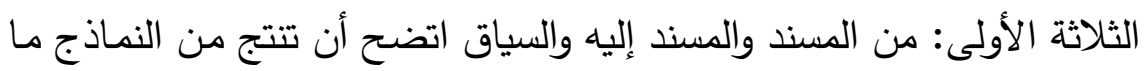

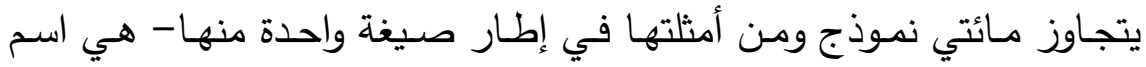
الفاعل على النحو الآتي ('):

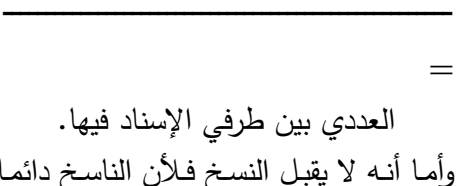

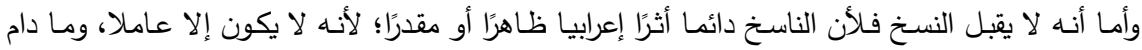

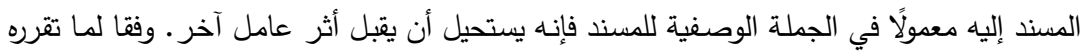
الأصول من عدم اجتماع عاملين على معمول واحد.

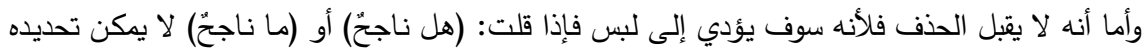

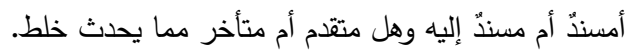

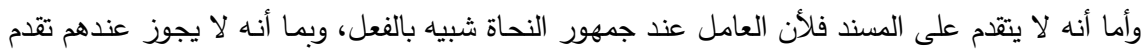

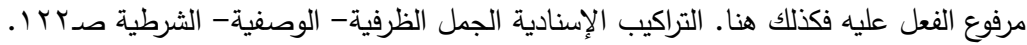

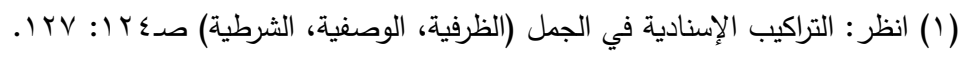




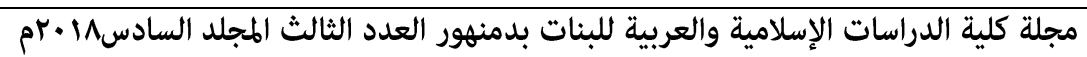

أولًا: اسـم فاعـل مقترن بـ (أل) الموصـولة + اسـم جامـد مثنى، مثل:

$$
\text { الصامت أخوالك. }
$$

اسم فاعل مقترن بـ (أل) الموصـولة + اسـ جامد جمع مثل: الصـامد

اسم فاعل مقترن بـ (أل) الموصولة + اسم مشتق مثنى. مثل: الحاضر صديقاك.

اسم فاعل مقترن بـ (أل) الموصولة + اسم مشتق جمع، مثل: الجالس

اسـم فاعـل مقتـرن بـ (أل) الموصـولة + ضـمير مثنى منفصـل، مثل:

$$
\text { المتعدي أنتما. }
$$

اسـم فاعل مقتـرن بـ (أل) الموصـولة + ضــير جــع منفصـل، مثل :

$$
\text { الفاهم أنتم. }
$$

ثانيّا : أداة نفي + اسم فاعل مقترن بـ (أل) الموصـولة + اسـ جامـ

$$
\text { مثنى، مثل: ما الصمت أخواك. }
$$

أداة نفي + اسم فاعل مقترن بـ (أل) الموصولة + اسم جامد جمع، مثل:

$$
\text { ما المستكين رجالنا. }
$$

أداة نفي + اسـ فاعل مقترن بـ (أل) الموصـولة + اسـ مشتق مثنى،

$$
\text { مثل: ما الحاضر صديقاك. }
$$

أداة نفـي + اسـم فاعل مقترن بـ (أل) الموصـولة + اسـم مشـتق جمعح،

$$
\text { مثل: ما المتحدث مريدوك. }
$$

أداة نفي + اسم فاعل مقترن بـ (أل) الموصولة + ضمير مثنى منفصل، 


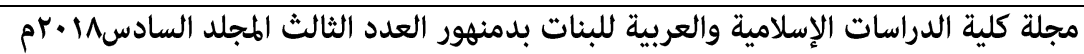

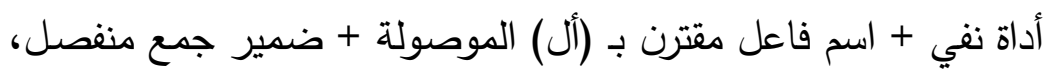
مثل: ما المعتدي أنتم (1).

ثالثًا: أداة استفهام + اسم فاعل مقترن بـ (أل) الموصولة + اسم جامد

$$
\text { مثثى، مثل: هل الصامت أخواك؟ }
$$

أداة استفهام + اسم فاعل مقترن بـ (أل) الموصولة + اسم جامد جمع،

$$
\text { مثل: هل الصامد رجالنا؟ }
$$

أداة استفهام + اسم فاعل مقترن بـ (أل) الموصولة + اسم مشتق مثنى،

$$
\text { مثل: هل الحاضر صديقاك؟ }
$$

أداة استفهام + اسم فاعل مقترن بـ (أل) الموصولة + اسم مشتق جمع،

$$
\text { مثل: هل الجالس مريدوك؟ }
$$

أداة اسـتفهام + اســم فاعـل مقتـرن بـ (أل) الموصـولة + ضــير مثنى

منفصل، مثل: هل المهاجم أنتما؟

أداة اسـتفهام + اســم فاعـل مقتـرن بـ (أل) الموصـولة + ضــمير جمـع

$$
\text { منفصل، مثل: هل المعتدي أنتم؟ }
$$

رابعًا: اسم فاعل مجرد من (أل) اسم جامد مثنى، مثل: صامد أخواك.

اسم فاعل مجرد من (أل) اسم جامد جمع، مثل: مناضل رجالنا.

اسم فاعل مجرد من (أل) اسم مشتق مثنى، مثل: مقاتل زميلانا.

اسم فاعل مجرد من (أل) اسم مشتق جمع، مثل: ثائر أحباننا.

اسم فاعل مجرد من (أل) ضمير مثنى منفصل، مثل: مسافر أنتما.

اسم فاعل مجرد من (أل) ضمير جمع، مثل: متخلف أنتم.

خامستّا: أداة نفي + اسـم فاعل مجرد + اسـم جامد مثنى، مثل: مـا

$$
\text { صامت أخواك. }
$$

أداة نفي + اسم فاعل مجرد + اسم جامد جمع، مثل: ما حاضر رجالك. 


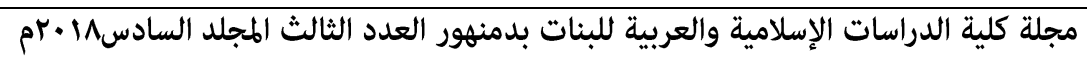

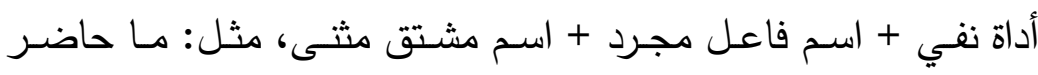
صديقاك.

أداة نفـي + اسـم فاعـل مجـرد + اسـم مشـتق جــع، مثل: مـا جـالس محبوك.

أداة نفي + اسم فاعل مجرد + ضـمير مثنى منفصل، مثل: مـا معتد

أداة نفي + اسم فاعل مجرد + ضـير جمع منفصل، مثل: مـا مهاجم

سادسًاً: أداة استقهام + اسم فاعل مجرد + اسم جامد مثنى، مثل: هل صامت أخوالك.

أداة استفهام + اسم فاعل مجرد + اسـم جامد جمع، مثل: هل صـامد رجالنا.

أداة استفهام + اسم فاعل مجرد + اسم مشتق مبني، مثل: هل حاضر صديقاك.

أداة استفهام + اسـم فاعل مجرد + اسـم مثنى جمع، مثل: هل جالس

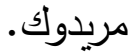

أداة اسـتفهام + اسـم فاعل مجـرد + ضـمير مثنـى منفصـل، مثل: هل مهاجم أنتما.

أداة استفهام + اسم فاعل مجرد + ضمير جمع منفصل، مثل: هل معتد 


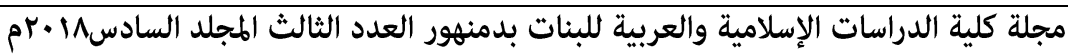

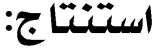

يستنتج الآتي: - n

- توافق نحاة القديم والحديث في إطلاق لفظ اجملة) على هذا التركيب. ثم اختلافهما في المتبع لـه فالقديم على أنسه جملة اسمية والحديث على أنـه جملة وصفية.

- اعتماد النماذج الواردة في الواقع اللغوي متفق عليه فيما بينهم. - اسـتحداث مســى التركيـب (الجملـة الوصـفية) يرجـع إلـى نحـاة العصـر الحديث.

- اعتباره تركيبا مستقلا عن الجملة الاسـية لانفراده بخصـائص تميزه عنها يرجع إلى نحاة العصر الحديث.

- التوافق على انفرادية هذا التركيب بما يميزه بصرف النظر عن المسمى. - يرى البحث ترجيح التقسيم الموروث في النحو العربي من إدراج هذا النموذج من التراكيب تحت مسمى الجملة 》الاسميةه نظرًا إلى مكوناته فهي من البداية إلى النهاية (مبتدأ) و(خبر) وهذه وتلك مكونات الجملة الاسمية فلا مفر من إدراجـه تحت الاسمية فأين الجديد في كلام النحو الحديث إلا فرارًا من النمط القديم. 


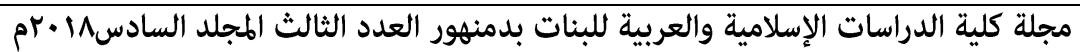

\section{الخاتمهة لتهن}

\section{أهمر النتائج والتوصيات}

1-(اللغة أصـوات يعبر بها كل قوم عن أغراضهـم) خلاصـة تعريفات القدامى لها وعلى الأخص ابن جني، فهي إذن أصسوات منطوقة، مما يفسر لنا أن النحاة الأوائل عرفوا اللغة سماعًا قبل رؤيتها رموزًا مصورة، ومن ثم يتبين لنا اهتمامهم بالروايـة والسماع والمشافهة في جمـع اللغـة وكذلك اهتمـامهم بعلم القراءات وعلم التجويد.

ץ- لزوم الترابط بين اللغة والجمل أو الكلام إذ أن العلاقة بينهما وطيدة فالكلام

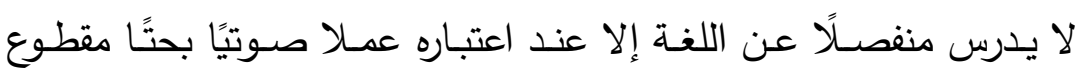
الصلة بالمعنى. فإن الدراسة اللغوية للكلام تجعله حتى على هذا المستوى لإلى الصوتي على صلة باللغة. "ا أن اللغة مجموعة من الأنظمـة والعلاقات، بينما (الجمل) أو (الكلام) هو

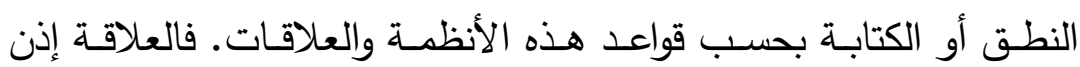
بينهمـا تبـدو لزوميـة إذ أن اللغــة تتمثـل فـي النظـام الصــوتي، والنظــام الصرفي، والنظام النحوي، مما يلزم عند صوغ الجمل أو العبارات والكلام أن ينطق، أو يكتب بحسب قواعد هذه الأنظمة والعلاقات.

(اللغة) و(الجمل) لكل منهما لله طابع خاص. فالكلام أو الجمل عمل، واللغة حدود هذا العمل، الكلام سلوك أما اللغة فمعايير هذا السلوك، والكلام نشاط واللغة قواعد هذا النشاط والكلام حركة، واللغة نظام هذه الحركة، والكلام يحس بالسمع نطقًا والبصر كتابة، واللغة تفهم بالتأمل في الكلام. فالذي نقوله

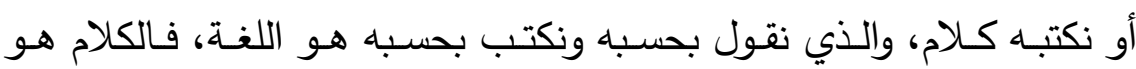
المنطوق وهو المكتوب، واللغـة هـي الموصسوفة في كتب القواعد وفقـه اللغـة والمعجم ونحوها والكلام قد يحدث أن يكون عملًَ فرديا، ولكن اللغة لا تكون 


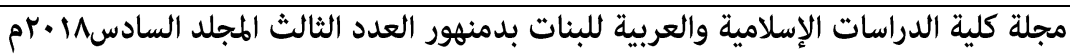
إذن اللغة بالنسبة للمتكلم معايير تراعى، وبالنسبة للباحث ظواهر تلاحظ وهي النسبة للمتكلم ميدان حركة، وبالنسبة للباحث موضوع دراسة وهي بالنسبة للمتكلم وسيلة حياة في المجتمع، وبالنسبة للباحث وسيلة كثف عن المجتمـ. وهو ما أشار إليه سيبويـه النحو في العصر الحديث الدكتور تمام حسان. ك-يختلف النحاة العرب في تحديد: (علاقة الكلام بالجملة) ليصلو إلى وجود فريقين الأول منههـا: على أن الكلام يرادف الجملة وفي مقدمـة هؤلاء ابن جني الذي جاء تعريفه غاية في الدقة والفهم وانتصر لـه بعض النحاة الدارسين المحدثين ومنهم الدكتور حمد حماسة عبداللطيف. وكذلك أمثلته، لأنه بهذا التعريف يتيح الفرصـة لدراسـة أنماط التراكيب المختلفة، واعتبار كل تركيب مستقل بنفسـه مفيد لمعناه 》جملة| في صورتها التي قيلت بها.

ويعد توسعه هذا بإعطاء متعددة 》للجملة) يعبر عن بصيرة ناقدة في

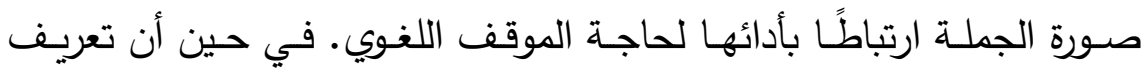
الزمخشري لم يحظ بالتوسـع والدقة التي حظي وظفر بها تعريـف ابن جني، وربما لخص كل مـا أتى بـه ابن جني في عبارته بدون توسـع عندما حصر تعريفـه للجملـة في صـورتين اثنين بقوله: الكـلام: (هو المركب مـن كلمتين أسـندت إحـداهما إلىى الأخـرى) مـع الأخذ في الاعتبـار بـأن الكـلام والجملـة مترادفان

أمـا الفريـق الآخــر: فيرى الفصـل بينهمـا على نحـو مـا ذهب إليـه الرضـي وابـن هشـام والسيوطي. فالجملـة عندهم أعم مـن الكـلام إذ أن الكـلام عندهم (القول المفيد بالقصد) فشرطه الإفادة بينمـا الجملة عبارة عن (الفعل وفاعله أو المبتدأ وخبره) والكقيقن أن ما ذكره ابن هشام هو ما جرت عليه كتب النحو المتأخرة، فيعرفون الكلام في صدر كتبهم، وننعتونه بالإفادة، وحين يتحدثون عن الجمل التي لها محل من الإعراب والجمل التي لا محل لها من الإعراب يقولون: جملة الصلة وجملة الشرط وجملة الجواب وهكذا. 


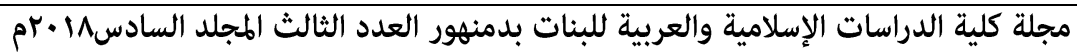
وقد فسر السيوطي موقف النحاة هذا بقوله: أن إطلاق (الجملة) على ما ذكر من الواقعة شرطًا أو جوابا أو صلة فإطلاق مجازي ولا يسمونه كلامًا لأن كل ذلك ليس مفيدًا فليس بكلام. بخلاف الجملة عندهم إذ يرونها وخاصة ابن هشم تركيب إسنادي فعلي

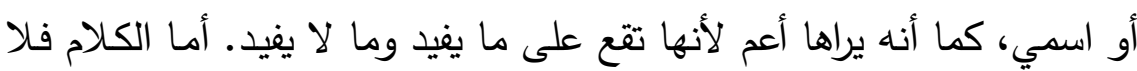
يوضع إلا فيما يفيد.

○ـ أن تميز الجملة من الكلام عند من قال بالفصل؛ لا يعني الاختلاف بينهما دائمًا، فقد يلتقيان، فتكون الجملة كلامًا، والكلام جملة، وقد ظهر ذلك من خلال بعض الأمثلة التي ظربها ابن جني، وفي حديثه عنها، ووصفها بأن كلا منهما هو جملة وكلام، نحو: زيد أخوك، قام حمد، في حين أن بعض أن الكلام لا يكون جملـة نحو: قام حمد وأخوك جعفر بـل هو جملتان، وقد

$$
\text { - يكون أكثر }
$$

T- ولأن الجملة تعد وحدة الدرس النحوي في الدراسات اللغويـة الحديثة لذا فقد تعددت محاور البحث فيها عند المحدثين العرب بتفسير علاقتها بالكلام من جهة وتقسير علاقتها باللغـة مـن جهـة أخرى، فعلاقتها وطيدة بكل من من

فالكلام لا يدرس منفصلًَ عن اللغة إلا عند اعتباره عمـلً صوتيًا بحتا

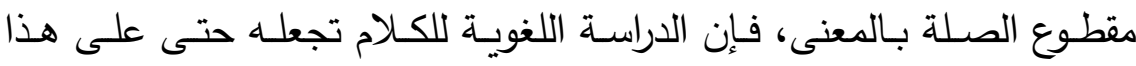
المستوى الصوتي على صلة باللغة. كمـا أن العلاقة بين الجملـة والكـلام قائمـة، وقد وضـحها علمـاء النحو القدامى، وإن كانت تعريفاتهم قد أفادت الدرس النحوي في بيان مفهوم الكلام، وبيان مفهوم الجملـة، إلا أنها لـم تحدد ضـابط معـين يلتف حولـه الباحثون بالتحليل.

V- اتصـفت الجملـة العربية منـذ نشـأتها الأولى والتي رودفت فيهـا بمسـى بـى 》الكلام《 أنها مركبة تركيبا إسناديًا يشهد بذلك عبارة الخليل ابن أحمد في 


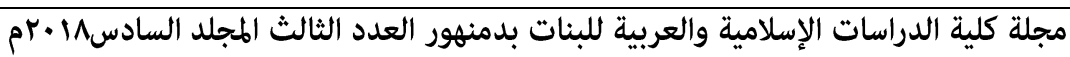
تعريفـه للإسـناد فالكلام عنده (سند ومسند)، وبهذا يتحدد مفهوم الإسـاد ومكونات عناصره في التراث النحوي منذ بكورة البحث اللغوي. 1- توالي الكثف عن التركيب الإسـادي للجملـة العربية مـن خـلال تعريفات النحاة عند مرادفة مسماها بمسمى الكلام حيث يرصدها المبرد في باب المسـند والمسـند إليـه ليكثـف بذلك عن عنصسرين أساسين يتكون فيهما التركيب الجملي الإسنادي والتي يتضـن كلمتين يحسن السكوت عليها. سواء كانت هاتين الكلمتين مصدرة بفعل مع فاعل أو مبتدأ مع خبر إذ أن

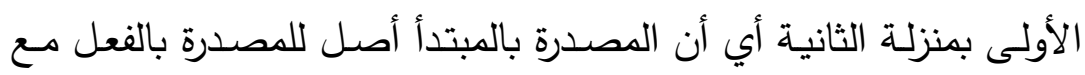
الفاعل. 9- يعطي ابن جني نماذج متعددة لصور الجملة العربية والتي ترادف الكلام فمنها الفعلية المصـدرة بفعل مبنـي للمعلوم ومنها الفعليـة المصدرة بجر ومجرور ومنها أسماء الأفعال وأسماء الأصسوات لتضـع كل هذه التراكيب تحت مسمى الجملة العربية والتي سميت واتصفت بالأساس بالإسناد وهذا أمرُ ينبـ عن أن جميع الجمل العربية تتصب تحت مركب واحد مسماه التركيب الإسنادي ولا شيء سواه حيث جعل الأصناف كلها تحت مسمى الجملة أو الكلام. - الإسلادي

• ا - يتفق النحـاة على أن الكـلام مـا تكـون مـن كلمتين وأفـاد ويسـى أيضًا بالجملة ومفـاد ذلك أمسران: أ- لتسوية بـين مسـىى الجملـة والكـلام، بالإسناد ضمنا حيث توافر ركني الإسناد وذلك عند عبدالقاهر . 1 ا - يعد الزمخشري أول من صـرح بالإسـاد شرطًا من شروط الجملة؛ إذ أن إن الكـلام عنده أو الجملة كلمتين أسندت إحداهما إلى الأخرى ولم يشترط

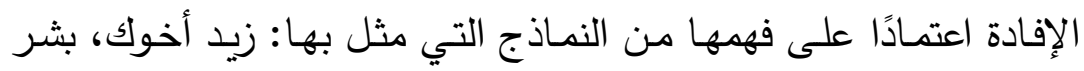
صاحبك، ضرب زيد، انطلق بكر . فقد يكون التركيب مكون من اسمين أو من فعل واسم على ما هو واضتح بالأمثلة. 


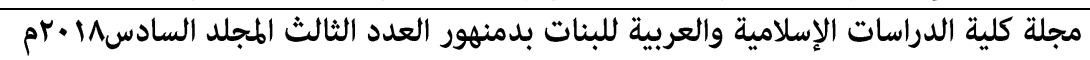

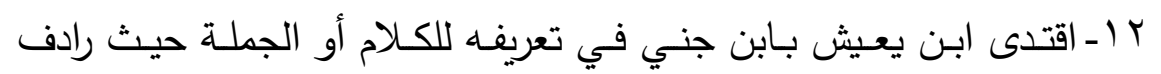
بينهما إلا أنه طبق تعريفه على أمثلة الزمخشري مشيرًا إلى الإسناد الذي نص عليه الزمخشري في تعريفه.

بر ـ اختص ابـن الحاجـب الكـلام بالإسـناد لتتميز الجملـة العربيـة الإسـنادية بالعنصر 》الثالثش لمكوناتها وهو الإسناد.

ع ا ـ انفـراد الرضــي بمخالفـة مـن سـبقه في التقرقـة بـين مصـطلحي الكـلام والجملة.

فالجملة عنده ما تضدن الإسناد الأصلي سواء كانت مقصودة لذاتها أو

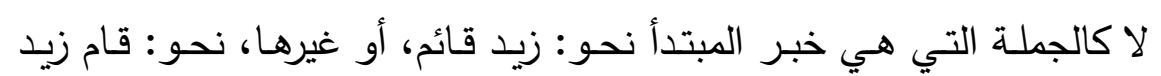
وبعت، وأنت حر، وهل أنت قائم، وليتك، ولعلك قائم، واضرب، ونحو: زيد أبوه قائم، وزيد قائم أبوه.

فيخرج المصدر وأسماء الأفعال والمفعول والصفة المشبهة والظرف مع الظع ما أسندت إليه. لأن كل هذا ليس إسنادًا أصليا.

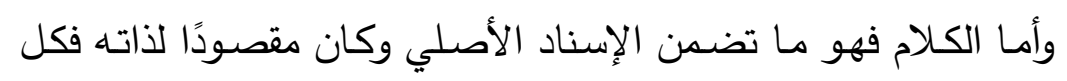
كلام جملة وليس كل جملة كلامًا. ماسيفسر الرضي عنصر الإسناد أو مكون الإسناد ثالث العناصر والمكونات التي تتكون منها الجملة العربية ليخصه بالإسناد الأصلي الذي هو رابطة الإنة

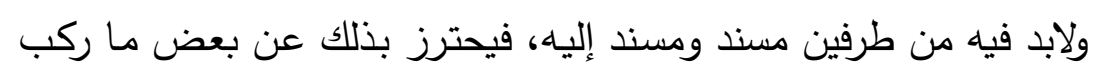

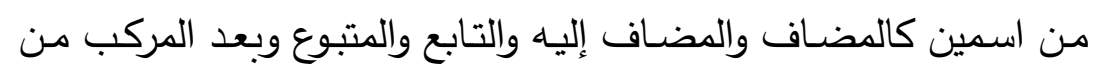

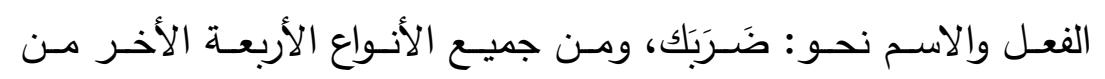
التركيبات الممكنة بين الكلم الثلاث وهي (اسم مـع حرف، وفعل مـع فعل، أو حرف، وحرف مع حرف).

فأحد أجزاء الكلام هو الحكم أي الإسناد الذي هو رابطة كما ذكر • ولابد هرد

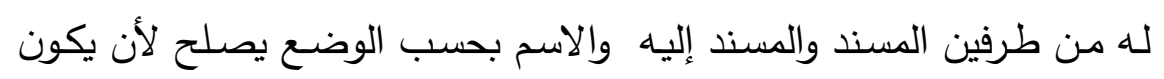




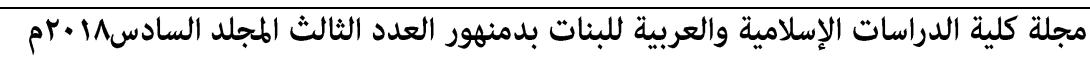

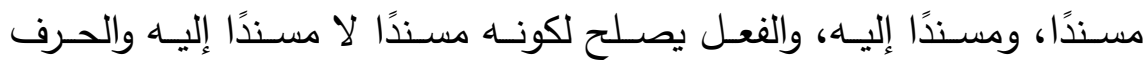
لا يصلح لأحدهما. أما الاسم فلأنه يدل على الثبوت لثبوته يصلح للإخبار عنه والإخبار به لذلك أتى مسند ومسند إليه. وأما الفعل فلأنه يدل على الحدث والحدث غير ثابت بل متغير فيصلح للإخبار ببه وليس الإخبار عنه وأمـا الحرف فلا يصلح لهذا ولا ذاك لأن معناه مع غيره وليس معناه في نفسه. 7 ا - يحدد الرضـي مكونات التراكيب الإسنادية فالاسمان يكونان كلامـا، لكون أحدهما مسندًا والآخر مسندًا إليه، وكذا الاسم مع الفعل لكون الفعل مسندًا والاسم مسندًا إليه والاسم مع الحرف لا يكونان كلاما، إذ لو جعلت الاسم مسندًا، فلا مسند إليه، ولو جعلته مسندًا إليه فلا مسند. وأما نحو: يازيد ف لسد 》يا《ي مسد 》دعوت فهذا يدل على أن تركيب النداء تركيب إسنادي عند النحاة في التراث النحوي وهو المقرر من أمثلة ابن جني. والفعل مـع الفعـل أو الحـرف لا يكونـان كلامـا لعدم المسـند إليـه، وأمـا الحرف مع الحرف فلا مسند فيهما ولا مسند إليه. يعرف ابن هشام الجملة على أساس تركيبي فيرى أنها تركيب إسنادي فعلي أو اسمي، كما أنه يرى أنها أعم لأنها تقع على ما يفيد وما لا يفيد. أما الكلام فلا يوضـع إلا فيما يفيد. ويوافقه في هذا السيوطي. V ا التقاء الباحثين المحدثين في نقطة مـع النحاة في استقلالية المعنى في الكلام بـ الإفادة، ووجود ركني الإسناد ولو تقديرًا بالتركيب أو التأليف. 1 ا-كان من مراحل التطوير للجملة من خلال نظرة المحدثين أنهم: أ- لا يشترطون الإسناد مثلما لجأ إليه المتأخرون أمثال الرضسي وابن هشام ومن تبعهم. 


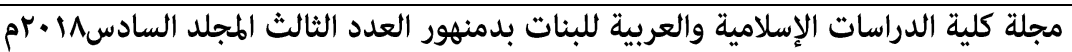
ب- يعترفون بوجود الجملة (غير الإسنادية)، ولا ينبغي التأويل والتقدير معها، كما أنه ليس بالضـرورة أن تحتوي الجملة على العناصر كلها، فقد تخلو الجملة من (المسند إليه) لفظا أو (المسند) لوضوحه وسهولة تقديره. ج- يعترفون بوجود الجملة ذات الطرف الواحد المؤدية لمعناها اعتمادًا على قرائن الأحوال والسياق والموقف اللغوي الذي يكون فيه الكلام وهو كبرى القرائن

د- يعترضـون على تقدير النحساة في مثل (يازيـد) ونحسوه مـن الجمـل ذات الطـرف الواحد مسـتلين في ذلك بـآراء بعض النحساة أمثال أبـي على في الفارسي وتلميذه ابن جني في أن مثل هذه الجمل ذات الطرف الواحد كافية في إفادة المعنى، فلا جدوى من تقدير وتأويل.

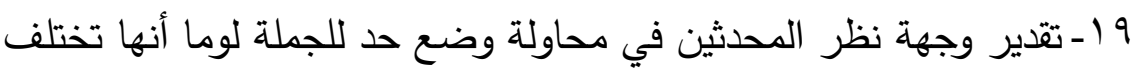
النظرة في حكمها باختلاف صور الجملة. • . - على الرغم من محاولات المحدثين إحداث تطوير للجملة بوضـع ضـابط وحد لها إلا أن الجملة لم تحظ بتعريف شامل دقيق عند هؤلاء المحدثين، وذلك لصعوبة ضبط أحوالها ضسبطا دقيقًا، ولكونها تتمتع بأبعاد عديدة: صوتية، ونفسية، وذهنية، وتركيبية، ودلالية. ا ا-حاول الدكتور مهدي المخزومي أن يقدم في تعريف الجملة مفهوما جديدًا يتفق في غالبه مـ تعريف ابن جني القائل بأن الجملة اكل لفظ مستقل بنفسـه مفيد لمعنـاهی فلم يثترط غير الاستقلال والإفـادة إلا أنـه يعود مرة أخرى فيشترط الإسناد مقوما من مقومات الجملة فالتركيب الذي لا إسناد فيـه (أسـلوب خـاص) كالنداء يسميه 》المركب اللفظيه فهو عنده ليس جملة فعلية ولا جملة غير إسنادية، وإنما هو مركب لفظي بمنزلة أسماء الأصوات يستخدم لإبلاغ المنادى حاجة أو لدعوته إلى إغاثة أو نصرة أو هو هرحئ نحو ذلك. 


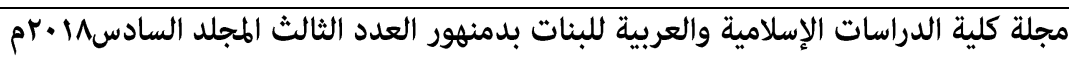
Y Y -هل يسمي المخزومي - بناء على فكرة قوله بالمركب اللفظي - كل تركيب غير إسنادي مفيد (مركبا لفظيا)؟ أو أن هذا (مصطلح خاص) لما عدا الإسناد?

وهل أسماء الأصسوات عنده مركب لفظي كما يفهم من تشبيه أسلوب النداء بها؟ حيث أنه وصف أسلوب القسم بأنه أيضًا (أسلوب خاص) فهل نفهم من هذا أنه هو الآخر 》هركب لفظيش.

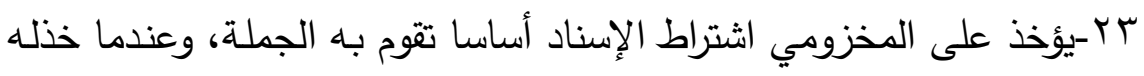
الإسناد في إحداث فكرة تامـة في أسلوب الشرط؛ لأنـه يتكون من جملتين تربطهما أداة شرط كل منهما جملة تحقق فيها شروط الإسناد، ومع ذلك لم يكتمل معنى كامل، ولا فائدة يحسن السكوت عليها تراجع بعض التراجع فقال: ليست جملة الثرط جملتين إلا بالنظر العقلي، والتحليل المنطقي، أما بالنظر اللغوي فجملتا الشرط جملة واحدة، وتعبير لا يقبل الانشطار ، لأن الجزئين المعقولين فيها إنمـا يعبران معـا عن فكرة واحدة، لأنك إذا اقتصرت على واحد منهما أخللت بالإفصاح عما يجوز في ذهنك وقصرت عن نقل ما يجور فيه إلى ذهن السامع وسمى كل واحدة من جملتي الثرط والجواب (عبارة)، أي عبارة الثرط وعبارة الجواب. ع Y-يؤخذ على المخزومي ماذا يقول عن (قائم أبوه) في جملة مثل (عحم قائم أبوه) فقد تحقق الإسناد بين قائم وأبوه وهي مع ذلك ليست في هذا السياق جملة مستقلة.

ه广-رأى البحث: تخبط المحدثين في محاولتة للخروج عن منهج القدامى في بيان مفهوم الجملة بوضع حد معين لها وإنما لم يتمكن القدامى من وضـع حد وضـابط لها ليس لقصور منهم وإنما لأن الجملة تتعدد صـورها مدـا يجعلها عصية في تعريفها وتحديد ضـابط لها أمسام اختلاف هذه الصسرر والأساليب والتراكيب الواردة فيها. 


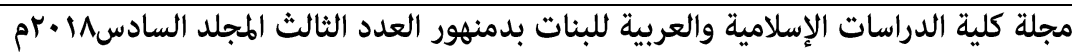
جr-رأى البحث أن ما عابه المحدثين على القدامى من النحاة العرب وقعوا فيه الإبه وهو عدم تحديد ضـابط للجملة. فلم يتمكنوا من إحداث تطوير في وضـع (حد) لها.

Y Y V اعترض حماسة على القول بأن الكلمة الواحدة تعد جملة على نحو ما زعم إبراهيم أنيس بدعوى من أي نوع من الجمل تكون؟؟

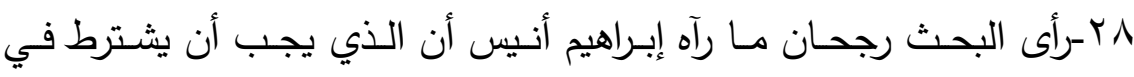
الكالام لئلا يكون لغوًا هو حصسول الفائدة وتمامها. ومن ثم فبتحقق هذا الشرط في كثير من العبارات يعد جملا وإن خالف القول بهذا برجشتراسر . وץ-من صور الجملة العربية يلاحظ أن نصيب الاسم هو الأكبر على نحو هو هو تحديد سيبويـه له فهو عامل مشترك في الجملة الاسمية والفعلية، فلابد في الاسمية من مسند إليه وهو الاسم، وكذلك في الفعلية، فهو شرط الإفادة

$$
\text { في الجملة. }
$$

• بـالجملة الفعلية يلزم أن يكون الفعل فيها مقترن بزمن وإن اختلف مسماه عند الجمهور فالبصـريون على تسـيته بمـاض ومضـارع وأمـر وشـموله لكأنواع الثالثة المذكورة.

والكوفيون يقصـرونه على الماضـي والمضـارع ويـرون أن الأمـر مقتطع من المضـارع بزيـادة لام الأمر وسواء هذا أو ذالك فهو حدث مصسوب بزمن

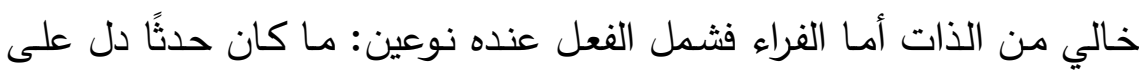
زمن أو ذاتًا دلت على زمن أيضًّا، لـلك تنوعت الأقسـام عنده إلىى: مـاض ومستقبل ودائم.

فالأول الماضي والثاني المضارع أما الثالث فأراد بـه اسم الفاعل وبذلك

$$
\text { تحدث المخالفة بينه وبين الجمهور • }
$$

وأرى أنـه: غير مخطئ في زعمـه (يشهـ لـه مفاد) عبارة سيبويـه في تحديده لنوعية الفعل بقوله: (أما الفحل فأمثلته أخذت من لفظ أحداث الأسماء) فقوله أحداث الأسماء يدخل فيها كل ما دل على حدث سواء مصحوب بزمن 


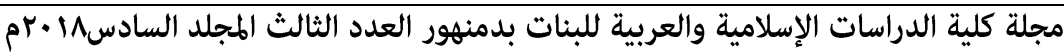
فقط أو مصـحوب بزمن وذات في نفس الوقت نحسو: اسم الفاعل حيث يدل على زمن وهو الدوام والثبوت وبـلك تكون إشـارة الفراء ليسـت بغريبـة على أصناف الحدث أو على أصناف الزمن وإنما الغريب فيها أن الجمهور يوقف الفعلية على الحدث المقترن بالزمن بعيدًا عن الحدث المقترن بالزمن والذات

وخاصــة وأن اسـم الفاعل يقوم بـنفس مـا يقوم بـه الفعل على مـذهب

الجميع من إحداث تأثير ما فإذا قلت زيدٌ ضـاربٌ عمرًا فعمرًا وقع في موضـع

المفعولية وإذا قلت ضارب زيدٌ عمرًا وقع زيد في موضع الفاعلية.

فلا غرابة في إعداد اسم الفاعل فعل دل على الدوام على ما ذهب إليه

اب-الإجماع عند القدامى على أن الجملة لا تنقسم إلا إلى قسمين: اسمية، وفعلية. فالاسمية التي صدرها اسـ، كزيـد قائم وهيهات العقيق، والفعلية التي صدرها فعل كقام زيد، وضـرب اللص وكان زيد قائما وظننته قائما

$$
\text { ويقوم قم. }
$$

ץ"-خرج الزمخشري من القدامى في تقسيمه للجملة عن الإجماع في قوله بأن التقسيم على أربعـة أصـرب: فعلية واسمية وشرطية وظرفيـة، وانتقاد ابن يعيش التقسـيم إذ أن الأصـل التقسـيم قسـين فعليـة واسـية ومـا أتىى بـهـ الزمخشري فهو تقسيم شكلي على أن هناك من يوافقه ومن يخالفه. سب-خرج ابن هشـام عن الإجماع أيضًا إذ أن التقسيم عنده يقتضسي أن تكون القسمة ثلاثة أقسام فعلية واسمية وظرفية. ؟َ-ورأى البحث أن العرض للتقسيمات في تلك المرحلة العصر القديم يظهر تعيين الجملـة اسـية وفعليـة مـن خـلال عناصـرها الموجـودة وعن طريـق الحذف والاستتار يكمل للجملة مـا أرادوا مـن قوالب. فربمـا كان في نوع الجملة خلاف لاختلاف التقدير، أو لاختلاف النحاة حولها. 


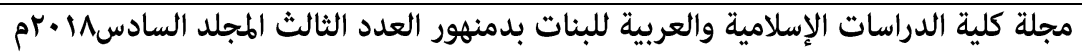

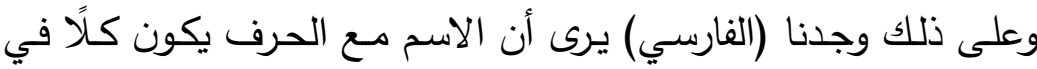

النداء نحو (يازيدُ). وأجيب بأن (يا) سدت مسد الفعل وهو أدعو أو أنادي. ورأينا (ابن طلحة) يزعم أن الكلمة الواحدة قد تكون كلَ إذا قامت مقام

الكلام لـ (نعم) و(لا) في الجواب، ورد بأن الكلام هو الجملة المقدرة بعدها.

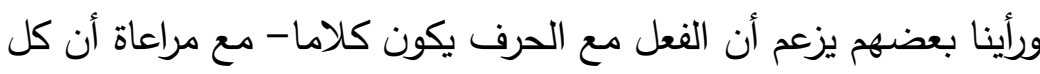
كلام جملة في نحو: (ما قام) بناء على أن الضمير المستتر لا يعد كلمة. هץ-انتقد بعض النحاة الزمخشري في زيادته للشرطية والظرفية إذ أن تقسيمها عنده إلى اسمية وفعلية وشرطية وظرفية يعد عند هؤلاء تقسيم لفظي مرده الجملة الاسمية والجملة الفعلية وكان صـاحب هذا النقد ابن يعيث ووافقه بعض الدارسين المحدثين. على حين وافق الزركثي مذهب الزمخثـري حيث يعد جملة المجـازاة جملة واحدة إذ عقد بين طرفيها بالرباط الواصل بينهما، فإذا انحل هذا الرباط الواصل بين طرفي المجازاة عاد الكلام جملتين كما كان. وكذلك وافق الزركشي الزمخشري في القول بالجملة الظرفية. جr-اختلف الزركثي مع الزمخشري في تمثيله للجملة الظرفية، حيث مثل لها الزمخشري بنحو (خالد في الدار) فالجملة الظرفية هي المصدرة بالجـار والمجرور مخبرًا بها عن مبتدأ كما في المثال. أمـا الزركثـي فعنـده الجملـة الظرفيـة هـي المصـدرة بظـرف أو جـار

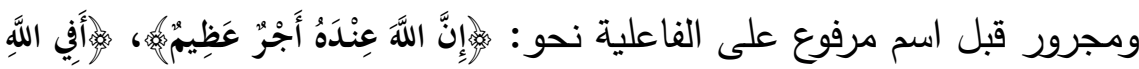

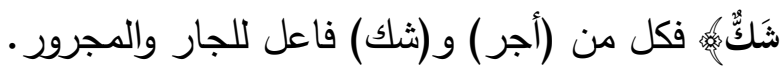
V" Vـوافق فخر الدين قباوة مـن المحدثين على مذهب الزمخشـري في القول بالجملة الشرطية قسمًا ثالثًا من أقسام الجملة بعد الاسمية والفعلية. وهي التي يكون صدرها أداة شرط نحو: من طلب العلى سهر الليالي، معتمدًا على إشارة الخليل والمبرد إلى الجملة الثرطية، ثم جاء الزمخشري ونص مل 


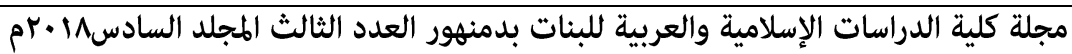
مץ-الظرفية عند ابن هشام هي المصدرة بظرف أو جار ومجرور نحو: أعندك

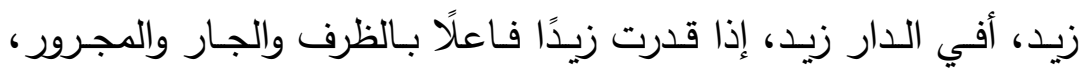
لا بالاستقرار المحذوف، ولا مبتذأ مخبرًا عنه بهما. وץ-العبرة عند ابن هثام في تقسيمه بصدر الجملة من المسند أو المسند إليه

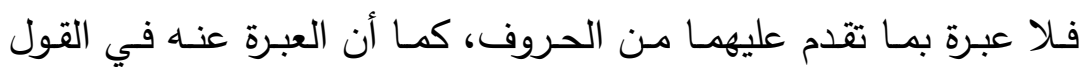
بالتصدر ما هو صدر في الأصل من الأسماء التي في نية التأخير. • ـ-اتبـع السـيوطي ابـن هثـام في التقسـيم إلـى اسـية وفعليـة وظرفيـة أمـا الثرطية فعنده من قبيل الفعلية، لأن العبرة بالمصدر (المسند) أو المسند إليه، ولا عبرة بمـا تقدم عليها من الحروف نحو (إن قام زيد) فمن قبيل الفعلية.

أـــم يعـرب الـدكتور إبـراهيم أنـيس عـن تحديـد موقفـه مـن التراكيـب غيـر الإسنادية والجمل ذات الكلمة الواحدة على حد قوله من أي نوع من الجمل تكون؟ إلا أنـه شـل بدراسـة نظـام الجملـة في إطـار تقسيم النحـاة القدماء مهتمـا بوضــع المسـند إليـهـ في الجملـة، والوصـل، والفصـل، ومواضــع المتعلقات في الجملة. Y گ-صـاحب نظريـة القول بتقسيم الجمـل العربية إلى نوعـان: إسـادية وغير إسنادية هو الدكتور عبدالرحمن أيوب، أما الجمل الإسنادية، فتشمل الجمل

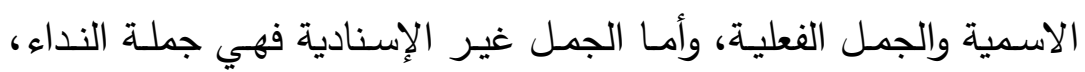
وجملة نعم وبئس، وجملة التعجب، ووافقه في هذا التقسيم د/ حمد حماسـة عبداللطيف. بـــرأى البحـث أن تقسيم بعـض الدارسـين المحـدثين للجملـة إلـى صــرى وكبرى، وتفريع الكبرى إلى عدة تقسيمات مستنبطة من خلال التراكيب، ووجود هذه التقسيمات في التراكيب العربية على الرغم أنـه معتمد على وفى وفي بلومفيد في تعريف الجملة مما يدل على سعة اللغة العربية، وهي التي تعد إحدى اللغات السامية، والتي يمكن أن تجد فيها العامل المشترك بين كل 


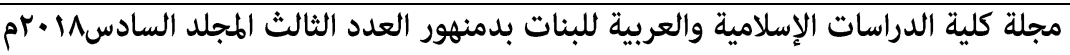
منها، مما يمكن الدارسين والباحثين من الكثف عن الخصـائص الكامنـة فيها، والوقوف على كثير من أسرارها، والبحث عن وجوه الاتفاق بينها، وإبـراز مـا قد يفترقا فيها، فتتميز كل منها بالخصـائص العامـة والخاصـة على السواء، مما يثري الدراسات اللغوية الحديثة بالبحث العلمي المشترك

$$
\text { بين العرب والغرب على السواء. }
$$

؟ ـ-يؤخذ على الباحثين المحدثين من العرب ومنهم الدكتور مهدي المخزومي أنه لجأ في تقسيمه للجملة إلى النظر العقلي الذي عابه على النحاة في اعتبارهم كلا من ركني الشرط لجملةه، ثم أنه بعد مـا أقر النحاة على تقسيمهم للجملة إلى اسمية وفعلية، ووصف تقسيمهم بأنه (تقسيم صحيح يقره الواقع اللغوي) استدرك في الحال بقوله: (ولكنهم بنوا دراسـاتهم اللغويـة على غير منهجها، فلم يوفقوا إلى تحديد الفعليـة من الاسـية، ووصف التحديد بأنه تحديد ساذج يقوم على أساس من التقريق اللفظي المحض)، وتتمثل سذاجتهم في أنهم عدو جملة (البدر طلع) جملة اسمية وهو يعدها جملة فعلية، لأن الجملة الفعلية عنده اهي الجملة التي يدل فيها المسند على التجديد أو التي يتصف فيها المسند فاعلًاه. ويقصد بذلك أنه يجوز أن يتقدم الفاعل على فعله. فيكون الاسم المتقدم فاعل للفعل المذكور وبذلك فهذه الجملة من قولك (البدر طلع) جملة فعلية وبهذا الـرأي قال بـه الكوفيون والأخفش مسن قبلـه. وقد رد المبـرد على هذه هـه الدعوى من قبل بقوله: لافاذا قلت: (عبدالله قام)، ف عبدالله رفح بالابتداء، وقام في موضع الخبر • وضميره الذي في قام فاعل. فإن زعم زاعم أنه إنما يرفع (عبدالله) بفعله فقد أحال من جهات: منها: أن (قام) فعل، ولا يرفع الفعل فاعلين، إلا على جهة الاشتراك نحو: قام عبدالله وزيدّ، فكيف يرفح عبدالله وضمير؟ وأنت إذا أظهرت هذا الضمير بأن تجعل ئل في موضـعه غيره بـان لك، وذلك قولك: عبدالله قام أخوه، فإنمـا ضـميره في

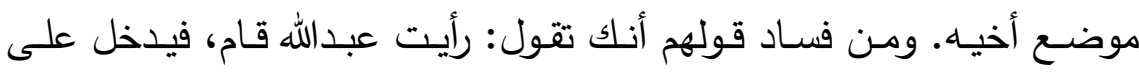




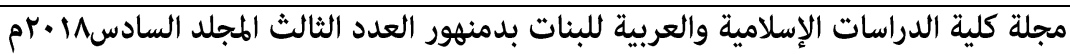
الابتداء ما يزيله، ويبقي الضمير على حاله، ومن ذلك أنك تقول: عبدالله هل قام؟ فيقع الفعل بعد حرف الاستفهام، ومحال أن يعمل ما بعد حرف الاستفهام فيما قبله.

ومن ذلك أنك تقول: ذهب أخوك، ثم تقول أخواك ذهبا، فلو كان الفعل عـاملً لعمله مقدما لكان موحدًا، وإنمـا الفعل في موضـع خبر الابتداء رافعًا للضمير - كان - أو خافضًا أو ناصبًا، فقولك عبدالله قائم بمنزلة قولك عبدالله موله ضربته، وزيد مررت بهه.

○ـ-وافق بعض الدارسين المحدثين المبرد والنحاة في أن الاسم المتقدم يعرب مبتدأ والفعل الواقع بعده جملـة في الأصـل وقعت موقع الخبـر، وقامـت

$$
\text { بوظيفته على سبيل النقل، فصار خبرًا (مركبًا). }
$$

جـ -سوى الدكتور مهدي المخزومي بين ثلاث نماذج تحت اسم الجملة الفعلية (طلع البدر، والبدر طلع، وانكسر الزجاج وكسر الزجاج) كلها من قبيل الجملة الفعلية والمسند إليه في كل منها فاعل، ويرى أننا في حاجة إلى إفراد النمـاذج في كل منها على حدة لا إلى ضـمها تحـ نمـوذج واحد

$$
\text { نضطر معده إلى التأويل والافتراض. }
$$

\& V تحديد الجملة الاسمية عند المخزومي لم يخرج عن إطار النحاة القدامى، افهي التي يدل فيها المسند على الدوام والثبوت، أو التي يتصف فيها إنها المسند إليه بالمسند اتصـافا ثابتًا غير متجدد، أو بعبارة أوضـح هي التي كيون فيها المسند اسمًا

^ـ ـيؤخذ على المخزومي أنها لم يصـف الكلمة، ولم يبين أجزاء الكلام ومن صم نتساءل مع الدكتور حمد حماسة عبداللطيف: هل كل الأسماء تصلح لإفادة الثبوت وعدم التجدد إذا أخبر بها عن اسم ما؟ وإذا كان اسم الفاعل يدل على التجدد والحدوث كما يقول النحاة، فهل إذا أخبرنـا بـه عن اسم مثل (كما قـائم) كانــت هـذه الجملـة فعليـة عند الـدكتور المخزومسي؟ أو أو 


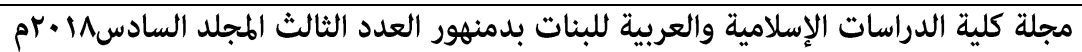

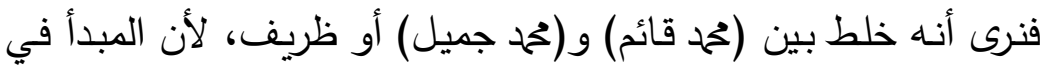
الفعلية عنده إذا كان المسند فعل أو يفيد التجدد والحدوث. فالأسـئلة التي طرحها حماسـة مطلوب الإجابـة عليها، لأن الصـورة لـم تكتمل بعد لدى المخزومي.

وبناء على منهجه (ححم قائم) فعلية للتجدد والحدوث مثله في ذلك الجملة التي مسندها فعل مثل (طلع البدر) و(البدر طلع) فلم يخرج إذن للاسمية إلا صورة واحدة وهي ما كان المسند فيها اسما نحو (حمد ظريف) وهي في نفس الوقت تدل على الثبوت والدوام، ومن ثم يُنتقد مذهبه بأن المخزومي في دراسته للجملة كان يعتمد على أساس ما، ثم ينقضها إذا لم يطرد لله في غيره. 9 §-أسرف المخزومي في رمي النحاة بالخلط والجهل والإفساد، وأسرف في نقدهم دون أن يقدم البديل في الحالات، وكـان لأشبـه بـه أن يحترم لهم وجهة نظرهم، وأل يأخذهم بما أخذهم به من عنف وقوة، مـع أنه لم يخرج عنهم في كثير اللهم إلا مـا سماه 》مركبًا لفظيًا وقف به في مرحلة غير محددة، فلا هو جملة إسنادية، ولا هو جملة غير إسنادية ولا هو استقصى كل هذه النماذج وصنفها بحيث يستقيم لله ما يريد. • 0-ظهر مـن مناقثـة حماسـة لجمـل ابن هشـام أنـا يختلف معـه، وربمـا مـح النحاة في مذهب الجمهور في تصنيف الجملة وتقسيمها وانفراده بتقسيم يخالف النحاة، وقد ظهر ذلك من خـلال عدم الموافقة مـع ابن هشام في بعض التراكيـ. ليخلص من ذلك إلى بنـاء تصـنيف جديد حيـ انتقد القدامهى في اهتمامهم الثديد بركني الجملة. 10يتميز تقسيم حماسـة للجملـة، بأنـه اعتمد في تقسيمه على إعـادة تقسيم الكلمة. كما أنه بنى تقسيمه على أسس معلنة حيث أعلنها ووضحها، فجاء التقسيم مطابقًا لتلك الأسس. roو في الجملة. وخروجها عن المألوف من التقسيم القديم الذي عهد وحفظ في 


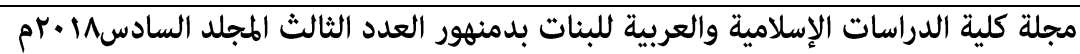
التراث النحوي، والذي يصعب معه محوه أو التتازل عنه أو استبداله، بل التل أن ما أتي به صعب تنفيذه على أرض الواقع اللغوي من حفظ لقواعد قد دونـت ورسـخت في المصـادر ولكثرة هـذه التقسـيمات الجديـدة واسـتحالة

تطبيقها.

به-اختلاف المحدثين مع الموروث النحوي في تسمية بعض التراكيب بالجملة الندائية فبعضهم يطلق عليها مسمى (مركب لفظي)، ولا يرتفع إلى منزلة الجملة، ولا يصـح تسميته بالجملة أيضًا على نحو ما يراه الدكتور مهدي المخزومي، في حين يراها الدكتور عبدالرحمن أيوب والدكتور محم حماسـة عبداللطيف أنها مـن الجمـل غيـر الإسـنادية وهكذا اختلافهم في جملـة الثرط حيث انشطرت شطرين عند ابن هثام في حين أنها جملة واحدة عند الدكتور مهدي المخزومي لا تقبل الانشطار .

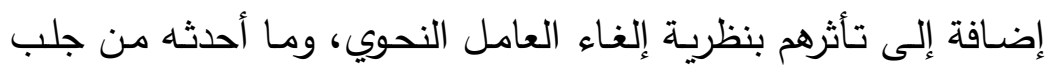
للأفكار، فهذا وإن كان مفيدًا من جهة رواج الفكر ونمائه والكثف عن كثير من مدخلات وأسرار اللغة العربية إلا أنه يحتفظ للسابقين بمنحهم القويم والسديد من وجهة نظري لأنـه الأخصر والأضسبط، ولأنها منهج حُفظ وحُفر في دراسـة التراث النحوي لا مناص عنه. ـه_قد يتقق مسمى التركيب الجملي في الدراسات اللغوية والنحوية الحديثة مع

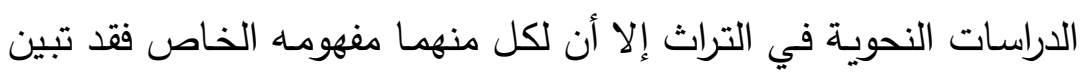
اشتراك مسـى الجملة الكبرى والجملة الصـغى كقسم من أقسـام التراكيب الإسنادية في التقسيم الثنائي القديم وأيضًا في الحديث كما ظهر عند ابن هثـام وبعض الدراسين في النحو الحديث الذين تأثروا بتعريـف بلومفيد للجملة. هــاشـتراك مصـطلح الجملـة الظرفيـة بين المتقدمين والمتأخرين في التراث

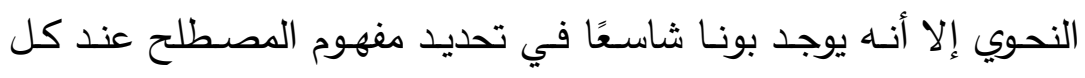

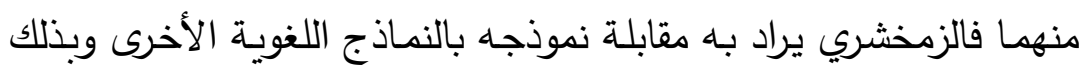




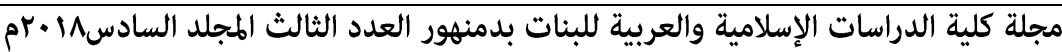
يقف على ما يميزها من خصائص لغوية بينما ابن هشام يلحظ في مفهومه لها الاعتبارات الذهنيـة والمذهبية لمـا يحتمله هذا التركيب الإسـادي في قولك (أعندك زيـد) فيحتمـل الظرفيـة والاسـمية والفعليـة على حد توجيـه

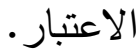

Tهـاتفاق حماسة مع النحاة في مسمى التركيب الفعلي للجملة إلا أنه يختلف النف معهم في هذا التراكيب من حيث قصـره على أنواع محددة من التركيب الشامل في القديم.

V V-يتفق حماسـة مـع النحـاة البصـرين في عدم التوسـع بتقديم الفاعل على الفعل لأنه يحدث اللبس وأيضًا يتفق معهم في المطابقة في النوع وعدم المطابقة في العدد وأن المطابقة في العدد لهجة بعض العرب. ^هـوجود ثمة تشابه بين نحاة العصر القديم ونحاة الحديث في دراستهم للجملة الظرفيـة مـن حيـث اسـتخدام نفس المصـطلح للتركيـب بمسـمى الجملـة الظرفية. واعتماد الظاهرة أو النموذج أو التركيب الوارد في التراث اللغوي متفق عليه تركيبا إسناديا عند كل منهما. هـاختلاف نحاة القديم مع نحاة الحديث في دائرة البحث في الجملة الظرفية ويرجع ذلك إلى توجيه الاعتبار وليس النموذج نفسه. فالاعتبارات في القديم لغوية ومذهبية بينما في الحديث ترجع إلى تحليل التركيب لإبراز الخصائص التي تميز المركب ليدلل على كونه تركيبا مستقلً. من تراكيب الجملة الإسنادية. • 7-توافق وجهات النظر بين النحاة والمحدثين في مسـى الجملـة فقط في الجملـة الوصفية بينما اختلفا في اتباعها بالوصفية فالتقسيم القديم على تسميتها بالاسمية والحديث على تسميتها بالوصفية. الا-توافق النحاة على خاصسية هذا النوع وانفراده بخصسائص تميزه عن غيره بشروط وضوابط محددة.

r T-اعتماد النماذج الواردة في اللغة فيما بينهما. 


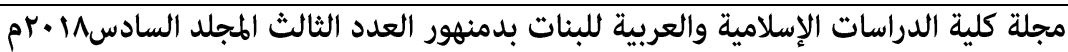
ب7 استحداث مسمى الجملة الوصفية يرجع إلى نحاة العصر الحديث. ـ \-اعتبار التركيب الوصفي تركيبا إسناديا مستقلا عن التركيب الاسمي لأن له خصائص انفرد بها وتميز بها عن غيره مما يجعله يستحق الانفراد. 07-بضـيمة الخصـائص العامـة للجملة الثرطية والتي رصدها الدكتور على أبو المكارم في تحليله لها تجلى لنا تميز هذه الجملة بنمط خاص متميز عن أنماط الجملة العربية، سواء في مكوناتها، أو علاقاتها أو خصائصها، أو ظواهرها، فهي جملة متعددة العناصر والأطراف الإسنادية، وهي مركبة دائما، وتركيبها ذو طبيعة خاصة بها، وليست في مجموعها صالحة للنسخ أو الامتداد أو التطابق، إلا أن كلا من النسخ والامتداد والتطابق أمر وارد بالنسبة للطرفين الإسـاديين فيها، وهي من ناحية ملتزمـة الترتيب، ثابتة الموقع، ومن ناحية أخرى تتسم بقدر من مرونـة الترتيب في مجال تحديد موقع أحد عناصرها، وبرغم هذا تعد نوعًا من أنواع الجملة العربية مختلفا عما سواه. 


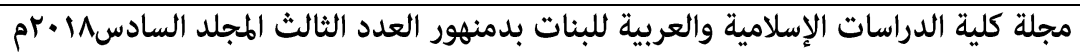

\section{ثبت الاصسادر والمراجع}

ا -إتجاهات البحث اللساني- ميلكا إفيتش - ترجمة سعد مصلوح، ووفاء كامل-

المركز الأعلى للثقافة، الجزء الثاني.

Y-إحيـاء النحو - للأستاذ إبراهيم مصـطفى - قدم لـه حمد عبداللطيف حماسـة-

$$
\text { مكتبة الآداب. }
$$

ب-إحيـاء النحـو والواقـع اللغـوي- دراسـة تحليليـة نقديـة- تـأليف: د/ أحمـد خحم عبدالراضي- الناشر مكتبة الثقافة الدينية، طا، V V. • rم.

ع-أسرار العربية- لابن الأنباري- تحقيق: محمد بهجت البيطار .

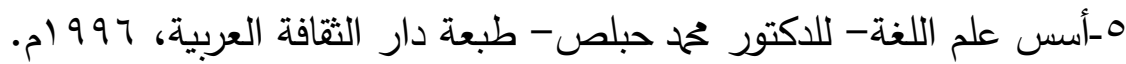
Y-الأصول في النحو - لابن السراج- تحقيق: الفتلي. V-أصول النحو في نظر النحاة، ورأي ابن مضـاء، وضوء علم اللغة الحديثللدكتور / خمح عيد- الناشر عالم الكتب.

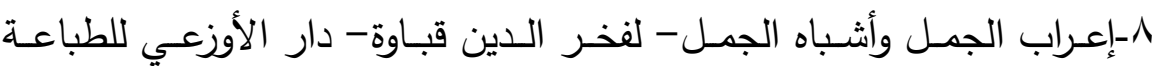

$$
\text { والنشر - بيروت - لبنان. }
$$

9-الأفعال في اللغة العربية- دراسة تحليلة من خلال التراكيب القرآنية.

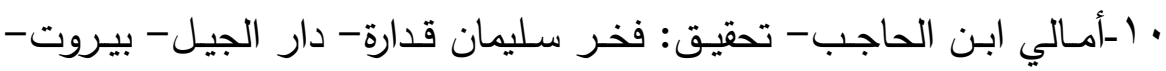

$$
\text { عمان } 9199
$$

1 أوضـح المسالك إلى ألفيـة ابن مالك- لابن هشـام- ومعـه عدة السـالك إلى تحقيق أوضح المسالك - لمحي الدين عبدالحميد، دار الطلائع.

r ا بحوث ألسنية عربية- ميشال زكريا، ط المؤسسة الجامعية للدراسات والنشر

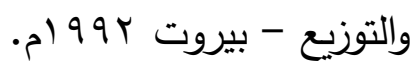

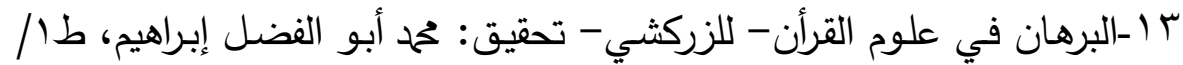
T T اهـ - 90 ام- دار إحياء الكتب العربية. ع ا-بناء الجملة الاسمية- لمحمد حماسة عبداللطيف. 1 -بنـاء الجملـة بـين العربيـة والصـينية- دراسـة تطبيقيـة وتقابليـة على سـورة

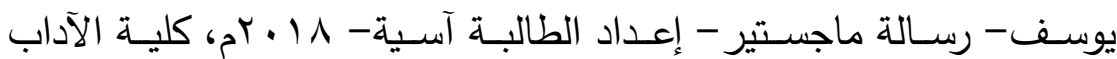




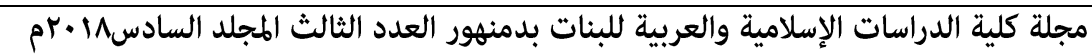

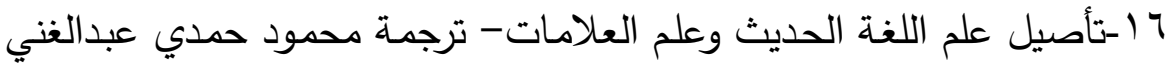
ومراجعة محمود فههي حجازي - ط المجلس الأعلى للثقافة. V ا التراكيب الإسنادية الجمل الظرفية- الوصفية- الشرطية- للدكتور على أبو المكارم- مؤسسة المختار - القاهرة. 1 ا -التصريح على التوضيح- للشيخ خالد الأزهري.

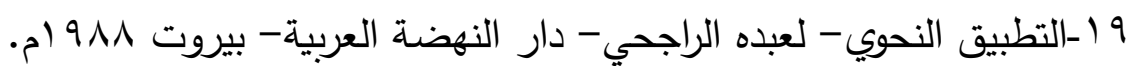

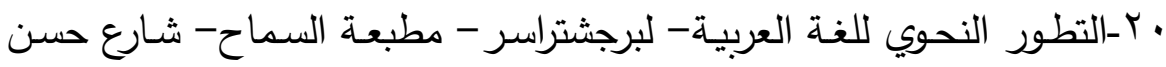

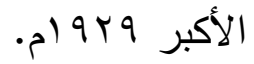

ا اY-تلخيص المفتاح- للخطيب القزويني- القاهرة. r Y-جامع الدروس العربية- مصطفى الغلاييني - راجعه عبدالمنعم وعبدالعزيز

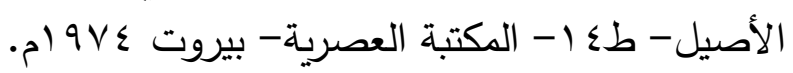

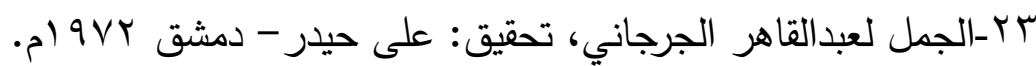

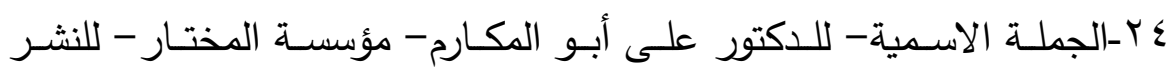

$$
\text { والطباعة- القاهرة. }
$$

ه广-الجملة الفعلية بسيطة ومركبة- دراسة تطبيقية على شعر المتنبي- مؤسسة

$$
\text { شباب الجامعة- الإسكندرية. }
$$

צr-حاشية الأمير على مغني اللبيب- مطبوع بهامش مغني اللبيب لابن هشامدار إحياء الكتب العربية- بدون تاريخ.

NV ^r -حاشية الصبان على شرح الأشموني في منهج السالك للأشموني ومعه شواهد العيني- دار إحياء الكتب العلمية- فيصل عيسى البابي الحلبي. 9ץ-الخصـائص لابن جني- تحقيق: حمح على النجار - طبعـة الهيئة المصـرية العامة وأخرى دار الكتب المصرية. • ب-الخواص التركيبية للهجة أم درمان العربية- للدكتور / كمال إبراهيم بدويرسالة دكتوراه- بدار العلوم- قسم اللغة العربية ع ع أم. اس-دراسـات نقديـة في النحو العربـي - للدكتور عبدالرحمن عحم أيـوب- مكتبـة

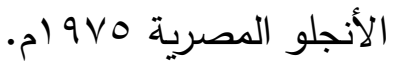




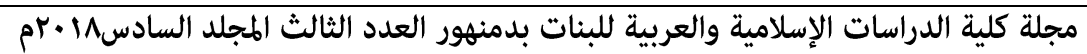
ץ"-دلائل الإعجاز - لعبدالقاهر الجرجاني - دار المعرفة- بيروت- لبنان. سب-الربط بين الجمل في اللغة العربية المعاصرة- دكتور / حمح حسن عبدالعزيز دار الفكر العربي. ع -سر الفصاحة- تحقيق: على فودة- طץ- الخانجي 999 ام. هب-مسـند أبـو داود- تحقيق: حمحـ محي الدين عبدالحميـد- المكتبـة العصـريةصيدا. بس-شرح ابن عقيل - المكتبة العصرية- صيدا- بيروت.

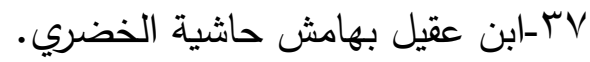

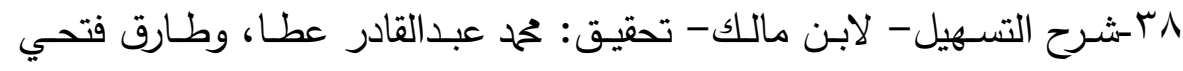
السيد- دار الكتب العلمية- بيروت- لبنان.

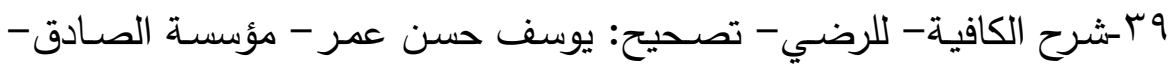
تهران.

• ع شـرح الكافيـة الثـافية- لابـن مالـك- تحقيـق: د/ عبـدالمنعم هريـدي- دار المأمون للتراث- مكة المكرمة.

اء -شواهد التوضيح والتصحيح لمشكلات الجامع الصحيح لابن مالك- تحقيق: محمد فؤاد عبدالباقي - دار العروبة.

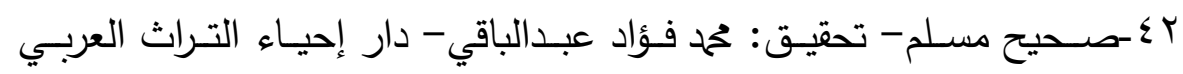
بيروت.

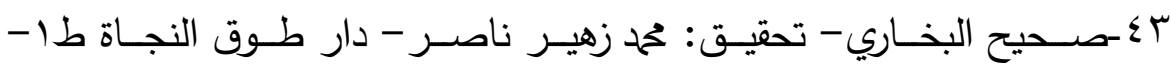

$$
\text { . } 1 \leqslant Y r
$$

ع ـ-عدة السالك إلى تحقيق أوضح المسالك- لمحي الدين عبدالحميد.

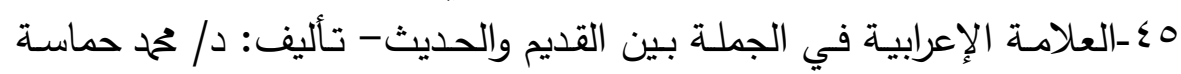
عبداللطيف- دار العلوم.

جـ -علم اللغـة - دي سوسـير - ترجمـة مالك المطلب- بيــ الموصـل للطباعـة

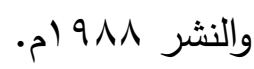

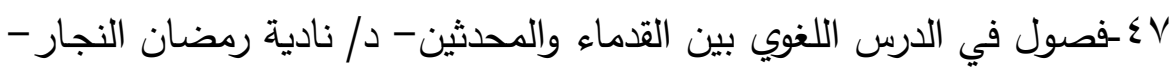
مراجعة: د/ عبده الراجحي، طب- ج ، . . بم، دار الوفاء. 


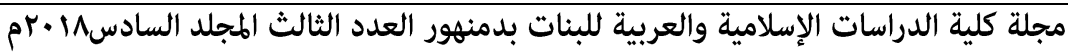

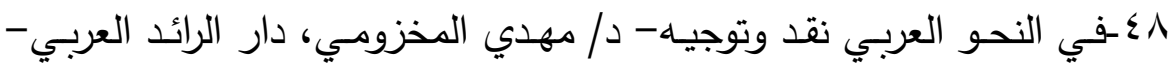
بيروت- لبنان، طب، 919 أم.

9 §-القـاموس المحيط- للفيروزآبـادي - مراجعـة أنس خحمد الثـامي وغيـره- دار الحديث - القاهرة.

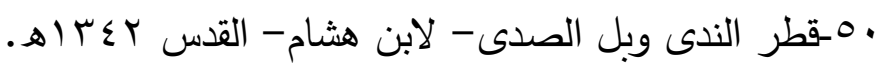
أ0ـالكافيـة مـن خـلال شـرح الكافيـة للرضـي - تحقيـق : يوسـف حسـن عمـر -

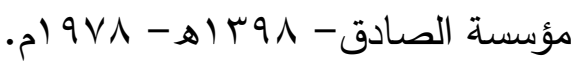
ro-الكتاب- لسيبويه- تحقيق: عبدالسلام هارون- مكتبة الخانجي- القاهرة. كاهـلسان العرب- لابن منظور - طبعة دار المعارف.

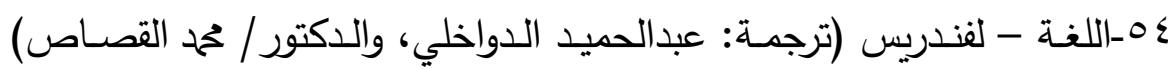
الأنجلو المصريـة.

00-اللغة العربية معناها ومبناها- د/ تمام حسان - دار الثقافة، طاه ع9 9 (م. 01-المحتسب- لابن جني- تحقيق: على النجدي ناصف وآخرون- المجلس

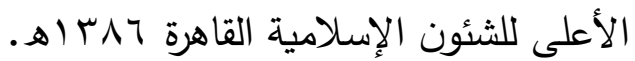
oV-مدخل إلى دراسة الجملة العربية- للدكتور / محمود أحمد نحلة- دار المعرفة

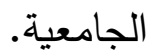

101-المرتجل- لابن الخشاب- تحقيق: د/ على حيدر، دمشق بـو ام.

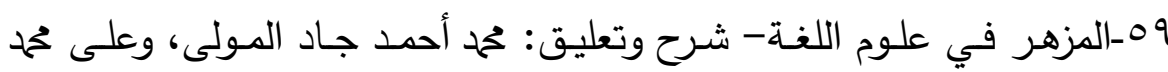
البجاوي وحمد أبو الفضل إبراهيم- دار الحرم للتراث. • 7-معاني القرآن - للفراء - تحقيق: عحمد على النجار - الدار المصسرية، وأخرى إنى تحقيق: على حيدر - دمشق rس 9 ام. ال7-مغني اللبيب عن كتب الأعاريب- لابن هشام الأنصساري- تحقيق: محي الدين عبدالحميد- طبعـة على صـبيح. وأخرى تحقيق: حنـا الفـاخوري- دار

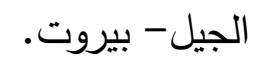

r r س7 -المفصل للزمخشري من خلال شرح المفصل - لابن يعيش - مكتبة المتنبي-

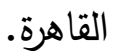




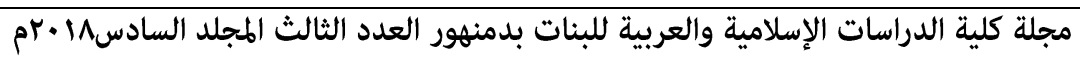

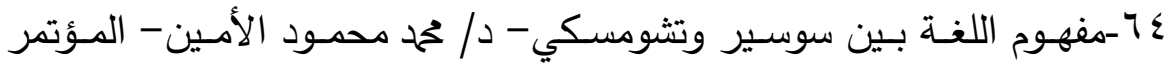
الدولي الثالث للغة العربية تحت عنوان الاستثمار في اللغة العربية ومستقبلها

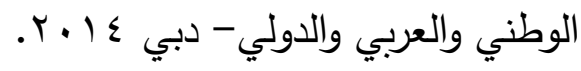

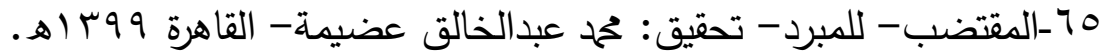
77-مقدمة ابن خلدون - تحقيق: د/ عبدالواحد وافي طس، دار النهضـة المصرية - ค) $9 \vee 9$

7V-مقدمة لدراسـة علم اللغـة- طا - دار المعرفة الجامعية 999 ام- د/ حلمي خليل.

1 1 -من أسرار اللغة- د/ إبراهيم أنيس - مكتبة نهضة مصر - الأنجلو المصرية. 99 -من أسس علم اللغة- د/ حمد حبلص - ط دار الثقافة العربية 999 ام.

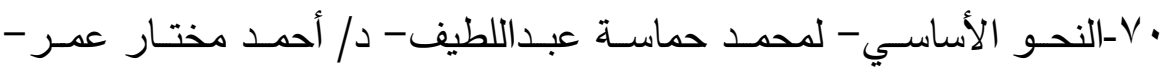
مصطفى النحاس زهران بr ع اهـ - ه . . بم- دار الفكر العربي.

الالالحو العربي بين القديم- مقارنة وتحليل - د/ عبدالله أحمد بن أحمد حمد.  مطبعة السعادة.

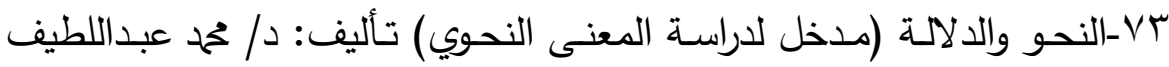

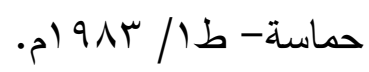
ع V-نظريـة تشومسكي اللغويـة- لتشومسكي - ترجمـة د/ حلمي خليـل - ط دار المعرفة الجامعية- 910 (م. ه V-هـع الهوامـع شـرح جمـع الجوامـع - للسـيوطي - تحقيق: د/ عبدالعال سـالم

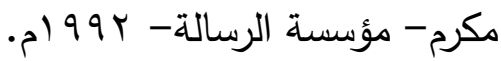


الإسناد والجملة العربيةبين القدامى والهددثين دراسة تحليلية هقارنة )

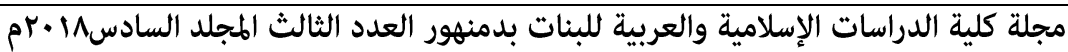

\section{فهرس الآيات القرآنية}

\begin{tabular}{|c|c|c|c|}
\hline رقم الصفهة & رقم الآية & الآية & السمورة \\
\hline$\varepsilon 9 \varepsilon$ & r & 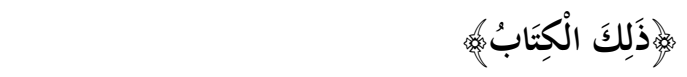 & \multirow{14}{*}{ البقرة } \\
\hline$\leq 9 \leq$ & 0 & 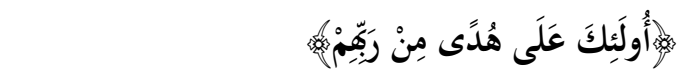 & \\
\hline$\varepsilon Y \nearrow$ & 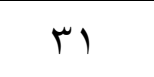 & 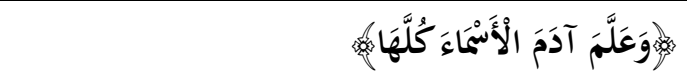 & \\
\hline$\varepsilon 9 \wedge$ & $7 \leq$ & 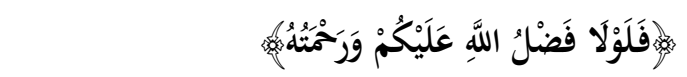 & \\
\hline ory & $1 \leqslant Y$ & 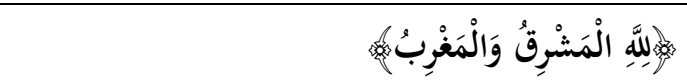 & \\
\hline ory & 101 & مإِ & \\
\hline ory & 107 & 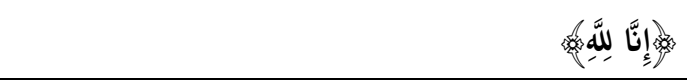 & \\
\hline דry & 101 & 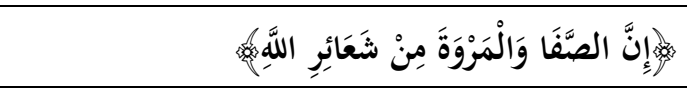 & \\
\hline ory & IVA & 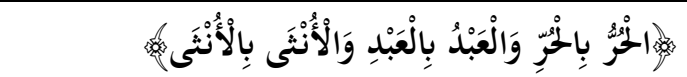 & \\
\hline & $1 \vee 9$ & 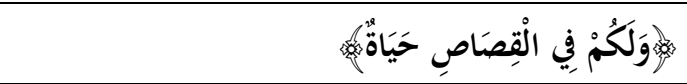 & \\
\hline ory & YI & 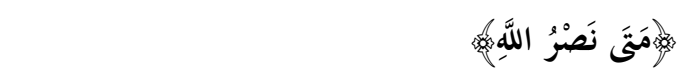 & \\
\hline 纟Tr & Trt & 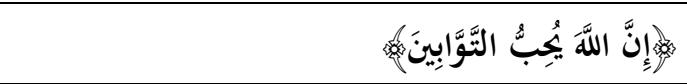 & \\
\hline 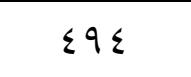 & ror & 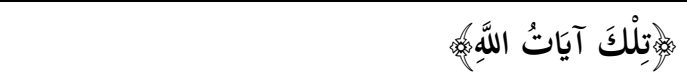 & \\
\hline$\leq 9 \leq$ & YYI & 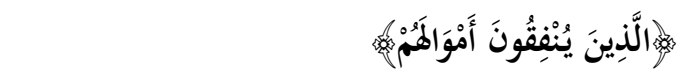 & \\
\hline or. & $1 \leqslant \varepsilon$ & 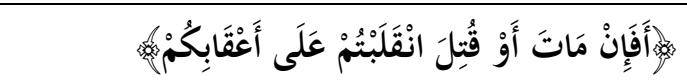 & آل عمران \\
\hline or. & V^ & 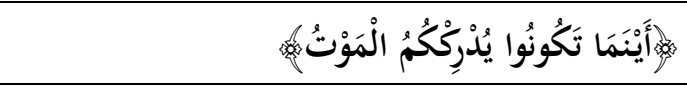 & \multirow[t]{2}{*}{$\underline{\text { النساء }}$} \\
\hline $0 . \varepsilon$ & ITE & 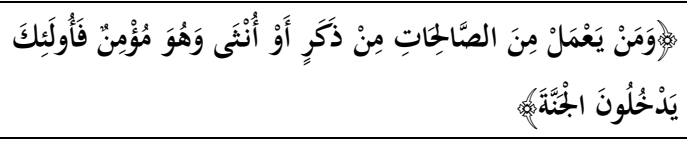 & \\
\hline $0 \leqslant Y$ & r & 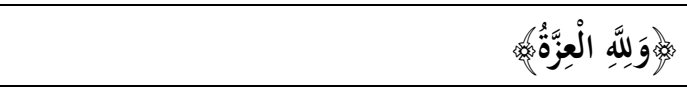 & \multirow[t]{3}{*}{ المائدة } \\
\hline 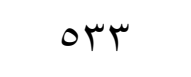 & 90 & 番 & \\
\hline or. & r.. & 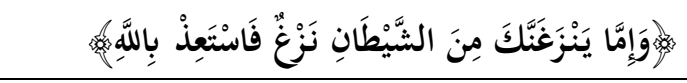 & \\
\hline ory & 09 & 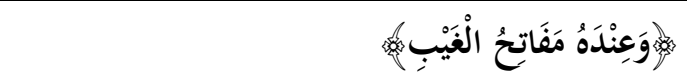 & الأنعام \\
\hline
\end{tabular}




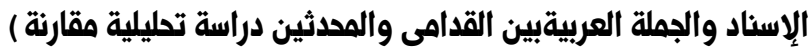

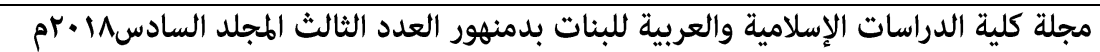

\begin{tabular}{|c|c|c|c|}
\hline رقم الصفمة & رقم الآية & الآية & السـورة \\
\hline $0 . \varepsilon$ & I ro & 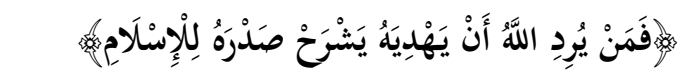 & \\
\hline $0 . \varepsilon$ & 1.7 & 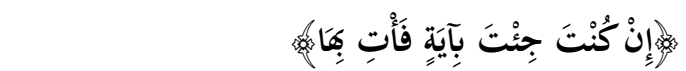 & \multirow[t]{3}{*}{ الأعراف } \\
\hline $0 . \varepsilon$ & $1 \leq r$ & 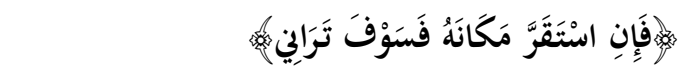 & \\
\hline ory & $1 \wedge$ & 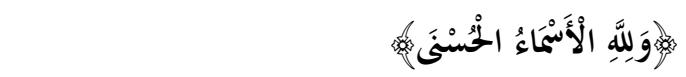 & \\
\hline$\leqslant \wedge 0$ & 9 & 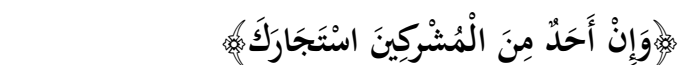 & \multirow[t]{2}{*}{ التوبة } \\
\hline 0.0 & $r t$ & 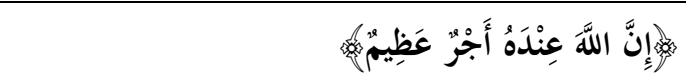 & \\
\hline 0.0 & $\leqslant 7$ & 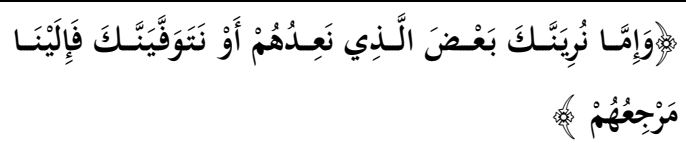 & يونس \\
\hline$\varepsilon 9 \varepsilon$ & 9. & 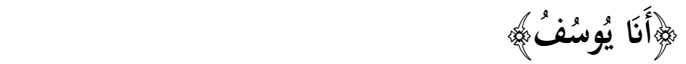 & يوسف \\
\hline $0 \leqslant \varepsilon$ & 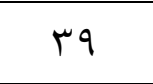 & 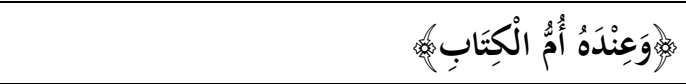 & الرعد - الرد \\
\hline 0.0 & 1. & 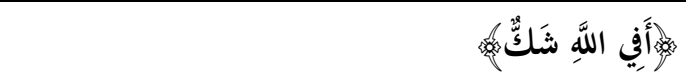 & \multirow[t]{2}{*}{ إبراهيمي } \\
\hline ort & 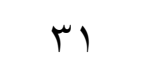 & 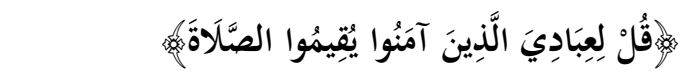 & \\
\hline or. & 11. & 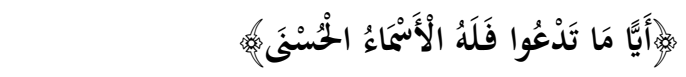 & 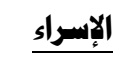 \\
\hline ort & $\checkmark V$ & 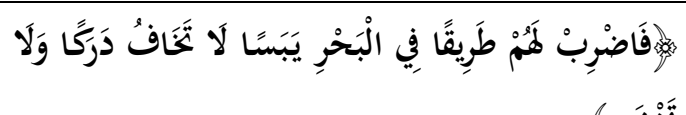 & \multirow[t]{3}{*}{ طه } \\
\hline ו וTO & $\wedge 1$ & 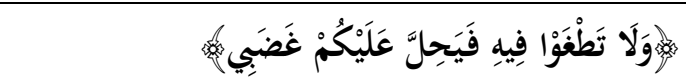 & \\
\hline 0.0 & rr| & 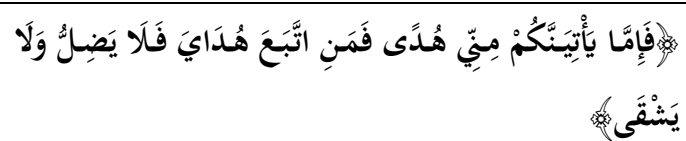 & \\
\hline or. & re & 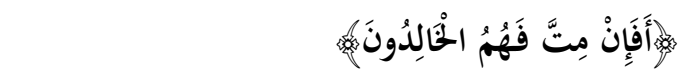 & الأنبياء \\
\hline ory & $79-71$ & 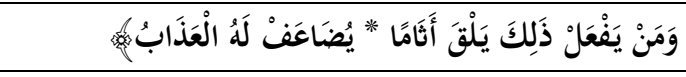 & الفرقان \\
\hline ty & $\Sigma \curlywedge$ & 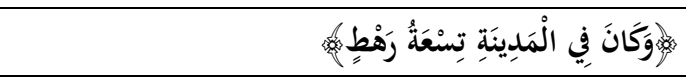 & النسمل \\
\hline $0 \leq 7$ & $r$. & 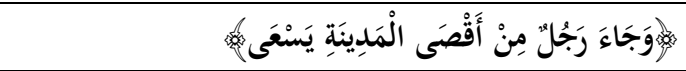 & القصص \\
\hline צחס & r & 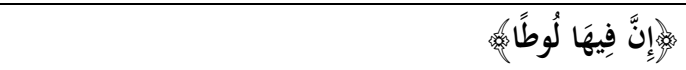 & العنكبوت \\
\hline
\end{tabular}




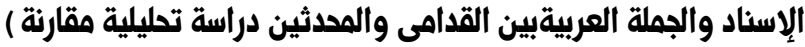

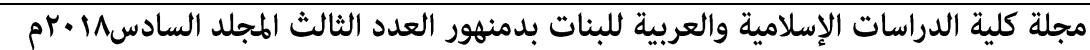

\begin{tabular}{|c|c|c|c|}
\hline رقم الصفية & رقم الآية & الآية & المسورة \\
\hline 0.0 & $\mathrm{~V} \cdot$ & 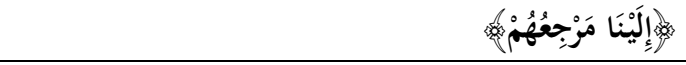 & يس - le \\
\hline ty & $\varepsilon V$ & 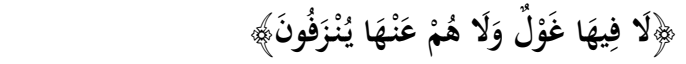 & | الصافات \\
\hline Mrt & $r$. & 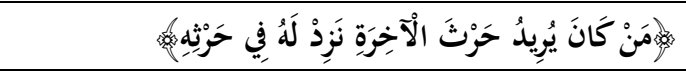 & الشورى \\
\hline $0 \leq \leqslant$ & r & 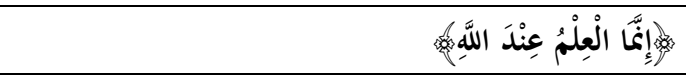 & الأحقاف \\
\hline $0 \leq \leqslant$ & $\varepsilon$ & 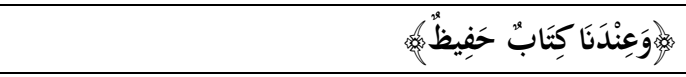 & \multirow{2}{*}{$\underline{\theta}$} \\
\hline $0 \leqslant Y$ & ro & 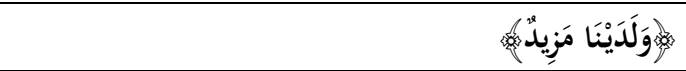 & \\
\hline$\varepsilon \wedge V$ & 09 & 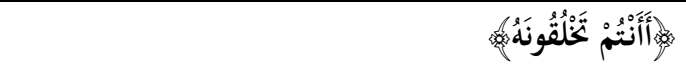 & الواقعة \\
\hline $0 \leqslant \varepsilon$ & 19 & 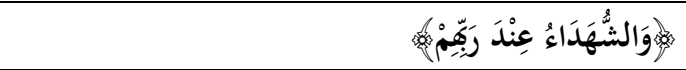 & الحديد \\
\hline $0 \leqslant Y$ & $\wedge$ & 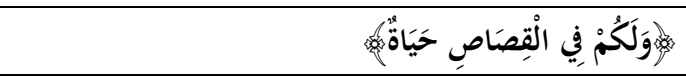 & \multirow[t]{2}{*}{ المنافقون } \\
\hline ort & 1. & 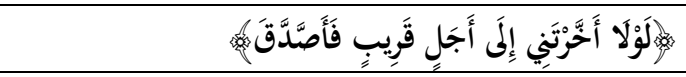 & \\
\hline$\varepsilon \wedge \vee$ & 7 & 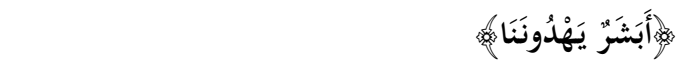 & التغابن \\
\hline$\varepsilon \wedge \wedge$ & rT & 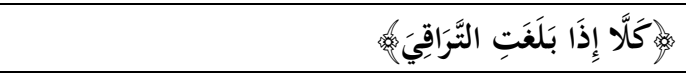 & القياهة \\
\hline$\leqslant 7 \wedge$ & r & 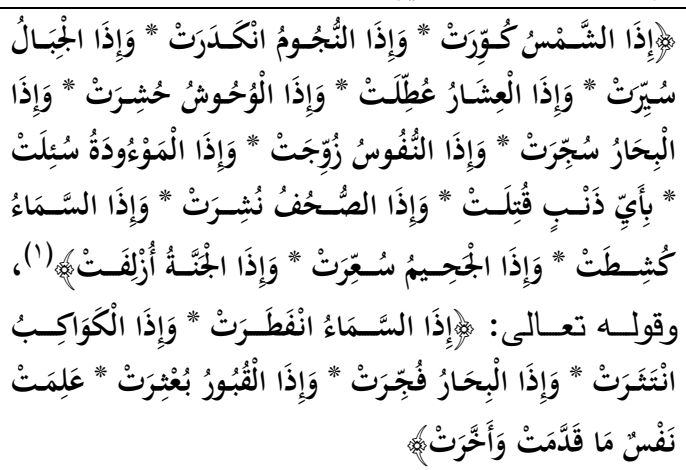 & التكوير \\
\hline $0 \wedge T$ & $0-1$ & 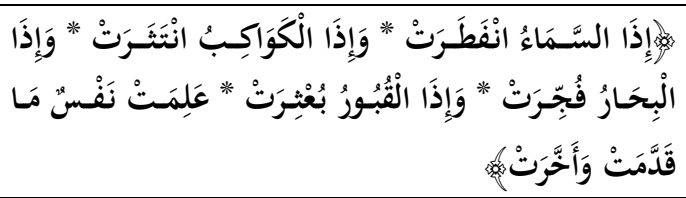 & الانفططار \\
\hline$\varepsilon \wedge 0$ & 1 & 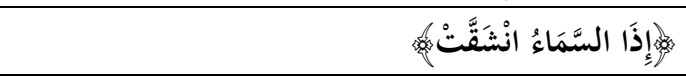 & الانشقاق \\
\hline$\varepsilon \wedge \vee$ & 1 & 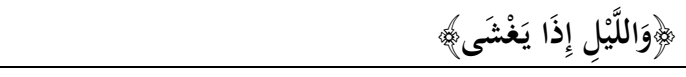 & الليل \\
\hline
\end{tabular}

(1) الآيات من ا- با من سورة التكوير · 


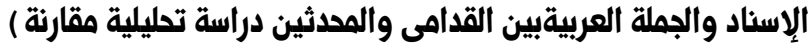

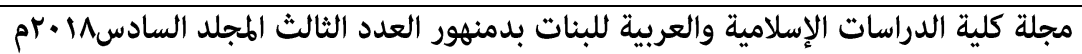

\begin{tabular}{|c|c|c|}
\hline \multicolumn{3}{|c|}{ فهرس الأحاديث } \\
\hline رقم الصفحة & الحديث & م \\
\hline$\varepsilon \leqslant \wedge$ & ״إنما الأعمال بالنيات وإنما لكل امرى\{ ما نوى《 & 1 \\
\hline$\varepsilon \wedge \wedge$ & ״لا يزنـي الزانـي حين يزنـي وهـو مـؤمن، ولا & r \\
\hline $0 \leqslant 9$ & أحي والداك & r \\
\hline 00 . & أو مخرجيَّ هم & $\varepsilon$ \\
\hline
\end{tabular}

\section{فهرس الأقوال والأمثال}

\begin{tabular}{|c|c|c|}
\hline رقم الصفحة & القول & م \\
\hline$\leqslant 91$ & كل رجل وضيعته & 1 \\
\hline$\varepsilon 9 \wedge$ & ضربي زبد قائما & r \\
\hline$\leqslant 9 \wedge$ & سمحُ وطاعةٌّ & 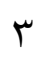 \\
\hline
\end{tabular}


الإسناد والجملة العربيةبين القدامى والهددثين دراسة تحليلية مقارنة )

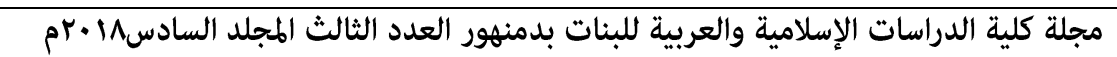

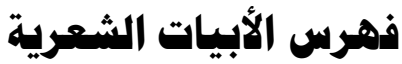

\begin{tabular}{|c|c|c|c|c|}
\hline الصفحة & القائل & البحر & القافية & البيت \\
\hline וT & & & الباء & وإذى الذبي يعطي خصاصت الرغائب فارغ الغنى \\
\hline$\varepsilon \vee 7$ & الزباء بنت عمر بن الضرب & رجز & الدال & 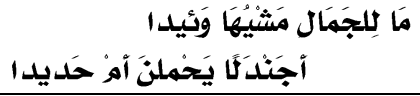 \\
\hline or. & عنترة & الوافر & الراء & متى ما تلقني فردين ترجف \\
\hline$\varepsilon \varepsilon V$ & & & القاف & 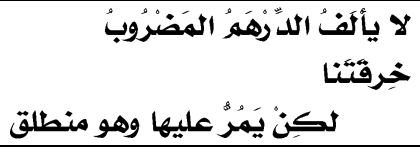 \\
\hline or. & & الطويل & اللام & إذا النعجت الأدماء كانت بقفرة التعدان بهان الريح تنزل \\
\hline וT & علقة & الرمل & اللام & لو يشأ طاربه ذوميعت \\
\hline ו & الفراء & الكامل & اللام & استغنى ما أغناك ربك رإك بالغنى فتجمل \\
\hline$\varepsilon \varepsilon r$ & عقيل بن أبي طالب & 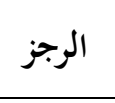 & اللام & أنت تكون ماجد نبيل \\
\hline OrT & زهير بن أبي سلمى & البسيط & الميم & وإن اتاه خليل يوه مسأنت \\
\hline OrV & & البسيط & الميم & 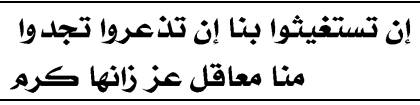 \\
\hline 00. & & الحفيف & الميم & غير لاهٍ عداك فاطرح اللهو \\
\hline 001 & أبو نواس & المديد & النون & غير مأسوفٍ على زمن ينقضي بالهم والحزن \\
\hline
\end{tabular}




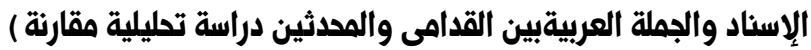

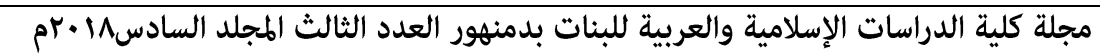

\begin{tabular}{|c|c|}
\hline الصفحة & 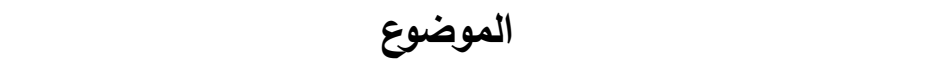 \\
\hline LYr & \\
\hline$\varepsilon r \uparrow$ & \\
\hline 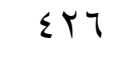 & يف اللغة. \\
\hline$\varepsilon r \wedge$ & r- الفرق بين اللغة والجملة (الكلام). \\
\hline$\varepsilon r$. & في الموروث النحوي والعلاقة بينها وبين الكلام. \\
\hline 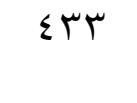 & د في الموروث النحوي، وعلاقته بالجملة. \\
\hline$\leqslant \varepsilon r$ & الإسناد في النحو الحديث وعلاقته بالجملة. \\
\hline$\leqslant 00$ & أثر الإسناد في النحو الحديث على التراكيب العربية في الميزان. \\
\hline$\leqslant 00$ & المبـحث الأول: أثره على التقسيم الثنائي القديم. \\
\hline 0.4 & المبـحث الثاذي: أثره على الجملة الشرطية والجملة الظرفية. \\
\hline $0 \leqslant 7$ & المبحث الثالث: أثره على التركيب الوصفي. \\
\hline 001 & الخاتمة \\
\hline $0 \vee 7$ & ثبـت الهادر والراجع. \\
\hline $0 \wedge 1$ & \\
\hline
\end{tabular}

